






\title{
d|
}

\author{
BETNG \\ A DESCRIPTION LI \\ OF THE

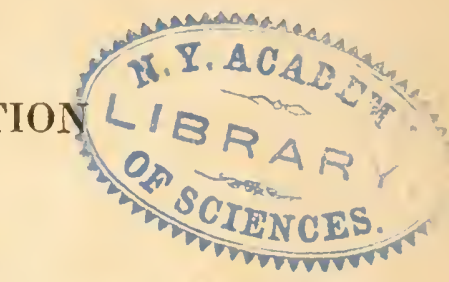

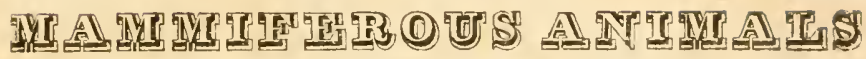

INIIABITING NORTH AMERICA.

\begin{abstract}
and
BY RICHARD HARLAN, M. D.

PROFESOH OF COMPARATIVE ANATOMY TO THE PHILADELPHA MUSEUM ; MEMEER OF THE AMERICAN PHILOSOPHICAL SOCIETY; OF THE ACADEMY OF NATURAL SCIENCES OF PHILADELPHIA; CORIESPONDING MEMBER OF THE LYCEUM OF NATURAL HISTORY OF NEW YORK, \&c. \&c.
\end{abstract}

"The manor of living nature is so ample, that all may be allowed to sport on it freely; the most jealous proprietor cannot entertain any apprehension that the game will be exhausted, or even perceptibly thínned."

PHIL.ADELPHIA :

PUBIISHED BY ANTHONY FINLEY.

J. HAIRING, PRINTEI. 


$$
a 075
$$


I'O

JAMHS I. DEKAY, M. D.

UEMBER OF THE IYCEUM OF NATURAL HISTORY OF NEW YORK ; OF THF ROYAL MEDICAL SOCIETY OF EDINBURGH ; CORPESPONDING MEMBER OF THE ACADEMY OF NATURAL SCIENCES OF PHILADELPLA, \&c. \&c.

\section{THIS ATTEMPT}

TO ILLUSTRATE THF NATURAL HITORY

$$
\text { OF }
$$

NORTH AMERICA,

IS MOST RESPECTFULLY INSCRIBED

HE IUS MUCH OBLICED FRIEND

THE AUTHIOR. 



\section{INTRODUCTION.}

I HAVE engaged in the present undertaking with a full conviction of its absolute necessity, and am very sensible of the difficulties attending the complete attainment of its aim.

A work having for its object the illustration of the natural history of our country, cannot fail to prove interesting, and has long been a desideratum to naturalists. However unqualified for the task, I have nevertheless found ample room for additions, alterations and improvements. On the utility of the undertaking it will be unnecessary to insist, when, on referring to the latest authoritics who have treated of this subject, we are strucls with the confusion, the errors and the deficiences'which still prevail. In the very latest work, Desmarest's Mammalogie, published in the year 1S20, which professes to describe all the species of Mammalia, hitherto known, the number inhabiting North America, is limited to one hundred species. Of these many are described as uncertain, and his accounts of the manners and habits of most of them, are at best deficient.

These remarks are not intended to imply any reflection on the author, whose work is really one of great merit. I have found his synonymes most generally correct, and his lescriptions for the most part extremely minute and accurate. The errors are such as are necessarily connected with the nature of the rescarch; the deficiency of materials; 
the want of accurate information, \&c.* Scarcely indeed, has he had it in his power to quote a single American author, who, inhabiting the same regions with the animals, which are the objects of his research, would alone be capable of obtaining precise information concerning them. We may further remark, that since the publication of Mr. Desmarest's work, many discoveries have been macle, and much valuable information has been collected in this department of natural history, the high rank and importance of which, beginning to be perceived by a liberal public, individuals, who have hitherto confinerl their investigations more particularly to other branches, have now turned their attention to this. Urged by similar motives, our common guardians and cnlightened statesmen, have organized exploring expeditions, which under the command of a most judicious officer, accompanied by men of science, have made such discoverics in almost every department of natural history, as confer an invaluable boon upon their country. The naturalists who accompanied Major Long's expedition to the Rocky Mountains, have described twelve new species of quadrupeds, besides fixing the characters, and detailing the labits of many others hitherto imperfectly known.

To Mr. Sabine's appendix to Captain Parry's and Captain Franklin's expeditions, we have been indebted for much valuable information, as well as for the description of several new species.

* Mr. Desmarest, in his advertisement to the second part of his "Mammalogice," p. 7, limits the number of mammalia inhabiting North America, to fifty-four species : as this statement does not in any legree correspond with his descriptions, we presume he has permitted a typographical error, of great importance, to escape his notice. We have enumerated from lis work one hundred species, as inhabiting North America; the descriptions of :bout fifty of these having been found very accurate, are accordingly translated with rery little alteration. 
Mr. Rafinesque, professor in the Transylvania University, in the State of Kentucky, has described, or rather inclieated, a great variety of animals; but his insulated situation, and almost utter ignorance of the labours of other naturalists, have seduced him into grievous errors, and occasioned much confusion in natural history. It is possible, that some of his animals may be new species, but from the looseness of his imperfect descriptions, we have been obliged to reject them in almost every instance.

I should commit an act of injustice towards the most valuable of friends, were I to pass sub silentio, the reiterated proofs of kindness I have received from Dr. Dekay of New York. The unusual interest he has displayed in the success of this work; the important references he has afforded, and the valuable hints he has suggested, entitle him to my warmest aeknowledgments.

By collecting together all the detached observations published in various journals, aided by personal observation, when this was in our power, we have been able to distinguish with considerable accuracy, one hundred and forty-seven species, as inhabiting North America.* Of these,

* Commencing at the most southern boundary of the United States, and not including the animals of Mexico, many of which are as yet but imperfectly known. Hernandez and Clavigero in their account of the natural history of this country, have noticed a number of animals, some of which are no doubt fabulous. The following is a list of such as inhabit Mexico, according to Clavigero :-

" Wild cats; bears; wolves; foxes; stags; buck; wild goats; badgers; pole-cats; weasels; martins; squirrels; rabbits; hares; otters; rats; a species of apes, called mono by the Spaniards; peccari; zorillo; opossum; armadillo; techichi or alco; swizzero; saricovienne; tapir; cynocephala cercopitheca of Briss. ; ant-eater; coyoto or cojotl and porcupine."

of these animals, some are common to South America and Mexico; 
several are entirely new, and not before described: eleven species are fossil, and no longer exist in a living state, in this, or any other country; many were imperfectly noticed, or erroneously deseribed; others mercly indicated. In several instanees species, and in three or four cases, genera, have been confounded.

With regard to the distribution of the North American mammalia, they are thus divided-119 are Quadrupeds, 28 Cetaeea.

To the order Primates belong, - $\quad$ - 1 species.

\begin{tabular}{|c|c|c|c|c|c|}
\hline Carnivora, - & & - & & - & \\
\hline Glires, - & - & & - & & \\
\hline Edentata, & - & - & & - & \\
\hline Pachydermata, & & & - & & - \\
\hline Ruminantia, & & - & & - & \\
\hline Cetacea, - & - & & - & & - \\
\hline
\end{tabular}

Twenty-five speeies are common to both Continents, without including the ectaeeous animals, viz:-

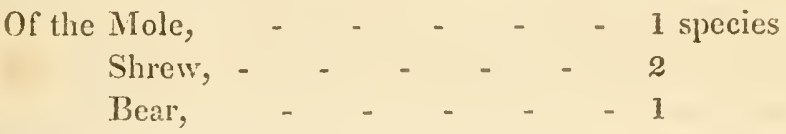

whers to Mexico and the United States, a few species only being peculiar to Mexico, viz:-Cebus apella; phyllostoma spectrum; potos caudirolvula; canis mexicanus; felis mitis; felis mexicanus; didelphis cancrivora; didelphis cayopollin. (Hernand.) If we add these to the number deseribed in the following pages, it will afford a sum total of 155 species as inhabiting North America, a computation which no doubt falls far. short of the actual number. 


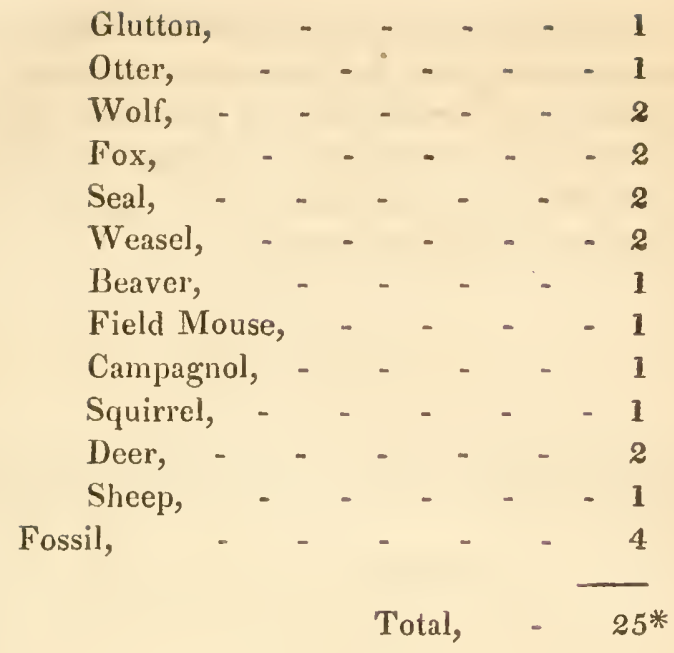

The present publication may be viewed rather as an outline, or foundation of one, in many respects more extensive and more perfect. Sensible of the imperfections of this, his first effort, the author has the consolation of knowing, that it is the only attempt of the kind which has been made by an American naturalist, and flatters himself, that he would be foremost to hail with pleasure, and to read with delight, a more successful production from any of his fellow labourers in this field of science. The manor is inexhaustible and opens to our view an immense intellectual horizon.

We cnjoy the most pleasing prospect, in the present rapid progress towards a complete illustration of the natural

* Where any doubt exists, or further information is requested, concerning any species, the same is signified by being marked with an as. terisk. * 
history of our country. 'The most zealous, able and inde fatigable naturalists, are at this moment engaged in and have nearly perfected the departments of American ornitholo$s y$, conchology and entomology. An equal degree of attention bestowed on herpetology is alone requisite to coms. plete the circle of American zoology. 


\section{FAUNA AMERICANA:}

BEING

\section{A DESCRIPTION}

OF THE

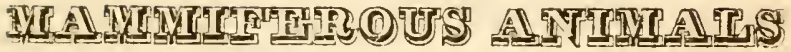

INHABITING NORTH AMERICA.

\section{Order PRTMA'TES.}

Characters. Four extremities, the inferior of which are proper for progression, the superion terminated by hands ; fingers furnished with nails ; three kinds of teeth ; body organized for the vertical station, two pectoral mammæ.

\section{Gemes....1. Номо.}

CHARACTERS.

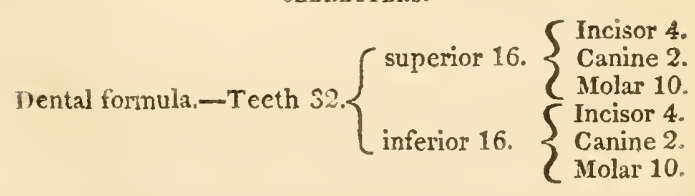

'l'eeth forming a regular, unbroken series; the line formed by the surface of the xpper series 
slightly convex; the line formed by the surface of the lower series slightly concave. Incisors proceed in a direction more or less vertical with the maxillary bones; the two middle ones of the upper jaw are broadest; inferior incisors nearly equal, the two exterior rather broadest; canines in either jaw, not projecting, with their summits more or less obtusely triangular; the two first molars in either jaw are the smallest, their crowns furnished with two blunt tubercles, one internal, the other external; the three remaining molars nearly equal, those of the upper jaw have the crowns furnished with three tubercles; two on the outer, one on the inner side; the crowns of the inferior, with generally four tubercles, two on the outer, two on the inner side.

Superior extremities terminated by a hand; an organ eminently prehensile, and susceptible from its structure of a greater variety of motions than that of any other animal; five-fingered; thumb possessing the power of motion in all directions, independent of the fingers; fore-arm shorter than the arm.

Inferior extremities constructed for the upright posture only; the feet at right angles with the legs; five toes, with broad flat nails; sole, more or less arched, the weight of the body being supported chiefly. by the os calcis, and extremities of the tarsal bones, the posterior borders of the former resting firm and flat upon the ground. 
Body for the most part naked, and defenceless, those parts being most hairy, which in animals are most bare, viz. the axillæ and pubes. Finally, Man is the only being that worships God, and anticipates immortality.

\section{Species....1. Hono Sapiens.}

Characters of the species, are those peculiar to the genus.

Inhabit all parts of the earth, omnivorous, disputing for territory; uniting together for the express purpose of destroying their own species.

\section{Varieties....1. American Race.}

Char. Face rather large, features well pronounced; nose sufficiently projecting, frequently aquiline; hair black, strong, glossy and dense on the head, rather flattened, a transverse section being rather more oval than a section of the hair of the Caucasian, seldom becomes gray; beard rather sparse by nature.

Facial angle rather oblique, averaging about 80 ; the lower jaw is large and robust; teeth very strong, with broad crowns; chin well formed; lips rather tumid; cheek bones prominent, but rounled; the expression of the countenance is austere, never vacant, sometimes ferocious. The orbits of the eyes are larger, and more nearly quadrangular than those of the Mongolian; the transverse diameter of the American is one inch sif-tenths, 
the vertical diameter one inch five-tenths; transverse diameter of the Mongolian, in a skult which I possess, from Kamtschatka, one inch sixtenths, vertical diameter of the same, one inch two-tenths. The feet, though exceedingly well formed, are wider immediately above the toes in the American, than in the Caucasian, which is due probably to the absence of pressure in the former.

By European authors, the aborigines of America have been placed as the fourth in number, in the series of the varieties of the human race; but in proportion as their history is investigated and their character more fully developed, we shall find them to rise in our estimation. In a physical or moral and intellectual point of view, if we take into consideration their limited means for improve. ment, I am convinced we shall find little to boast or to hope for on the score of superiority. Destitute of all the comforts and conveniences of civilized life, exposed to the severest endurance of cold, fatigue and hunger, the American savage has displayed energies of mind, and qualities of the heart, which would not derogate from the character of a Socrates or a Solon. The Indian by nature is hospitable, eloquent, noble, generous and brave; their utter contempt of danger and death, their perfect self-possession, has been too frequently construed by superficial observers, as apathy, coldness, or indifference. On the contrary, numerous examples testify, that they are not 
wanting in heroic sympathy; though the warrior seldom smiles, perhaps never laughs, there are occasions, when he thinks it not unmanly to shed a tear.

As far as my observations extend, I should be inclined to rank the $\mathcal{N}$ orth American native, as second to the Caucasian variety.

They inhabit all America, excepting probably the Esquimaux, which possess stronger affinities to the Mongolian than the others.

\section{Order CARNIVORA.}

Char. The incisors, canine, and molars, most generally adapted for animal food.

Four extremities, the anterior of which are never terminated by hands, or a thumb separate. from the fingers, and opposable; mammæ varying in number.

Articulation of the lower jaw directed transversely, not admitting any lateral motion.

Orbits not separate from the temporal fossæ.

Stomach simple, membranous ; intestines short.

Nourishment according to the species, flesh, fresh or corrupted, insects, eggs, and even vegetable substances. Inhabit all the earth, which is habitable for quadrupeds.

\section{Family Cheiroptera.}

Char. General form disposed for flight; inci- 
sors in very variable numbers; canines more or less strong; crowns of the molars sometimes tuberculated, sometimes grooved lengthwise; a fold of skin extended between the four extremities, and between the fore-fingers.

Two pectoral mammæ; penis of the male free; powerful clavicles, scapulæ broad; fore-arm not susceptible of pronation or supination.

\section{Tribe, Vespertilio.}

Char. Fore-fingers excessively elongated, and supporting a very fine membrane, with the thumb only separate, not opposable.

Incisors, canine, and molars easily distinguishable by their forms; membrane naked both above and below.

\section{Genus.}

Rhinopoma, Geoff.

Vespertilio, Belon, Brunich.

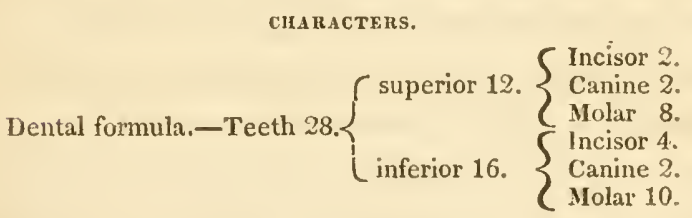

Superior incisors separate from each other; nose long, conical, truncated at the extremity, and surmounted by a small membranous fold; nostrils narrow, transverse and operculated, broad and concave above; ears large, approximate and fall- 
ing over the face; auriculum exterior: Interfemoral membrane narrow, and terminating in a square border; tail long, enveloped at its base.

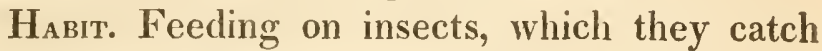
during the evening, on the wing.

Inhabit Egypt and the United States of America.

\section{Species.}

\section{Rhinopoma caroliniensis, Geoff.}

Colour of the hair brown; tail long and thick.

Dimensions. Total length two inches; length of the tail one inch six lines; spread of the wings eight inches.

Description. Ears moderate, nearly triangular; the two superior incisors simple, directed inwards; the four inferior incisors bilobate, and crowded in between the canines, which are, nevertheless, not very strong, and are in contact only at their base; colour of the hair, brown; membranes obscure; interfemoral membrane envelops one half the tail. Inhabits South Carolina, (according to Geoff.)

\section{Genus.}

Vespertilio, Linn. Erxleb. Briss. Pall. Shreb. Cuv. Geoff. Illig.

Plecotus, Geoff: 
CHARACTERS.

1. Vespertilio, Linn.

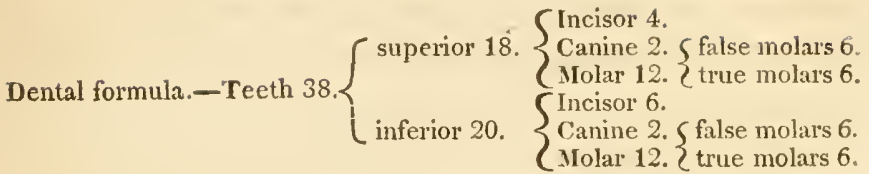

2. Vespertilio, Desm.

Dental formula. -32 or 36 teeth. $\left\{\begin{array}{l}\text { superior } 14 \text { or } 16 . \\ \text { inferior } 18 \text { or } 20 . \\ \begin{array}{l}\text { Incisor } 4 . \\ \text { Canine } 2 . \\ \text { Molar } 8 \text { or } 10\end{array} \\ \begin{array}{l}\text { Incisor } 6 . \\ \text { Canine } 2 . \\ \text { Molar } 10 \text { ol } 12 .\end{array}\end{array}\right.$

Superior incisors separated into pairs, cylindrical and pointed; inferior approximate with bilobate edges inclined and directed forwards.

Canines moderate, and not touching at base.

Anterior molars simply conical; the posterior with broad crowns and tuberculated points; the inferior grooved on the sides; the superior twice as large, having an oblique cutting crown.

Nose not foliated, nor grooved, nor wrinkled, nor operculated over the nostrils.

Lower lip simple; tongue snooth, not protractile.

Ears more or less large, with an auriculum.

Wing-membranes very extensive, and measuring in spread, four or five times the total length of the body.

Index finger having only one phalanx; middle finger three, annular and little finger two. 
Tail entirely comprised in the interfemoral membrane, and very extensive; fur soft and thick.

Sebaceous glands beneath the skin of the face, affecting different forms and dimensions, according to the species.

Habiт. Nocturnal; hibernating in caves, suspending themselves from the sides of vaults, caverns, \&c. by their hind legs, the head downwards, and the body enveloped by the wing membranes; feeding on insects which they catch during the crepusculum; producing generally only one young at a birth; flying easily and silently. The organ of hearing is acute, that of touch very perfect.

Inlabit the temperate regions of both continents.

\section{Species.}

1. Vespertilio caroliniensis, Geoff. Ann. Mus. d'hist. Nat. tom. 8. pl. 47.

Char. Essent. Ears oblong, of the size of the head, in part hairy; auriculum demi-cordiform; colour above chesnut brown, beneath yellow.

Description. Ears of moderate size, without folds at the internal border, their external surface furnished witl fine hair on the first half; auriculum nearly cordiform; extreme point of the tail free; colour chesnut brown above, yellowish beneath, each hair being blackish-cinereous at base. Inhabit the neighbourhood of Charleston, South Carolina. 


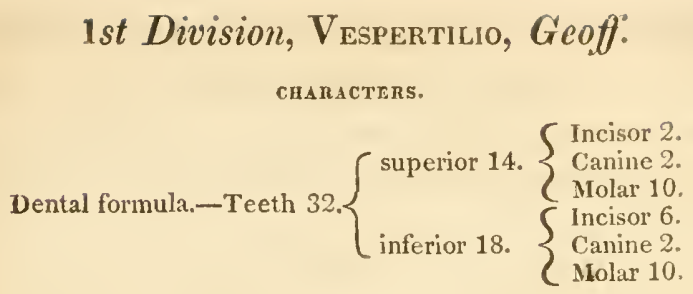

Superior incisors very separate from each other, and very near to each canine; four false molars, six true in each jaw; the anomalous false molar has a small tubercle placed at the internal border of the base of the canine. The species hitherto observed, are the Vespertilio lasiure, V. noveboracencis, V.paradoxus, and probably also the $\mathrm{V}$. pruinosus.

\section{Species.}

1. Vespertilio noveboracensis. New-York bat. Penn. Syn. p. 367, tab. 31, fig. 2. Linn. Gmel.

Char. Essent. Ears short and broad, rounded; tail wholly enveloped in the interfemoral membrane.

Dimensions. Total length two inches five-tenths; tail nearly two inches; spread of the wings more than ten inches.

Description. Nose short, pointed; body brown above, pale beneath; a white spot at the base of the wings.

Note. This species is one of the two on which Rafinesque has constructed his new genus "Ata. 
r.APHA," one of the characters of which is, "no incisors in either jaw!" Vid. prod. de Semiologie. Amer. Month. Mag.

Inhabit New York.

\section{Species.}

2. Vespertilio primosus, Say. Major Long's Expedition to the Rocky Mountains, vol. 1. p. 167.

Ears large, short, not so long as the head, hairy on the exterior side, more than half their length; tragus, very obtuse at tip, arcuated; canine teeth large, prominent; incisors one on each side, placed very near the canine, conical, almost on a line with it, and furnished with a small tubercle on its external base; nostrils distant; fur on the back, black brown at base, then pale brownish-yellow, then blackish, then white; towards the rump dark ferruginous; dull yellowish-white on the throat; wing-membrame, on the anterior lower margin, hairy ; interfemoral membrane, covered with fur ; length nearly four inches and a half.

Inhabits the Western States, and has been observed in Pennsylvania.

3. Vespertilio arquatus, Say. Long's Exp. (ut supra.)

Head large; ear's rather shorter than the head, wide, and at tip rounded, hairy at base; posterior edge with two slight obtuse emarginations; the anterior base distant from the eye ; tragus arcuat- 
ed, obtuse at tip ; interfemoral membrane naked, including the tail to one half the penultimate joint

Total length five inches; tail one inch and a half; expansion thirteen inches.

Inhabits the Western States.

Vespertilio subulatus, Say. Long's Exp. Vol. ii. p. 65. I believe this species to be merely a variety of the V.caroliniensis, (Greoff.) from which it differs slightly in colour, and in the form of the auriculum.*

\section{Genus.}

Taphozous, taphiens, Geoff.

Vespertilio, Schreb. Muller.

Saccopteryx, Illig.

CHARACTETS.

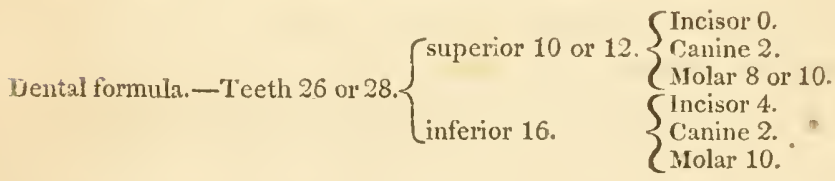

Nose not furnished with membranous folds, or operculi; superior lip very thick; ears of moderate size; tail composed of six vertebra, free above the membrane; interfemoral membrane extensive; posterior border triangular.

* It is to be regretted that the dental formula has been neglected in the descriptions of the two last species, which prevents us from arranging them in systematic order with certainty 
Inhabit both continents.

Species.

1. Taphozous rufus. Figured in Wilson's Ornithology, vol. vi. Red Bat of Pennsylvania. Philadelphia Museum.

Vespertilio rufus, Warden. Description of the United States, vol. v. page 608.

Char. Essent. Fur of a reddish cream colour: membranes of a dusky red; auriculi slender. rouncled at the extremity, and situated internally.

Dimensions. Total length four inches; tail as long as the body; spread of the wings twelve inches.

Description. General colour, bright iron gray : fur of a reddish cream colour at base, then strongly tinged with lake, and minutely tipped with white; ears scarcely half an inch long, with auriculi; nostrils somewhat tabular; eyes small; wings furnished with a single hook; interfemoral membrane triangular.

Habit. Similar to the other Vesperticio. The female has been known to manifest the strongest maternal affection; a young lad having taken two young bats of this species, was in the act of carrying them to the Museum at mid-day; being watched by the mother, she followed him through the streets, fluttering round the thoughtless urchin in whose grasp was centred all her hopes, 
and eventually settled on his bosom, preferring captivity to freedom, with loss of progeny.

\section{Family INSECTIVORA.}

Char. Essent. Feet short, armed with robust nails; hind feet always five-toed, resting on the anterior part of the sole; fore feet most generally five-toed; crowns of the molar teeth elevated into sharp tubercles; canine teeth sometimes very long, sometimes very short.

Number of incisors variable. Body covered with hair, or spines ; feeding on insects, roots, and fruits.

Inhabit the temperate climates of both continents.

1st Division. Two long incisors before, followed by others, and by small canines shorter than the molars.

\section{Genus.}

Sorex, Linn. Erxleb. Schreb. Cuv. Lacep. Illig. Musaraneus, Brisson.

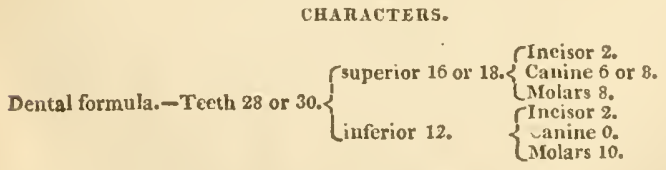

Superior intermediate incisors in form of a dou- 
ble hook, having a short spur situate at their base; inferior incisors elongated, proceeding straight from the alveoles, and are recurved only at their extremity. False canine, particularly the superior, much smaller than the intermediate incisors. Molars with broad crowns, having sharp tubercles, the superior are largest and have the cutting surface oblique; head very long; nose elongated and moveable; ears short and rounded; eyes small but visible.

Tail more or less long, sometimes quadrangular, sometimes partly compressed, at others teretile. Borly covered with fine short hair ; feet terminated by feeble toes, separate, furnished with hooked nails, not proper for digging the earth ; mammæ, both pectoral and ventral, to the number of six or eight; a sebaceous gland on each flank, surrounded by stiff and compact hairs, secreting an oily liquor.

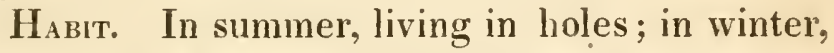
penetrating hay-mows; feeding on worms and insects; of slow progression; during the rutting season they diffuse a strong odour; hence their vulgar name, "pole-cat shrew."

Inhabit temperate climates of both continents,

\section{Species.}

1. Sorex constrictus, Herman, obs. Zool. p. 47. Bodd. Elench. Anim. p. 123. Sp. 4. Geoff. Ann. Mus. d'hist. Nat. t. 17, p. 178 . Sp. 6. pl, 3, fig. 1. 
Sorex cunicularis, Brechstein, Zool. Musaraigne plaron, Vic. d'Azyr, Syst. Anat. des anim. tab. method. (Encycl. pl. supple. 4. fig. 6.)

Char. Essent. Ears very small, hairy, entirely concealed by the skin; colour cinereous-black; tail flattened at its base, and at its point, round in the middle.

Dimensions. Total length, two inches seven lines; length of the tail one inch six lines.

Description. Snout more robust than that of the Sorex araneus; head broader; fascial line more arched; cartilage at the end of the nose, shorter and thicker, which is owing to the coarse hairs which garnish the nostrils; ears entirely concealed by the hairs; two small canines more than in the other species in the upper jaw; tail flat, slender, and as if strangulated at its origin, whilst the remainder, particularly the middle, is thick, as if swolien, and round, except at the extremity, where it is flattened, and where the hairs unite into a point like those of a pencil; fur thick, long, and very soft to the touch, blackish for the greater portion of its length, and red at the extremity; belly grayish-brown; throat cinereous ; feet hairy.

Haвiт. Frequents meadows near the water.

Inhabit Enrope and the United States. 'The specimen in the Philarlelphia Museum, No. 895. was taken near Philadelphia. 


\section{Species.}

2. Sorex araneus, Limn. Gmel. Daubent. Mem. de l'Acad. des Sciences, 1756, p. 212, pl. 5. la Musaraigne, Buffon, hist. Nat. t. 8. pl. 10, fig. 1 . Vicq. d'Azyr, Syst. Anat. des Anim. t. 3. pl. 1. p. 33. Geoff. Ann. Mus. t. 17. p. 203. pl. 2. fig. 2. Schreb. tab. 160. Fetid Shrew, Penn. Quadr. p. 30\%. No. 235.

Char. Essent. Ears large and naked, having within two folds or lobes placed one above the other; colour mouse gray, paler beneath, approaching sometimes yellow or brown; tail square, a little longer than the body.

Dinessions. Total length one inch eleven lines: of the head, eleven lines and a half; of the ears, two lines; of the tail, one inch six lines; of the fore arm, five lines; of the fore-feet, including the nails, three lines and a half; of the leg, five lines and a half; of the hind feet, six lines.

Descruption. Ordinary weight of the animal, three drachms; hair very fine, softer and shorter than that of the monse, which it resembles in colour, but is a little browner on the head and body, and of a deeper gray on the inferior parts; all the hairs being of a cinereous colour for the greater part of their length, and brown at their extremity, mixed with a light teint of yellow above, and upon the sides of the head and borly, and of a gray colour, mixed with a light teint of yellow, beneath the body; ear within large and naked, having two 
folds or lobes one above the other, the inferior of which corresponds to the entrance of the meatus auditorius; tail rather swollen, slightly quadrangular; lips, feet, and tail, flesh-coloured, the last of these parts having sometimes a brownish complexion.

Inhabit Europe and the United States. A specimen in the Philadelphia Museum, No. 896, taken near Philadelphia.

\section{Species.}

3. Sorex parvus, Say. Long's Exped. to the Rocky Mountains, vol. i.p. 163.

Char. Essent. Brownish-cinereous above; beneath cinereous; teeth blackish; tail short, of moderate thicknesss.

Dinensions. From the tip of the nose to the root of the tail, two inches three-eighths; length of the tail three quarters of an inch.

Description. Body above brownish-cinereous; beneath cinereous; head elongatec'; eyes and ears concealed; whiskers long; the iungest nearly attaining the back of the head; nose naked, emarginate; front teeth black; lateral ones piceous; feet whitish, five-toed; nails prominent, acute, white; tail short, subcylindric, of moderate thickness, slightly thicker in the middle, whitish beneath. The specimen is a female.

Inhabits Missouri, near Council Bluffs. 


\section{Species.}

4. Sorex brevicaudus, Say. Long's Exped. vol. i. p. 164.

Char. Essent. Blackish plumbeous above; beneath rather lighter; teeth blackish; tail short, robust.

Dimensions: From the tip of the nose to the root of the tail, three inches five-eighths; length of the tail, one inch.

Description. Above, blackish plumbeous, when viewed from before; silvery plumbeous when viewed from behind; fur dense, rather long; beneath rather paler; head large ; eyes very minute; ears white, entirely concealed beneath the fur; aperture very large, with two distinct semiseptie, which are sparsely hairy at tip; snout short, with a slightly impressed abbreviated line above; nose livid brown, emarginate; mouth margined with whitish and sparse hairs; teeth piceous, black at tip, thirty in all, (as in the S. constrictus:) incisors of the upper jaw compressed laterally and hooked, white and distinct at base, black and approximate at tip, where they are rather pointed; then follow five minute false molars, black at top, crowns with two tubercles, when viewed with the glass, one external the other internal; the most posterior is without black at tip, or tubercles; true molars three in number, proportionally large, furnished each with four sharp tubercles, and as 
many cavities; incisors of the lower jaw, two in number, black at tip on the inferior surface, white above; at base compressed laterally, approximate; at the points slightly divergent, both projecting forwards in the direction of the base of the lower jaw, except at the tips, which are slightly curved upwards; posterior to these are two small false molars; the true molars three in number, similar to those of the upper jaw ; feet white, the second, third, and fourth toes nearly equal, the first and fifth shorter, the former rather shortest; anterior with but very few hairs, nearly naked: nails nearly as long as the toes; tail with rather sparse hairs, slightly thickest in the middle, depressed and nearly as long as the posterior feet; the specimen a male; the skull in the Philadelphia Museum.

Inhabit Missouri. Mr. G. Ord presented me with a scull of a Sorex from the neighbourhood of Philadelphia, which has served the purpose of the above details of the teeth.

\section{Genus.}

Scalops, Cuvier, Geoff. Illig.

Sorex, Linn. Erxleb. Bodd.

Talpa, Penu. Shaw.

('HARACTERS.

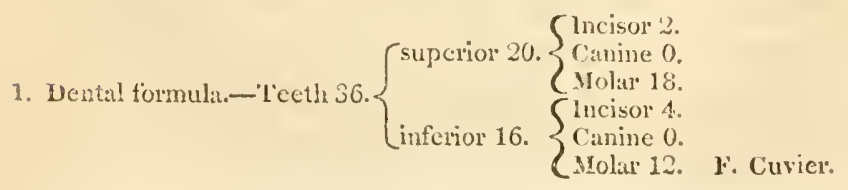


CHARACTERS.

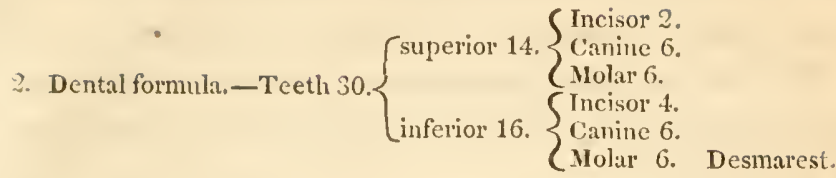

The two intermediate superior incisors very strong and broad, plain and perpendicular to the jaw, and truncated cuneiform; the two external inferior incisors, conical, straight, rather long; and inclosing in their interval two very small, intermediate incisors. A considerable intermediate space in the upper jaw after the two large incisors; a less space in the lower jaw after the lateral incisors.

First and third superior conical teeth, on each. side larger than the second; inferior conical teeth. increasing from the first to the third.

Crowns of the molars furnished with sharp tubercles, the first being antero-posteriorly compressed, is rather thin, and with two points only, the one external, the other internal.

Snout elongated, terminated with a cartilaginous button.

Eyes very small; external ears wanting; feet very short, pentadactyle; the anterior very broad, having the fingers united to the last phalanx; nails long, flattened, linear, and proper for digging; increasing from the thumb to the third finger, the fwo remaining decreasing; the external the small- 
est of all; hind feet very small and very thin; nails small, hooked and arched.

Tail short; body contracted, covered with very short, fine, soft hair, perpendicular to the skin, as in the moles.

\section{Species.}

1. Scalops canadensis. (Encly. pl. 30, fig. 2. Misaraigne brune.)

Sorex aquaticus, Linn. Gmel. Schreb. tab. 158.

Talpa fusca, Penn. Quad. p. 314. n. 245. Shaw, gen. Zool. V. 1. Part. ii. p. 524. Musaraigne taupe, Cuv, tab. Element. des Anim.

Char. Essent. Nose elongated, terminated by a cartilaginous button; the feet and tail of a mole; colour grayish-brown.

Dinersions. Total length six inches three lines; of the head one inch three lines; of the tail nine lines.

Description. Nose very much elongated; nostrils but slightly apparent, opening above near the point; a longitudinal groove beneath, commencing at the upper lip; mouth moderately wide; teeth very strong and white; eyes and meatus auditorius concealed by the hair; hands very strong and broad, fingers united to the commencement of the last phalanx; palms naked, bordered with small stiff hairs; above slightly covered with grrayish down; nails very strong, long, linear and grooved; posterior feet, small, narrow, naked be- 
neath, covered with dowñ above; nails feeble, hooked, and rather sharp : tail short, covered with hair; colour of the animal grayish-fawn; each hair being mouse-gray at its base, and nearly yellow at its extremity.

Habit. Analogous to those of the moles, preferring the borders of rivers and creeks.

Inhabit the United States, from Canada to Virginia. A specimen in the Philadelphia Museum, labelled, "American white mole," No. 872.

\section{Species.}

2. Scalop̋s pennsylvanica, Nob.

I possess the skeleton of a species of this genus, distinct from the $\boldsymbol{S}$. canadensis.

CHARACTERS.

Dental formula.-Teeth $40 .\left\{\begin{array}{l}\text { superior } 24 \\ \text { inferior } 16 .\left\{\begin{array}{l}\text { Incisor } 2 . \\ \text { Canine } 12 . \\ \text { Molar } 6 . \text { false molar } 4 . \\ \text { Incisor } 4 . \\ \text { Canine } 6 . \\ \text { Molar } 6 .\end{array}\right.\end{array}\right.$

Molar teeth nearly approximate, those of the upper jaw having the crowns slightly indented with a transverse furrow, which is continued along the inner side; the crowns of the lower molars deeply marked by a transverse groove, which is continued on the outer side of the teeth.

Form of the incisors similar to those of the preceding species.

Dinensions. Length of the body with the head 
inclusive, four inches six-tenths ; leugth of the tail one inch three-tenths; length of the head one inch four-tenths; extremities like those of the preceding species.

Note. This species corresponds in the number and arrangement of its teeth, with the genus Scalops of F. Cuvier, but the structure of the molars are different from this genus, as described both by Desmarest and Cuvier.

\section{Genus.}

Condylura, Illiger, F. Cuvier, Desm.

Sorex, Linn. Gmel. Erxleb. Bodd.

Scalops, Geoff.

Talpa, G. Cuv. Penn. Gmel.

CHARACTERS.

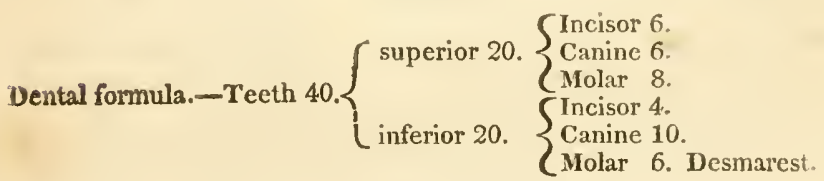

Six anomalous superior incisors, implanted in the intermaxillary bone; the two intermediate very broad, contiguous, garnishing the whole border of the jaw, scooped, with their cutting edges rather oblique, having the angle by which they touch more projecting than the external angle; the succeeding incisor on each side, touching the intermediate, resembling a very long pointed canine, somewhat triangular at base, where there 
exist two very small tubercles, one before, the other behind; the external or lateral incisor the smallest of all, simply conic, slightly compressed, and recurved at the point, placed at some distance from the incisor in form of a canine.

Four inferior incisors flattened, projecting and scooped; the lateral lay in part horizontally on the intermediate, slightly elevated at the extreme border.

Three conical teeth, (false molars, or false canines) in the upper jaw on each side, separated from each other, rather wide, and furnished each with a small pointed lobe at base, and one also posteriorly; five teeth in the lower jaw on each side, similar to these, separated from each other; the first being largest, in which only it resembles a canine, having three lobes, the principal of which is intermediate, the first nearly effaced, and the posterior slightly projecting; the second nearly similar, but shorter and more compressed, with the posterior lobe more apparent than in the pre. ceding; the third has four lobes, a small one anteriorly; a second, the largest of all, and the most apparent, and two small ones posteriorly; the fourth nearly like the third, with this difference, that the first posterior lobe is more internal, which makes the tooth thicker; the fifth differs from the first only in being broader, nearly equal to the first molar; four superior true molars on each side, composed each of two folds of enamel, form- 
ing two sharp tubercles on the internal side, and grooved obliquely into furrows on the external side; a spur on the internal base of these teeth; the most anterior being the smallest, increasing to the last, which is smaller than the third; inferior true molars three on each side, presenting like the superior, two folds of enamel; the disposition of these folds being inverse, the points in place of being internal are external.

Snout very much elongated, sometimes furnished with a membranous crest, disposed in form of a star around the opening of the nostrils.

No external ears; eyes extremely small ; anterior feet short, broad, five toes furnished with strong nails proper for digging; posterior feet slender, five-toed.

Tail moderately long; body clumsy, covered with very fine soft and short hair, perpendicular to the skin.

Habit. Analogous to the mole.

Inhabit North America.

\section{Species.}

1. Condylura cristata, Desm. Mlamma. (Encycl. pl. suppl. 4. fig. 7.) Taupe du Canada. Delafaille, Essay sur l'hist. Nat. de la taupe, figd. $176 \%$. Buffon, hist. Nat. t. 6. pl. 37.

Sorex cristatus, Linn. Erxleb. Gmel. Bodd.

Radialed Mole, Penn. Syn. Quad. p. 313, 1. 243, 1ab. 28, fig. 1. Desm. Note sur le genre 
Condylure, Journal de Phys. 1819. pl. 2. ("Star nosed mole," Philadelphia Museum, No. 876.)

Char. Essent. Nostrils surrounded by a circular membrane, in form of a star; tail, less than half the length of the body.

Dinensions. 'Total length, four inches ; circumference of the fringed disk of the snout, five lines; total length of the hand, six lines; of the foot, ten lines; of the largest nail of the fore feet, two lines and a half; length of the tail, one inch eight lines: distance between the eyes, three lines.

Description. Snout very much elongated, wrinkled, provided with a small bone, and furnished at the point with a naked disk, which encloses in its centre the openings of the nostrils, the borders of which are furnished with cartilaginous points, of a rose colour, moveable, and with a granulated surface, twenty in number; the two superior intermediate ones, and the four inferior intermediate, are united at base, and placed on a plane more advanced than the others; neck not distinct; anterior feet very short, with the hands very broad, naked, scaly; lower cutting surface less marked than in the mole; five short toes, united to the second phalanx, and furnished with strong nails, straight, rather broad, linear, of different relative lengths; hind feet proportionally longer than those of the mole properly so called, being one-third longer than the anterior feet, slen- 
der, feeble, naked and scaly; all the phalanges being free; nails less long than those of the hand. less broad, but more curved; tail rather slender, with its vertebræ slightly projecting; the skin which covers it divided into transverse folds, scaly; between which project hairs more rare and stiff than on other parts of the body.

Fur short, very soft, rather coarser and more sparse than that of the common mole of Europe, but of the same blackish-gray velvet.

Whiskers composed of stiff hairs, rather long, elevated, nearly parallel and directed forwards; the external borders of the hands furnished with a series of stiff hairs, slightly recurved towards the palm, which is absolutely naked. Palate wrinkled transversely; lower jaw very thin and slender; sixteen vertebra to the tail.

Haвiт. Not sufficiently observed; possesses the faculty of moving the membrane on the end of the nose.

Inhabit Canada and the United States; very common in Pennsylvania and New Jer'sey.

\section{Species.}

2. Condylura longicaudata, Desm. Mam. longtailed mole, Penn. Syn. Quad. p. 314. No. 244. tab. 16, fig. 2. Talpa longicaudata, Erxleb. Syst. Anim. t. 1. p. 118. Gmel. Syst. Nat. Bodd. p. 126. sp. 2. (Encycl. pl. 28, fig. 5.) 
Char. Essent. No nasal crest; tail as long as one half the body.

Dimensions. Length of the head and body from four to six inches.

Description. Anterior feet broad, and constructed like those of the European mole; hind feet scaly and beset with sparse short hairs; toes long and thin; hair of the body soft, ferruginous brown; tail covered with short hair.

Inhabits North America.

\section{Species.}

\section{Condylura macroura, Nob.}

Char. Essent. Nose surrounded with a circular fringed membrane, asteriform; tail nearly the length of the body, round and appearing strangulated at base, becoming suddenly enlarged, slightly compressed and tapering.

Dimensions. Total length, five inches four lines; length of the hands, seven lines; length of the hind feet, one inch; longest nail of the hand, twoeighths. (Extremity of the tail lost.)

CHaracters.

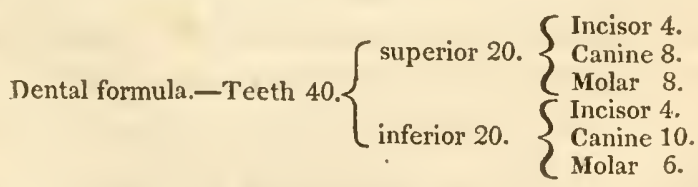

Note. There is no rule by which to determine in this genus, the distinction of the various kinds 
of teeth. Thus Desmarest gives them incis. $\frac{6}{4}$, and allows six false molars above, and eight mo lars proper; whilst F. Cuvier gives as characteristic of his genus Condylura, two incis. two canine, ten false molars, and six true molars, to the upper jaw, but the total number of teeth is similar in all; the differences exist only in the names by which the teeth have been designated.*

Description. Snout very much elongated, a longitudinal wrinkle on the upper surface, and on each side; cartilaginous points on the nose twenty in number; hands short and broad, naked, except at the upper border, which is lined with hair; nails strong, short, and flat, with cutting borders, not curved or arched at the extremity, nor pointed as in the $\boldsymbol{C}$. cristata; tail more than one half the length of the body, thick, compressed, and tapering, furnished with coarse scales, clothed throughout with sparse, short, thick hairs; colour of the back, blackish-gray; the snout, fawn colour, darker on the sides. A specimen in the Philadelphia Museum, No. 866.

* According to the olservations of Dr. Dekay, the total number of teeth in this genus is 44 ; but 2 of the upper incisors are mere rudiments. His dental formula stands thus:

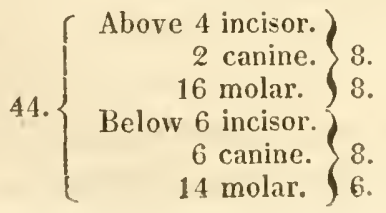


Inhabit the United States, abound in New Jer: ser.

\section{Genus.}

Talpa, Linn. Briss. Erxleb. Bodd. Cuv. Lacep. Geoff. Illig.

\section{CHARACTEIS.}

Dental formula.-Teeth 44. $\left\{\begin{aligned} \text { superior } 22 . & \begin{array}{l}\text { Incisor } 6 . \\ \text { Canine } 2 . \\ \text { Molar } 14 .\end{array} \\ \text { inferior 22. } & \left\{\begin{array}{l}\text { Incisor } 8 . \\ \text { Canine } 0 . \\ \text { Molar } 14 .\end{array}\right.\end{aligned}\right.$

Superior incisors small, vertical, nearly equal in height, the intermediate being broader than the lateral; inferior incisors small, disposed in an arch, slightly projecting.

Canines surpassing the incisors, triangular, compressed, the superior being larger than the inferior, and having two roots.

The three anterior molars of the upper jaw very small, placed in the most narrow portion of the mouth, having nearly the same form as the canines, only smaller; the fourth triquetrous at its base; crown consisting of but one point; the crown of the fifth has a cutting border with two points, the posterior of which is largest, and furnished with a small spur anteriorly, presenting a small point; the sixth is largest of all, in other resnects similar to the fifth; the seventh 
triangular, with the summit exterior and directed transversely.

The two first inferior molars like canine, but smaller; the third cutting, pointed, triangular, with a small spur posteriorly; the three last larger, particularly the penultimate; all composed of an external cutting border, divided into three sharp tubercles, and a double spur, for the two first; one for the posterior.

Head elongated; eyes very small; no external ears.

Extremities short, five-toed, anterior stronger than the posterior, terminated by very broad hands, having the hand always turned outward and backward; the internal border cutting, and the fingers united to the base of the nails, which are slightly arched, Jong, strong, and cutting; hind feet more slender; toes nore feeble, more distinct or separate, and furnished with moderate sized nails.

Tail short, sparsely hairy.

Six abdominal mammæ.

Body covered with short, fine, very soft hair, perpendicular to the body.

(For the anatomy, see the Dict. d'hist. Nat. art. Taupe.)

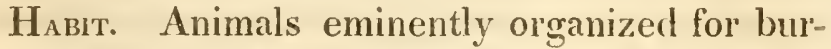
rowing; feeding on insects, larve, earth worms, tender roots, \&c. having the organs of hearing and of touch very perfect. 
Species.

Talpa Europea, Linn. Erxleb. Bodd.

T'alpa vulgaris, Briss. regn. Anim. p. 220, n. 1. la taupe, Buff. hist. Nat. tom. 8. p. 81. pl. 12.

Mole, Pennant, Brit. Zool. p. 52.

Talpa americana, black mole, Bartram's manuscript notes.*

Char. Essent. Fur soft, black, and shining; tail short.

Dinensions. Total length from the base of the tail to the extremity of the snout, five inches; length of the head, one inch six lines; of the tail, one inch two lines; of the fore-arm, eight lines; of the hand, nine lines and a half; of the leg, nine lines; of the longest nail of the fore foot, three lines and a half; of the longest nail of the hind foot, one line and a half.

Description. Body thick, oblong, nearly cylindrical, training on the earth; head pointed, terminated in a snout; eyes exceedingly small, black, situated in the middle of a space of two lines in diameter, destitute of hairs; ears without a concha, only observable externally by the meatus audito. rius, the borders of which are slightly projecting

* That venerable naturalist, the late Mr. WiLLiam Bartram, was accustomed to keep a diary, or " A calendar of natural history," in which he carefully noted his daily observations, almost up to the hour of his death; these were never intended for publication, but since this work went to press, his relative, Maj. Robert Carr, (the present proprietor of the Gardens,) has politely fa. voured me with a perusal of them. 
beneath the skin in the inferior portion of the circle which they form; anterior feet very robust, thick; fingers short, armed with nails equally long; wrists concealed in the hair; tail scaly like that of the rat, but furnished with longer hair; anus projecting and very distant from the origin of the tail; fur soft, shining, and of a cinereous colour, taking different teints, as it is viewed in various directions; a light teint of fawn on the lower jaw and middle of the belly.

The following are varieties; spotted, white. yellow, and cinereous.

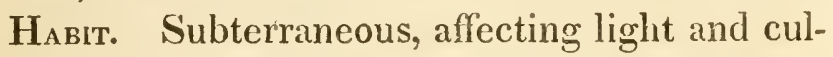
tivated soils; changing locality according to atmospherical variations; seeking elevated regions during the rainy seasons; excavating long galleries which all communicate with each other, parallel to the surface of the soil, and at moderate depths ; elevating the earth into what are denominated mole-hills; excavating with their hands, and raising the earth with their head; feeding on worms, insects, roots, bulbs of colchicum, \&c. ; entering in rut early in the spring, and bringing forth twice annually, four or five at a birth, between the months of March and August; raising their young with the greatest tenderness; forming their nests of leaves, in a spacious chamber, the vault of which is supported by pillars, and which is situated in a manner to be sheltered from inundations. 


\section{Family CARNIVORA.}

Char. Six incisors in each jaw; molars most generally cutting, sometimes tuberculous; the crowns never furnished with sharp tubercles; cauines very strong.

1st Tribe, Plantigrada.

Char. Entire soles of the hind feet resting on the soil; five toes to each foot.

\section{Genus.}

Ursus, Linn. Schreb. Lacep. Cuv. Geoff. Illig. Prochilus, Illig.

ChARACTERS.

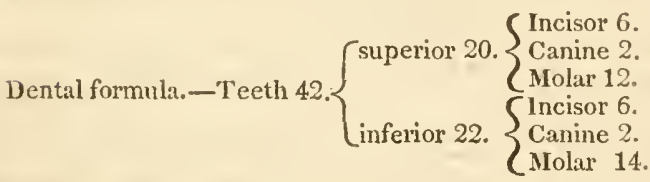

Incisors regular; the two exterior stronger and more pointed than the four intermediate; these two teeth in the lower jaw being broad, pointed, having a very distinct lateral lobe at their external base; canines strong and conical; number of molars varying according to age; three very broad, with square crowns, entirely tuberculous; the false molars small, obtuse, and separate; body clumsr, covered with thick fur. 
Head thick, with the snout more or less elongated and moveable; tongue smooth ; feet pentadactyle, all armed with very strong nails, more or less curved; tail short; six mammæ, two pectoral, and four ventral; no cæcum.

Habit. Preferring cold or elevated countries for the most part; of slow progression; feeding on wild fruits, roots, herbs, honey, as well as on animal matter ; others eating only corrupted flesh; hibernating in winter, during which they" bring forth their young from one to five at a birth.

According to the testimony of hunters, they come forth in spring nearly as fat as when they retired, and soon become thin by exercise; which fact was remarked by Aristolle.

Inhabit Europe, Asia, and America.

\section{Species.}

1. Ursus arctos, Linn. Erxleb. Bodd. Ours, Buff. t. 8. pl. 31. Perrault, Anim. p. 258. No. 1. G. Cuv. Mènag. des Mus. fig. E. Cuv. Mamm. lithogr. Brown bear.

Char. Essent. Fascial line convex above the eyes; snout abruptly diminishing; sole of the fcet of moderate length; colour brown.

Dinensions. Total length, three fect four inches. six lines; length of the head, eleven inches three lines; height before, two feet one inch; length of the fore feet, nails inclusire, seren inches two 
lines; of the hind feet, eight inches four lines. (They vary in size from three to five feet.)

Description. (Alpine brown bear, adult.) Body entirely covered with very thick hair, long and rather soft, generally of a chesnut brown, deep on the shoulders, the back, thighs, and legs, and glazed with yellow on the sides of the head to the ears, and on the flanks; hair of the feet short and nearly black, as well as that on the snout, which is nevertheless in some degree browner; soles of the hind feet proportionally shorter than those of the white bear, and longer than those of the black bear, entirely naked, and marked by four folds which correspond to the divisions of the fingers, which are separated from the sole, properly speaking, by hairs, each finger being furnished with an elliptical tubercle; anterior half only of the fore feet naked, and provided posteriorly with a naked tubercle, surrounded with hair; naked part of the hand marked by three folds, two of which correspond to two internal fingers, and the third circumscribes the part which relates to the two external; fingers furmished with elliptical tubercles like those of the toes, the middle one being in all cases the longest, and the others diminishing gradually; nails strong and cutting ; eye small ; iris brown; nostrils opening before a glandular muzzle, and passing to the sirles, curved upwards in form of a slit; ears with an extermal concha. very simple and rounded; 
tongue smooth, narrow and long; lips very extensible. (F. Cuv.)

Haвiт. Frequent the most solitary places, the deepest forests, the highest and most inaccessible mountains ; resorting to caverns or hollow trees; hibernating. They copulate in October; the female brings forth in spring, after a hundred and two days of gestation, from one to five young at a birth, according to her age. The brown bear is less ferocious than the polar bear; feeds principally on vegetable substances, and attacks animals only when hard pressed by hunger, when they unite in troops more or less numerous. In order to combat, they raise themselves on their hind legs, and endeavour to suffocate their adversary with their fore paws.

Inhabits the mountains of Europe, Asia, Africa, and western parts of North America. (The identity of the American and European species, not certainly ascertained.)

\section{Species.}

2. Ursus cinereus, Desm.

Ursus ferox, Lewis and Clark's voyage to the Missouri.

Gray or grizzly bear, Warden. Descrip. des Etats unis, v. 5, p. 609.

Ursus horribilis, Ord. Guthrie's Geog, v, 2, p. 299.

Char. Essent. Hair long, abundant, particular- 
ly about the head and neck; colour grayish, sometimes bordering on brown or white; anterior claws elongated; facial line rectilinear, or slightly arched.

Dimensions. Total length, eight feet seven inches six lines; greatest circumference, five feet ten inches; circumference of the neck, three feet eleven inches; of the middle of the leg, one foot eleven inches; length of the claws, four inches five lines.

Description. This animal is best described by Mr. Say, (Long's Exp. to the Rocky Mountains, p. 52,) under the name of $U$. horribilis, but having been taken chiefly from the prepared specimens of a male and female in the Philadelphia Museum, must necessarily be imperfect in some respects, inasmuch as these individuals were captured very young, and brought up in a confined cage, and when killed had not attained a state of maturity and full growth. These circumstances would materially change the quality and colour of the hair, nails, and other superficial characters. Nevertheless, to Mr. Say is due the credit of having first noticed those specific characters which establish this as a distinct species from any previously described. Desmarest in his Mammalogie, so late as 1820 , remarks, "the only characters which induce us to place this species here, are taken from its enormous size; for all the information we possess besides, concerning this individual. 
is not sufficiently detailed to enable us to distinguish it from the preceding."

From the work first quoted we shall notice those characters which are most permanent: "ears short, rounded; front arcuated; the line of the profile continued upon the snout, without any indentation between the eyes; eyes very small; end of the nose black; sinus very distinct and profound; tail very short, concealed by the hair; anterior feet, claws elongated, slender; fingers with five suboval naked tubercles, separated from the palm, from each other, and from the base of the claws, by dense hair; palm, anterior half, naked, transversely oval ; base of the palm with a rounded naked tubercle, surrounded by the hair; posterior feet with the sole naked; the nails moderate, more arcuated and shorter than the anterior ones; the nails do not in the least diminish in width at the tip, but become smaller towards that part only by diminishing from beneath; lower surface of the claws split so as to form a longitudinal groove.

"Length of the prepared specimen, five feet two inches; of the tail, exclusive of the hair, one inch and three quarters."

For interesting particulars concerning the habits of this animal, I must refor to Lewis and Clark's Voyage up the Missoni. 


\section{Species.}

3. Ursus americanus, Pallas, Cuv.

Black bear, (Philad. Museum.)

Ursus gulaire, Geoff.

Char. Essent. Nose nearly on the same line with the forehead, but more arched than in the Cinereus; palms of the hands and soles of the feet very short; hair shining black, not curled.

Dimensions. Total length five feet eight inches; length of the tail, one inch six lines.

Description. Facial line less arched than in the brown bear; ears larger and more separated; feet shorter; sides of the nose marked more or less with yellow.

In the state of New York they distinguish two varieties of this species, viz. the long legged and short legged bear.

Inhabits Canada and the United States, from the district of Maine to the Pacific ocean, and as far south as Carolina. Lewis and Clark met them on the Rocky Mountains, and on the borders of Columbia river.

\section{Species.}

4. Ursus maritimus, Polar bear, Linn. Sabine, append. Ursus albus, Briss. regn. anim.

Ours blanc, Buff. suppl. v. 3, pl. 34.

Polar bear, Penn.

Char. Essent. Head elongated; cranium flat- 
tened; neck long; sole of the foot very large; hair long, soft and white.

Dimensions. Total length, five feet seven inches one line; of the head, one foot five inches six lines; of the palm of the hand, ten inches two lines; of the sole of the foot, eleven inches nine lines; of the tail, two inches nine lines; height before, three feet four inches.

Description. Body and neck much longer in proportion, head more narrow and more flat than in the brown bear; forehead nearly in a straight line with the nose; snout thicker than in the European species; ears shorter, more round; hind feet about one-sixth of the total length, resting on the entire sole and heel; hair soft, fine, and woolly, very long on the belly and legs, rather short on the head and superior parts of the body; white on all parts; end of the nose, nails, and borders of the eyelids, of a deep black; lips bordering on the violet; interior of the mouth of a pale violet; a small supernumerary conical tooth, situated behind the canine of both jaws, and separated from the first molar by a vacant space.

НАвгт. Very voracious and savage, carnivorous, swimming with the greatest facility, and reposing on floating ice. Female brings forth in the month of March, after six or seven months gestation; reposing the young in deep pits made in the snow, where they pass the winter, isolated, and in a lethargic state. 
Inhabits the rivers of the frozen ocean, Spitzburg and the most northern coasts of America; Mellvil island, west coast of Davis's strait, according to Sabine.

\section{Genus.}

Procyon, Storr, Cuv.

Ursus, Linn. Erxleb. Bodd. Gmel.

Coati, Klein.

Lotor, Tiedmaun.

CHARACTERS.

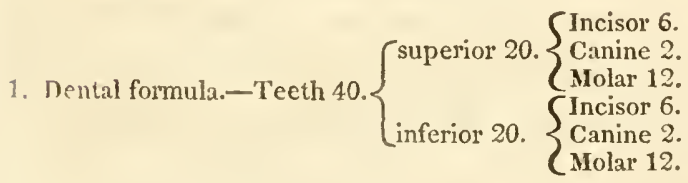

fifferior incisors regularly arranged.

('anine large and compressed; the three first nolars simple, triangular, pointed, distant from each other; the three last tuberculous; the fourth presenting three points on its external border; the fifth almost entirely tuberculous, and the strongest of all; the sixth entirely tuberculous.

Body low set.

Snout pointed.

External ears smail, oval.

'Tongue soft.

Tail long and pointed, not prehensile.

Feet pentadactyle, armed with rather sharp 
nails; during progression the heel does not rest entirely upon the soil.

Six ventral mammæ.

Haвiт. Feeding like the bear on animal and vegetable substances; more active than these animals; climbing trees with facility.

Inhabit both North and South America.

Species.

1. Ursus lotor, Linn. Erxleb. Bodd.

Le Raton, Buffon, hist. nat. tom. 8. pl. 43.

Procyon lotor, Cuvier, Regne anim. p. 143.

Vulpes americana, Charleton. Coati Brasiliensium, Klein. Agouarapopé, d'Azara, Essai sur l'hist. nat. des quadr. du Paraguay. Mapach, of the Mexicans.

Raccoon of the Americans.

Char. Essent. Colour grayish-brown; snout white, with a brown line passing through the eyes; tail ringed with brown and white.

Dimensions. Length of the body, one foot nine inches three lines; of the head, five inches nine lines; of the tail, eight inches six lines; greatest height one foot.

Description. (Male,) pupil of the eye round; nose prolonged beyond the jaws, but less than the nose of the Coati, terminating in a glandular muzzle, at the end of which open the nostrils, which are prolonged on the sides and curve upwards; lips extensible; ears elliptical, very simple; skin 
of the soles of the feet very delicate; penis almost entirely bony, directed forwards in a sheath; glans rounded, divided by a groove, curving downwards; testicles in part concealed beneath the skin; fore feet five-toed, furnished beneath with thick tubercles, the thumb being shortest, next the little finger, then the finger next the thumb, the two remaining longest and equal; nails proper for digging, long and strong; five elastic tubercles on the palm; one near the wrist, another at the base of the little finger, a third at the origin of the thumb, a fourth opposite the second finger, and $a$ fifth at the base of the two large fingers.

The hind feet similarly constructed.

General colour of the body blackish-gray; paler beneath the belly and on the legs; hairs ringed with black and dirty white; tail tufted, having five or six black rings upon a yellowish-white base; ears whitish; snout whitish before, with a black spot embracing the eye, and descending obliquely to the inferior jaw; the hairs of those parts comprised between this spot and the ear; those of the cheeks and eyebrows, nearly white, and rather long, directed downwards; snout in general covered with short hairs, black above; whiskers long and strong on the upper lip; feet covered with short hairs; the woolly hair of the body being deep gray and very thick. (F. Cuvier.)

Female rather smaller than the male. 
Variety, A. Fawn-coloured raccoon.

B. Brown-throat raccoon.

C. White raccoon.

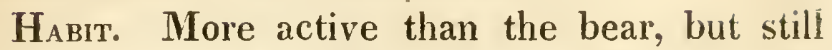
having the awkward gait of the plantigrade animals; supporting themselves with ease on their hind feet, and holding their food with the fore feet; constantly plunging the food in water, and rolling it between the hands before eating; nocturnal ; feeding on roots, fruits, insects, birds, \&c.

Inhabit North America, Mexico, West Indies.

In the United States they are found as far north as Lake Ontario.

\section{Genus.}

Taxus, Linn. Geoff.

Meles, Briss. Storr. Bodd. Cuv. Illig.

Ursus, Linn. Erxleb.

CHaAaCTERS.

$$
\text { Dental formula.-Teeth 36. } \begin{cases}\text { superior 16. } & \left\{\begin{array}{l}
\text { Incisor 6. } \\
\text { Canine 2. } \\
\text { Iolar 8. } \\
\text { inferior 20. }
\end{array}\right. \\
\left\{\begin{array}{l}
\text { Incisor 6. } \\
\text { Canine 2. } \\
\text { Molar 12. }
\end{array}\right.\end{cases}
$$

Second incisor on each side of the lower jaw, placed a little farther back than the others; canines strong; superior molars form an uninterrupted series: the first linear and small, the second and third flattened laterally, and having a single sharp point; the penultimate triangular; the last very large and broad. 
Of the six inferior molars, the first is rudimental, linear, scarcely apparent; the three following flattened laterally; the fifth being largest and having three sharp points.

Body thick set, low upon the legs; snout somewhat elongated; ears short and round; eyes very small; tongue smooth ; feet five-toed, armed with strong nails; tail very short; a pouch between the anus and tail, having a transverse orifice, discharging a fetid matter; hair coarse and long.

$\mathrm{H}_{\text {Aвіт. Analogous to bears. Inhabit Europe, }}$ Asia, and North America.

\section{Species.}

1. Meles labradoria, American badger, Sabine's appendix to Capt. Parry's Voyage to the Polar sea, p. 649, who proved it a distinct species from the "Meles vulgaris," of Desmarest, with which it had been confounded by all previous authors.

Desmarest remarks, (vide Mammalogie, p. 173) "Le carcajou figurè par Buffon dans ses supplèments. (Encycl. pl. 38, fig. 2.) Ursus labradoricus, Gmel. est un vrai blaireau du pays des Eskimaux, il en est venu en France qui avoient ètè pris en Canada."

Char. Essent. Colour of the animal above, ferruginous brown; a broad whitish longitudinal line divides the liead above into two equal parts, and is continued along the back; lower surface of the fore feet, black. 
Dimensions. Total length of the male, two feet two inches, not including the tail ; female considerably smaller.

Description. The following details are taken from well prepared specimens, a male and female in the Philadelphia Museum, No. 786 and 787.

The back of the animal of a ferruginous brown colour; hairs at base whitish, then brown, then tipt with gray ; sides of the snout of a dark brown; those hairs are blackest which cover the upper surface of the anterior feet; snout contracted, broad at base, pointed at the extremity; nostrils open downwards, curving upwards posteriorly, to form a lateral and vertical slit; end of the nose continued beyond the upper lip; external ear small; the borders of the pinnæ, ovoid; a broad row of reversed hairs anterior to the concha; nails on the fore claws, strong, equally as long as the palm, slightly curved and very sharp; nails of the posterior feet slender, short, and sharp; tail about the length of the hind leg, covered with long hairs; hair of the body long, rather coarse.

Навіт. Frequents the most solitary places; lives in holes; nocturnal; omnivorous. When attacked, it defends itself with courage; biting with tenacity, for which it is well calculated by the manner of the articulation of the lower jaw; the coronoid processes being completely locked within the zygomatic arch.

Inhabit North America. 


\section{Genus.}

Gulo, Retzius, Storr, Cuv. Illig.

Mustela, Limn.

Ursus, Linn. Gmel.

Meles, Bodd. Desm.

Mellivora, Storr.

CHARACTERs.

Dental formula. -34 or 38 teeth. $\left\{\begin{array}{l}\text { superior } 16 \text { or } 18 .\left\{\begin{array}{l}\text { Incisor } 6 . \\ \text { Canine } 2 . \\ \text { Molar } 8 \text { or } 10 . \\ \text { inferior } 18 \text { or } 20 .\end{array}\right. \\ \begin{array}{l}\text { Incisor } 6 . \\ \text { Canine } 2 . \\ \text { Molar } 10 \text { or } 12 .\end{array}\end{array}\right.$

Second incisors of the lower jaw receding; canines strong; the first two or three superior molars compressed, cutting, unicuspid; the fourth large and bicuspid; fifth small and tuberculous. The first four molars of the lower jaw unicuspid; fifth bicuspid; the last tuberculous ; all approximate.

Body low set; sometimes long; head slightly elongated; ears very short and round; tongue sometimes smooth, at other times rough : five distinct toes on each foot, armed with hooked nails; nearly the entire sole of the hind feet resting on the ground; no pouch near the anus; two slight cuticular folds replace them.

Навіт. Carnivorous; analogous to that of the martins.

Inhabit America, north of Asia, and Africa. 


\section{Species.}

1. Gulo arcticus, Sab. Desm. Mammalogie, p. 174. Encycl. pl. 38, fig. 1. Northern glutton.

Ursus gulo, Pall. Linn. Erxleb. Schreb.

Meles gulo, Bodd.

Ursus luscus, Linn. Gmel.

Wolverene, Pemn.

Char. Essent. Body squat; greneral colour of a fine deep chesnut, with a disk nearly black upon the back.

Dimensions. Total length two feet two inches; length of the fore leg; eleven inches; of the hind leg, twelve inches; length of the tail, comprising the hair at its extremity, which is four inches, eight inches.

Description. Snout black as far as the eyebrows; eyes small; between the eye-brows and ears, of a brownish-white colour; lower jaw and interior of the fore feet, spotted with white; a tubercle under each toe; four others on the palm of the hand.

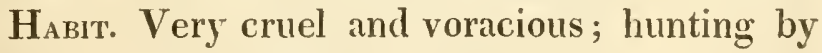
night; not hibernating.

Inhabits countries bordering on the north sea, both of Europe and of Asia. In America they inhabit Canada, and the uncultivated parts of the United States, where its depredatious are often experienced by the Indians. 


\section{Genus.}

Mustela, Linn. Briss. Erxleb. Schreb. Bodd. Cuv. Geoff. Illig.

CHaracters.

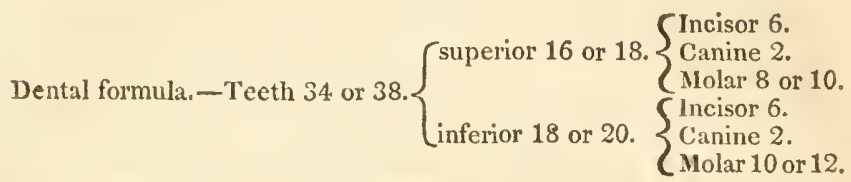

Second inferior incisors of each side in a slight degree receding; canines strong; molars cutting; the anterior false molars conical and compressed; sometimes two above and three below, at other times three above and four below; true molars trilobate; the last molar with a blunt crown; body long and thin; arched when the animal is in a state of repose; head small, oval, flat above; jaws short; ears short and round; tongue smooth; feet five toed, armed with sharp crooked claws; small glands near the anus, which secrete copiously an extremely fetid fluid, when the animal is irritated; hair fine and soft ; no cæcum ; furnished with ventral mammæ.

Haвıт. Carnivorous, voracious; killing small quadrupeds and birds, \&c.

Inhabit temperate and northern climates in both countries.

Species.

1. Mustela vulgaris, Linn. Erxleb. Bodd. Belette, Buff, the Weasel, Penn. Brit. Zool. p. 39. 
Char. Essent. Universal colour of the animal a ferruginous brown, rather darkest on the posterior half of the tail.

Description. Head proportionably broader, thicker, and shorter than the head of the ermines; opening of the nostrils curved backwards inferiorly, forming a lateral slit; ears short, broad, rounded; hands and feet covered with hair on their upper surface; hair at the extremity of the fingers projecting beyond the nails, which are short, strong and hooked.

HABIT. Like its congeners, carnivorous, voracious, very destructive to eggs and poultry; exceedingly alert and rapid in its motions, producing two or three times a year three or five at a birth.

Inhabits North America, abounds in the Atlantic states-and northern parts of the old continent.

\section{Species.}

2. Mustela erminea, Linn. Gmel. Bodd. Encyc. pl. 83. fig. 2. (Philad. Mus. ermine, No. 750) Sab. append.

Char. Essent. General colour during the summer, pale chesnut brown above, and white beneath; general colour during winter, white; tail always black or reddish-brown at the extremity.

Dimensions. 'Total length, about twelve inches; length of the tail, nearly five inches.

Description. (From a prepared specimen in a winter dress,) general colour white, slightly tinged 
with yellow along the sides; outer part of the. thighs and arms, extremity of the tail penciled with very long hair, about one inch of which is reddish-brown; head, neck and body, elongated; ears broader, but not so long or distinctly rounded as in the preceding species; anterior margin furnished with long hairs which nearly cover the concha; nails entirely hid, from above, by long thick hair, which covers them on the upper surface.

Н

Inhabit the northern and middle states.

Species.

3. Mustela lutreocephala, Nob. Under this name I wish to make known an animal hitherto confounded with the $M$ M. lutreola, (Pailas, spicil. Zoolog. 14. pl. 31. Lutra minor, Erxleb. mem. de. Stock. 1739, tab. 11.) or with the M. vison. Linn. Gmel.

It resembles most nearly the "lutreola," yet is characteristically distinguished by its form, colour, size and markings; it was indeed noticed as specifically different from the "lutreola" by Warden, (descrip. des Etats unis, vol. v. p. 613) who, speaking of the American Mink, says "We do not think this Martin (Mink) similar to the $\boldsymbol{M}$. lutreola, (Pall.) which is a Swedish animal; although many naturalists have confounded the two, we have reason to believe them different, 
though both have a common name, and there exists much resemblance in their natural habits."

The specimen here described, was obtained and prepared by Mr. C. W. Peale many years ago, in Maryland.

Char. Essent. General colour brownish white, lightest beneath; tail ferruginous brown; length of the animal nearly double that of the "lutreola."

Dimensions. Total length, one foot eight inches; length of the tail, about nine inches.

Description. In form, the head and ears resemble those of the otter; the hair, the tail, and general proportion of the body, are more analogous to those of the weasel; body long; feet short; toes united to the middle, of equal length, slightly palmated, and furnished with very small sharp nails, nearly covered with hair.

HabIT. According to Warden, this animal resides in the ground near to streams, in which it pursues its prey, consisting of fish, aquatic birds, rats, mice, insects, moles, and eggs of tortoises; during the night, entering the farm yards and destroying poultry; when famished it demonstrates astonishing boldness.

Inhabits the United States.

Noте.-Mustela lutreola, Sab. append. to Franklin's, Exped. p. 649, was described by Foster, (Philos. 'Trans.) as the same with the European. .M. Zibellina, (Sable weasel) Linn. Erxleb. 
Borld. Inhabit Kantchatka, and agreeably to some authors, the United States; I have no knowledge of their existence in this country.

\section{Species.}

4. Mustela vison, Linn. Gmel. Desm. Mamm. 1. 183. Le vison, Buffon, hist. nat. tom. 13. pl. 43. Minx of Americans.

Char. Essent. General colour brown, more or less deep; point of the inferior jaw white; tail of a blackish brown; feet demipalmated.

Dimexsions. Total length, about fifteen inches, not including the tail.

Description. Longु hairs of the body brown, more or less tinged with yellow; next the skin, a thick ash coloured down, of a pale yellow at tip : tail moderately long, blackish ; feet hairy.

HАвiт. Living in holes, on the borders of water; female producing from three to six at a birth; manners similar to the preceding species.

Inhabits Canada, and the northern and middle states.

\section{Species.}

5. Mustela canadensis, Linn. Erxleb. Schreb. Pekan weisel, Penn. Quad. p. 331. Desm. Mamm. p. 186. (Encyc. pl. 80. fig. 4.)

Le pekan, Buffon, hist. nat. 5. 13. pl. 42. 'The fisher, Philad. Mus. No. 736, from the western states. Fisher weasel or martin of others. 
Char. Essent. Head, neck, shoulders, and top of the back, mixed with gray and brown; nose, rump, tail, and extremities of a blackish brown; often a white spot beneath the throat.

Dinensions. 'Total length, sixteen inches; length of the tail, ten inches.

Description. Body covered with two sorts of hair, for the most part with a down of an ash colour, the ends of which are gray, with some shades of yellow; hairs strong, presenting the same colour with the down, except at the tips, which are gray and black; some hairs of a chesnut colour tipt with black; the general colour resulting from these mixtures, is a gray and yellow on the head, neck, back, shoulders and upper part of the fore leg; flanks more gray than the back; rump blackish; lower part of the fore legs, whole of the hind legs, the fore feet and tail black, with some shades of brown; in some individuals, white between the fore and hind legs, on the breast, and belly.

Habrt. Similar to the preceding.

Inhabits Canada and the northern states.

Fisher weasel, Penn. Quad. p. 328, No. 202.

Mustela pennanti, Erxleb. Syst. Mamm. p. 470, sp. 10.

Mustela melanorhyncha, Bodd. Elench. anim. p. 88 , sp. 13.

This is probably a large variety of the preceding, it is an inhabitant of North America. 
'Total length, twenty-four inches; length of the tail, seventeen inches; ears broad, round, blackish and bordered with white; nose black; whiskers long and silky; face and sides of the neck of a pale brown, or cinereus mixed with black; back, belly, thighs, and tail black, but the base of the last brownish; the sides of the body brown; the feet are broad and very hairy; a nail is often wanting on the hind foot; the nails are sharp, arched and white; tail covered with long hairs.

\section{Species.}

6. Muslela martes, Linn. Erxleb. Bodd. Schreb. tab. 130. La marte, Buff. hist. nat. t. 7. pl. 22. The martin, Penn. Brit. Zool. p. 39.

Mustela vison, var. Warden, hist. of the United States, vol. v. p. 613. Pine martin, Sab. append. to Franklin's Exped. (Encycl. pl. 81. fig. 4.)

Char. Essent. Colour brown, with a clear yellow spot beneath the throat.

Dimensions. Total length without the tail, one foot six inches eight lines; of the trunk of the tail nine inches nine lines; of the head, three inches ten lines; height before, eight inches; behind, ten inches.

Description. Fur formed of two sorts of hair; the first large, strong, and long, cinereus next the body, then clear fawn, terminated by brown mixed with shining red; the second consists of a 
fine down, very abundant, not entirely covered by long hairs of a cinereus colour, slightly tinged with white and fawn; end of the snout; breast, the legs and tail, of a blackish brown, in which there is but very little fawn colour; posterior part of the belly, red; borders and interior of the ear whitish, lightly tinged with yellow.

Напіт. Preferring for their haunts the thickest forests; climbing trees in search of birds and their eggs; they also attack small quadrupeds; bringing forth in spring, two or three young at a birth, in the nest of a squirrel or in holes of trees.

Inhabit all the north of Europe and America; liave been observed as far south as New England.

\section{Genus.}

Mephitis, Cuv. Illig.

Viverra, Linn. Gmel. Bodd.

Chaticters.

Dental formula.-Teeth $32 .\left\{\begin{aligned} \text { superior 14. }\left\{\begin{array}{l}\text { Incisor } 6 . \\ \text { Canine 2. } \\ \text { Molar 6. }\end{array}\right. \\ \text { inferior 18. }\left\{\begin{array}{l}\text { Incisor } 6 . \\ \text { Canine 2. } \\ \text { Molar 10. }\end{array}\right.\end{aligned}\right.$

Second inferior incisors on each side, out of the range, inclining towards the interior of the mouth.

Canines very strong, conical.

Two false molars above, and three below on each side.

The superior tuberculous teeth very large, and 
as broad as they are long; inferior molars furnished with two tubercles on the internal side.

Head short; nose rather projecting; snout obtuse.

Tongue smooth.

Feet pentadactyle, with their palms and soles hairy; toes of the anterior feet, armed with robust nails, arched and proper for digging, nails of the hind feet slightly raised when walking.

Trunk of the tail of moderate length, or very short.

Hair of the body and of the tail often very long; particularly that of the latter.

No caecum.

Anal glands secreting a liquor excessively fetid. No follicules near the organs of generation.

HABIT. Burrowing in the earth; feeding on small live animals; diffusing, particularly when disturbed, a most nauseous, detestable odour, proceeding from the liquor of the anal glands, which they mix with the urine; with this fluid they wet the tail, and scatter it to a considerable distance.

Inhabits America, and the Isle of Java; those of the latter country have short tails.

A great variety of these animals has been desciibed by M. Cuvier, some of which may hereafter prove distinct species. The following is the species common in North America. 


\section{Species.}

1. Mephitis americana.

Mustela americana, Desm. Mamm. p. 186. (Encycl. pl. 86, fig. 3, le chinch, fig. 2. Le conepate.)

Var. K. Moufette pole cat, Cuv.

Pole cat or putois of Kalm, (voy. p. 452.)

Skunk of the Americans.

Char. Essent. General colour of the animal, blackish-brown; a large white spot on the occiput; hairs on the tail long and bushy, white at the extremity; claws of the fore feet strong, and about the length of the palm.

Dimensions. Total length one foot six inches; tail nearly the length of the boty.

Habit. Living near the habitations of man; committing depredations on the poultry, \&c. destructive to small animals. In summer they live in rabbit holes, where they collect their provisions. The female brings forth in spring, five or six at a birth. 'They have been observed to dwell for months near to farm houses, without emitting any odour, provided they be not disturbed.

Inhabits North America, abound in the Atlantic states; there are many varieties, differing in colour and markings. (Several prepared specimens in the Philad. Museum, Nos. 65, 649, \&c.)

Genus.

Lutra, otter, Rai. Briss. Scop. Erxleb. Cur. Shaw, Lacep. Illig. Desm. 
Mustela, Linn. Gmel.

\section{CIIARACTEHS.}

Dental formula.-Teeth $36 .\left\{\begin{aligned} \text { superior 18. } & \left\{\begin{array}{l}\text { Incisor } 6 . \\ \text { Canine } 2 . \\ \text { Molar } 10 .\end{array}\right. \\ \text { Linferior 18. } & \left\{\begin{array}{l}\text { Incisor } 6 . \\ \text { Canine 2. } \\ \text { Molar } 10 .\end{array}\right.\end{aligned}\right.$

The second inferior incisor of each side a little receding in some species; canines of moderate length and hooked; the first superior molar small, blunt, and sometimes deciduous; the second cutting; the third of similar form but thicker; the fourth of moderate thickness, with two external points, and furnished with a strong spur on the inner side; the fifth has three small points externally, with a broal spur internally; inferior molars vary from five to six, the first being often wanting; in other respects they resemble the superior.

Head broad and flat; tongue slightly papillous; ears short and round; body very long and low upon the legs; toes armed with hooked nails, not retractile, and united by a membrane proper to facilitate natation.

Tail not so large as the borly, strong, and depressed at its base; body covered with two sorts of hair, a fine soft down, and long brilliant bristles. Two small glands secreting a fetid liquor, situated near the anus.

Habit. Carnivorous like the martins, but liv- 
ing almost exclusively on fish; residing in holes on the banks of rivers or beaches.

\section{Species.}

Lutra brasiliensis, Rai. Geoff. Desm. (Encycl. pl. suppl. 5, fig. 3.) Mustela lutris brasiliensis, Linn. Gmel. Saricovienne de la Guyane, Buffon, suppl. tom. 6. p. 28\%. Lutra canadensis, Sabine.

Loutre d'Amerique, Cuv. regn. anim. tom. 1. p. 151, et tom. 4, fig. 3. American otter, Philadelphia Museun, No. 701, from Delaware state.

Char. Essent. General colour reddish-brown, with the throat white or yellowish.

Dimensions. Total length, three feet two inches; length of the head, six inches; of the tail, one foot five inches; medium height of the body, ten inches.

Description. Head globular; neck very long; hair rather short, of a reddish-brown, lying flat to the body; mole sparse upon the tail; tail brownish, darkest towards the end ; body beneath of the same colour with the back; lower jaw and throat of a dirty brown, slightly tinged with yellow.

Haвiт. They form groupes more or less numerous, and frequent rivers and fresh water marshes; feeding on fish.

Inhabit la Guyane, and some parts of North America. Specimen in the Philadelphia Museum.

Species.

2. Lutra marina, sea olter. Erxleb. Desm. 
Mustela lutris, Linn. Gmel.

Loutre du Kamtchatka, Geoff. Encycl. pl. 79. fig. 3.

Char. Essent. Body very much elongated; tail equal to one-third the length of the body; hind feet very short; the animal of a lively blackish colour.

Dimensions. Total length two feet ten inches; length of the tail nine or ten inches; weighing from seventy to eighty pounds.

Description. Head small and globular; ears straight, conical, and covered with hair; eyes rather large; iris varying from brown to black; a nictitating membrane at the internal angle of the eye, extending over nearly one half the globe; nostrils black and wrinkled; lips thick; opening of the mouth, wide; superior jaw armed with fourteen teeth, four of which are sharp incisors; one canine on each side, and four or five large thick molars, the first cutting, and the last furnished with blunt tubercles; one molar additional in the lower jaw ; tongue rather long, slightly notched at the extremity, covered with comeous papillæ; legs and thighs short, and placed nearer to the anus than in other quadrupeds, except in the seals; toes united by a hairy membrane, and terminated by a hooked claw; tail thick and depressed; fur vich, generally black or brownish. 
Variety. L. marina, with a white head, Dict. des Science, Nat. fascic 7, p. 19.

Habiт. During the winter residing sometimes upon the ice, at others, on the borders of the sea; occasionally following the courses of rivers even up to fresh water lakes; living in pairs; the female brings forth but one at a time, after a gestation of eight or nine months ; feeding on crustacea, shells, sea worms, fish, fruits cast on shore during the summer, fuci, \&c.

Inhabit the coasts of North America, particular$1 y$ the north-west of this continent; they exist also on the eastern coast of Kamtchatka, and neighbouring islands. This animal is hunted for its skin, which is very valuable.

The Canada otter, (Mustela hudsonica, Lacep.) is probably the same animal.

\section{Genus.}

Canis, Limn. Briss. Penn. Erxleb. Bodd. Cur. Geoff. Illig. Desm.

CHARACTERS.

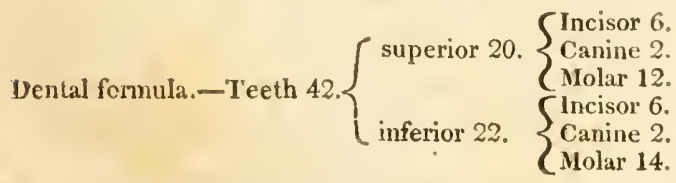

Incisors placed in a regular series, trilobate, when they have not been used; canines conical, sharp, and smooth; superior molars to the num- 
ber of six on each side, viz. three small sharp teeth or false molars with cutting edges, single lobed; a bicuspid molar, and two small teeth with flat crowns; the penultimate with two sharp tubercles on the exterior side.

Inferior molars seven, viz. four small molars, one molar with a blunt point on the posterior part of the crown, and two tuberculous teeth; jaws elongated; zygomatic processes moderately arched externally.

Snout pointed, a considerable portion of the extremity naked and rounded; tongue smooth.

Ears nearly straight and pointed, (in a state of nature.)

Fore feet pentadactyle; hind feet tetradactyle, provided with elongated nails, rather obtuse, not retractile; tail of various lengths, generally straight, (in a state of nature.)

Mammæ placed upon the breast and abdomen.

Habiт. Onnivorous; voracious; very intelligent; for the most part uniting in troops in order to hunt down the more peaceable animals on which they prey; pursuing them by means of their sense of smell, which is very delicate from the great development of the schneiderian membrane; seeing and hearing at a great distance; the female, in a savage state, bringing forth from three to five at a birth, which they nurse with great affection, and defend with courage; some species burrow in the earth, occasionally occupy- 
ing the retreats of other animals ; but the greatest number establish their retreat in the thickest forests, \&c. \&c.

Inhabit all parts of the habitable globe, with the exception of some groups of islands situated in the Pacific occan.

\section{Species.}

1. Canis familiaris, Limn. Erxleb. Bodd. Desm. p. 130. Encycl. pl. 98, fig. 3. pl. 99, 100-1, 2, 3, 4. Le Chien, Buff. hist. Nat. tom. 5.

The Dog, Penn. Brit. Zool. p. 23.

Char. Essent. Tail recurved; nose more or' less elongated or contracted; nature and colour of the hair various, with the exception that whenever the tail offers the mixture of any colour with white this white is always terminal. This fact has been lately verified in a number of instances by Desmarest, who has lately observed it in several of the more savage species, as the antarctic dog, which has induced him to believe this last named variety to be nearest to the original.

We have very little doubt that the various species of domestic dogs are mere varieties of prolific hybrids, produced by the union of the wolf, ( $\boldsymbol{C}$. lupus) with the fox, (C. vulpes) or jackall, (C. aureus ;) which opinion was originally advanced by Pallas. A prolific hybrid of this kind once produced, the progeny would more readily unite with the congeners of either parent, and with each 
other, and in this manner give rise to the immmerable varieties which at the present day are found scattered over the face of the earth: thus the domestic dog of the North American Indians, bears a strong resemblance to the wolf, not only in its erect and pointed ears, general colour of its body, \&c. but this resemblance is further traced in the construction of the cranium and teeth, which partake in some degree both of the dog and wolf; in the former the jaws are less elongated, and display a greater breadth posteriorly; the molar teeth on each side of both jaws being more widely separated; the zygomatic fossæ are less capacious; the surface for the attachment of the temporal muscle less extensive, and the forehead considerably more elevated in the Indian dog; the facial angle of the prairy wolf is twenty six degrees, that of the Indian dog, thirty-five. These differences are yet more obvious when we compare the cranium of the common domestic dog with that of the wolf.

The same observations will apply with nearly equal force to the domestic dog of the East Indies; with this difference, viz. in the latter there exists a strong resemblance to the Jackall, to which also it is further allied in its howl, and other less observable particulars; indeed a successful union of the dog and jackall has repeatedly taken place.

In corroboration of the above, we may add that 
prolific hybrids have been produced by the union of animals generically distinct, between the martin, (Mustela martes) and the domestic cat. An account of which is published in one of the early numbers of the New Edinburgh Philosophical Journal.*

* Mr. Sabine states, that during Parry's expedition to the North Pole, the dogs pertaining to the ship, were observed to copulate with the savage wolf; which circumstance he conceives as a convincing proof of identity of species; but the same argument would apply almost equally to prove the identity of the $\log$ and hog.

We are indebted to the late Dr. B. S. Barton, for some very interesting observations concerning the native North American dogs.

"The Indian dog is frequently called by the traders and others, 'the half wolf breed.' His general aspect is much more that of the wolf than of the common domesticated dogs. His body, in general, is more slender than that of our dogs. He is remarkably small behind. His ears do not hang like those of our dogs, but stand erect, and are large and sharp pointed; he has a long, small snout, and very sharp nose; his barking is more like the howling of the wolf. When attacked, and when lighting, he does not shake his antagonist like our dogs; his teeth are very sharp, and his bite sure; when he suarls, which he is wont to do upon the slightest occasion, he draws the skin from his mouth back, presenting all his teeth to view. Our dogs when once attacked by these Indian dogs, always fear and shun them. It is a very curious circumstance, that the Indian dog will never attack or pursue the wolf, which the common dogs so readily do; this fact seems to point very strongly to the origin of the American animal. For the purpose of hunting, the Indian dogs are very useful; but in other respects, they are by no means so docile as the common dogs; they have less 
Desmarest, in his "Mammalogie," includes all the varieties of this species under three grand divisions.

"1. Les matins. Head more or less elongated; parietals approximating: condyles of the lower jaw on a line with the superior molars.

“2. Les espagneuls. Head moderately elongated; parietals not approximating from their commencement above the temporals, separating on the contrary, and expanding so as to increase the cerebral carity and frontal sinuses.

"3. Les dogues. Snout more or less shortened; cranium elevated; frontal sinuses considerable; condyles of the lower jaw placed above the line of the superior molars."

In detailing the characters of the common bull dog, (Canis molossus, Linn. Gmel.) he omits one of the most principal traits, viz. in this variety, the inferior incisors and the lower jaw project beyond the superior teeth and jaw.

For a detailed account of the varieties of the domestic dog, see F. Cuvier's papers, published in the anal. du mus. d'hist. nat.

\section{Species.}

2. Canis lupus, common wolf, Linn. Erxleb.

fidelity. In short, every thing shows that the Indian dog is a much more sarage or imperfectly reclaimed animal than the common dog.:**

* Vide, Barton's Medical and Physical Journal, vol, 1, part 2, page 13. 
(Encyel. pl. 104. fig. 3.) Schreb. Bodd. Le lonp, Buff. hist. nat. tom. 7. pl. 1.

The wolf, Penn. syn. Quad. p. 149. No. 3.

Char. Essent. 'Tail straight; general colour reddish-gray, with a black ray on the fore legs of adults ; eyes oblique.

Dinevsions. Total length, three feet seven inches; length of the head, ten inches; of the ear, four inches six lines; of the trunk of the tail, one foot three inches four lines; greatest height of the anterior part of the body, two feet five inches; behind, two feet three inches.

Description. Head thick and oblong, terminated by a slender snout; tail thick, tufted, and straight; coat composed of hairs, the longest of which are white at base, then black, then reddish, then black and white at the extremity; those of the head anterior to the opening of the ears, those of the neck and anterior part of the back, of the buttocks, and of the tail, being longest, measuring even five inches; the others much shorter, principally on the snout and ears; all these hairs being stifl and strong, covering a soft cinereus felt; an oblique black band on the wrist in adults ; snout black:

The hair of wolves grows white by age, and wolves of northern latitudes become white in winter.

Habir. Solitary, dwelling in thick forests; prowling at night: attacking generally the sheep. 
antelope, deer and hare: they also feed on carrion, which they smell at a great distance; they are cunning, distrustful, and intelligent, but much less so than the fox. During the winter, when pressed by famine, they unite in troops in order to attack the larger animals. The female enters in heat during the winter, in which state she continues twelve or fifteen days; she brings forth in the most secret recesses of the forest, after a gestation of sixty-three days, five or six young at a birth, whose eyes are closed, as is the case with dogs. The wolf attains its maturity about the end of the second year, and lives fifteen or twenty years; its voice is a prolonged howl. The dog is generally its enemy, nevertheless instances are numerous of sexual union between the two species, producing a prolific hybrid, partaking more of the nature of the wolf than dog.

Inhabits Europe, southern Africa, North America: the race is totally extirpated from England and Ireland.

Mr. Warden, in his description of the United States, vol. 5. p. 615, says, there is a great variety of wolves in this country, both as regards their size and colour. In the northern states this animal is red or reddish-brown, with a blackish line along the spine, and yellow rays about the ears and on the arms; in the southern states the wolf is entirely black.

In the Missouri comntry we observe several 
new species or varieties; one of large size and brown colour was seen in the mountains near Columbia river, between the Great Falls and Rapids; (perhaps the Canis mubilus, Say, to be described hereafter?) Another is found on the borders of the Pacific ocean, which burrows like the fox. (This has not been described.) 'Two other smaller species inlabit woodlands, and show themselves occasionally in the plains; (perhaps Canis latrans, Say?)

Mackenzie mentions a little wolf he met with between the sixty-fifth and seventieth degrees of north latitude, which attacks the beavers.

\section{Species.}

3. Canis lycaon, Limn. Gmel. Erxleb. Schreb. Loup noire, Buff. hist. nat. v. 9. pl. 41, and Encyc. pl. 104. fig. 4.

Char. Essent. Tail straight; body totally black.

Dinensions. Intermediate between those of the common wolf and fox.

Description. Resembling the common wolf in form and proportion, but the eyes are rather smaller, and ears longer; hair entirely black.

The black wolf of Florida, of which Bartram speaks as having a white spot on the breast (in the female, ) is mentioned as a variety of the $C . l y$ caon, by Warden.

Gmelin and Erxleben, have erroneously ap- 
plied to the Canis lycaon, citations which relate to the gray fox of North America.

Inhabits mountainous countries of Europe and North America.

\section{Species.}

4. Canis latrans, Prairie wolf, Say. Long's exped. to the Rocky Mountains, vol. 1. p. 168.

Char. Essent. Hair cinereus gray, varied with black above and dull fulvous cinnamon, and at tip gray or black; longer on the vertebral line.

Dimensions. Total length, including the tail, with the exception of the hair at its tip, three feet nine and a half inches; trunk of the tail, one foot one and a half inches; length of the ears, four inches; length of the fore leg, one foot.

Description. Hair at base, dusky plumbeous, in the middle of its length, dull cinnamon, at tip, gray or black; ears erect, round at tip, cinnamon colour behind; dark plumbeous at base; inside lined with gray hairs; iris yellow; pupil dark blue; lips white; three series of black setæ; sides paler than the back, obsoletely fasciate with black above the legs; legs cinnamon colour on the outer side; a dilated black abbreviated line near the wrist; tail straight, bushy, fusiform, varied with gray and cinnamon, tip black.

Навіт. They are by far the most numerous of our wolves; roaming over the plains in numbers during the night; hunting the deer; sometimes 
reduced by hunger to eat the wild plums, and other fruits, to them almost indigestible; their bark resembles the dog at first, but terminates in a lengthened howl; these animals are remarkably intelligent.

Inhabit the plains of Missouri, and other regions west of the Mississippi, and not improbably west of the Rocky Mountains.

This is certainly a distinct species from the "Canis mexicanus," (Desm. Mamm. p. 199) to which it is most nearly allied; the essential characters of the latter are "general colour cinereus, varied with reddish spots; many blackish bands extending on each side of the body from the spine to the flanks." "Inhabits New'Spain."

Mr. Say thinks the "latrans" most probably the origin of the domestic dog, so common in the villages of the Indians of this region, some of which still retain much of the manners and habits of this species. (Beautiful prepared specimens in the Philadelphia Museum, brought by the exploring party.)

Species.

5. Canis nubilus, dusky wolf, Say. (Long's Exped. to the Rocky Mountains, v. 5. p. 169.)

Char. Essent. General colour dark dusky; the hair cinereus at base, then brownish, then gray, then black; the proportion of black on the hairs is so considerable as to give to the whole 
animal a much darker colour than the darkest of the latrans, but the gray of the hairs combining with the black tips, in the general effect, produce a mottled appearance; the gray colour predominant on the sides.

Drmersions. Length from the tip of the nose to the origin of the tail, four feet three inches and three quarters; length of the trunk of the tail, one foot three inches; of the ear, from the anterior angle to the tip, three inches and three quarters; from the anterior angle of the ear to the posterior canthus of the eye, four inches and three quarters; from the anterior canthus of the eye to the tip of the nose, five inches and a half; between the anterior angles of the ears, rather more than three inches.

Description. Ears short, deep brownish black, with a patch of gray on the anterior side within; muzzle blackish above; anterior border of the superior lips gray; tip of the inferior jaw, gray, a line of the same colour extending backwards nearly to the origin of the neck; beneath dusky ferruginous, grayish, with long hair between the hind legs; a large white spot on the breast; the ferruginous colour narrowed on the neck, and dilated on the lower part of the cheeks; legs brownishblack; tail short, fusiform, slightly tinged with ferruginous, black above near the base and at tip; the longer hairs on the back, particularly over the shoulders, resemble a short sparse mane. 
The aspect of this animal is far more fierce and formidable than either the common red wolf or the prairie wolf, and is of a more robust form. The length of the ears and tail distinguish it at once from the former, and its greatly superior size, besides the minor characters of colour, \&c. separate it from the prairie wolf.

It diffuses a strong and disagreeable odour.

Habit: Unknown. Inhabits the same countries as the preceding species.

\section{Fox.}

Pupil taking the figure of the section of a lens, in closing.

\section{Species.}

6. Canis vulpes, common fox (Encycl. pl. 106, fig. 2.)

Char. Essent. General colour reddish above, and white beneath; behind the ears black; tail tufted and terminated by black hairs.

Dumensions. Total length, two feet three inches six lines; length of the head, three inches; of the ears, four inches; of the tail, one foot four inches; height of the body before, one foot one inch three lines; height of the body behind, one foot two inches three lines.

Description. Snout pointed; head rather large; forehead flattened; ears straight, pointed; eyes very oblique; tail large, touching the ground, ex- 
tremely bushy; feet composed of long and thick hairs, of a more or less deep red; lips, borders of the mouth, lower jaw, anterior of the neck, throat, belly, interior of the thighs, white; snout red; behind the ears of a black-brown; feet deep brown before; tail terminated with black hairs.

Var. 1. C. alopex, (Linn.) Var. 2. Canis crucigera, (Gesner.)

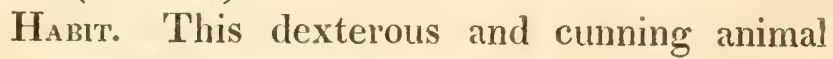
lives in the woods near the dwellings of man; during the night committing depredations upon poultry; first killing all within his reach, then carrying them to his hole, or burying them beneath the leaves; he also destroys rabbits, and birds, and robs the snares of the hunter, is fond of eggs, milk, and fruit, particularly of grapes, will occasionally attack bee hives, and does not refuse fish, insects, \&c. 'The female enters into heat during the winter; produces once a year, five or six at a birth, seldom less than three: the young attain their full growth in about eighteen months. The duration of their life is about fourteen years; their voice is a species of barking; produced by a reiteration of precipitate similar sounds. The fox emits a disagreeable odour. In cases of extreme danger and surprise these animals have been known to simulate death.

Inhabit northern and temperate climates of both continents. 


\section{Species.}

\section{Canis argentatus, Geoff. Desm.}

Renard argentè ou noir, Geoff. collect. du Mus. Renard argentè, F. Cuvier. Mamm. lithogr. 5 livr.

Char. Essent. General colour soot-black, spotted, or rather brushed with white; extremity of the tail, white.

Dinensions. Total length, one foot five inches; length of the head, six inches; of the tail, eleven inches; height before, one foot one inch; behind, one foot two inches.

Description. Form of the common fox ; colour black, sometimes slightly tinged with white in some parts; extremity of the tail for the most part perfectly white; hair silky, thick and fine; feet and snout covered with short hair; eyes yellowish; sometimes a white spot beneath the neck.

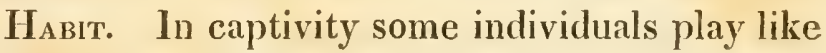
dogs, growling like these animals; they hide their superabundant food and dislike the heat.

Inhabit the north of Asia and America. M. F. Cuvier doubts the identity of the European and American species.

\section{Species.}

8. Canis decussatus, Geoff. collect. du Mus.

Char. Essent. Colour varied with black and white above, with a black cross upon the should 
ers: snout, inferior parts of the body and feet black; tail terminated with white.

Dimensions. Same as the European fox.

Inhabits North America-may possibly prove to be a variety of the argentatus.

\section{Species.}

9. Canis virginianus, gray fox of Catesby, nat. hist. Carolin. v. 2. p. 78. Briss. regn. anim. Canis virginianus, Erxleb. Gmel. (Encycl. pl. 106. fig.4.)

Char. Essent. Body entirely of a silver gray colour.

Dimexsions and Description. Differing very little from the European fox in size and form. Some doubt has been expressed concerning the identity of this species and the "Fulvus," described below. A comparison of the skulls of the red and gray American fox, presents prominent specific distinctions, as has been demonstrated by frequent examination.

\section{Species.}

10. Canis fulvus, (renard de Virginie, Palisot de Beauvois. Mem. sur le renard et le Lapin d'Amerique, dans le Bull. Soc. Philomat.)

Canis fulvus, Desm. Mamm. p. 203.

Char. Essent. Colour consisting of different shades of red; beneath the neck and belly, white; breast gray: anterior of the fore legs and feet black; tip of the tail white. 
Dimensions. Total length, not including the tail, two feet two inches.

Description. Snout obscure red; forehead and cheeks more clear; borders of the lips, white ; interior of the ears, covered with yellowish-white hair; exterior black; top and sides of the neck, shoulders, and fore feet, a lively red; tail varied with black and red, extremity white.

\section{Species.}

11. Canis cinereo-argenteus, tricoloured fox, Erxleb. Linn. Gmel. Renard gris, Briss. Quad. p. 241.

Char. Essent. Upper part of the body, black gray; head reddish-gray; ears and sides of the neck a lively red; throat and cheeks white; inferior jaw black; belly and tail reddish, glazed with black; tip of the tail deep black.

Dimensions. Total length, two feet two inches; trunk of the tail, one foot one inch.

Description. Between the eyes whitish, divided by a black longitudinal line, which is lost upon the forehead; superior lip white; borders of the lips black; beneath the eye an obscure spot, which extends along the cheek nearly to the neck; tail very bushy, covered with hairs about three inches in length.

Inhabits North America and Paraguay. 


\section{Species.}

12. Canis velox, Say. (Long's Exped. to the Rocky Mountains, v. 1. p. 486.)

Char. Essent. Head above ferruginous-brown, intermixed with gray; fur fulvous; hair whitish at base, then black, gray, and brown in succession.

Dimensions. Total length of the animal not more than one half that of the red fox, (C. fulvus, Desm.) length of the cranium, four inches threetenths; distance between the tips of the superior orbitar processes, one inch; between the temporal crests at the coronal suture, half an inch.

Description. The hair is fine, dense and soft; a brownish dilated line passes from the eye nearly to the nostrils; margin of the upper lip, white; orbits gray; margin of the ears, excepting at tip, white; the inner side broadly marginated with white hairs; the neck above has longer hairs, of which the black and gray portions are more conspicuous; beneath the head, pure white; the body slender, and tail rather long, cylindrical and black.

H $_{\text {ABIT. Th }}$ Thistle animal runs with extraordinary velocity, so much so, that when at full speed its course has been by the hunters compared to the flight of a bird. Like the corsac of Asia, it burrows in the earth, in a country totally destitute of trees and bushes, and is not known to frequent forest districts. 
Inhabits Missouri country; is probably the same animal mentioned by Lewis and Clark, under the name of burrowing fox, vol. 2. p. 351.

\section{Species.}

13. Canis lagopus, isatis fox, Linn. Gmel. Erxleb. Bodd. Renard bleu. Buff. C. lagopus, Sabine. append. p. 658. (Encycl. pl. 106. fig. 3.)

Char. Essent. Hair very long, thick and soft; fur cinereus, or of a uniform clear brown in summer; white in winter.

Dimensions. Total length from twenty-two inches to two feet; tail reaching to the ground; about one foot high before.

Description. Head short; snout elongated; ears hairy; soles of the feet covered with long hairs ; tail long and very bushy ; hairs of the body, about two inches in length, of a cinereus or uniform clear brown colour, changing to a beautiful clear white in winter. 'The young animal is sometimes of a dark gray colour, sometimes yellowish-white; occasionally marked with a brown line upon the back and a transverse line of the same colour upon the shoulders, on which ac. count they have been called the crucial fox, a name already applied to a species of fox properly so called.

HaBIT. Living in the coldest countries of the earth, in mountainous districts, but not in forests. They enter in rut during the month of March, 
which state continues about fifteen days, and gestation about nine weeks; its voice is between that of the fox and dog, its skin is very precious.

Inhabits the countries bordering on the frozen ocean in Iceland, Greenland, and the continent of America, according to Sabine.

\section{Gemus.}

Cat, or Felis. Linn. Briss. Erxleb. Bodd. Cuv. Geoff. Illig.

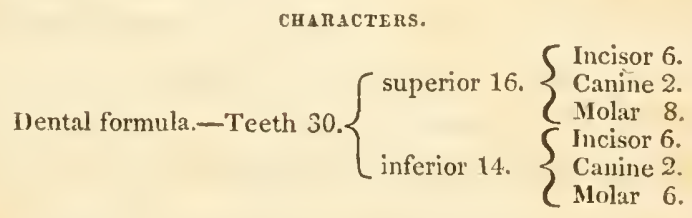

Inferior incisors, forming a regular series. Canine, very strong. Four molars above, viz. two false or conical on each side; one carnivorous, with three lobes and a small tuberculous tooth, wider than long, (the last sometimes wanting, below, on each side, two false, compressed, simple molars, and one carnivorous bicusped. Head round: facial line short, and slightly arched; zygomatic arches ventricose; jaws short; tongue covered with corneous papillæ, their points directed backwards; nose terminated by a very small muzzle, with the nostrils pierced inferiorly and at the sides ; ears short, straight, triangular; pupils contracting sometimes in a vertical line, sometimes 
in a circle; legs proportionably short; anterior feet pentadactyle, posterior tetradactyle; nails of the fore feet retractile, in a state of repose, elevated and lying obliquely between the fingers; tail more or less long; no pouches or follicles around the organs of generation or anus; glans of the male covered with small corneous papillæ.

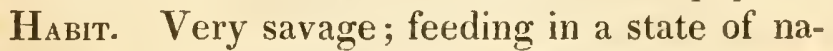
ture on living animals only, which they seize by surprise and not by chasing, as the dogs are accustomed to do; leaping and climbing with facility; running badly; sense of smell not very acute, but that of sight very perfect.

Inhabit the forests of various climates; none have been discovered in Australasia.

\section{Species.}

1. Felis concolor, Linn. Gmel. Bodd. Erxleb. (Encycl. pl. 94. fig. 1. and 2.) Le cougar, Buff. v.9. pl. 19. Gouazoura, d'Azara, nat. hist. Parg. v. 1. p. 133. Pouma of travellers, vulgarly called the American Lion.

Char. Essent. Of a deep yellow colour, without a mane or tuft at the end of the tail.

Dimensions. Total length, three feet six inches; length of the tail, two feet three inches; of the head, seven inches nine lines.

Description. Body long and slim; head small; legs strong, short; tail long and training; colour, grayish about the eyes; hairs within the ears white, 
slightly tinged with yellow, exterior of the ears blackish; those portions of the lips which support the whiskers, black; the remaining portions of the lip, with the throat, white: beneath the neck, pale yellow.

Note.-The "Cougar de Pennsylvanie," Buft. (hist. nat. suppl. 3. tom. 2. pl. 41.) is most probably a variety. Collinson remarks, that it is lower upon its legs and has a longer tail than this; it is described as being five feet six inches in length; tail, two feet six inches; height before, one foot nine inches; behind, one foot ten inches.

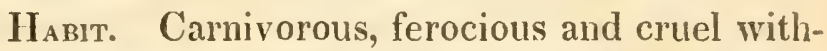
out necessity ; attacking principally sheep, goats, calves, and colts; living isolated or in pairs, in the depths of forests; leaping with agility and climbing trees with facility.

Inhabit Paraguay, Brazil. United States, as far north as Canada.

Species.

2. Felis onca, Jaguar, (Encycl. pl. 92. fig. 2. by the name of Panther.) Yagouarètè, d'Azara, Fred. Cuvier, Mamm. 17 livr. Onza Marcgrave.

Panthere femelle, Buff. tom. 9. pl. 12.

Char. Essent. Colour yellowish above, white beneath, marked with circular black spots, ranged in five or six lines on each side of the body. 
Dimensions. 'Total length, four feet seven inches; length of the tail, two feet two inches; height of the body, two feet six inches.

Description. Proportions thick and clumsy; hairs short, strong, compact, silky, and rather longer on the inferior parts of the body; base of the fur yellowish, and covered with spots either entirely black, or yellow encircled with black; those of the first sort existing only on the head, tail, extremities and under part of the body; interior of the ear, white; exterior black, with a white spot; commissure of the lips, black, as is also the end of the tail; four mammæ.

$\mathrm{H}_{\text {ABIT. Living in swampy forests; retiring into }}$ dens during the day; they are very fierce, will attack dogs and destroy large domestic animals; they climb trees like cats; bringing forth two young at a birth.

Inhabit Brazil, Paraguay, Mexico and United States, (south-western territory, occasionally found east of the Mississippi.

\section{Species.}

3. Felis pardalis, Linn. Erxleb. Bodd. Ocelot, Buff. hist. nat. t. 13. pl. 35. No. 36. Shaw, Gen. Zool. v. 1. part. 1. pl. 88. fig. (Encycl. pl. 93. fig. 2.) Spotted mountain cat.

Char. Essent. General colour gray, marked with large fawn coloured spots, bordered with 
black, forming oblique bands on the flanks; two black lines bordering the forchead laterally.

Dinersions. Nearly two feet in length from the extremity of the snout to the origin of the tail, which is about two feet long.

Description. Snout longer and thicker than that of the cat; hairs sparse, grayish fawn above, white beneath; a black line extending on each side, from the nostril to the anterior angle of the eye, and prolonged on the head as far as the occiput, by the side of the ear; small black spots disposed symmetrically between these bands, upon the forehead and head; other small round black spots where the whiskers commence; two rays along the sides of the lower jaw, one above the other, the superior commencing at the posterior angle of the eye, the inferior having two branches before, the lower one directed towards the throat; four longitudinal bands on the top of the neck, of a fawn colour in the middle, the two external ones curved downwards in form of a hook; a small black line between the two middle ones, a black line along the back extending to the origin of the tail, on each side of which is a parallel row of oval black spots, about one inch in length; two other bands also parallel, composed of oval figures, with black borders, and fawn colour in the middle with small round black spots; beneath the third row is a band of more than an inch in width, extending from the shoulders to before the thighs, 
bordered with black, like the oval figures, and fawn colour in the middle, with small round black spots; and lastly a band beneath the latter rather less broad and interrupted; bordered spots on the rump and thighs; small oval full spots on the anterior part of the shoulders and on the thighs, also on the anterior surface of the paws; transverse lines beneath the neck, one of which extends from one side to the other, in form of a collar; breast and belly with small black spots ; tail marked with spots of the same colour, much larger towards its extremity; (a specimen of the adult, and,very young animal, in Philadelphia Museum.)

Habit. Similar to that of other species of this genus; climbs trees with facility.

Inhabit Mexico, and the south-western parts of the United States, particularly Louisiana; also observed by Mr. Nuttall in the Arkansa territory; vid. 'Travels into the Arkansa territory, p. 118. Not known to exist east of the Mississippi.

\section{Species.}

4. Felis canadensis, Geoff. Desm. Le lynx du Canada, Buff. hist. nat. suppl. tom. 3, pl. 44. Lynx.

Char. Essent. Tail very short, black on the posterior half; ears terminated by a small pencil of hairs ; colouring of the body grayish, with yellowish or pale brown points below, some black lines on the head. 
Dimensions. Total length, two feet three inches; of the tail, three inches nine lines; of the ears, two inches.

Description. Differing from the Lynx properly so called, in the shortness of the tail; body covered with long grayish hairs, mixed with white, spotted and striped with yellow, more or less deep; head grayish, mixed with white and yellow, slightly striped with black in some places; end of the nose and borders of the lower jaw, black; whiskers white, about three inches long; ears furnished with long white hair within, mouse gray externally, external border black, internal border yellowish; pencils of the ears composed of black hairs about seven or eight lines in length; tail short and thick, well furnished with hair, first half reddish-white, last half black; abdomen, hind legs, interior of the fore legs, and end of the feet, of a dirty white; nails white, about six lines in length.

Inhabit Canada, Labrador, \&c.

\section{Species.}

5. Felis rufa, Guldenstaedt, Gmel. Schreb. Rafinesque, Ame. Mon. Mag. 1817, p. 46, sp. 3. "Chat-cervier," of furriers.

Char. Essent. Tail short, white beneath and at the point; ears furnished with a pencil of hairs; colour dark or reddish yellow, spotted with brown. 
Dinensions. Rather smaller than the common Lynx.

Description. Head and back, of a deep red, with small spots of blackish-brown; throat whitish; breast and belly of a clear reddish-white: extremities of the same colour with the back, with waves of light brown; superior lip presenting some blackish lines upon a reddish-white ground; a little white about the eye.

Inhabit the forests of New York, Pennsylvania. and Ohio.

\section{Species.}

6. Felis fasciata.*

Lynx fasciatus, Rafinesque, Ame. Mon. Mag. 1817, p. 46. Lewis and Clark's expedition up the Missouri.

Char. Essent. Tail rery short, white, with the point black; ears furnished with pencils of hair, and black externally; fur very thick, of a brownish-red colour, with blackish stripes and points above.

Dinensions. Large.

Inhabit North America. This species was noticed by Lewis and Clark on the north-west coast; (where there exist several other species of $L y n x$, remarkable for their size and beauty of fur.) It is probably the same as that mentioned by Nuttall. Vid. 'Travels in Arkansa territory, p. 118. 
Species.

7. Felis montana, (Encycl. pl. 98, fig. 2.)

Lynx montana, Rafin. ibid. p. 46.

Mountain cat, of the Americans.

Lynx du Mississippi, Buff. t. 8, pl. 53.

Char. Essent. Tail very short, grayish; ears destitute of pencils of hair; exteriorly blackish, whitish or yellow spots within; whitish, with brown spots beneath.

Druessioxs. Total length, three or four English feet.

Inhabit New York, Alleghany mountains, and as far south as Florida.

\section{Species.}

8. Felis anrea, Desm.

Lynx aureus, Raf. ibid. p. 46.

Wild cat, Leray, voy. au Missouri, p. 190.

Char. Essent. Tail very short; ears without pencils; colour, a clear brilliant yellow, spotted with black and white.

Dimersions. One half larger than the domestic cat, tail two inches long.

Description. This species simply indicated by Leray; has been observed on the borders of Yellow Stone river, near the forty-fourth degree of north latitude, and thirty-second west longitude, from the meridian of Washington. 
Felis catus, Linn. and others.

Domestic species not indigenous; a variety of the "Chat sauvoge," Wild cat, Buff. hist. nat. tom. 6, the essential characters of which are, base of the fur of a more or less obscure gray; marked with blackish longitudinal bands on the back, and transverse ones on the flanks; lips and soles of the feet black; tail surrounded with rings, the end black.

Inhabits all the great forests of Asia, but are rare.

\section{Tribe.}

CARNIVOROUS AMPHIBIOUS ANIMALS.

(Carnivora pinnipedia.)

Feet short, enveloped in the skin in form of fins; the posterior in the direction of the body; number of incisors variable, often six, and sometimes four above; most commonly four, sometimes two below.

\section{Genus.}

Phoca, Linn. Erxleb. Bodd. Cuv. Geoff. Illig. Otaria, Peron.

1. Those in which the teeth are furnished with several roots.

CHARACTERS.

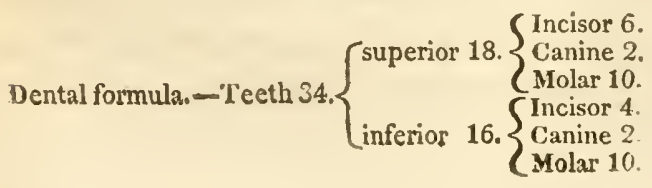


$\Lambda$.

Dental formula.-Teeth 32. $\left\{\begin{aligned} \text { superior 16. } & \begin{array}{l}\text { Incisor } 4 . \\ \text { Canine 2. } \\ \text { Molar 10. } \\ \text { inferior 16. } \\ \text { Incisor 4. } \\ \text { Canine 2. } \\ \text { Molar 10. }\end{array}\end{aligned}\right.$

B.

Dental formula.-Teeth 30. $\left\{\begin{array}{l}\text { superior 16. } \begin{array}{l}\text { Incisor 4. } \\ \text { Canine 2. } \\ \text { Molar 10. } \\ \text { Incisor 2. } \\ \text { Canine 2. } \\ \text { Molar 10. }\end{array}\end{array}\right.$

2 . Those in which the teeth have simple roots.

characters.

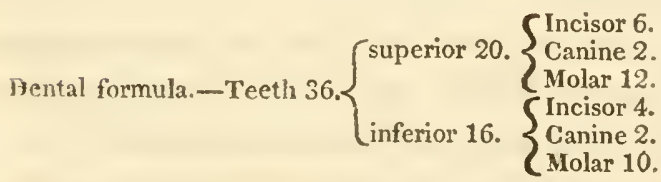

A.

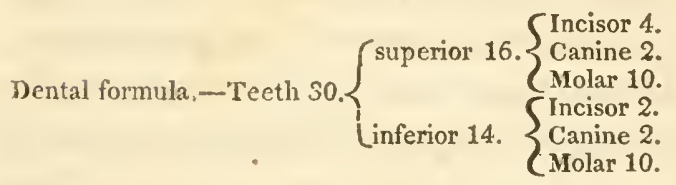

Incisors varying in their forms, sometimes triangular, sometimes conical, sometimes grooved transversely on their cutting edges, as if bilobate, and more or less distinct from each other.

Canines more or less strong, conical, slightly arched, and most generally proportional to the size of the head, like those animals of the feline race. 
Molars resembling the false molars of carnivorous animals, cutting, triangular, but more conical and obtuse; sometimes, though rarely, with little tubercles at their neck.

Head round; snout and lips swollen; nose sometimes prolonged into a species of soft erectile trunk; nostrils susceptible of being completely closed.

Eyes very large, the cornea flat, and the chrystalline lens protuberant; eyelids slightly developed, excepting the nictitating membrane.

Ears wanting altogether, or rudimentary, narrow and pointed.

Tongue conical, papillous, but soft, with the extremity slightly notched; mouth moderately large. bordered by lips susceptible of extension.

Feet five-toed; the anterior displaying externally the hand only; the posterior feet naked: toes slightly distinct, enveloped by the skin which extends beyond them more or less; those of the hand decreasing in length, ordinarily from the internal to the external; the two external of the hind feet the longest.

Tail short and thick, situate between the two hind feet.

Mammæ to the number of four, abdominal; hair in general short, stiff and recumbent; whiskers very strong and abundant; stomach simple, membranous; intestines of equal diameter throughout their length. 


\section{Ciecum small.}

Habiт. Aquatic, visiting the land only for the purpose of copulation, or to bring forth and suckle their young; swimming and plunging with great facility; feeding upon fish, molusca, and sea grass; having the organs of vision constructed for a residence in deep waters; sense of hearing not delicate; that of taste perfect; that of touch obtuse, by reason of the thick layer' of fat which surrounds the animal; but the sense of smell is exquisite.

They travel and live in numerous troops, the greatest harmony prevailing amongst them, except during the rutting season, when the máles engage in furious combats, disputing the possession of females; the latter bring forth once a year, one or two at a birth, which they nourish and bring up with the greatest care.

Inhabit all seas, especially the Polar, the Mediterranean, the Caspian, and it is said the Lake Baikal, the waters of which are fresh.

\section{Sub-Genus.}

\section{Phoca, Peron.}

Characters. No external ears; incisors simply cutting; molars cutting, and with many points; toes of the hind feet terminated by pointed nails placed on the borders of the membrane which unites them. 


\section{Species.}

1. Phoca cristata, Sea lion.

Phoca leonina, Fab.

Char. Essent. A sort of moveable hood attached to the top of the head, susceptible of erection and of being extended over the eyes and snout; four superior incisors, of which the lateral are largest; four inferior incisors.

Diniensions. Total length, seven or eight feet.

Description. Forehead of the adult male, carrying a sort of large tubercle, susceptible of swelling like a bladder, and carinated in its middle part; (besides the true nostrils, there exists false ones in the same tubercle, and the number of these false nostrils vary according to the age of the individual ;) thirty-two teeth in all, viz. four incisors above and below; one canine, and five molars on each side of both jaws; bristles of the whiskers large, nearly round, and whitish, annulated and compressed at base, obtuse at their extremities; iris brown; hairs soft and long, with a very deep woolly base.

Difference occasioned by age.-At one year, colour white, with the middle of the back livid gray; at two years, of a snow-white, with a narrow brown line on the back: the old ones having the head and feet black; the rest of the body equally black, but checkered with gray spots: the back remaining always obscure. 
Habit. This seal, according to Crantzius (hist. gen. des. voy. t. 19, p. 61.) is very abundant in the straits of Davis; making two voyages thence annually, and remaining there from the month of September to the month of March; it then seeks the shore to bring forth, and returns with its young in the month of June, very thin and emaciated. It departs a second time in $\mathrm{July}$, to go further north, where it probably meets with more abundant nourishment, for it returns in the month of September very fat. Fabricius assures us that they copulate standing.

Inhabit Greenland during the months of April, May and June; the Atlantic coast of North America.

An individual of this species was lately captured in Long Island Sound, fourteen miles from New York; for a particular and interesting description of which, including its anatomy, vid. annals of the New York Lyceum, vol. 1, p. 384, by J. E。 Dekay, M. D.

\section{Species.}

2. Phoca vitulina, Linn. (Encycl. pl. 109, fig。 4.) Phoque commun, Buff. tom. 13. pl. 45. Sab. Sea dog, Sea wolf, Sea calf of travellers and sailors.

F. Cuvier, obs. Zool. sur les faculties, intellect. du Phoque commun, Ann. du mus. t. 17, p. 337.

Char. Essent. Six superior incisors; four in- 
ferior; nails rather strong; bristles of the whiskers, undulating; colour of the animal, grayishyellow, more or less glazed with brown, according to age; hair abundant and thick.

Dinessions. Total length, from the extremity of the head to the end of the feet, three feet three inches six lines; of the head, six inches six lines; trunk of the tail, three inches four lines : circumference of the body, posterior, to the fore feet, one foot six inches.

Description. Body elongated, diminishing in thickness from the chest to the tail; neck very short; head round, having at its anterior portion much analogy to that of the otter; snout broad, flat, and truncated; upper lip very moveable, provided with whiskers; six incisors above, four below; four canine and five cutting lobate molars on each side of both jaws; ears marked only by a small tubercle at the anterior borders of their orifices; meatus auditorius opening anterior to the tympanum at the side of the eye; posterior portion of the head rery thick, without occipital or saggital crests; feet short, five-toed; the nails are largest on the hind feet, thick, long, free, and of a black colour; hair compact, not incumbent posteriorly as in other seals; general colour of the body of a grayish-yellow, more or less undulated with brown.

HaBiT. 'These animals are much more intelligent than could be expected from beings purely. 
aquatic; they become attached to man, and execute at his command various actions not very accordant with their natural habits. In captivity they feed on fish; remaining a considerable time under water without breathing, as they are enabled to close their nostrils accurately by means of a muscular apparatus, which has been described by M. de Blainville, (Bull. Soc. Philon.) Their voice is a sort of barking, rather weaker than that of a dog, which they utter during the evening or when the weather is about to change.

Inhabit the northern seas; frequent the coasts of Spitsbergen, Greenland, North America, Russia, Norway, Baltic, Holland, England and France.

Species.

3. Phoca groenlandica, Mull. prodr. p. 8. Phoca semilunaris, Bodd. Harp seal, Shaw, gen. Zool. tab. 71 .

Char. Essent. Six incisors above, four below; general colour of the adult male, whitish; forehead black; a large conical black spot on each flank; nails strong.

Dinersions. 'Total length, six feet; circumference, four feet.

Description. This species though confounded with the preceding, is nevertheless very distinct in size, number of molar teeth, and in colour, which resembles that of the Phoca oceanica, but it differs also from the last in the number of incisor teeth. 
Total number of teeth, thirty-two; viz. six incisors above, four below; two canine and twelve molars in each jaw on both sides; head long, depressed; snout very prominent; whiskers gray, slightly compressed and undulating in the middle, sharp towards the point; eyes, ears, tongue, and feet, like those of the common seal; hair very short, incumbent, brilliant.

Habrt. Feeding on fish, particularly the Salmo arcticus; copulate in the month of July; the females bring forth in the month of March, or beginning of April, generally one, rarely two at a birth, on the ice at a distance from land.

Inhabit the coasts of Greenland, from whence they depart in the month of March, and return in May; depart again in the month of July and refurn in September; they also visit Spitsbergen.

\section{Species.}

4. Phoca fetida, Mull. prodr. 8. Phoca hispida Schreb. tab. 86. Erxleb. Bodd. Gmel. Phoque neitsoak, Buff. hist. Nat. suppl. tom. 6.

Char. Essent. Six incisors above, four below; general colour a pale brown, varied with white above, dirty white beneath; hairs erect; nails strong.

Dimensions. (According to Fabricius, total length, upwards of four feet and a half.

Description. Dental system similar to that of the common seal; head short, rounded; length of 
the snout nearly equal to one third that of the head; whiskers pale, pointed, compressed; eyes small, with the iris brown; the feet, ears, tongue, and tail, are also similar to those of the common seal ; body nearly elliptical ; back very much arched; belly flat; hair thick, nearly straight, soft to the touch, long and fine; colour nearly brown, varied with whitish ; belly white, with some brown spots.

H $_{\text {ABiт. }}$ The old males emit a very stinking and nauseous odour, which taints their flesh and fat; the latter is very fluid; feeding principally on fish and crustacea : copulating in June, bringing forth in February.

Inlabits the least frequented coasts of Greenland.

\section{Species.}

5. Phoca barbata, Mull.

Phoca barbata, Oth. Fabr. Erxleb. Bodd. Gmel. P. major, Parsons, phil. trans. (Encycl. pl. 3. fig1.) Grand phoque, Buff.

Char. Essent. Six incisors above, four below; thumb of the hand shorter than the fingers; general colour blackish.

Dinensions. Total length about ten feet.

Description. Dental system like that of the common seal; head elongated; snout broad; openings of the ears larger than in other species; fore feet long, having the middle toe longest, the lateral smallest, (which is the case in no other 
species;) body elongated, robust; general colour livid above, white beneath, then blackish, or entirely black in old individuals.

Inhabits the high seas of Greenland.

\section{Species.}

6. Otaria ursina, sea bear.

Ursus marinus, Steller.

Phoca ursina, Linn. Gmel. Erxleb. Bodd.

Ours marin, Buff.

Chat marin, Krachenninikow, hist. du Kamtschat. (Encycl. pl. 109, fig. 1.)

Char. Essent. Six incisors above, of which the two lateral resemble canine; colour brown: posterior toes terminated by a large, narrow, cuticular nembrane.

Dunensions. 'Total length, six feet ten inches six lines; tail, one inch ten lines; ears, one inch six lines.

Description. Body thin posteriorly; head round; mouth small, six incisors above, four below; two canine above and below, very pointed; six sharp molars above, five below; ears pointed, conical; anterior feet entirely free, excepting the carpus, metacarpus, and fingers, where the skin is naked, wrinkled above, and smooth below ; thumb longer than the fingers, which decrease successively; posterior extremities five-toed, of which the thumb is as long as the three following; hair thick, crect; colour blackish. spotted with gray 
on the body, and yellowish or reddish on the feet and flanks ; beneath the hair a species of blackish fur; females differing in size and colour.

Habit. Very similar to that of the Otaria jubata, living in troops; the old males live separate, or dispute the females; gestation endures eleven months.

Inhabit the seas of Kamtschatka, the southern part of America, according to Forster, and North America, according to some authors.*

\section{Genus.}

Trichechus, Linn. Schreb. Cuv. Lacep.

Odobenus, Briss.

Rosmarus, Scopoli.

Manati, Bodd.

Morse.

chamactens.

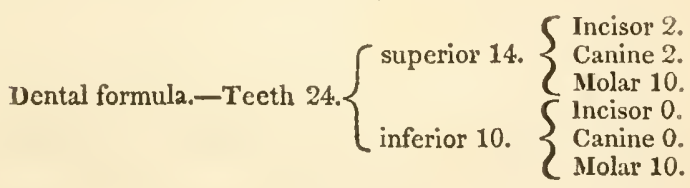

Two small incisors above in the young animal only and of the form of molars; two superior ca-

* Otaria is a subgenus of Peron. Character. Small external ears; six incisors above, four middle, with double edges, the external simple and smaller; four inferior, forked; all the molars simply conical; nails flat and thin; hair less rare than in ordi: nary seals. 
nine or enormous tusks, longer than the head, oval, laterally compressed, arched inferiorly, obtuse at the extremity; the internal ivory granulous, excessively hard, and disposed in curved lines as in the ivory of elephants; superior molar's rather small, nearly cylindrical, with simple crowns truncated obliquely, the first three situated more internally than the others, the third being the largest and the fifth the smallest; at a certain period two of these teeth fall; the inferior molars of similar form and decreasing regularly from the first to the last; body elongated and conical like that of the seal; head round, snout swollen; no external ears ; tail very short; anterior feet or fins, like those of the seal, with five toes, armed with very sharp nails; posterior feet in the same direction with the body, horizontal, with five toes united by a membrane, the two external the longest.

Species.

Trichechus rosmarus, Linn. Gmel. Erxleb.

Odobenus, Briss.

Equus marinus, Rai, syn. quad. p. 191.

Manati trichechus, Bodd.

Le morse, Buff. t. 13. pl. 54. Vulgarly Sea cow, Sea horse, the Morse, Sc.

Char. Essent. Lips very much swollen, with strong whiskers; two long tusks directed down- 
wards; hair very rare upon the body, short and reddish.

Druensions. Total length, eleven feet; of the tail, four inches; of the fore feet, one foot seven inches; hind feet one foot one inch; of the tusk out of the mouth, eleven inches.

Note.-The Morse attains to eighteen feet in length, and from ten to twelve in circumference.

Description. Head of moderate size relative to the body, rounded, obtuse; maxillary bone and anterior part of the head very much swollen; tusks in some individuals two feet long, rather converging; eyes small, brilliant; orifices of the ears situated far back; body thickest at the breast, tapering to the tail, which is comparatively longer than in the seal; neck short; skin very thick, mucous blackish, with some scattered, short, stiff, reddish or brownish hairs, more obvious on the legs; posterior feet very broad; four ventral nammæ; penis of the male very long and thin.

Haвiт. Very similar to that of the seal, living in troops composed of a hundred individuals; females bringing forth in winter on the ice or land, one at a time, which at birth is as large as a pig a year old.

Inhabit the northern Atlantic, where they abound, and the Polar Regions of the Pacific ocean; at present but one species is known. These 
animals are hunted for their oil, their skin and tusks, the ivory of which is more homogeneous than that of the elephant, and does not tarnish by time.

\section{Family MARSUPIALIA.}

Char. Growth of the young premature; frequently a pouch formed by a fold of the skin in the female, enclosing the mammæ, and destined to receive the young foetusses at birth; in some instances lateral folds exist as rudiments of this pouch. 'The Marsupial bones are peculiar to both sexes.

Scrotum and testicles, situate anterior to the penis, the glans of which is usually bifurcated; uterus communicating with the vagina by two narrow canals; thumb of the hind foot sometimes wanting, at others very distinct, without nail and opposable to the other toes; dental system very different in the various genera; canines sometimes wanting in one or both jaws; incisors varying from two to six or ten in number, in most instances the number varies in each jaw.

First division.-Long canines and small incisors in both jaws; abdominal pouch in the female sometimes wanting.

\section{Genus.}

Didelphis, Linn. Erxl. Bodd. Cur. Geoff. Illig. 
CHARACTERS.

1)ental formula. -Teeth 48 or $50 .\left\{\begin{array}{l}\text { superior } 24 \text { or } 26 . \\ \text { inferior 24. }\end{array} \quad \begin{array}{l}\text { Incisor } 10 . \\ \text { Canine } 2 . \\ \text { Molar } 12 \text { or } 14 . \\ \text { Incisor } 8 . \\ \text { Canine 2. } \\ \text { Molar 14. }\end{array}\right.$

Superior incisors small; the two intermediate rather longer and separate from the others; the inferior very small, nearly equal, slightly compressed and obtuse; canines strong, compressed and rather disposed outwards ; the inferior smallest. Superior molars, the first three false, triangular, compressed, the anterior being much smaller and separated from the others; crowns of the posterior furnished with indentations and sharp points; the first three inferior molars false; the crowns of the remainder furmished with points.

Head long, conical; snout very pointed; mouth wide; eyes placed very high, oblique; ears large, thin, nearly naked, borders rounded; tongue ciliated on its borders and prickled over with small points; whiskers long and abundant; five separate toes to all the feet; thumb of the hind feet, (which are plantigrade,) strong, rather long, opposable and nailless; nails of the other toes crooked.

Tail rather long, round, scaly, and destitute of hair for the greatest part of its extent; hair which covers the body, rather compact, often of two kinds ; stomach simple and small ; cœcum moderate. 
H the martins, but inactive and nocturnal; hiding during the day in bushes, holes or branches of t1ees; feeding on birds, eggs, reptiles, insects and fruit. Bringing forth a great number of young, which at birth are yet in an embryotic state, with only rudiments of limbs and tail, becoming immediately attached to the teat of the mother by the mouth, which bleeds when forcibly separated; less than one fourth of an irch long (in the opossum,) at the period of birth, when until very lately no traces of placenta or umbilical cord had been discovered. M. E. Geoffroy de St. Hilaire, (Anuales des Sciences Nat. 1824,) has just announced the discovery of the vestiges of a placental organization, and of an umbilicus, ubserved in a very small fetus of the "Didelphis virginiana." These observations have served to enlighten a most mysterious subject, and in the generation of the opossum, brings us back to the more usual, if not the more regular course of nature; in common with other mammifera, these animals do in fact pass through the various stages of gestation, changing only their locality at different periods. Thus they exist as ovum in the ovaries, embryon in the uterus, and fetus in the pouch. This interesting subject is as yet by no means divested of obscurity.

Inhabit all America. 


\section{Species.}

1. Didelphis virginiana, Penn. Gmel. Manicon, Bonnaterre, Opossum, of the Americans, Sarrigue, des Illinois, Buff. Virginiun opossum, Shaw, v. 1. part 2. pl. 107, (Encycl. pl. 246. suppl. 7. fig. 1.) Woapink, of some of the Indian nations.

Char. Essent. Covering woolly, mixed with black and white, traversed with white bristles; ears black and white; head nearly white.

Dinensions. Total length, one foot two inches nine lines; of the tail, eleven inches; of the head, four inches; of the ears, one inch.

Description. Body rather thick; head very pointed; facial line straight; nostrils separated by a vertical groove; covering composed of a mixture of fur and wool, of a dirty white near the skin, brown at the extremity, and traversed by hairs longer and often white; general teint more deep upon the back; head white; around the eyes and base of the ears brown, the latter being whitish at their extremity; feet brown; belly white; tail hairy one fourth its length, the remainder scaly and whitish; thirteen mamma, twelve disposed in a circle around a central one.

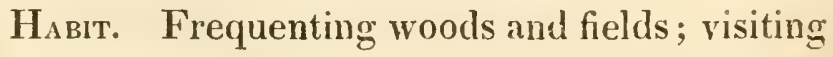
the farm yards at night, committing depredations on the poultry.

The young at birth weighing only one grain, and remaining in the maternal pouch until they have 
attained the size of a mouse, and are covered with hair; when they venture out, it is only for a short distance, re-entering at the first signs of danger; female producing from fourteen to sixteen at a birth; gestation continues for twenty-six days; the young remain in the pouch about fifty days after their birth, about which time their eyes open.

In captivity they are sluggish and by no means ferocious; they capture their prey by cunning and not by chase; their tail is prehensile, which enables them to suspend themselves on the limbs of trees, and thus fall upon and seize their prey; when discovered they seldom attempt to effect their escape, but on such occasions their cunning in simulating death in order to avoid destruction is proverbial; they are omnivorous and fond of persinmons and apples; the flesh of the female is eaten, and when roasted, is said to resemble a young pig in flavour; the male emits a strong odour; the urine fetid.

Inhabit the eastern coast of the American continent, from Paraguay to the Great Lakes; they abound in the middle states. 


\section{Order GLIRES, Gnawers.}

\section{Glires, Linn. Rosores, Storr.}

Char. 'Two large incisors in each jaw, separated from the molar's by a vacant space. No canine teeth; molars sometimes compound, with flat crowns; sometimes with blunt tubercles. Extremities terminated by a variable number of toes furnished with claws. Thumb sometimes rudimentary or wanting, never opposable to the fingers. Mammæ varying in number; orbits not separate from the temporal fossæ; zygomatic processes moderately arched, thin and curved inferiorly.

Inferior jaw articulated by a longitudinal condyle; posterior extremities generally longer than the anterior; stomach simple; intestines long; cœcum voluminous when it exists.

Nourishment, purely vegetable in those species which have compound molars with flat crowns; mixed with animal substances in those which have simple molars with tubercular crowns.

HabrT. Generally nocturnal and timid; triturating their food with their molars after having torn it with their long incisors, which have angular summits, and are produced from their roots as they are worn at the points.

Inhabit both the old and new continents: not found in the south-sea islands. 


\section{Section I.}

Gnawers with clavicles.

Char. Clavicles complete, often very strong.

\section{Genus.}

Castor, Linn. Briss. Schreb. Cuv. Geoff. Illig.

\section{CHARACTERS.}

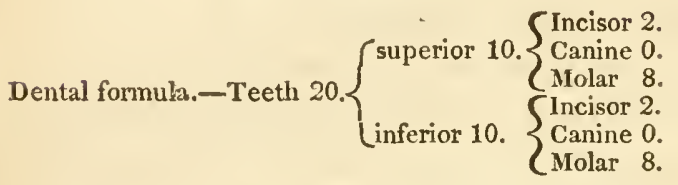

Incisors very strong; anterior faces, even and flat; posterior faces angular; molars compound, their crowns nearly plane, presenting circumvolutions of enamel and grooves on their sides, viz. three external and one internal on the molars of the upper jaw; one external and three internal on those of the lower jaw ; eyes small; ears short and round; five toes to each foot, the anterior short and not separate; the posterior longer and united by a membrane; tail broad, depressed, oval, naked, and scaly. Two pouches containing an unctious and odoriferous matter, situate on each side of the male organs of generation. The salivary glands very large.

\section{Species.}

1. Castor fiber, Linn. Erxleb. Schreb. tab. 175. 
Le castor, ou Le bièvre, Briss. regn. anim. p. 133. Le castor, Buff. hist. nat. t. 8. pl. 36. F. Cuvier, Mamm. Lithogr. (Encycl. pl. 79. fig. 1. and 2.) Sabine, append. p. 659. Long's exped. vol. 1. p. 46. Common beaver.

Char. Essent. Fur consisting of two sorts of hair; one coarse and brownish; the other a very fine down, more or less gray.

Dinensions. Total length, two feet six lines; of the head, five inches; of the tail, one foot; breadth of the tail, four inches; height before, ten inches four lines; behind, eleven inches; length of the fore arm, four inches; from the wrist to the end of the nails, two inches four lines. Some individuals attain to three feet in length.

Description. Snout short and thick, furnished with strong whiskers; facial line rather arched; summit of the head flattened; eyes rather small, of a blackish colour; ears short and rounded; neck short; body rather thick and short, particularly at its posterior part.

Back arched; tail very flat, broad, oval, and naked, the skin of which is covered with scales, generally of an hexagonal form, thicker beneath than above. The fine soft hair is of a silver-gray colour, offering some differences of shades; the coarser hair, long, stiff, and elastic; gray for the first two-thirds of its length, and terminated by a 
reddish-brown, from whence results the general colour, which is more brilliant above than beneath; whiskers black; hair of the head and hands or feet, shorter than that on other parts.

'The varieties of this species resolve then!selves into the white, black, olive, variegated, and yellow.*

Some doubts have been expressed relative to ${ }^{\circ}$ the identity of the American and European beaver, founded chiefly on some difference observed in their habits. (The European beaver does not construct huts.) We are inclined to the opinion of their identity, the more especially as no differences are observable on comparing their skulls.

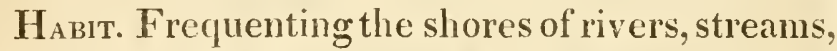
or lakes; in the summer remaining solitary in their holes; in winter uniting in troops, in a species of hut, which they construct with the greatest ingenuity in the banks; intercepting the current to form dams, which they effect by the aid of dikes, in form of an arch, the convexity of which is opposed to the current, and which is composed of stones, mud, and the branches of trees interlaced.

The huts are established on these dams, and formed of nearly the same materials as the dikes:

* The late Mr. Bartram has indicated two species of beaver as inhabiting the United States, viz. "Great beaver of Canada," and "Lesser beaver of Florida and Carolina." Manuscrips notes, penes me. 
the huts are two stories high, each story eighteen inches in height; logs composing these cells have been observed measuring two feet in length, sixteen inches in circumference, and weighing fourteen pounds; it is evident from the marks on the ends of these logs, that they have been all cut through with the teeth, and notched at the end, so as to interlock with each other in the same manner as logs fashioned by human industry for the purpose of constructing the common $\log$ houses. The base of the lower chamber is under water, as is also the hole by which they enter.

'They feed on the bark of the willow, poplar, and cotton wood tree; they swim well, in which action they are aided by their posterior palmated feet, and flat tail. The female brings forth at the commencement of spring, two or three at a birth, after a gestation of four months. They arrive at maturity in two years; the duration of their life is about fifteen years. Such are, nearly, the manners of the North American beaver; those which exist in Europe do not build, but dig holes in the earth on the borders of rivers.

The fur of these animals is exceedingly valuable; but from the constant and universal destruction to which they are subjected, we must, before long, be deprived of this luxury.

For further very interesting particulars concerning the habits of this extraordinary animal, vid. Long's Exped. to the Rocky Mountains. 
Inhabit North America, from Canada to the thirtieth degree of north latitude; on either side of the Rocky Mountains. Siberia, and northern and temperate Europe.

\section{Genus.}

Osteopera, Nobis.

$$
\begin{aligned}
& \text { Characters. }
\end{aligned}
$$

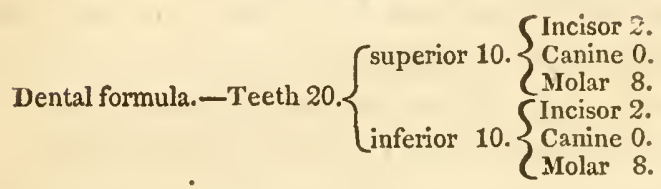

Inferior incisors slender, laterally compressed, nearly pointed, not approximate, convex anteriorly; molars nearly similar to those of the beaver; head very broad and flat; snout rapidly attenuated; eyes widely separated; zygomatic arches exceedingly large, descending beneath the inferior molars, scabrous and convex externally, forming within large osseous pouches communicating with the mouth, anterior to the molars; lower jaw proportionably small and slender; the condyloid extending above the coronoid process.

\section{Species.}

\section{Osteopera platycephala.}

Char. Essent. Head flat, ventricose at the sides; snout obtuse; eyes widely separated.

Dimensions of the cranium compared with that 
of the full grown Canadian beaver: (the extremity of the snout of the Osteopera, together with the upper incisors, have been destroyed.)

\begin{tabular}{|c|c|c|c|c|c|c|}
\hline & & & W G & ienu & isto & fiber \\
\hline Total length of the skull, - & - & Inches & 6 & 0 & 5 & 0 \\
\hline Length of the frontal bone, & - & - & 2 & 5 & 1 & 5 \\
\hline Breadth of & - & - & 1 & 8 & 1 & 0 \\
\hline Length of the parietal bone, & - & - & 3 & 0 & 1 & 7 \\
\hline Breadth of & - & - & 2 & 3 & 1 & 6 \\
\hline Length of the zygomatic arch, & - & - & 3 & 6 & 3 & 0 \\
\hline Breadth of & - & - & 2 & 0 & 1 & 2 \\
\hline Width across from one zygom & a to the othe & & 4 & 0 & 4 & 0 \\
\hline Breadth of the palate bones be & etween the $\mathrm{m}$ & nolars, & 0 & 4 & 0 & 8 \\
\hline Length of the zygomatic fossa, & - & - & 1 & 7 & 2 & 3 \\
\hline Breadth of & - & - & 1 & 2 & 1 & 0 \\
\hline Length of the lower jaw not in & cluding the & incisors, & 4 & 0 & 4 & 0 \\
\hline $\begin{array}{l}\text { Breadth of the same including } \\
\text { From the top of the coronoid }\end{array}$ & $\begin{array}{l}\text { the molars, } \\
\text { process to th }\end{array}$ & base & 1 & 3 & 1 & 5 \\
\hline of the jaw, & - & & 1 & 2 & 2 & 4 \\
\hline
\end{tabular}

Description. Frontal bone nearly double the length and breadth of that of the common beaver, flat and scabrous, forming on each side a similunar ridge, projecting into the orbits; orbit of the eye small, and nearly circular, which is due, principally, to the extraordinary development of the zygomatic processes of the temporal and jugal bones, which are produced downward and backward, so as to conceal the posterior half of the lower jaw, together with the teeth, anteriorly arched, scabrous, and ventricose; the jugal portions being developed anteriorly and inferiorly so as to form on each side a bony antrum, or cavity, rapable of containing in all two or three ounces 
of fluid, and communicating with the mouth by large oblong openings, immediately anterior to the molar teeth; the cavity projecting posteriorly into the orbit, with which it has no communication; anterior to the orbit, above the cavity, is a bony canal, capable of admitting the little finger, somewhat analogous to the infraorbitar foramen observed in the skull of the genus Cavia.

The structure of the inferior jaw is equally remarkable, and adapted in every respect to the peculiarities of the upper jaw; the whole of the lower jaw is more slender and narrower than that of the beaver. In order to admit a free passage from the bony cavities into the mouth, the molar teeth and alveolar processes of the lower jaw are elevated, and the latter are separated from each other anteriorly, so as to leave a capacious opening, of an oval form, from the sack into the mouth ; the coronoid process very small, and not projecting so high as the condyloid; the latter also small, rounded above and compressed; angles of the lower jaw rounded; the inferior incisors slender in proportion to those of the beaver, arched on the anterior surface, not approximate, slightly divergent at their extremity, somewhat analogous to the incisors of the squirrel; the crowns of the molars are plain, though they do not appear to have been much worn, and are traversed by three, sometimes four folds of enanel, which, in several of the teeth, have no connexion with the enamel 
which encircles them; in others they consist of re-entering folds, as in the teeth of the beaver; thus displaying, in a remarkable manner, the extent to which this portion of the structure of the - teeth may differ in the same individual: in those instances where the transverse plates of enamel are distinct from the encircling enamel, there are no grooves on the side of the tooth; in other instances, the sides are grooved, as in the teeth of the beaver, except that portion buried in the socket, which is smooth in most instances. In all other details, this skull bears the closest analogy to that of the beaver. 'The animal was full grown, as is evinced by the teeth and other particulars.

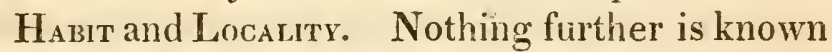
concerning the history of this animal, than that its skull was found more than thirty years ago on the shore of the river Delaware, and presented to the Philadelphia Museum; when first discovered it was nearly perfect; by rough usage it has since lost the upper incisors, and part of their alveoles. This cranium has been frequently examined by the curious, and by them regarded as a lusus nature; the characters which it presents are certainly unique of their kind; the bony cavities communicating with the mouth, which must have served as receptacles for provision, \&c. distinguish this skull from that of all other animals, and particularly the beavers, to which, in other respects, it bears so near a resemblance. That it is not a 
monstrous production of nature, is fully demonstrated by the well defined characters of the jaws and teeth, as well as by the harmonious adaptation of its various parts. It is further, not in the least degree fossilized, nor does it appear to have been totally buried in the ground, inasmuch as one side of the jaw has been bleached by exposure to the sun.

The first question which presents itself for solution is, from whence came the animal? are we to consider it as the type of a genus which has become extinct and yet not fossil? or does it owe its present locality to accident, having been brought from some distant and unexplored country, and heretofore escaped the eye of the naturalist?

The present existing genera to which it is most nearly allied, being known to inhabit only Europe and America, would militate against the latter opinion, and induce us to believe, that this animal did inhabit the countries near which its remains were first discovered, its residence like that of the beaver, being on the banks of livers.

The skull being recent, and not in the least decomposed, the animal could not have been long dead when first discovered. It is most probable that in the instance before us, we are presented with the remains of the type of a genus which has become extinct since the settlement of North America, or if it still exists has reireated to the 
most inaccessible and unexplored forests, which is at least very uncertain. It is more than probable that many species have disappeared and are entirely lost since the present state of the surface of our globe.

Suppose an animal to inhabit the shores of the great rivers of America previous to the discovery of this continent, and not to be endowed with the instinct of emigration, to become surrounded by the habitations of civilized man; hemmed in, and cut off from all resources by the march of civilization, the natural consequences would be destruction.

It may be necessary further to remark, that all the fossil beavers hitherto discovered, resemble the recent species.

\section{Genus.}

Fiber, Cuv. Geoff. Illig.

Ondatra, Lacep. Geoff.

Castor, Briss. Linn. Erxleb. Bodd.

Mus, Gmel.

CHARACTERS.

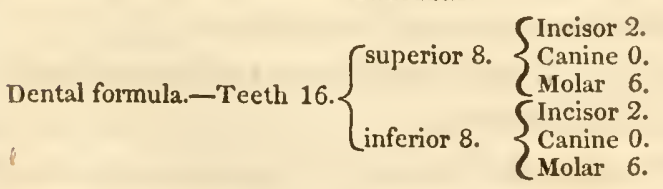

Superior incisors plane and chissel form; inferior sharp, and rounded anteriorly; molars compound, presenting transverse zigzag plates. 
Anterior feet, four-toed; the thumb rudimentary; the posterior, five-toed; all very distinct, with their borders furnished with stiff hairs, which serve in place of the membranous feet of aquatic mammifera.

Tail long, linear, laterally compressed, the skin of which is naked and granular, with a few scattering hairs; glands near the pubis, secreting a whitish odoriferous matter, which is discharged by two ducts, either at the base of the glans of the male, or in the ureter of the female.

Six ventral mammæ.

\section{Species.}

1. Fiber zibethicus, Desm. Mamm. p. 279. Sab. Append. p. 659.

Rat musque, Sarrazin, Mem. de l'Acad. Roy. des Scien. de Paris, 1725. Rat musquè du Canada, Briss. regn. Anim. Castor zibithecus, Linn. Erxleb. Bodd. Ondatra, Buff. (Encycl. pl. 67, fig. 7.) Ondatra of Canada. Mus zibethecus, Gmel. vulgarly, Musk-rat.

Char. Essent. General colour brown, tinged with red above; cinereus beneath.

Dimensions. Total length, one foot seven lines; of the tail, nine inches.

Description. In external appearances very analogous to the water-rat, but differing in the compressed form of the tail; snout short and thick; eyes large and lateral; ears short, oblique, round- 
ed, and entirely covered with hair; whiskers very large; fur soft and shining, composed of two sorts of hair, the longest reddish-brown on the superior parts of the body; cinereus-red on the flanks, breast, and belly; down or interior hair of the back very fine and soft, of a cinereus colour near its roots, and reddish-brown at its points; that of the inferior parts of a clear gray, and brilliant; feet covered with short and shining hair; tail threefourths the length of the body, compressed, covered with small scales of a blackish-brown colour; between these are small black hairs, which are longest on its borders.

Hавіт. Living in small families on the borders of waters; swimming with facility; feeding on roots, fruits, \&c. copulating in spring, at which period in particular, they shed a strong odour of musk; female bringing forth five or six young annually.

Inhabit Canada, and the northern and middle states.

According to Bartram, the "Musk-rat is never seen in Carolina, Georgia, or Florida, within one hundred miles of the sea coast, and very few in the most northern parts of these regions; which must be considered a most favourable circumstance in a country where there is so much banking, and draining of the land, they being the most destructive creatures to banks." - Vid. "Travels in North America." 


\section{Genus.}

Arvicola, Lacep. Cuv. Desm.

Lemmus, Geoff.

Hypudœus, Illig.

Mus, Briss. Linn. Erxleb. Bodd.

\section{CHARAETERS.}

Dental formula.-Teeth 16. $\begin{cases}\text { superior 8. } & \left\{\begin{array}{l}\text { Incisor 2. } \\ \text { Canine 0. } \\ \text { Molar 6. } \\ \text { inferior 8. }\end{array}\right. \\ \left\{\begin{array}{l}\text { Incisor 2. } \\ \text { Canine 0. } \\ \text { Molar 6. }\end{array}\right.\end{cases}$

Incisors of the upper jaw large, cuneiform; the inferior sharp.

Molars compound; crowns marked with zigzag lines of enamel; the largest situated anteriorly, the smallest posteriorly.

Fore feet having the rudiment of a thumb, and four toes furnished with weak nails; the posterior with five toes, armed with claws, not palmated or furnished with hairs on their borders:

Tail hairy, cylindrical, nearly as long as the body. From eight to twelve pectoral and ventral mammæ.

HaBit. Burrowing in the earth, feeding principally on grain and bulbous roots; some are omnivorous.

Inhabit both the old and new continent.

Species.

1. Arvicola amphibius. 
Mus amphibius, Linn. Erxleb. Bodd. Schreb. Mus aquaticus, Briss. Rat d'eau, Buff. (Encycl. pl. 68. fig. 9.) Water-Rat.

Char. Essent. Colour blackish-gray, slightly mixed with yellow, more clear beneath; tail longer than one-half the body, black; ears short, hairy.

Dimensions. Total length seven inches; of the head, one inch seven lines; of the ears, five lines and a half; of the trunk of the tail, four inches six lines.

Description. Head short; suout swollen; ears slightly apparent, hairy ; tail rather more than onelialf the length of the body, furnished with short and sparse hairs ; colour of the fur blackish-gray above, more clear beneath, composed of hairs, the points of which are yellowish, but the greater part of the base clear cinereus-yellow; some larger hairs of a blackish-brown colour, longer than the rest, and placed on the top of the neck; down or fine hair covering the skin, generally of a grayish colour.

Varieties. Mhus amphibius niger, Limn.

Mus amphibius maculatus, Linn.

Mus amphibius paludosus, Linn.

Habit. Living in holes on the sides of banks of rivers, dams, \&c.; they swim well, but are obliged to come to the surface of the water to breathe every half minute: feeding on water-plants and herbs; also insects, spawn, and frogs, \&c. The 
female brings forth in the month of April, five or six at a birth.

Inhabit all Europe, Asia, and North America. From Canada to Carolina according to Penn. Arct. Zool. Carolina, according to Lawson.

\section{Species.}

2. Arvicola xanthognatha. Meadow Mouse, Leach, Miscellanea, vol. i. pl. 26. p. 60.

Arvicola xanthognatus, Sabine, append. p. 660.

Char. Essent. Fawn coloured, varied with black above, clear cinereus-gray beneath; cheeks yellowish.

Dimensions. Total length five inches.

Description. Tail black above, and white beneath; feet brownish, white beneath. 'This species has some resemblance to the Arvicola vulgaris, (Mus terrestris, Linn.)

Inhabits the borders of Hudson's Bay, state of Ohio, Pennsylvania, \&c.

The exploring party under Major Long observed this animal on the Ohio. Vid. Exp. to the Rocky Mountains, vol. i. p. 369.

\section{Species.}

3. Arvicola palustris, (nobis.)

Marsh campagnol.

Arvicola riparius, Ord, Journal of the Phil. Acad. of Nat. Sciences, vol. iv. 
Char. Essent. Body above dark grayishbrown; pale plumbeous beneath; snout rather elongated, reddish-brown at its extremity; ears moderately long, sparsely bordered with hair.

Tail short, sparsely hairy.

Dimensions. Total length, from the tip of the nose to the base of the tail, very nearly six inches; length of the tail two inches and three-tenths.

Description. Body elongated, thickest behind, covered above with soft fur, plumbeous at base, and tipped with gray and brown, from whence results the general colour, dark grayish-brown above, lighter on the flanks and sides, becoming reddish-brown on the end of the snout, and beneath the tail, between the hind legs; belly, inside of the legs, and throat, of a pale plumbeous colour, occasioned by the hairs being plumbeous at base, and white at the extremity; head long and narrow; snout rather elongated; facial line straight; ears situate far back, moderately long, internal border lined with sparse hair, posterior surface nearly naked; whiskers fine long hairs, white and black; inferior incisors very long, distinct, gently recurved at top, laterally compressed, very sharp and pointed, yellow on the anterior surface, and convex; upper incisors much shorter and cuneiform.

Molar teeth unusually long at the crowns, and so deeply groored laterally, that when viewed in this direction, these animals appear to possess six 
or eight, in place of three molars on each side, the usual number; eyes large, situate six-tenths of an inch from the extremity of the snout.

Legs small, terminated by five clawed toes behind, four before. The fore feet brown above; middle toe the longest, then the next on each side, the outer one small, all furnished with hooked nails; the thumb tubercle very small, and furnished with a scarcely visible nail.

The three middle toes on the hind feet nearly equal; the two remaining toes very small, particularly the interior; all furnished with nails similar to those on the fore toes.

Tail small and short, sparsely covered with brownish hair.

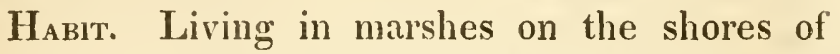
rivers; they dive well, and swim with facility; their habits in many respects resemble those of the Arvicola amphibius; they bring forth six or eight young at a birsh; feeding principally on the wild rice, (Zizania aquatica.)

Inhabit the swamps along the shores of the Delaware. (Specimens in the Philadelphia Museum.)

\section{Species.}

4. Arvicola hortensis, (nobis.)

Char. Essent. Body ferruginous-brown above; plumbeous, intermixed with yellow beneath; hairs coarse, standing more or less obliquely from the 
body, giving the animal a shaggy appearance; ears broad, oval ; head globular; snout contracted, conical; tail more than one-half the total length.

Dimensions. Total length, from the tip of the nose to the origin of the tail, five inches and fivetenths; length of the tail two-inches and seventenths.

Description. Body covered with rather long, coarse hair, of a dark plumbeous colour for the greater portion of its length next the skin, but reddish or dusky brown, sometimes grayish at the extremity, standing more or less obliquely from the body, which occasions the plumbeous colour of the inferior portion to show through in some places, giving the animal a motley, shaggy appearance; beneath the throat of a dirty yellowish-white; belly ochreous-yellow, intermixed with plumbeous; tail rather thickly invested with blackish-brown hair, lighter beneath; head rather broad; snout contracted, conical; facial line arched; ears six-tenths of an inch broad, the same in height, hairy within, sparsely hairy without; coarse, stiff hairs lining the anterior borders; whiskers, numerous, fine, long hairs, both black and white.

Molar teeth rather oblong, deeply grooved at their crowns, and marked by several transverse curved lines of enamel; the grooves extending nearly one-half the length of the sides of the bodies; the lower incisors rather shorter, the upper rather longer than in the preceding species. 
Feet small, brown above; the number of toes and nails, their form and situation, do not materially differ from the same parts in the preceding species.

Haвiт. Mr. Ord discovered these animals in Florida in the year 1817 or 1818 , and presented specimens to the Philadelphia Museum, where they have remained ever since, undescribed. He states that they frequent the ruined gardens of deserted plantations; feed on seeds, grain, \&c.; they are very abundant also on the borders of marshes, and constitute the principal food of the Marsh-Hawk, as we are informed by Mr. T. Peale.

Note.-The molar teeth of this species present some differences from those of the common Arvico$l a$, and resemble somewhat those of the genus Lemmus; but the following, among other characters of this latter genus, "ears very short," and "tail very short," \&c. will not apply to the present species; in all other respects it resembles the Arvicola much more closely than any other genus; it must consequently be referred to the former, or establish a new genus; the latter alternative would be as unwarrantable as to make distinct genera of the two existing species of Elephants.*

* Some weeks after the above description had been drawn up, and read before the Philadelplia Academy of Natural Sciences, Messers. Say and Ord thought it necessary to describe the same animal, and to construct from it a new genus, which they name "Sigmodon." For this distinction they have no other founda- 


\section{Species.}

\section{Arvicola floridanus.}

\section{Mus floridanus, Ord, Nouv. bull. de la Soc. Phi-}

tion than a slight and unimportant variation in the form and direction of the plates of enamel, which traverse the crowns of the molars, and the partial division of the root into rudimentary radicles. On similar distinctions, F. Cuvier has founded his divisions of the genus Arvicola, which "differ from each other in the number of parts of which the teeth are composed."

It could be shown, if necessary, in a number of instances, that greater differences are observable in the different teeth of the same individual, than have served those gentlemen, in the present instance, to construct a new genus; who, in their description of the animal, have entirely neglected to point out any generic distinctions in the external characters, (which, in reality, correspond with the genus Arvicola.) This neglect is the more extraordinary, as in their former descriptions they have divelt upon the external characters of animals, and, in some cases, to the exclusion of any observations on the structure of the teeth, as was instanced in the "Mus floridamus." The slight variations in the teeth noticed above, provided they be accompanied with well marked differences in the external characters of the animal, may form good grounds for specific distinctions, but surely cannot be received as sufficient reason for the construction of a new genus, according to the established laws which regulate naturalists in similar instances; particularly as nature acknowledges no such distinction, inasmuch as the food, the manners, the habits, and we may add, the external characters of this animal, correspond with those of other species of the genus Arvicola.

We have divelt the longer on the principles involved in this dispute, believing that, if the precedent be established, it might prove fatal to the best interests of science.

Note.-The description of the present species is drawn from ne of the three individuals presented to the Museum by Mr. Ord. 
lomat. Decem. 1818. Mus floridanus, Say, Long's Exped. to the Rocky Mountains, vol. 1. p. 54.

Char. Essent. Body robust, black plumbeous; sides, rump, and origin of the tail, ferruginousyellow; fur plumbeous near its base; all beneath white.

Dinersions. Total length including the tail, nearly sixteen inches; tail, seven inches; ear, ninetenths; greatest breadth, one inch.

Description. Head gradually attenuated to the nose, plumbeous, intermixed with gray; ears large, prominent, patulous, obtusely rounded, naked or furnished with sparse hairs behind, and on the margin within; eyes moderate, prominent; whiskers, some white, some black bristles, the longest surpassing the tip of the ears, arranged in six longitudinal series; tail hairy, as long as the body, above brown; legs subequal, robust; feet white; toes annulate beneath; thumb minute; palm with five tuberculous prominences; nails concealed by the hairs; sole with six tubercles; the three posterior ones distant from each other. (Say.)

Habit. Feeding on vegetables, such as the green bark of trees, and the young shoots of plants; their nests are large, and composed of a great quantity of brush. This species is well known in some districts under the name of large hairy tailed rat, and is by no means rare in Flori- 
$\mathrm{da}$; it is as large as the ordinary stature of the Norway rat, and equally troublesome; infesting houses, but gives place to the Norway rat.

Inhabit Florida and the borders of Mississippi river. Two prepared specimens in Philadelphia Museum; one from Florida, presented by Mr. Ord, the other from Mississippi, presented by Maj. Long's exploring party.

A beautiful figure accompanies Mr. Ord's description of this animal, in vol. 4 of the Journal of the Philadelphia Academy of Natural Sciences.*

* Since this work went to press, we hare received No. 11 of the Journal of the Academy of Natural Sciences, in time to follow up the eventful history of this animal. In vol. 4, p. 345, of the work above quoted, there is an essay entitled "A New Genus of Mammalia, \&c. proposed by T. Say, and G. Ord; read March 8, 1825." The name of the proposed genus is " $\mathcal{N e o -}$ toma." There appears to have been some mistake relative to the date, wherein it is stated that the new genus "Neotoma" was proposed; at any rate, it is very certain that on the evening of the 8th of March, the identical animal on which this new genus is founded, was described by those gentlemen as an " $A \%$ vicola," and this after an attentive examination of the teeth. It was not until this description of the "Arvicola floridanus" had passed through the press, that it was recalled by the authors, and the new name substituted. In order to avoid confusion, it will be necessary for naturalists to remember that the animal under notice, is at present described as pertaining to three or four distinct genera. The first notice of this animal, is an imperfect description by Mr. Ord, in the Bull. de la Soc. Philom. 1818, who named it ".Nus floridanus," (its identity with the genus .My. was doubted from the first, by the French natural- 


\section{Species.}

\section{Arvicola Pennsylvanica.*}

ists.) A more complete description occurs in Maj. Long's exped. to the Rocky Mountains, vol. 1, p. 54.1819-20, where Mr. Say has adopted in an unqualified manner the name given by Mr. Ord. Thus it remained until the attention of these gentlemen was particularly directed to the dentition of this animal, by the observations of M. Desmarest, in his "Mammalogie." They now described the animal as an Arvicola, (to which, in reality, it belongs.) Finally, observing that the molar teeth of the animal were furnished with "roots," they have constructed the new genus "Neotoma." (The division is sufficiently novel, it must be confessed, and if adopted, would destroy the whole fabric of classification.)

F. Cuvier has not mentioned the roots of the molar teeth of those species from which he has drawn the characters of the genus Arvicola; a circumstance so apt to vary even in the teeth of the same animal, this able naturalist considered as beneath his notice in a work which has for its object a description of the teeth considered as zoological characters. ("Dents des mammifères considerèes comme charactèrès zoologiques.") Notwithstanding this, Messrs. Say and Ord, consider the "roots" of the teeth as of sufficient importance to establish generic listinctions. In the present instance, at least, they admit, that in the softness of the fur, and in the tail being clothed with hair, the "Neotoma" resembles the Arvicola; to which I would add, that in all other external characters, this species resembles the $A_{r}$ vicola, as closely as the different species of that genus resemble each other.

The description which Messrs. Say and Ord have given of the tceth of the "Neotoma," (always excepting the roots, so exactly corresponds with M. Cuvier's description of the teeth of the genus Arvicola, that we are tempted to believe the former to be a literal translation. (Vid. Dents des mammifires, (Sc. F. Cuvier: first division, page 155.) 
The Campagnol or Meadow Mouse of Pennsylvania. Warden's Descrip. of the United States, vol. v. p. 625 .

Described in Wilson's Ornithology, vol. vi. pl. 50. fig. 3. Arvicola Pennsylvanica, Ord. Guthrie's Geography.

Description. Colour above a brownish-fawn; beneath grayish-white; eyes very small; ears short and round.

Dimensions. Total length, from the origin of the tail to the extremity of the nose, four inches; tail three-fourths of an inch.

Habit. Feeding on bulbous roots; injurious to river plantations, making holes in the banks. According to Mr. Ord, the female brings forth only two young at a birth; the teats of the female are situated very near the organs of generation; she carries her young between the hind legs.

Probably a variety of the Arvicola xanthognathus, described p. 136.

\section{Genus.}

Lemmus, Link, Cuv. Geoff.

Hypudaus, Illig.

Georychus, idem.

Mus, Linn. Pallas. Gmel. Bodd.

Glis, Erxleb.

Lemming.

EHARACTERS.

Dental formula. - Teeth $16 .\left\{\begin{array}{l}\text { superior } 8 . \\ \text { inferior } 8 .\end{array} \begin{array}{l}\text { Incisor } 2 . \\ \text { Molar } 6 . \\ \text { Incisor } 2 . \\ \text { Molar } 6\end{array}\right.$ 
The anterior face of the superior incisors convex and smooth; the inferior sharp; molars compound, with plane crowns, presenting angular plates of enamel; ears very short and rounded; eyes very small; anterior feet sometimes five-toed, sometimes four-toed, with claws proper for digging; posterior feet five-toed; tail very short and hairy; (this genus differs from the preceding chiefly in the disproportion of the fore legs, and shortness of the tail.)

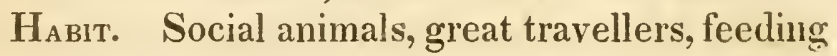
chiefly on vegetable food.

\section{Species.}

1. Lemmus hudsonius, Sab. append. p. 669.

Mus hudsonius, Pallas. Schreb. Gmel. (Encycl. pl. 69. fig. 6.) Lemming of Hudson's Bay.

* Char. Essent. Of a clear cinereus colour; four fingers, and a rudiment of a thumb on the fore feet; the two internal nails (in the male) appear very large and double; no apparent external ears.

Dinersions. 'Total length about five inches.

Description. Body short and swollen; head large ; eyes very small ; feet short; fur soft, generally of a cinereus-gray colour, which is owing to the points of the hairs, the bases of which are brownish.

Inhabit Labrador and northern parts of North America.

Noтє.-The following species are noticed by 
Rafinesque, which we mention as mere indications of varieties, or perhaps some new species. 1. Lemmus vitiatus; inhabits Kentucky. 2. L. talpoides, also of Kentucky. 3. L. noveboracensis, together with the Mynomes pratensis, figured by Wilson, Amer. Ornithol. vol. vi. tab. 50. fig. 3. which is an .Arvicola.

\section{Genus.}

Mus, Linn. Erxleb. Briss. Cuv. Geoff. Illig. \&c. Rattus, Pem. the Rat.

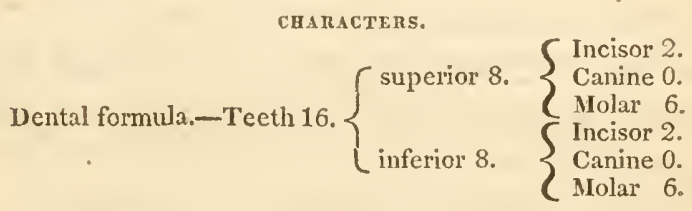

Superior incisors cuneiform; the inferior compressed and sharp.

Molars simple, crowns furnished with blunt tubercles, the anterior being the largest both above and below; snout rather elongated; ears oblong or rounded, nearly naked; no pouches.

Anterior feet with four clawed toes, and a wart covered with an obtuse nail in place of a thumb; the posterior feet moderately elongated, with five clawed toes; tail long, tapering, naked and scaly. Some of the hairs on the body are longer, and more stiff than others; for which are sometimes substituted flattened spines, similar to those on the body of the echimys. 
Habit. Omnivorous, lascivious, and nocturnal. Inhabit all climates and countries of the earth: some species have become cosmopolites.

\section{Species.}

1. Mus rallus, Linn.

Mus domesticus major, Rai. Le rat, Buff.

Rattus niger, Penn. Syn. Quad. p. 299. The Black rat.

Char. Essent. Black above, deep cinereus beneath; tail a little longer than the body.

Dinensions. Total length seven inches; of the head one inch nine lines; of the tail seven inches six lines.

Description. Head elongated; snout pointed; inferior jaw very short, and much less projecting than the superior; eyes large and projecting; ears naked, large, broad, and nearly oval; whiskers long; five flat toes on the hind feet, and four on the anterior, with a nail representing a thumb; lateral nails, both before and behind, very short; tail nearly naked, and furnished with scales disposed in rings, the number of which amount in some instances to two hundred and fifty; ordinary colour of the animal, cinereus black, lighter beneath; whiskers black; small white hairs covering the top of the feet; mammæ to the number of twelve.

Habit. Bold, courageous, and great depreda- 
tors, their manners resemble those of the common rat.

Inhabit France, Germany, England, \&c.

We are inclined to believe this species indigenous to the United States, where they were very numerous about fifty years ago, though they have become very rare on the Atlantic coast since the arrival of the Norway rat, (Mus decumanus, Pall.) and are found at the present time, (though rarely) in the western states, having like the aboriginal Indians, receded before their European invaders. We are credibly informed by an eye witness of the fact, that the Norvegian rat did not make its appearance in the United States any length of time previous to the year 1775 .

The Norway rat, it appears, was originally a native of Persia, or of India, and was unknown in England previous to 1730 , or in France before 1750. According to Pallas, it made its first appearance in Siberia and Russia about the year 1766.

The Mus musculus, (Linn.) Common mouse, is most probably not indigenous, though like the preceding species, it inhabits all clinates.

\section{Species.}

2. Mus sylvaticus, Linn. Erxleb. Bodd. Schreb. tab. 180. Mus agrestis major, Gesn. Mus domesticus medius, Rai. Mus campestris major, Briss. Regn. Anim. p. 171. No. 4. Mulot, Buff. hist. nat. t. 7. pl. 41. Field mouse. 
Char. Essent. Reddish-gray above; whitish beneath; tail a little shorter than the body.

Dimensions. Total length, four inches two lines; of the head, one inch two lines; of the trunk of the tail, three inches six lines.

Description. Larger than the Mouse, or the Campagnol; less than the Black rat; head larger and longer than that of the mouse; eyes larger and more projecting; ears longer and broader; legs longer. The upper surface and sides of the head and neck, superior parts of the body, and external surface of the fore feet, covered with fine short hair, of a fawn colour, tinged with black, each hair cinereus the greater part of its length, then fawn colour, then black at the extremity; side of the snout and inferior surface of the head and body, as well as the interior of the feet whitish, tinged with blackish or cinereus, where the hair is longest; on the breast, a yellowish spot, with a blackish tinge; tail brownish above, whitish beneath.

НАвіт. Living in woods and neighbouring fields; burrows in the ground and amasses provisions, which consist chiefly of grain; female producing more than once annually, and several at a birth.

Inhabit all Europe and United States; several varieties found in the vicinity of Philadelphia.

Two other species of Mus are noticed by Rafnesque as inhabiting the United States. 
1. Mus leucopus.

Char. Essent. Colour brownish-fawn above, white beneath; head yellow; ears large; tail as long as the body, pale brown above, gray beneath; feet white.

Dinensions. Total length five inches.

2. Mus nigricans, (black rat, or wood-rat.)

Char. Essent. Colour blackish above, gray beneath; tail black, longer than the body.

Dimensions. Total length, six inches. (Monthly Magazine, 1818.)

The last mentioned species is nothing more than the Mus rattus, Linn.

\section{Genus.}

Pseudostoma, Say, Long's Exped. to the Rocky Mountains, vol. i. p. 406.

Geomys, Rafinesque, Month. Mag.

characters.

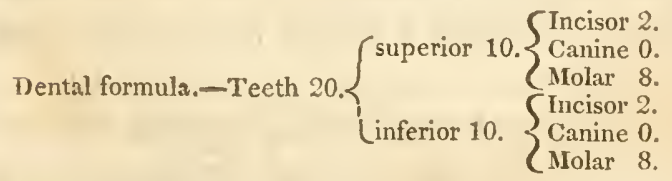

'The incisor's are not covered by the lips, but always remain exposed to view; they are strong, and truncated in their entire width at tip; the superior ones are each marked by a deep longitudinal groove near the middle. and by a smaller one at the inner margin. 
The molars, to the number of eight in each jaw: penetrate to the base of their respective alveoles without any division into roots; their crowns are simply discoidal, transversely oblong-oval, margined by enamel, but which is not elevated into crests or dividing ridges; the anterior tooth is double, in consequence of a profound duplicature in its side, so that its crown presents two oval disks, of which the anterior one is smallest. The molars of the upper jaw incline obliquely backwards; those of the lower jaw obliquely forwards.

Head and body large, so as to produce a clumsy aspect; cheek pouches voluminous, exterior to the mouth, from which they are separated by the common integuments; they are profoundly concave, opening downwards and towards the mouth.

Legs short; fore feet large; hind feet small; (Say.)

This animal is, with great propriety, separated from the genus Cricetus, (hamster, Lacep. Cuv. Geoff. Illig. from which it differs in the following particulars.

1. In having four molar teeth on both sides of each jaw. 2. In having five toes to the anterior feet. 3. In the form of the crowns of the molar teeth, which are tuberculous in the Cricetıs, and plane in the Pseudostoma. 4. In the length of the elongated nails on the fore feet. 5. In its enormous cheek pouches, and in other particulars to be observed in the description. 


\section{Species.}

1. Pseudostoma bursarius, Shaw, Trans. Lin. Soc. Lond. and General Zool. vol. ii. part 1. p. 100. pl. 133. under the name of Canada Rat.

Mus bursarius, Lin. 'Trans. vol. v. p. 227. pl. 8.

Mus saccatus, Mitchill, Med. Repos. 1821.

Geomys cinereus, Rafinesque, Monthly Mag. 1817, p. 45. Vulgarly Sand-rat, Goffer, Pouchedrat, Salamander, sc.

Char. Essent. Body covered with reddishbrown hair, plumbeous at base; feet white; anterior nails elongated; posterior ones short, and concave beneath.

Dimensions. Total length from nine to eleven inches.

Description. Body elongated, subcylindrical; hair reddish-brown, plumbeous at base; rather paler beneath; cheek pouches capacious, covered with hair both within and without; eyes black; ears hardly prominent; feet five-toed, white; anterior hair robust, with large, elongated, somewhat compressed claws; middle nail much the longest, then the fourth, then the second, then the fifth, the first being very short; posterior feet slender; nails concave beneath, rounded at tip, the external one very small; tail short, hairy at base, nearly naked towards the tip.

HABIT. Walking awkwardly, but burrowing with great rapidity, so that the difficulty of ob- 
taining specimens, may be in a great measure attributed to the facility with which the animal passes through the soil, in removing from the vicinity of danger; they cast up mounds of loose earth, which, like those of the blind rat, (Spalax typhlus) have no exterior opening; these elevations have been aptly compared by Lewis and Clark to the heaps of earth emptied from a flower-pot. The mounds are of various dimensions, from the diameter of a few inches to that of several yards. So entirely subterranean is the habit of this animal, that it is rarely seen; and many persons have lived for years surrounded by their little edifices without knowing the singular being by whose labours they are produced. (Say.)

Inhabit United States, from Lake Superior to Florida, and as far west as the Missouri.

The late Professor Barton, (Medical and Physical Journal,) was of opinion that the Mus bursarius of Shaw, was similar to the Toucan of Hernandez, and the Tuza or Tozan of Clavigero, and says that the cheek pouches in the figures given by Shaw, are represented in an inverted position.

We have seen the specimen described by Professor Mitchell, and observed that it had lost its tail. 


\section{Genus.}

Gerbillus, Desm. F. Cuvier.

Meriones, Illiger.

.Mus, Pallas, Pennant.

Dipus, Gmel. Bodd. Schreb. Oliv. Geoff. Sciurus, Erxleb.

Jerboa.

Dental formula.-Teeth 16. $\begin{cases}\text { superior } 8 . & \left\{\begin{array}{l}\text { Incisor 2. } \\ \text { Canine 0. } \\ \text { Molar 6. }\end{array}\right. \\ \text { inferior 8. } 8 . & \begin{array}{l}\text { Incisor 2. } \\ \text { Canine 0. } \\ \text { Molar 6. } 6 .\end{array}\end{cases}$

Molars similar in both jaws; the first being the largest, having three tubercles, which divide the crown equally lengthwise; the second having two, and the third, one; head elongated; cheeks rather projecting; ears moderately long, rounded at the extremity; anterior feet short, with four clawedtoes, and a rudiment of a thumb; the posterior long, or very long, terminated by clawed-toes, having each its proper metatarsal bone; tail long, more or less hairy.

Habit. Living in holes, which they dig in the earth; leaping forcibly with their hind legs; one species hibernates.

Inhabit the temperate climates of both contiments.

\section{Species.}

1. Gerbillus canadensis, Desm. Mamm. p. 321. 
Mus canadensis, Penn. Dipus canadensis, Davies, Trans. Lin. Soc. v. iv. p. 155. Canadian jerboa, Shaw, Gen. Zool. vol. ii. p. 192. pl. 161. (Encycl. pl. suppl. 11. fig. 3.)

This species has not been hitherto correctly described. 'The following description is taken from a well prepared specimen in the Philadelphia Museum.

Char. Essent. Yellowish above; white beneath; ears rather short; tail nearly naked, longer than the body, without a tuft of long hair at the extremity.

Dimensions. About the size of a mouse.

Description. Head small, narrow, pointed; facial line slightly arched; fore legs very short, four-toed, with a rudiment of a thumb; hind legs very long, five-toed; thigh and leg nearly of equal length; nails small, shaped like those of the mouse; ears of moderate length, with elevated and rounded borders, hairy within and without; colour yellowish-fawn above, whitish beneath; whiskers very long, fine and black; tail longer than the body, tapering, marked by several nodes, nearly naked, a few fine whitish hairs surround its extremity.

Inhabit the middle states; noticed by Maj. Long's exploring party at the base of the Rocky Mountains. Exped. to the Rocky Mcuntains, v. ii. p. 17. 


\section{Species.}

2. Gerbillus labradorius.

Mus labradorius, Sab. p. 661. append. to Franklin. Penn. Arct. Zool.

Description. Body nearly four inches long; forehead arched, and projecting so as to turn the nose towards the earth; mouth placed far below, small ; upper lip slit; ears large, round, and placed far back; whiskers long, black, and projecting. forming two tufts; back, brown above; under parts white, without a dividing line; hind legs long, (one inch and a half,) covered with short hair, having five toes, four long, a shorter one placed on the inside; fore feet short, with four toes; tail two inches and a half long, covered with black hair above, white below, showing the joints of the bones.

Inhabit Labrador. (As usual, Mr. Rafinesque has indicated numerous species.)

\section{Genus.}

Arctomys, Gmel. Schreb. Geoff, Cur. Lacep. Illig.

Mus, Linn. Pall. Bodd.

Glis, Briss. Erxleb.

Marmot.

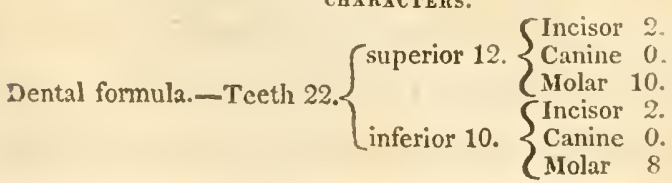


Incisors very strong, anterior face rounded; the inferior slightly compressed; molars simple, their crowns presenting ridges and blunt tubercles; the anterior and internal one is most projecting; body thick and clumsy; head large, flat above, without pouches for the most part; eyes large; ears short and rounded; feet robust, those before terminated by four distinct toes and a rudiment of a thumb; the posterior five-toed; nails of all the feet strong, compressed, and slightly hooked.

Tail hairy, moderate, or short.

HА віт. Burrowing; living in societies more or less numerous, becoming lethargic during the cold season; feeding on vegetables during the summer; becoming excessively fat; when tamed, they are sufficiently docile; and one species at least, (Monax) was never observed to eat animal food.

Inhabit both continents, some preferring northern and elevated countries.

\section{Species.}

1. Arctomys monax, Gmel. Schreb. tab. 208. Monax, Edwards, av. vol. ii. p. 104. Maryland Marmot, Penn. Quad. p. 270. N. 178. Glis monax, Erxleb. Le Monax, ou Marmotte du Canada, Buff. Cuniculus bahamensis, Catesby, Carolin. p. 79. tab. 79. Wood-chuck, in Maryland. Groundhog, in Pemnsylvania.

Chet . Essent. Brown above; paler on the sides 
and under the belly; snout bluish-gray and blackish ; tail about half the length of the body, covered with blackish hairs.

Dimensions. Total length from fifteen to eighteen inches.

Description. Body clumsy, low set; snout rather longer than in the Marmot properly so called; ears rounded ; nails long and sharp; colour ferruginousbrown, less deep on the flanks and inferior parts of the back, bluish-gray about the snout; tail covered with blackish hairs.

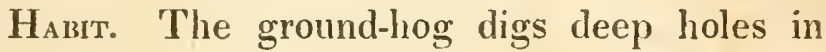
clover fields, or on the sides of hills, or under rocks in the woods in the neighbourhood of fields: these holes are deep and slanting, generally consisting of several compartments, with one or more entrances; they pass the winter in a state of lethargy; feed on herbs and fruits, but delight in clover, of which they destroy immense quantities; the female produces five or six at a birth: when tamed, they become sufficiently docile, and never eat animal food; when intercepted from their holes, they prefer giving battle to a dog rather than attempt to effect their escape by retreating; they are more than a match for a dog a size larger than themselves.

Inhabit North America; abound in the middle states. The above remarks are made from an individual that lived perfectly tame for several months. 


\section{Species.}

3. Arctomys empetra, Gmel. Schreb. tab. 210. Quebec Marmot, Penn. Quad. p. 270. n. 199. tab. 24 , fig. 2.

Glis canadensis, Erxleb. Mus empetra, Pall. (Encycl. pl. 67. fig. 4. under the name of Marmolte du Canada.)

Char. Essent. Colour blackish-brown, spotted with white above; ferruginous-red beneath; tail short, blackish at the end.

Dimensions. Total length eleven inches; of the tail two inches.

Description. Colour blackish-brown, spotted with white above, which is owing to the hairs of this part being blackish at their base, then annulated with white, and terminated with black; top of the head of a uniform brown, passing into reddish-brown on the occiput, and to black on the end of the snout; cheeks and chin of a dirty grayish-white; breast and fore paws red; feet black; tail rather short, with abundant black hairs; a variety has only the reddish teint less lively.

Навіт. Unknown.

Inhabit Canada and the environs of Hudson's Bay.

\section{Species.}

3. Arctomys ludoviciani, Ord, Guthrie's Geog. v. ii. p. 302, 1815. Say, Exped. to the Rocky 
Mountains, v. i. p. 451. Arctomys missouriensis, Warden's descrip. of the United States, vol. v. p. 627, 1820. Prairie dog, Lewis and Clark's Exped. up the Missouri. (A well prepared specimen in the Philadelphia Museum, presented by Lewis and Clark.)

Char. Essent. Colour a light dirty reddish. brown above, intermixed with some gray, also a few black hairs, this hair is of a dark lead colour next the skin, then bluish-white, then light reddish, then gray at tip; the lower parts of the body are of a dirty white colour.

Dimensions. Total length sixteen inches; of the tail two and three quarter inches; hair at its tip three quarters of an inch.

Description. Head wide and depressed above; eyes large; iris dark brown; ears short and truncated; whiskers of moderate length, and black; a few bristles projecting from the anterior portion of the superior orbit of the eye, and also from a wart on the cheek; nose rather sharp and compressed; all the feet five-toed, covered with very short hair, and armed with rather long black nails, of which the anterior one of the fore foot nearly attains the base of the next, and the middle one is half an inch in length; the thumb is armed with a conical nail, three-tenths of an inch in length; the tail is rather short, banded with brown near 
the tip, the hair excepting near the body is not plumbeous at base.

HАвіт. This interesting little animal is very sprightly, and has received the inappropriate name of Prairie dog, from a fancied resemblance of its warning cry to the hurried barking of a small dog; this sound may be imitated with the human voice. by the pronunciation of the syllable, cheh-chehcheh, in a sibilated manner, and in rapid succession, by propelling the breath between the tip of the tongue and the roof of the mouth.

As particular districts, of limited extent, are in general occupied by the burrows of these animals, such assemblages of dwellings are denominated Prairie dog villages, by hunters and others. These villages differ widely in the extent of surface which they occupy; some are confined to an area of a few acres; others are bounded by a circumference of many miles. The entrance to the burrow is at the summit of the little mound of earth cast up by the animal during the progress of excavation. These mounds are sometimes inconspicuous, but generally somewhat elevated above the common surface, though rarely to the height of eighteen inches. Their form is of a truncated cone, on a base of two or three feet, perforated by a comparatively large hole at the summit, or in the side. The whole surface, but more particularly the summit, is trodden down and compacted; the hole descends vertically one or two feet, 
whence it continues in an oblique direction downwards. A single burrow may have many occupants, as many as seven or eight individuals have been observed sitting upon one mound. They delight to sport about the entrance of their burrows in pleasant weather; at the approach of danger they retreat to their dens; or when its proximity is not too immediate, they remain barking, and flourishing their tails on the edges of their holes, or sitting erect to reconnoitre; when fired upon in this situation they never fail to escape; if killed, they instantly fall into their burrows, beyond the reach of the hunter. They pass the winter in a lethargic state, and defend themselves from its rigours by accurately closing up the en. trance of the burrow: they construct for themselves a very neat globular cell with fine dry grass, with an aperture at top large enough to admit the finger, and so compactly formed, that it might almost be rolled over the floor without receiving injury. The burrows are not always equidistant, though they occur usually at intervals of about twenty feet. (Say.)

'These animals would appear to be very innocent, as we are informed by Gen. Pike, (in his Expedition,) that he has observed " the Marmot, the Rattle-snake, the Horned frog, (Agama cornuta, nob.) of which the prairies are full, and the Land turtle, seek refuge in the same hole." $\mathrm{He}$ further states that the Indians name this animal 
"Wish-ton-wish," which they pronounce with a sharp voice, in order to mimic the voice of the animal.

Inhabit North America, abounding in the Missouri country.

Species.

4. Arctomys tridecemlineata.

Sciurus tridecemlineatus, Mitchill, Medical Repository, No. 2. vol. vi. January, 1821.

Arctomys hoodii, Sabine, Trans. Lin. Soc. vol. xiii. p. 590. 1822.

Striped and spotted Ground-squirrel, Say, Long's Exped. to the Rocky Mountains, vol. ii. p. 174.

This beautiful little animal has been improperly placed under the genus Sciurus, from which it is essentially different, and corresponds with the genus Arctomys in the following particulars. 1. In the form and appearance of the whole body in general; 2 . in the form of the head and ears; 3 . in the length, direction, and form of the tail ; 4 . in the form and proportion of the legs; 5 . in the form and length of the nails; and, 6. in some of its manners and habits. In justice to Mr. Desmarest, we must remark that he has expressed some doubts of the propriety of arranging it under the division in which he had placed it, but not having seen the animal, he was unable to say which genus it most resembles. 
Char. Essent. Colour a deep chesmut above, striped, with six white lines, alternating with an equal number of longitudinal rows of white spots; white beneath.

Dimensions. Total length six inches five-tenths; of the tail, less than two inches.

Description. Head sniall, rather flattened above; snout conical; body elongated, low set, thickest behind; extremities short, nearly of equal length; feet covered with hair even to the base of the nails; colour of the animal above of a deep chesnut, and marked with six longitudinal lines, commencing at the occiput, and running the whole length of the body, alternating with a series of white oblong spots, commencing at the shoulders, and continuing along the body; the middle dorsal line is composed of these spots, about eighteen in number, which commence at the nucha and are continued to the base of the tail; throat, breast and belly nearly white; tail short, surrounded with hairs longer than on the body, rather bushy, and of a whitish colour, mixed with black; feet whitish, covered with fine hairs, and terminated by five clawed toes before and behind. Nails on the three middle toes of the fore feet long, subulate, blackish; the middle toe nail is the longest; the external and internal toes and nails very short; hind feet broad and flat; the three middle claws nearly equal; the external and internal nails like those of the fore foot very short. The whole ani- 
mal resembles the Arctomys missouriensis, except in colour, size and markings.

Tеeтн. Molars five above and four below, crowns rather concave, borders slightly tuberculous, roots long and distinct from each other; superior incisors rather small, cuneiform, plane on the anterior surface, and of a yellow colour; inferior incisors proportionably long, nearly cylindrical at base, chisel shaped at top, separate and divergent. Furnished with large cheek pouches lined with hair both internally and externally.

Habit. According to Mr. Say, (who observed this animal when descending the Arkansa,) they burrow in the earth, and do not voluntarily climb trees. 'They inhabit an extensive portion of North America, extending at least from the more northern lakes to the Arkansa river, and most probably in that direction into Mexico, and westward to the Rocky Mountains. 'They were not uncommon in the vicinity of Engineer Cantonment. According to Sabine, they inhabit also the northern parts of Canada.

Mr. Nuttall long since obtained specimens of this species near the Mandan village on the Missouri, and in the year 1814 he presented skins of it to several of his scientific friends in London. He states that he has seen tippets worn by the Indians of the Upper Missouri, which were made of the skins of this elegant species, sewn together. 
(A specimen in the Philadelphia Museum, brought by Major Long's exploring party.)

\section{Species.}

5. Arclomys franklinii, Sabine, Trans. Lin. Soc. vol. xiii. tab. 27 . p. 587.

Gray American Marmot.

Char. Essent. Head furnished with small ears; snout very obtuse; tail elongated; body variegated fuscus.

Dimersions. Total length, not including the tail, eleven inches; of the tail to the end of the hair five inches.

Description. Face broad, nearly covered with rigid hairs (black and white;) nose bare and very blunt; ear's broad, covered with short hairs; short black whiskers on the cheeks, and similar hairs grow thinly distributed above and below the eyes; throat dusky white; upper incisors short, and of a reddish colour; inferior incisors twice the length of the upper, and paler; upper part of the body with short hairs, dark at the base, in the middle dingy-white, then first black, next yellowish-white, and tipped with black; the whole a variegated dark yellowish-gray; the hair on the sides is longer, has less black, and is withont the yellow tinge; that on the belly is dark at base, and dingywhite above; tail with long hairs banded with black and white, tipped with white, the whole appearing indistinctly striped with black and 
white; feet broadish; toes thin and gray, covered with hairs; on the fore feet the second from the inside is longest; the outer shortest, and placed far back; the three middle hind toes nearly equal; the extremes shorter and far back; claws horn colour, those on the fore feet long and sharp, those on the hind toes shorter.

\section{Species.}

6. Arctomys richardsonii, Sabine, Trans. Lin. soc. vol. xiii. tab. 28. p. 589.

Tawny American Marmot.

Char. Essent. Ears short; snout acute; tail moderate ; body fuscus.

Dinersions. Nearly the size of the preceding species, but more slender.

Description. Top of the head covered with short hairs, dark at the base and light at the tips; face narrow; nose tapering and sharp, bare at the end, above covered with short light brown hairs joining and mixing with those on the top of the head; ears oval and short; cheeks swollen, covered with light brown hairs; whiskers short, growing from the cheeks, and a few long and rigid hairs above the eyes; throat dirty white; upper part of the body covered with soft short hairs, lark at the base, above fulvous; in the middle of the back, the hairs are like those on the top of the head, but lighter; sides with longer hairs, showing dark at base when raised. the ends a 
smoky white, the under parts similar, but a little dashed with ferruginous; tail three inches and a half long to the end of the hairs, slender, and thinly covered with long hairs, which are at the base of the same colour as the body, but above of three distinct colours, first black, then dark, and lastly light at the upper extremity; legs rather long and slender; feet narrow ; claws horn colour, arched and sharp; on the inner side of the fore feet, a small toe placed far back, with an obtuse claw, in which it differs from the other species of this genus; outer toe and claw of the fore feet much shorter than the remaining three, of which the middle one with its claw is longest; of the hind toes, the two extremes shorter and placed back, the others nearly of equal length.

\section{Species.}

7. Arctomys pruinosa* Gmel. Syst. Nat. i. 144. 'Turt. Linn. Hoary Marmot, Penn. Hist. Quad. ii. 389. Penn. Arct. Zool. i. 112. Schreb. Quad. 745, Shaw's Zool. iii. 121.

Size of a rabbit; tip of the nose black; ears short and oval; cheeks whitish; crown dusky and tawny; hairs usually rude and long, those on the back, sides, and belly, cinereus at the root, black in the middle, whitish at the tip, so that the animal has a hoary appearance; tail black, mixed with rust colour; legs black; claws dusky. 
This specimen was supposed to have come from the northern parts of North America.

\section{Species.}

8. Arctomys parryii, Dr. Richardson's Appendix to Franklin's Expedition.

Gray Arctic Marmot.

Ground-squirrel, Hearne's Journey, p. 141.

Quebec Marmot, Foster, Philos. Trans. Ixxii. p. 378.

.Arctomys alpina, Parry's Narrative, 2nd voyage, p. 61 .

Char. Essent. "A. palmis pentadactylis; rostro obtusissimo; buccis sacculiferis; auriculis brevissimis; cauda elongata, apice nigra; corpore supra maculis albis nigrisque confluentibus marmorata, subtus ferrugineo."

Dinensions. A size larger than the $\boldsymbol{A}$. franklinii, and less than the empetra. 'Total length, to the base of the tail, twelve to fourteen inches; trunk of the tail four inches, with the hair five inches and a half.

Description. Body broad and flattish, with thick legs; head depressed; nose blunt and covered with a dense coat of short brown hairs; margin of the mouth hoary; eyes large and dark coloured; orifice of the auditory passage large; ear very short, consisting merely of a flat, semi-oval flap, projecting about two lines; pouches ample, opening into the mouth anterior to the grinders; teeth, primores 
white, with chisel shaped cutting edges, wearing away, and frequently channelled inside, those in the upper jaw short and somewhat truncated; lower one-third longer, rather narrower, and terminated by nearly a semicircular outline; molars five above and four below, posterior largest; some adults with only four above, their crowns are bounded by an irregular bending plate of enamel, intersected by two transverse ridges of unequal height, and presenting a few obtuse points; back covered with soft fur, consisting of a soft down of a dark smoke-gray at the roots, pale fresh-gray in the middle, and yellow-gray at tips; this arrangement produces a crowded assemblage of ill defined irregular and confluent whitish spots, mar gined and scparated by black and yellowish-gray; these spots assume a transverse arrangement on the posterior part of the back; throat and all underneath brownish-red and brownish-yellow, or rather a colour intermediate; colours of the back and belly run into each other. Tail flattish and subdistichous, the hairs of which the animal is capable of expanding like a feather, in which state the tail is brown along the middle, tipped and margined for two-thirds of its length with black; Eeet with short depressed claws, large, blackish, slightly arched, and grooved underneath; on the inside of the fore feet, and high up, there is a small toe or thumb armed with a small nail; yalms naked and with callous protuberances, 
three at the base of the toes, the thumb inserted into the largest.

Habit and geographical range like the preceding species.

\section{Genus.}

Sciurus, Briss. Linn. Erxleb. Bodd. Cuv. Geoff. Illig. squirrel.

\section{CHanactens.}

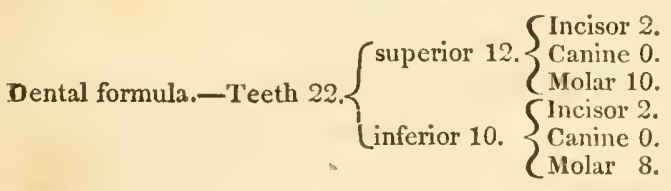

(Note.-The fifth molar exists only in the young individual.)

Superior incisors flat before, and cuneiform at the extremity; the inferior pointed, and laterally compressed.

Molars with tuberculous crowns.

Body elongated; head small; ears straight, moderate and rounded; eyes large. Anterior feet with four long toes, distinct, armed with compressed and horned nails, with a tubercle covered with an obtuse nail, in place of a thumb; posterior feet very large; tarsi very long; five elongated distinct toes, with hooked nails.

'Tail long, often furnished with hairs disposed in two rows like the feathers of a quill: distichous. 
Eight mammæ, of which two are pectoral; six ventral.

НАвіт. These animals, evidently constructed for climbing, pass their life on the summits of trees; their posterior extremities, much longer than their anterior, are disposed for embracing the branches; they are full of life and agility, and feed principally on dried fruits, which they carry to the mouth with their hands, making use of their stunupy thumbs as points of support. They construct near the tops of high trees, a round nest, formed of small branches of leaves and of moss. 'They bring forth four or five young at a birth.

Inhabit the whole earth, with the exception of New Holland, and the greatest part of South America.

1. Sub-genus, squirrels properly so called.

Species.

1. Sciurus cinereus, Schreb. Tab. 213. Sciurus caroliniensis and cinereus, Gmel. Ecureuil gris de Caroline, Cuv. Reg. Anim. Petit-gris, Buff. (Encycl. pl. 74. fig. 3. Le pitit gris.) Gray Squirrel.

Char. Essent. General colour, of a grayishfawn, spotted with black above; white beneath; borders of the flanks, a fawn colour, more or less pure; ears without pencils of hair.

Dimensions. Total length ten inches six lines; 
of the head two inches six lines; of the ears eleven lines; of the trunk of the tail seven inches six lines.

Description. Superior parts of the head and neck, as well as the back, covered with hairs, gray at their base, and afterwards divided into two or three zones, alternately of a clear fawn, and black, which produces a general complexion of gray, approaching to yellow; sides of the neck, and particularly the haunches, spotted with white; flanks slightly spotted with black, which leaves the fawn colour nearly pure; abdomen white; legs covered with gray hair at their base, and reddish-fawn at their extremities; sides of the head and snout reddish; ears rounded, covered with very short hair; whiskers black; tail composed of hair marked with zones alternately fawn and black, and terminated with white; from whence it results when the tail is flattened, that it is surrounded from right to left with a white line, then with a black line, and its middle fawn colour, spotted with black.

V ARIETY. Blackish-gray, more or less approaching black.

Habit. Living in large troops and feeding on nuts and grain; very destructive to the produce of the latter. In winter they retire to holes in old trees where they have amassed their provisions, and where they bring forth their young.

Inhabit Pennsylvania and most parts of the 
United States; they appear to retire before the intrusion of a smaller species, (the $\boldsymbol{S}$. hudsonius.) In 1749 , a premium of three pence a head was offered for their destruction, which amounted in one year to $8000 l$. sterling, which is equal to about $1,280,000$ individuals killed.

\section{Species.}

2. Sciurus capistratus, Bosc. Ann. Mus. t. 1. p. 281. Sciurus vulpinus, Gmel.? Schreb. 213. B. Brown, Nouv. Illust. de Zool. pl. 47. Charlevoix, t. 1. p. 237. Ecureuil à Masque, Cuv. Regn. Anim. t. 1. p. 205. (Encycl. pl. suppl. ii. fig. 2.) Fox Squirrel.

Char. Essent. Colour iron-gray or black above; head black, with the end of the snout always white, as are also the ears.

Dimensions. Total length about two feet from the end of the snout to the extremity of the tail, and three inches in diameter.

Description. Head oval, rather elongated, black at its summit; cheeks black, mixed with brown; top of the nose and lips white; ears round, white, hair on the exterior longer than on the interior; body covered with two sorts of hair, the one black, with the superior half white, the other white with the superior half black; chin, breast and belly white; feet grayish-brown; tail as long as the body, covered with long hairs, black at their base, white at their extremity, and the intermediate 
parts of which are twice annulated with white, and twice with black; from whence it results that the tail, when it is flattened, appears to have a double border, white and black.

Var. 1. S. capistratus niger. V. 2. S. capistratus nigriventer.

Habit. Dwelling in pine forests; the seeds of the pine constitute their principal nourishment; they enter in heat during the month of January; their young are capable of running by the month of March; they differ little for the rest in their habits from the common gray squirrel.

Inhabit New Jersey and South Carolina, principally in the neighbourhood of Charleston, where they are found in the company of the gray Squirrel.

\section{Species.}

3. Sciurus rufiventer, Geoff: Collect. du Mus, Desm. Nouv. Dict. d'Hist. Nat. t. 10. p. 103.

Char. Essent. Colour, grayish-brown above; a lively red beneath; feet brown; tail nearly the length of the body; the colour of the back at base blackish at the extremity.

Dinensions. Total length six inches six lines; tail without the hairs nearly the length of the body.

Description. Reddish-brown, bordering on black on the head, neck, back and flanks; feet reddish-brown; these hairs are slate-gray at base; beneath the jaws and throat dirty reddish-white; 
belly and inside of the legs nearly pure red; whiskers black, and as long as the head; ears reddish, and covered with short hairs; extremities of the feet of a blackish-brown; tail brownish at base, blackish beneath and at the extremity, reddish on the middle upper surface.

Inhabit southern states. The above description is taken from a specimen in the Philadelphia Museum, brought from near New Orleans, and is, without doubt, distinct from the Gray Squirrel.

\section{Species.}

4. Sciurus niger, Linn. Erxleb. Screb. tab. 215. Sciurus mexicanus, Hernandez, Mex. p. 582. fig. 2. Black Squirrel, Catesby, Carrol. vol. ii.p. 73. Bartram, Voy. in North Amer. vol. ii. p. 31. (Encycl. pl. 74. fig. 2.)

Char. Essent. Colour deep black above, brownish-black beneath; ears black and not pencilled with hair; tail black.

Dimensions. Total length about eight inches, tail proportionably shorter than that of the gray squirrel.

Description. Top of the head, back, tail, and extremities of the feet, covered with hair of a deep black colour, without any mixture of red or fawn colour; throat, breast, and belly, of a black approaching to a brown colour; hair of the flanks black, and having each a brown ring, which diminishes abnut these parts the intensity of the 
black colour; ear's short and black; hair of the tail ringed like the flanks; covering consisting of brown fur, traversed with long hairs, which are alone apparent; each of these are brown at base, then marked with a teint more clear for a small extent, and terminated with black; those of the posterior part of the back being the longest and entirely black, as well as those on the top of the head.

Some individuals have white at the end of the tail, nose and feet, also like those of Catesby's, (copied in the Encyclopredia) around the neck.

Inhabit North America. This species differs from the black variety of the $\boldsymbol{S}$. capistratus in its small size, the softness of its hair, and because its nose and ears are not regularly white. It is separated from the black variety of the Gray Squirrel by the shortness of its tail.

\section{Species.}

5. Sciurus magnicaudatus.

Sciurus macrourus, Say, Long's Exped. to the Rocky Mountains, vol. i. p. 115.

The specific name by which this species has been designated, has already been applied to designate a squirrel totally different, viz. the Ceylon Squirrel, Penn. Quad. p. 408. which is the $\boldsymbol{S}$. $m \boldsymbol{a}$ crourus, Gmel. Schreb. tab. 21\%.

Char. Essent. Rody above on each side mixed 
gray and black; side of the head and orbits pale ferruginous; cheek, under the eye and ear, dusky.

Dimensions. From the nose to the tip of the trunk of the tail one foot seven inches and onefourth; trunk of the tail from the base to the tip nine inches one-tenth; length of the ears threefourths of an inch; tail more voluminous even than that of the $\boldsymbol{S}$. cincreus.

Description. Fur on the body plumbeous, black at base, then pale cinnamon, then black, then cinereus, with a long black tip; ears bright ferruginous behind, the colour the same to the base of the fur, which in the winter dress is prominent beyond the edge; within dull ferruginous, the fur slightly tipped with black; whiskers black in about five series, of which the four inferior ones are more distinct, hairs slightly flattened; mouth margined with black; teeth reddish-yellow; head beneath, neck and feet above, pale ferruginous; belly paler; fur pale plumbeous at base ; palms black ; anterior toes, four; thumb tubercle not longer than its lobe in the palm, and furnished with a broad, flat nail; posterior toes, five; tail beneath bright ferruginous, the colour extending to the base of the fur, with a submarginal black line; above mixed ferl'uginous and black; fur within pale cinnamon, with the base and three bands black; tip ferruginous.

The fur of the back in the summer dress is from. three-fifths to seven-tenths of an inch long; but in the winter dress the longest hairs on the middle 
of the back are one inch and three-fourths in length, but the colours do not vary, and it is only during the winter that the ears are fringed. (Say.)

Inhabit the United States. The most common species on the banks of the Missouri river.

\section{Species.}

6. Sciumus quadrivittatus, Say, Long's Exped. to the Rocky Mountains, vol. ii. p. 45.

Char. Essent. Head brownish, intermixed with fulvous, marked with four white lines; sides fulvous; beneath whitish.

Dimensions. Total length four inches and onefourth (without the tail;) of the tail three inches; of the hair at the tip of the tail nearly one inch.

Description. Head brownish, marked by four white lines, of which the superior one on each side passes from the tip of the nose immediately over the eye to the superior base of the ear, and the inferior one passes immediately beneath the eye to the inferior base of the ear; ears moderate, semi-oval; incisors reddish-yellow; back with four white broad lines, and alternate mixed black and ferruginous ones; sides fulvous; beneath whitish; tail moderate, hair black at base, then fulvous, black in the middle, and pale-fulvous at tip; beneath fulvous with a sub-marginal black line; thumb of the anterior feet, a prominent tubercle.

II Aвıт. Nestling in holes, and on the edges of rocks, and do not ascend trees by choice. The 
nest is composed of a most extraordinary assemblage of the burs of the Xanthium, branches, and other portions of the large upright Cactus, small branches of pine trees, and other vegetable productions, sufficient in some instances to fill the body of an ordinary cart; what the object of so great, and apparently so superfluous, an assemblage of rubbish may be, we are at a loss to conjecture; we do not know what peculiarly dangerous enemy it may be intended to exclude by so much labour; their principal food, at least at this season, (July) is the seeds of the pine, which they readily extract from the cones.

Inhabit the Rocky Mountains, about the sources of the Arkansa and Platte. (Say.) A specimen in the Philadelphia Museum.

\section{Species.}

\%. Sciurus lateralis, Say, Long's Exped. to the Rocky Mountains, vol. ii. p. 46.

Char. Essent. Above brownish cinereus; each side of the back marked with a dull yellowishwhite dilated line, broader before.

Dimensions. Rather larger than the $\boldsymbol{S}$. striatus.

Description. Above brownish-cinereus, intermixed with blackish; on each side of the back is a dull yellowish-white dilated line, broader before; margined above and beneath with black, originating upon the neck anterior to the shoulder, and not attaining the origin of the tail; no 
appearance of a vertebral line; thigh, neck, antefior to the commencement of the white line, and top of the head, tinged with ferruginous; orbit whitish; tail short, thin, with a submarginal black line beneath; nails of the anterior feet elongated; thumb tubercle furnished with a broad nail; sides dull yellowish-white; beneath pale, intermixed with blackish. (Say.)

Inhabit about the base of the Rocky Mountains, where they were first observed by Lewis and Clark, on their expedition to the Pacific Ocean. A specimen in the Philadelphia Museum, brought by the exploring party under Maj. Long.

\section{Species.}

3. Sciums grammurus, lined tail squirrel, Say, Long's Exped. to the Rocky Mountains, v. ii. p. 72.

Char. Essent. Body cinereus; fin very coarse; three black lines on each side of the tail.

Dinensions. Length to the origin of the tail eleven inches; of the tail nine inches.

Description. Body cinereus, more or less tinged with ferruginous; fur very coarse, much flattened, canaliculate above, plumbeous or blackish at base, then whitish or ferruginous, tip brownish; above the neck and shoulders the whitish is prevalent; from the middle of the back, the sides, and the sxtrrior surface of the legs, the ferruginous colour 
prevails, the terminal brown of the feet being obsolete; superior and inferior margins of the eyes white; tail moderate, whitish ; fur trianulate with black; the base and tip of each hair being whitish; beneath whitish, tinged with ferruginous; thumb tubercle armed; iris burnt amber colour, pupil black.

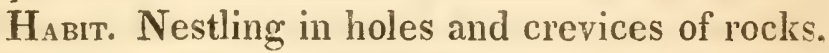
and do not appear to ascend trees voluntarily; in the stomachs of those killed, were found the buds and leaves of a few small plants, common among the rocks.

Inhabit near the Rocky Mountains on the head of the Arkansa; frequent about the naked parts of the sand stone clifts, or where are only a few cedar bushes. (Say.)

\section{Species.}

9. Sciurus striatus, Klein. Pallas, Glir. p. 378. Gmel. Schreb. Tab. 221. Sciurus lysteri, Rai, Syn. Quad. p. 216. Sciurus caroliniensis, Briss. Regn. Anim. p. 155. Le suisse, Buft. t. x. pl. 28. Vulgarly the Ground squirrel. (Encycl. pl. 76. fig. 4.) Desm. Mamm. p. 339.

Char. Essent. Body a brown fawn colour above, with five longitudinal brown rays and two white ; rump red; inferior parts white; tail blackish above, red and bordered with black beneatl.

Dimersiors. Total length five inches; of the 
tail two inches six lines; of the head one inch six lines.

Description. Top of the head, reddish-graybrown colour; eye-lids whitish; a black line parting from the external of the eye is directed towards the ear; a reddish-brown line on each cheek; ears short, rounded, covered with very fine hair, of a reddish-brown within, and of a grayish-brown without on the anterior border, and of a whitish-gray on the posterior; top of the neck, shoulders, and base of the dorsal fur of a grayishbrown, spotted with white; five longitudinal black bands slightly touched with red on the body, the intermediate commencing at the occiput, and the lateral at the shoulders, all terminating towards the rump, which is of nearly a lively red; inferior parts of the flanks and sides of the neck of a more pale red; two white bands, one on each side, separating the two lateral black bands; exterior surface of the fore feet, gray-fawn colour; exterior of the thighs and hind feet above red; superior lip, chin, throat, belly and face, with the interior of the extremities, of a dirty brown; tail reddish at its base, blackish above and red beneath, with a black border. All the hairs of the superior parts of the body, are gray at base; those of the tail red or reddish at base, then black, and terminated with dirty white.

Habit. Digging holes in the earth having two openings and as many lateral branches, in which 
holes they accumulate provisions for winter, which they transport in their chcek pouches; such artiticles as seeds, roots, nuts, \&c. Copulate in March.

Inhabit Northern Asia, from the Kama and the Dwina to the extremity of Siberia; North America, from Canada to Carolina, and west of the Mississippi. (Variety, perfectly white, albino.)

\section{Species.}

10. Sciurus hudsonius, Gmel. Schreb. Tab. 214. Foster, Act. Angl. v. Ivii. p. 378. Penn. Syn. Quad p. 280. 'Tab. 26. fig. 1. Pall. Glir. p. 376. S. vulgaris, Var. F. Erxleb. (Encycl. pl. 75. fig. 1.) vulgarly the Chick-a-ree.

Char. Essent. Colour reddish-brown above, whitish cinereus beneath; a single black line on each flank.

Dinensions. Total length seven inches seven lines; of the head one inch ten lines; of the tail five inches.

Description. Superior parts of a reddish-brown, more or less deep, and more or less spotted with black; top of the head and anterior part of the members of the same colour, but of a complexion rather nore clear; lower jaw, beneath the throat, breast, belly, and anterior surface of the thighs, of a dirty white, lightly tinged with yellow; a well defined black line on each flank, separating completely the colour of the back from that of the 
belly; tail of a similar colour to the body, bordered with black; whiskers very long and black.

Inhabit North America, from Hudson's Bay to the middle states.

Noте.-S. rubralineatus, (Warden, Desc. des etats unis,) is probably a variety of the $\mathbf{S}$. hudso. nius.

\section{Species.}

11. Sciurus ludovicianus, ${ }^{*}$ Custis, Barton's Med. and Phys. Jour. vol. ii. part 2. p. $4 \%$.

Char. Essent. Body and upper part of the tail dark gray; the belly, inside of the legs and thighs, and under part of the tail, reddish-brown; ears not bearded; tail longer than the body, very broad.

Dimensions. About the size of the Sciurus vulpinus.

Inhabits the shores of Red River.

\section{Genus.}

Pteromys, Cuv. Geoff. Illig.

Sciurus, Rai, Briss. Klein. Linn. Gmel. Erxleb. Bodd.

$$
\text { Dental formula.--Teeth 22. } \begin{cases}\text { superior 12. } & \begin{array}{l}
\text { Incisor } 2 . \\
\text { Canine } 0 . \\
\text { Molar 10. }
\end{array} \\
\text { inferior 10. } & \begin{array}{l}
\text { Incisor 2. } \\
\text { Canine } 0 . \\
\text { Molar } 8 .
\end{array}\end{cases}
$$

Note--In very old individuals the two anterios molars of the upper jaw are wanting. 
The terminations of the superior incisors cuneiform, with their anterior surfaces smooth; the two inferior laterally compressed and sharp.

The crowns of the molars are furnished with blunt tubercles.

Head slightly rounded; snout prolonged; ears rounded; eyes large.

Anterior feet with four elongated toes, armed with elongated and compressed claws; a rudimentary thumb furnished with an obtuse nail; the posterior feet disposed for climbing, with five clawed toes, very much separated; skin of the flanks very extensive, clothed with hair above and below, joining the anterior with the posterior members, and forming a species of parachute; an osseous appendage to the feet, destined to sustain this membrane of the flanks.

'Tail long, hairy, sometimes distichous; hair generally soft.

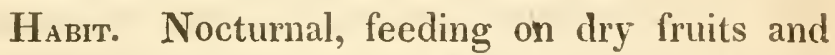
nuts like the squirrels, to which they are nearly related in their habits.

Inhabit North America and Asia, Southern Asia, and the Indian Archipelago.

\section{Species.}

1. Pteromys volucella, American Flying Squirrel. Sciurus volucella, Pallas, Nov. Quad. e Glir. Ordin. p. 353. Cmel. Syst. Nat. Schreb. tab. 222 . 
Polatouche, Buff. t. 10. pl. 21. Shaw, Gen. Zooi. vol. ii. part 1. p. 155. tab. 150.

Assapan, F. Cuv. Mamm. Lithogr. 8th livraison. (Encycl. pl. 7\%. fig. 4.)

Char. Essent. Colour reddish-gray above, white beneath; tail nearly as long as the body; lateral membranes presenting a simple lobe posterior to the wrists.

Dinersions. Total length four inches ten lines; of the head one inch six lines; of the trunk of the tail three inches seven lines.

Description. Superior surface of the head, of the body, of the tail, and exterior surface of the limbs, of a gray colour, with a slight brush of red; the hairs of these parts being cinereus at base, and reddish-yellow at their extremity; eyes surrounded with a blackish-ash colour, with a white spot above each ; borders of the membrane also passing into a brown above; beneath the body, from the end of the snout to the origin of the tail, white, with a slight teint of yellow on the borders of the membrane, and on the imer sides of the thighs and legs; upper surface of the tail of a clear brown colour, the inferior of a yellowish-white; whiskers black, and about two inches in length.

НАвтт. Living in little troops on trees, feeding on nuts, seeds, grains, buds of the birch tree, \&c.

Inhabit the United States, from Canada to Virginia. 
Genus.

Hystrix, Briss. Linn. Schreb. Cur, Geof: Lacep. Illig. Klein.

Cavia, Klein.

Coendu, Lacep.

Porcupine.

CHAIACTIRS

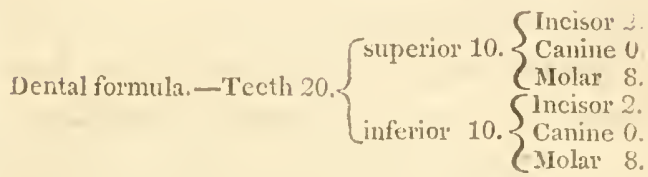

Superior incisors very strong, smooth anteriorly. cuneiform at their extremity; the inferior strong and slightly compressed laterally.

Molars compound, with flat crowns, surrounded with a line of enamel, which traverses more or less deeply the external and internal borders, and appears to cut the tooth into two parts; a few circular lines of enamel of a larger or smaller size.

Head strong; snout thick and tumid; ears short and rounded; tongue beset with spiny scales; anterior feet four-toed, posterior five-toed, all armed with powerful nails; a rudiment of a thumb with an obtuse nail to the fore foot.

Spines more or less long on the body, sometimes internixed with hair: tail more or less long, sometimes prehensile.

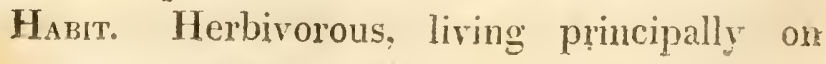


fruits, grains and roots; digging holes, or else living in the hollows of old trees.

Inhabit North and South America, Southern Europe, Africa, and India.

1. Subgenus. Porcupines properly so called: tail not prehensile.

Species.

1. Hystrix dorsata, Gmel. Erxleb. Bodd. Schreb. tab. 169. Hystrix hudsonis, Briss. Regn. Anim. p. 128. Hystrix pilosus americanus, Catesby, Carol. app. p. 30. Cavia hudsonis, Klein. Quad. p. 51. Urson, Buff. 1. 12. pl. 55. (Encycl. pl. 65. fig. 1.)

Bear Porcupine.

Char. Essent. Spines short, in part concealed by brown hair; tail elongated; no mane; long bristles on the head and neck.

Dinensions. Total length two feet one inch: of the tail eight inches; the longest nails one inch three lines.

Description. Snout thicker and shorter than that of the common Porcupine; ears very small, entirely covered by the hair; base of the hairs very thick, and beset with spines, the largest of which are two inches and a half long, and are situated about the rump; these spines being partly white and partly brown or blackish, tipped with black; those of the rest of the body are covered with long, strong hairs, of a blackish-brown colour. 
rerminated with yellowish-white; a cinereus coloured down next the skin; simple stiff bay-coloured hair on the tail; belly, legs and feet equally covered with hair, but of a blackish-brown, as well as the snout.

Навіт. They make their nests or dwelling place beneath the roots of hollow trees; they fly the water and fear to soil themselves; they sleep much, and feed principally on the bark and leaves of the hemlock, (pinus canadensis) and basswood, (tilia glabra;) they have been known to strip trees of their foliage, in the same manner as the sloths; they are, however, fond of sweet apples, corn, \&c. which they eat holding in their fore claws in a sitting posture. The Indians say they are excellent food. When they are discovered on the ground, which seldom happens, they do not strive to get out of the way, but on being approached, immediately spread the spines situated near the tail over the whole of the back.

The female brings forth annually, three or four at a birth, after a gestation of about forty days.

Inhabit the northern parts of the United States. According to the account of Mr. F. Cozzens, (Vid. Annals of the Lyceum of Nat. Hist. of New York, vol. i. p. 190, 1824, ) to whom we have been chiefly indebted for the above details concerning the habits of this singular animal : of late years they have multiplied greatly, and have become numerous near the Oneida lake, and in the 
north-western part of New York. 'Their' quills are dyed of different colours by the Indians, and used as ornaments in giving a borler to moccasins, wampum, leggings, \&c.

\section{Genus.}

Lepus, Briss. Jimn. Schreb. Cuv. Geoft. Lacep. lliig. The Hare.

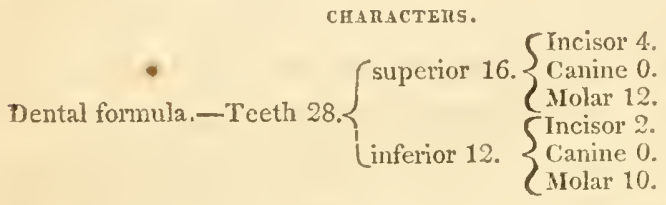

Superior anterior incisors, large and cuneiform, having a longitudinal groove in front; the posterior small and accurately applied in the direction of their length to the superior; inferior incisors with cutting square edges; the six superior molars on each side (of which the anterior is smallest.) have flat crowns, with transverse, projecting plates of enamel; inferior molars nearly similar to the superior. Head rather large; snout thick; ears very long; ey es very large, projecting laterally; interior of the mouth furnished with hairs.

Anterior feet rather short and thin, five-toed; the posterior feet very long, four-toed; all the toes laying close to each other, and armed with moderate sized nails, slightly arched; palms and soles hairy. 
'Tail short, hairy and elevated; a fold of skin forming a sort of pouch in each groin.

Mammæ to the number of six or ten. An enormous cæcum, with a spiral lamina which runs its whole length.

The infra-orbitar cavity is cribriform in the skeleton.

Habit. Nocturnal, timid, exclusively phytivorous.

Inhabit both continents under all latitudes.

\section{Species.}

1. Lepus americanus, Erxleb. Gmel. Schoepf. Naturf. 20. p. 20.

Lepus hudsonius, Pall. Glir. part 1. p. 30. Bodd. American Rabbit.

Char. Essent. Colour, a grayish-fawn, varied with brown; nucha fawn; beneath the neck and belly white; ears shorter than the head, without black at the extremity; tail grayish above, and white beneath.

Dimersions. Total length one foot two inches; of the head three inches six lines; of the ears two inches three lines; of the tail two inches.

Description. Ears shorter in proportion than those of the Hare or European Rabbit; thumb of the fore feet very short and elevated; colour very similar to that of the European Rabbit, varied with blackish-brown and reddish, more red about the shoulders than elsewhere, whitish-gray about the 
breast, white under the belly, a whitish spot before the eyes, and another behind the cheeks; ears of a uniform grayish-brown; feet reddish before, with the point of the foot fawn colour; upper surface of the tail of a similar colour with the back, beneath white; fur becoming whiter during the winter, but the ears and tail remaining always of the same gray.

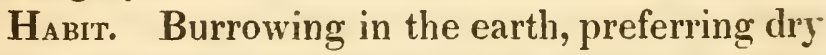
places; female bringing forth three or four times annually, from five to ten at a time; period of gestation endures about six weeks; the female will receive the embraces of the male immediately after delivery. In the domestic state the latter is apt to destroy the young.

Inhabit the whole extent of the United States.

Species.

2. Lepus glacialis, Sabine, Suppl. to captain Parry's voyage, 1819-20.

Char. Essent. Colour white; ears black at the tips, longer than the head; nails robust, broad and depressed.

Dimensions. Larger than the $\boldsymbol{L}$. variabilis, (which is two feet four inches two lines from the end of the snout to the anus,) the average weight being about eight pounds.

Description. The ear's are longer in proportion to the head than those of the common hare, ( $L$. timidus, and much longer than those of the $\mathcal{L}$. 
variabilis; the ears of the common hare are usually considered one-tenth longer than the head, those of the present species are from one-fifth to one-seventh; the fore teeth are curves of a much longer circle, and the orbits of the eye project much more than those of either of the other species; the claws are broad, depressed and strong; those of the L.timidus and variabilis being on the contrary, compressed and weak; the hind leg is shorter, in proportion to the size of the animal, than in the variabilis; the fur is exceedingly thick and woolly, of the purest white in the spring and autumn, excepting a tuft of long black hair at the tip of the ears, which is reddish-brown at base; the whiskers are also black at the base for half their length. In some of the full grown specimens killed in the height of summer, the hair of the back and sides was a grayish-brown towards the points, but the mass of fur beneath still remained white; the face and the front of the ears were a deeper gray; the fur is interspersed with long solitary hairs, which in many individuals were banded with brown and white in the middle of summer. The hares which Mr. Hearne describes in his northern voyage, as inhabiting the continent of America as high as the seventy-second degree of latitude, are stated to weigh fourteen or fifteen pounds when full grown and in good condition. The largest hare killed at Melville Island did not weigh nine pounds; were it not for this difference. 
in size, they might be supposed, from other parts of their description, to be the same species. (Sab.)

Inhabit the Arctic Circle, Greenland, the southern coast of Barrow's straits, and the north Georgian islands, where they are very abundant. They feed in ravines, near the bottom of steep clifts by the sea-side, which they ascend with great agility on being alarmed, and secure themselves amongst the loose stones near the top of the clifts. None were seen during the winter, but it does not seem. probable that they had deserted the island.

Note.-Perhaps may be referred to this species also, the Greenland hare, or Rekalek, which remains entirely white, even in summer, with black at the end of the ears; the young being whitish-gray; the female bringing forth eight young at a time. The food of this animal consists principally of the tender herbs, which grow along the brooks on the slopes of the Greenland Mountains.

\section{Species.}

3. Lepus virginianus, (Nobis) Varying hare, Warden's Descrip. of the United States, vol. v. p. 632 , in a note.

Char. Essent. Grayish-brown in summer, white in winter; the orbits of the eyes surrounded by a reddish-fawn colour at all times; ears and head of nearly equal length; tail very short. 
Dinensions. Total length from the tip of the nose, along the back to the root of the tail, sixteen inches; length of the ears four inches.

Warden states that the largest hares are eighteen inches total length, and weigh from seven to eight pounds.

Description. (Winter dress, at the commencement of spring.) General colour a snow-white, at the end of the snout intermixed with fawn; ears within naked, bordered with brown hairs intermixed with white; externally their anterior surface is reddish-brown; posterior surface white, slightly marked with dark plumbeous at tip; fur fine, soft, and long, most abundant on the breast, plumbeous at base, then reddish, then pure white; tail very short; legs longer and more slender, ears longer in proportion to those of the common American rabbit, ( $L$. americanus, nails long, slightly arched, subulate, and compressed at base, entirely covered by the hair which projects from the top of the foot; incisors above and below of nearly equal length; the inferior straight and cuneiform; the superior slightly arched, and marked by a longitudinal groove near the inner margin; whiskers, some entirely white, some black, others white with black at their base.

Haвiт. These animals never burrow, but frequent meadows, \&c. near the base of mountains, and when pursued retreat into hollow trees; they 
bring forth several times a year, three or four at a time, after a gestation of about thirty days.

The above description is taken principally from a prepared specimen in the possession of Mr. C. Bonaparte, and was killed on the Blue Mountains, in the state of Pennsylvania.

Inhabit the southern and middle states, and most probably as far north as New England.

Note.-It is most probably this species alluded to by Mr. Lewis, in his Notice of Animals discovered in the Missouri country. "A species of hare, apparently the Lepus variabilis, or varying hare, which is common in Hudson's Bay, New York, Pennsylania, Virginia, \&c." (Vid. Barton's Med. and Phys. Journal, vol. ii. part 2. page 159.) 


\section{ORDER, EDENTATA.}

Character. No incisors in either jaw. Sometimes canine and molar teeth, at other times molars only, often none whatever. Four extremities terminated by a variable number of toes, armed with large nails, never constructed like hands. The orbitar and temporal fossæ united.

Nourishment phytivorous, insectivorous, or carnivorous, according to the species.

Habit. Generally very slow in their movements; some destined to climb. trees, some to burrow in the earth, others to swim, \&c.

Inhabit South America, Africa, the Indian Archipelago, and New Holland. In North America, they are found only in a fossil state.

\section{1 st Tribe, Tardigrada.}

Char. Face short.

Canines and molars, or molars only ; claws very long and hooked.

Inhabit South America. Fossil locality, Noth and South America.

\section{Genus.}

Megatherium, Cuvier. (Foss.)

CHARACTERg,

Hental formula. - Teeth 10. $\left\{\begin{array}{l}\text { superior } 6 . \\ \text { inferior 4. }\end{array} \begin{array}{l}\text { Incisor } 2 . \\ \text { Molar } 4 \\ \text { Molisor } 0 . \\ \text { Molar } 4\end{array}\right.$ 
Molars with broad crowns, marked with transverse angular eminences.

Zygomatic arches entire, furnished at their anterior base with a very large descending apophysis as in the sloths.

Lower jaw having its posterior or angular rising: portion very broad; and its anterior or projecting portion grooved.

Nasal bones very short; upper maxillary bones very much elongated forwards; seven cervical vertebræ, sixteen dorsal, and three lumbar. Tail very short, if there existed any?

Clavicles perfect.

Posterior extremities much more developed than the anterior. Five toes to each foot, three only of which are furnished with very powerful hooked claws, the others rudimentary.

Species.

\section{Megatherium cuvieri.}

Megathère, Cuvier, Magas. Encycl. an 4. Descrip. d'un squelette conservè dans le Mus. de Madrid. Traduct. de Garriga. Cuv. Ann. du Mus. tom. v. page 376. pl. 24 et. 25. Ejusd. Recherch. sur les Ossemens Fossiles, 1 edit. tom. 4. Animal du Paraguay. Megatherium, S. L. Mitchill, Ann. of the Lyceum of Nat. Hist. New York, vol. i. p. 58. W. Cooper, ejusd. vol. i. p. 114.

Char. Essent. Crowns of the molar teeth marked with transverse angular eminences. 
Dimensions. Total length of the body twelve feet; height at the withers five feet three inches.

Description. The characteristic traits are those peculiar to the genus.

Habit (presumed.) The immense thickness of the branches of the lower jaw, which even surpasses that of the elephant, would appear to indicate that this animal was not restricted to eating leaves, but like the elephant and rhinoceros, comminuted the branches of trees also. Its compact teeth, transversely grooved, are instruments very proper for this purpose.

Locality. The skeleton, nearly entire, of the Paraguay animal, has been found one hundred feet beneath the sandy diluvial, in the neighbourhood of the river Luxan, three leagues south-west of Buenos Ayres; two other skeletons less complete have been sent to Spain, one from Paraguay, the other from Lima. In North America the remains of this animal have been recently discovered in the marshes of Skidaway island, on the sea-coast of Georgia.

\section{Genus.}

Megalonix, Jefferson.

Char. Molars cylindrical, simple, hollow in the centre of their crowns, with the margins of the enamel projecting.

\section{Species.}

1. Megalonix jeffersonii. Megatherium jeffersonii, Desm. Mammalogie, p. 336 . 
Megalonix, Jefferson, 'Trans. of the Amer. Philos. Soc. No. 30. p. 246 . Cuvier, Recherche sur les Ossem. Foss. 1 edit. tom. 4. Ejusd. Ann. du Mus. tom. v. p. 358. pl. 23.

Characters of the species are those peculiar to the genus.

Dimensions. One-third smaller than the preceding; about the size of an ox.

Description. The remains of this animal present the unguicular phalanges very voluminous, and very much resembling those of the large toes of the Megatherium of Cuvier, and consequently like those of the Sloths and Ant-eaters; the radius and ulna are very similar to the corresponding bones of the same animal, differing only slightly in the form and dimensions of the various articular surfaces and apophyses; the fore feet have five toes, of which the thumb and little finger are rudimentary, and the others armed with robust claws; the teeth of this species more nearly resemble those of the Sloth than any other known animal.*

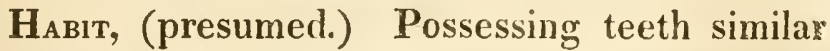
to the Sloths; like them the Megalonyx was most probably herbivorous, their feet being so nearly alike, it is presumed that their motions were also similar to these animals.

* With the exception of the teeth of the Chlainyphorus truncatus. Vid. Ann. of the Lyceum of Nat. Hist. Few Jork, No viii. p. 235 . pl. xxi. 1825. 
Locality. The bones of the Megalonyx were found for the first time in 1796, at the depth of two or three feet, in Green-briar county, western part of the state of Virginia.

\section{Order PaChydermata.}

Char. Sometimes three sorts of teeth, sometimes two only.

Four extremities solely destined for progression, the toes of which are furnished with nails or hoofs, varying in number.

No clavicles. Organs of digestion not con. structed for rumination; stomach simple, membranous, or more or less divided by membranous septæ; animals of this class are generally herbivo. rous, some of them, nevertheless, can occasionally subsist on animal food.

HabiT. Varying with the organization.

Inhabit all warm and temperate countries of the earth.

\section{Family PROBOSCIDEA.}

Char. Superior incisors in form of tusks; mo. lars compound, few in number. 
Five toes to each foot; nose prolonged into a great trunk, cylindrical, and moveable in every direction, and terminated by an organ of touch and prehension; form massive; skin very thick; nourishment purely vegetable.

Inhabit the warm countries of the old world. (Living species.)

\section{Genus.}

Elephas, Linn. Briss. Erxleb. Bodd. Cuv. Geoff. Illig.

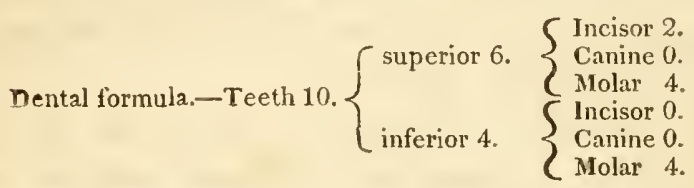

Superior incisors in form of tusks, often very large, cylindrical, curved downwards, and elevated at their points, formed of a close osseous texture, and offering lines more hard and compact, convergent, and intersecting so as to form very regular, curvilinear lozengers; these tusks are besides surrounded by a very light layer of enamel, properly so called.

Molars composed of vertical and transverse laminæ; these laminæ are each formed of an osseous substance, enveloped in enamel, and all united together by a solid inorganic substance or cement; the molars proceed obliquely forwards 
from the bottom of the jaw; body very large, rather short, and situated high upon the legs: head very large; neck very short; proboscis very much elongated, moveable in all directions, enclosing the two nasal tubes, and terminated by a moveable appendage which performs the function of a finger; cyes very small, lateral; external ears flat and very large, lateral; tongue fleshy, smooth. and very thick; legs very long, thick, and terminated by five toes, which are only apparent through the hoof placed at the base of the foot. and of which one or two are wanting in the hind foot; tail moderate, terminated by a tuft of coarse hairs; two pectoral mamma; skin very thick, rugous, rather loose, naked in the living, hairy in the fossil species.

Frontal and maxillary sinuses very large, and extending over the greatest portion of the cranium; openings of the anterior nares very high ; proper bones of the nose small, triangular, and thick; inferior jaw pointed before, with its sym. physis grooved; articular condyles of the large bones of the extremities, disposed in a vertical line; head of the femur in the axis of the bone; acetabulum situate rather beneath the pelvis; stomach simple; intestines voluminous; cæcum enormous.

Liver composed of two lobes; no gall bladder.

Навіт. Powerful, robust, endowed with much intelligence, using their trunk with great address. 
which is at the same time the seat of smell and touch. 'They live in troops, at the head of which is an old male or female; they feed on leaves, roots, and fruits; all food and drink passes from the trunk to the mouth, except during infancy; the young sucking the mother, like other animals, with the mouth; the female is capable of receiving the male at the age of fifteen years; gestation lasts twenty-two or twenty-three months.

The young, which is mostly single, sucks for two years; loosing the milk tusk in about thirteen months, those which succeed grow during the remainder of life; they begin to cut their milk molars at the end of six weeks, and these are complete in three months; the second molars have appeared at the end of two years; the third force these out at the sixth year; the fourth push forwards the third at the ninth year; the number of laminx in the tooth increases in the order in which they appear; the number in each tooth varies from four to twenty-three.

It is probable that the life of these animals endures for two hundred years, they having been kept in a domestic state for one hundred and twenty or one hundred and thirty years. 'They are fond of music.

Their voice, which is commonly a weak whistle, becomes terrible when they are irritated.

When domesticated, these animals consume 
about two hundred pounds of food daily; they sleep during the night in a recumbent posture.

Species. None living on the continent of America.

Fossil Elephants.

\section{Species.}

1. Elephas primogenius, Blumenbach. Mammoth of the Russians, Cuv. Mèm. de l'Inst. Part. Phys. tom. 2. Ejusd. Ossem. Foss. 2. edit. t. 1. p. 75. pl. 2. Le squelette.

Char. Essent. Head elongated; forehead concave; alveoles for the tusks, very large, marked by ribbands of enamel parallel to each other and very close; inferior jaw obtuse before.

Druensions. Very little larger than the Indian elephant; form rather more contracted.

Descriptron. M. Cuvier, by a minute examination of all the bones which have been collected of this species, which are very numerous, is convinced that they present remarkable differences from those of the two living species; the fossil clephant resembles the Indian more than the African species, in the form of the cranium, but it diflers particularly. 1st, In the form of its molar teeth, which are much larger, and possess parallel borders; as well as in the crowns which have a much greater number of parallel plates of 
enamel. $2 \mathrm{~d}$, In the more contracted form of the inferior jaw, the symphysis of which is rounded, in place of being pointed; finally by the extreme length of the alveoles for the tusks, which must have modified in a singular manner the form and structure of the trunk. The tusks are very long. more or less spirally arched and directed outwards.

In the Petersburg Museum, there is an individual preserved, with portions of its skin and flesh. discovered a few years past by Mr. Adam, enveloped in ice, in Siberia.

When first noticed, it was nearly in a perfect. state of preservation, and was covered with two sorts of hair, viz. a reddish wool, thick and bushy, and a thick and black main on the neck and along the back.

Localiry. In Europe, these remains abound in northern countries, also in France, Italy and Germany. In America they are also scattered over a great range of country, but are more frequently met with in the States of Kentucky, North and South Carolina, Pennsylvania, \&c. From observations lately published in the Phil. Jour. Acad. Nat. Sciences, (vid. vol. iii. p. 65.) there would appear to have existed two distinct species in the United States.

These remains are most generally discorered in the diluvial deposites which fill vallies, or on the borders of rivers; in our own country they are 
mixed with the remains of the $O x$, Deer, and Mastodon; in Europe, also with the Rhinoceros.

Mr. Cuvier is of opinion that these animals must have lived and died in those countries and situa. tions in which their bones are discovered at the present day, and that all the individuals then existing perished, simultaneously and suddenly, from some great catastrophe, concerning the nature of which we are unacquainted. The entire body with its flesh, discovered in Siberia, proves that the animal was seized by the ice immediately after its death, and the thick coat of wool and hair with which it was covered would well adapt it for a residence in cold climates. The isolated bones, which are met with every where, are often observed to have marine animals attached to them, which establishes, in an incontestible manner, that since their dispersion they have been covered by the ocean, under which they have been buried a considerable time.

\section{Genus.}

Mastodon, Cuvier, (fossil.)

CHARACTERS.

Dental formula. -Teeth 10. $\begin{cases}\text { superior 6. } & \left\{\begin{array}{l}\text { Incisor } 2 . \\ \text { Canine 0. } \\ \text { Molar 4. }\end{array}\right. \\ \text { inferior 4. } & \left\{\begin{array}{l}\text { Incisor 0. } \\ \text { Canine 0. } \\ \text { Molar 4. }\end{array}\right.\end{cases}$

Incisors in form of tusks, a transverse section of which presents in the interior a homogeneous, 
dense structure, composed of concentric laminæ, which vary from two to four-tenths of an inch in thickness, and do not display those curvilinear lozenges so conspicuous in the tusk of the Elephant.

Note. This difference of structure noticed in the tusks of the Mastodon and Elephant, first observed by Cuvier, is overlooked by Desmarest, who attributes to each a similarity of structure; the fact, as above stated, we have repeatedly verified by observation.

Molars rectangular, formed simply of an osseous substance, surrounded with enamel, without cement or cortical matter, having their crowns elevated into large points, disposed in pairs, varying in number, according to the age and position of the tooth, from six to ten; these molars advance in the jaws in proportion as they become developed; their crowns displaying, when half worn, as many lozenges of enamel as there were originally points to the tooth; very old animals have only one molar on either side of each jaw.

The Os incisivum is prolonged and pierced with large alveoles for the tusks.

Inferior jaw terminated before by a point, in which is a canal.

Neck very short; extremities very long, and lerminated by five toes; tail moderately long; seventeen pairs of ribs, of which six are true. 


\section{Species.}

1. Mastodon giganteum, Cuvier, Recherches sur les Ossemens Fossiles, nouv. edit. tom. 1. p. 206. pl. 1 and 7. Peale's account of the skeleton of the Mammoth, 4to. Nammolh of the Americans. Father of Buffaloes of the North American Indians. Animal of Olio of the French.

Char. Essent. Molars rather broad in proportion to their length, their crowns displaying, when half worn, lozenges of enamel.

Dinensions. Height at the withers from ten to eleven feet; length from the end of the snout to the posterior part of the pelvis, from fifteen to sixteen feet and a half.

This difference arises from the inaccurate manner in which the skeleton in the Philadelphia Museum is articulated; though this is the most perfect specimen hitherto discovered, the upper part of the head is destroyed, and the tusks are placed in an inverted position; the tusks are nine feet in length; each molar weighs twelve pounds.

Description. In the general structure of the skeleton, there is considerable analogy to the fossil Elephant; it is proportionably longer than the Elephant, and from which it differs in the structure of the tusks and molar teeth, as noticed above.

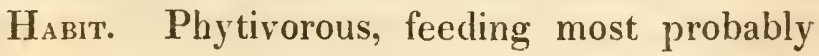
chiefly on leaves, limbs and tops of young trees, \&c.

Locality. The remains of this animal, hitherto 
discovered only in North America, are in some instances better preserved than most other fossils, though this depends, in a great measure, on the nature of the soil from whence they are disinterred. They are most frequently met with beneath the surface of dried marshes, situated in the valleys of the largest rivers, as the Mississippi, Missouri, Hudson, Ohio, \&c. 'They not unfrequently occur' in the State of New York and New Jersey in diluvial deposites. The most perfect and largest specimen of a molar tooth we have yet seen, was fished up from the ocean at Long Branch, on the shore of New Jersey; now in the cabinet of Dr. Morton.

The remains of this extinct species have not been found south of lat. 31 , or north of 43 , near to lake Erie. The colour of the enamel is found to vary with the soil in which they occur.

Besides the present, five other species of this genus have been described by $\mathbf{M}$. Cuvier, from South America and Europe.

Among a collection of fossils, such as the Elk, Buffaloe, \&c. lately presented by Maj. Long, from Big-bone-lick, in the state of Kentucky, is the molar tooth of a species of Mastodon somewhat different from the many others we have examined, and which approaches in some respects, the Mastodon tapiroides, of Cuvier; though the specimen is not sufficiently perfect to enable us to decide with certainty. 


\section{Species.}

2. Mastodon angustidens, the narrow tooth Mastodon, Cuvier, Ann. Mus. tom. 8. p. 405. Recherches, sur les Ossem. Foss. 2 edit. tom. 1. p. 250. pl. 1. fig. 1, 2, 3, 7. pl. 2. fig. 6, 7, 8, 9, 10, 13. pl. 3. fig. 1, 2, 3, 4, 5, 8. pl. 4. fig. 1, 2, 3, 6, 7. Animal de Simore, Réaum. Mem. de l'Acad. des Sc. Annèe. 1715, p. 174.

Char. Essent. Molars narrow and elongated, their crowns presenting from detrition, disks of enamel, in form of trefoils.

Dimenșions. One third less than the Mastodon giganteum, and less elevated on the legs.

Description. The cones of the crowns of the molars, marked by grooves more or less deep, sometimes terminating in several points, sometimes accompanied by other smaller cones on their sides or intervals, from whence it results that mastication produces upon this crown, at first, small circles of isolated enamel, and afterwards trefoils or figures of three lobes, but never lozenges; the first molar, small, with four tubercles, and appearing to project perpendicularly; the second with six tubercles, projecting from behind forwards, as likewise the third, which has ten tubercles; all these teeth do not appear to have existed at the same time in the mouth, the first becoming developed and used, then the second, then the third, which appears alone to oc- 
cupy the alveolar border, and which is sometimes truncated to such a degree, as to represent only a cuneiform substance of ivory, surrounded by festooned enamel.

Locality. The teeth of this animal have been found, first at Simore (Gers) in a sandy rock or in sand; they are coloured with iron, and become blue when burned. They are known by the name of Western turquoises. They are still met with at Sorde, near to Dax, (Landes) in diluvial stratx. At Trèvoux, (Cote-d'or) in sand; at Santa Fe dé Bogota, at a place called the "Field of Giants," at an elevation of one thousand three hundred toises above the level of the sea. On Mount Follonico, near to Mount Pulciano, in the Val d'Arno, in Piemont; and lastly, the specimen before us, was found in Club-foot canal, connecting Newbern to Beaufort, in the state of North Carolina.

This tooth is in the cabinet of Mr. Wagner, of Philadelphia.

An immense number of fossil bones were disinterred many years ago at Big-bone-lick, by Dr. Goforth, for an account of which, Vid. "Cramer's Navigator," eighth edition, 1814, append. p. 260. Among these bones the author notices the " paw of an unknown animal of a size sufficient to fill a flour barrel; it had four claws, and when the bones were regularly placed together, measured from the os calcis to the end of either mid. dle claw, five feet two inches. 
"The bones of this paw were similar to those of a bear's foot. Where I found these bones, I found large quantities of bear's bones at the same time, and had an opportunity of comparing and arranging the bones together, and the similarity was striking in every particular except the size.

"The vertebræ of the back and neck when arrayed in order with the os sacrum and os coccygis, measured nearly fifty feet, allowing for cartilages; though I am not confident the bones all belonged to one animal. I had some thigh bones of the incognita of a monstrous size when compared with my other bones, which I much regret I neither weighed nor measured.

"These bones were all obtained at Big-bonelick, in the state of Kentucky, three miles from the Ohio river. This Lick was formerly a saltmarsh; we generally dug through several layers of small bones in a stiff blue clay, such as deer, elk, buffaloe, and bear's bones, in great numbers, many of them much broken; below which was a stratum of gravel and salt water, in which we found the larger bones, some nearly eleven feet deep in the ground, though others were found on the surface. These bones were never regularly connected together, but lay scattered in various directions."

It will be readily perceived that in the above account of the bones of the incognita, the Doctor has confounded the vertebre and claws of several 
individuals; his descriptions of the same are too loose and inaccurate to enable us to form any positive conclusions on the subject, but from other circumstances connected with their history, we have reason to believe that they belonged to the Megatherium or Megalonix; be this as it may, the subject is replete with interest, and highly deserving of further investigation; any information concerning them, must be sought for from some European naturalist, as all these bones were taken to England, by Mr. Thomas Ash, (author of "Travels in America," published in London in 1819, he having basely stolen the same from Dr. Goforth."

* The villany and theft of this Thomas Ash, cannot be too publicly and generally known, and we subjoin an extract from the work above quoted, detailing the particulars of this transaction.

"Dr. Goforth, had for several years been engaged in collecting the Mammoth aud other enormous bones, at the Bigbone-lick, at a great expense and labour. In the year 1804 or 1805 , he conveyed about five tons of these bones to Pittsburg, with a view of transporting them to Philadelphia. The bones, however, remained in Piltsburg for some time. Mr. Ash had passed through Pittsburg, and descended to Cincinnati. There learning that Dr. Goforth had a very valuable collection of big bones, he soon ingratiated himself into the Doctor's good graces, and entered into written articles to become his agent for the sale of the bones; New Orleans being fixed upon as the market. Accordingly, Mr. Ash returned to Pittsburgh in 1806 or 1807 , with an order for the bones, which were in the posscssion of Dr. Richardson, who delivered them to Mr. Ash, (or 
2nd Family. PACHYDERMATA, properly so called.

Char. 'Three sorts of teeth, in the greatest number, at least two in the remainder; feet terminated by four toes at most, and two at least, excepting in the Pecari, in which one lateral toe is not developed.

\section{Genus.}

Sus, Linn. Briss. Erxleb. Cuv. Geoff. Illig.

CHARtcters.

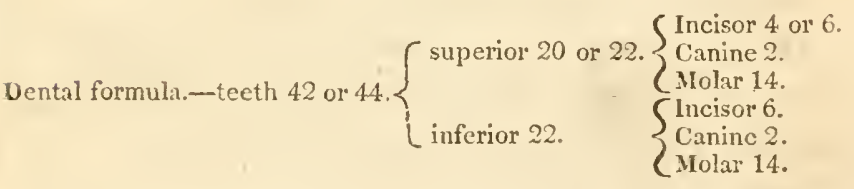

Inferior incisors directed obliquely forwards, with cutting edges; superior incisors conical.

Canines strong, projecting from the mouth, and curving upwards, sometimes very long, destitute of proper roots, and growing during life.

Molars simple, the anterior small and narrow, the last four furnished with blunt tubercles, dis-

Arvil, the name he then went by.) The bones were boated by Mr. Ash to New Orleans, where he made a feint to sell them, and was offered seven thousand dollars for them. He observed that the sum was not one tenth their value, and from New Orleans he shipped them to London." (Vid. append. p. 259.) 
posed in pairs; nose elongated, cartilaginous, truncated at the extremity, and furnished with a small bone.

Eyes small; pupil round.

Ears considerably developed and pointed.

All the feet having four toes, two large intermediate only resting on the soil, and two more small, elevated and placed a little backwards, each furnished with small triangular hoofs.

Tail moderately long.

Twelve mammæ.

Body covered with a thick skin, clothed with stiff and long hairs called bristles.

Stomach membranous and simple.

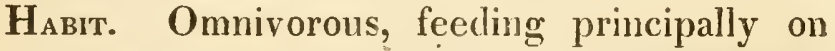
roots and fruits, voracious to excess, delighting to wallow in soft, muddy, or marshy places.

Inhabit the ancient continent.

\section{Species.}

1. Sus scrofa, (Encycl. pl. 37 and 38.) Sus ferus, Plin. Sus aper, Briss. Sus scrofa, Var. Aper, Linn. Le Sanglier, Buff. Vulgarly "the Hog."

Char. Essent. 'Tusks robust, triangular, directed laterally, moderately elongated; no protuberance beneath the eyes.

Inhabit the temperate climates of Europe and Asia.

Not indigenous to North America, but many of the domestic varieties exist, some of which have 
been allowed to run wild, and propagate in the western forests; these have in part regained their uative instinct and ferocity, their ears becoming erect in some instances; when attacked by Bears, Panthers, or other enemies, they unite together for common safety, forming themselves into a solid triangle, the strongest males presenting their front to the enemy, the young being in the middle. They feed on acorns, nuts, fruits, roots, \&c.

\section{Genus.}

Pecari or Dicotyles, Cuv. Sus, Linn. Erxleb. Bodd. Schreb. Geoff. Illig.

CHARACTERS.

Dental formula.-Teeth $38 .\left\{\begin{array}{l}\text { superior 18. }\left\{\begin{array}{l}\text { Incisor } 4 . \\ \text { Canine } 2 . \\ \text { Molar } 12 . \\ \text { inferior 20. }\end{array}\right. \\ \begin{array}{l}\text { Incisor 6. } \\ \text { Canine 2. } \\ \text { Molar 12. }\end{array}\end{array}\right.$

Superior incisors vertical, inferior projecting forwards.

Canines small, triangular, very sharp, nearly similar in their position to those of the Boar, but not projecting out of the mouth.

Molars with tubercular crowns; tubercles rounded, and irregularly disposed.

Head long and pointed; snout straight, terminated by a cartilage.

Ears moderately long, pointed; eyes small, pupil round.

Fore feet with four toes, the two intermediate. 
the largest, the two lateral are much shorter, and do not rest on the ground; hind feet with three toes, two long like the anterior, and one shorter internally ; the external altogether wanting.

A gland situated upon the lumbar region, excreting through a valvular opening an extremely fetid, oily humour.

Tail replaced by a tubercle; body covered with strolig, stifl' bristles.

The metatarsal and metacarpal bones of the two large toes of all the feet united together to form a canon bone like that of ruminants.

Stomach divided into many pouches by membranous septr.

Habit. Analogous to that of the wild Boar.

Species.

1. Dicotyles torquatus, Fred. Cur. Dict. des sciences Nat. t. 9. p. 518.

Pecari, Buff. Hist. Nat. t. 10. pl. 3.

Pecari ou tajassou, Daub. Descrip. Anat,

Tayfelou, d'Azara, Essai sur l'Hist. Nat. des Quadr. du Parag. t. 1. p. 31. Patira de la Guyane, according to Laborde.

Sus tajassu, Linn. Erxleb. Bodd.

Pecari, F. Cur. Mamm. Lithogr. (Encycl. pl. 39. fig. 2.)

Char. Essent. Hairs annulated by dirty-white and black; a large whitish band, descending obliquely from each shoulder to the sides of the neck. 
Dinersions. Total length two feet seven inches; height before, one foot six inches six lines; height behind, one foot seven inches; length of the head, two inches four lines.

Description. General aspect of the common log-ear's straight; body rather contracted, covered with very stiff bristles, alternately annulated throughout their length with dirty-white and black, from whence results the general complexion of deep gray; a whitish band, two inches broad, departing from the top of the shoulder on each side runs towards the lower part of the neck; cheeks of a less deep gray than the rest of the body; hairs of the head short, and very sparse about the eyes and toes; skin, the colour of livid flesh, the humour secreted by the dorsal gland diffusing a smell somewhat similar to that of garlic.

The young animal of a clear brownish-fawn colour, with a blackish dorsal line.

Навіт. In a savage state, the Pecari live in small families, affecting generally elevated situations; when attacked by the Panther, they fight courageously, and never desert each other, so that the Panther is occasionally found dead on the field, surrounded by half a dozen of his slain enemies. In a domestic state they attach themselves to man, and are fond of his caresses.

Inhabit South America, in those countries bordering on the Atlantic, and extend into the United States; are common on Red River, where they 
were noticed by Mr. Nuttall, who also states that a skull of this animal was found in the Saltpetre cave of Kentucky. Vid. "Travels in Arkansa Territory," p. 155.*

\section{Genus.}

Tapirus, Briss. Schreb. Cuv. Geoff. Tapir, Gmel. Illig.

Hippopotamus, Linn. Hydrocharus, Erxleb. Storr.

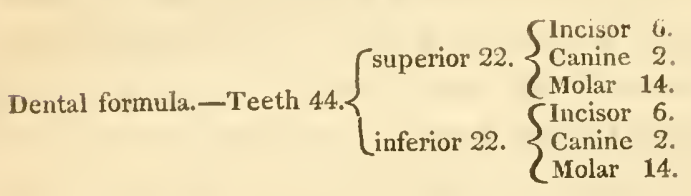

* Mr. Nuttall probably alludes to the notice by Dr. Samuel Brown, Professor of Practice in the Transylvania University, of a skull found in the Saltpetre caves of Kentucky. (Vid. Barton's Med. and Phys. Journal, vol. ii. part 2. p. 158.) 'This skull certainly belonged to the recent Pecari, and is at present in the cabinet of the American Philosophical Society.

"The very respectable and ingenious Dr. Samuel Brown, informs the editor, that there has recently been discovered in one of the nitrous caves which are so common in Kentucky, the cranium of a large species of Sus, or $\mathrm{Hog}$, in a state of excellent preservation. With the exception of the Mexican Hog or Peccary, no species of the genus has been discovered native within the limits of North America. The Peccary itself is said to be a pretty common animal in the 'Trans-Mississippi part of the United States." 
Incisors in both jaws opposing after the manner of forceps; the intermediate short, cuneiform, truncated, the lateral nearly in form of canine.

Canines of moderate size, conical, crossing like those of carnivorous animals, an intermediate space between them and the molars.

Molars square, having the crowns marked with two transverse eminences.

Nose prolonged into a moveable trunk, rather short, and not prehensile like that of the elephant.

Eyes small; ears long and moveable.

Anterior extremities provided with four toes, with short and rounded hoofs; the posterior with three toes only; tail very short.

Two inguinal mammæ, those of the male placed on the sheath; skin hard, covered with hair.

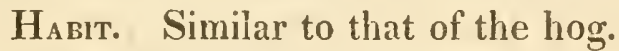

Inhabit South America, Mexico, the peninsula of Malacca, the isle of Sumatra.

* The bones of a fossil Tapir, of the size of the largest elephants, have been discovered in several localities on the continent of Europe, and are accurately described by M. G. Cuvier, (Recherches sur les Ossem. Foss. 1 edit. tom. 2. chap. 8.)

Hitherto fossil bones of this animal have not been discovered on the continent of America, but among other fossils lately received from the state of Kentucky, (and for which we owe many obligations to Major Long, a gentleman whosc 
name has been so frequently connected with the most important discoveries in natural science,) is a molar tooth, which, on being compared with the teeth of the Tapirs, both living and fossil, (as well as with those of the Manatus and Kangaroo, with which alone the Tapir could be confounded in this particular,) is recognized as belonging to a very small extinct species of this genus.

Tapirus mastodontoides, (Nobis.)

Character. Less than one third the size of the Tapirus giganteus, or nearly the size of the living Tapir; crowns of the molars, when worn by detrition, presenting disks resembling those on the teeth of the Mastodon giganteus.

Dinensions. (Of the molar tooth.) Length of the crown one inch four tenths; breadth one inch; length of the body projecting above the alveole seven tenths; length of the roots one inch two tenths.

Description. Molar tooth of the upper jaw, left side; crown nearly quadrangular, traversed by two eminences, running obliquely from without, inwards and backwards, united at their external border by a crest of enamel, as in the teeth of the recent Tapir; these eminences are about one half worn, and present disks of an irregular form unlike the other fossil, or the recent Tapirs, but resembling the disks of a half worn tooth of the Mastodon giganteus. On the posterior part of the body of the tooth, near the surface of the 
crown, projects a sort of spur of enamel, lying in the direction of the transverse oblique eminences. Two strong roots, one anterior, the other posterior, rather flattened in their antero-posterior direction, and slightly divergent at their distal portion, very analogous to those of the small fossil Tapir of Cuv. (Anim. Foss. vol. ii. pl. 4.) The whole tooth is completely petrified to its centre, very brittle and tinged with iron.

Remarks. In size and form, this tooth bears considerable analogy to the teeth of the small fossil Tapir of Cuvier, but differs, 1st, in the greater obliquity of the transverse eminences;) (this is less important, as the teeth described by Mr. Cuvier belonged to the lower jaw.) 2nd, In the form of the disks occasioned by detrition it differs from both the fossil and recent Tapirs. The transverse eminences or crests of enamel, are straight in the living species, very oblique in this fossil, the disk forming a simple triangle in the former. 


\section{Order PECORA.}

Ruminating Animals:

Character. Inferior incisors only, ${ }^{*}$ and moss trequently eight in number.

Canines sometimes wanting; crowns of the molars formed of two double crossings of enamel. disposed in pairs, and in inverse directions in the two jaws, the convexity being turned outward in the lower jaw, and inward in the upper; four extremities solely destined for progression; two equal toes furnished with hoofs; a single metacarpal or metatarsal bone for the two toes of each foot.

No clavicles; organs of digestion disposed for rumination; four stomachs, 1. the ventriculus, or paunch; 2. reticulum, bonnet, or honey-comb bag; 3. omasum, or many-plies, which is the smallest: 4. obomasum, ventriculus intestinalis, Caillette, or Red, which has a pyriform appearance, and is next in size to the paunch. Intestines very much developed; mammæ, to the number of two or four always inguinal. Often with horns, which vary in structure; nourishment, vegetable substances.

Habir. Peaceable; living in forests, where they

* The Camels form the only exception; these having two lateral teeth implanted in the os incisivum of each side; but they have the form and use of canines. 
often unite in troops more or less numerous; first swallowing a large quantity of food'without chewing, which rests for a time in the first stomach, from whence it is forced into the mouth during repose, to undergo the process of chewing, (their jaws acting laterally,) and then to pass into the second stomach.

Inhabit nearly the whole globe. None have as yet been discovered in New Holland.

Second division; ruminants having either hollow horns, or osseous and deciduous, at least in the male sex.

\section{Tribe.}

Osseous horns, ordinarily branched, deciduous, reproduced every year larger than the year preceding, always existing on the head of males, and occasionally on the head of females.

\section{Genus.}

Cervus, Briss. Linn. Erxleb. Bodd. Cuv. Illig.

Characters.

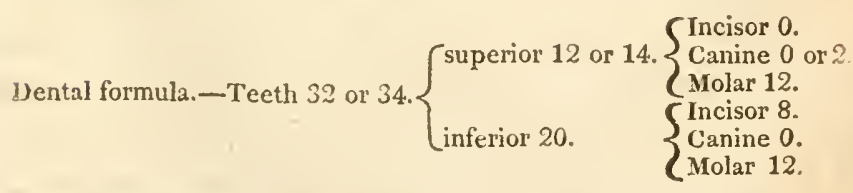

Superior canine in the males of several species, commonly compressed, and curved backwards like those of the Musk Deer. 
Head long, terminated generally by a muzzle: eyes large, pupil elongated transversely; often cribriform depressions in the bone beneath the inner canthus of the eye.

Eyes large, simple and pointed.

Tongue smooth.

Horns more or less developed, according to the species and age of the individual; at first cartilaginous and clothed with a tender skin, hairy and sensible, afterwards naked and rugous, being placed on two tuberosities of the frontal bone, and composed of a principal trunk, of branches variously directed, of enlarged and flattened parts, or knobs, which surround the bases of the stocks. and which are formed of irregular grains.

Body slender; legs fine and nervous; hairs generally dry and friable, presenting colours which are nearly similarly disposed in all the species; young individuals having often a series of white spots on a fawn base.

Four inguinal mammæ; testicles enclosed in a scrotum, and visible externally; no gall bladder.

Habit. Peaceable, and entirely herbivorous, rather intelligent, living either in troops, or isolated and in pairs, inhabiting large forests or plains; bringing forth one or two young at a birth in spring, in temperate countries, and in all other seasons in warm climates; because, in the first instance, the rut takes place in the fall; in the 
second instance, these animals are always ready to copulate at all seasons.

Inhabit both continents, and all latitudes.

Species.

1. Cervus alces, Linn. Erxleb. Alces, achlis, Plin. Aldr. Alces, Gesn. Johnst. Elant, Perrault, Hist. des Anim. 1. tab. 25. Original, Charlevoix. Nouv. Fr. 3. p. 126. Moose Deer, Dudley, Phil. Trans. No. 368. p. 155. Dale, Phil. Trans. No. 444. Warden, Descr. des Etats Unis, vol. v. p. 636. Elan, Buff. Hist. Nat. tom. \% pl. 80. Elk, Shaw, Gen. Zool. vol. ii. part 2. pl. 174 et 175 . Cervus alce, Bodd. (Encycl. pl. 57. fig. 2.)

Moose Deer.

Char. Essent. Horns consisting of a simple and very large flattened expansion, (empaumure) furnished with numerous prongs on its external border, with a large, isolated branch on the trunk or principal stock; no muzzle, (or naked part at the extremity of the nose;) snout swollen and cartilaginous; no canines in the males; tail excessively short.

Dimensions. Total length, from the tip of the nose to the base of the tail, six feet ten inches; height before, five feet two inches six lines; height behind, five feet four inches ten lines; length of the head, one foot eleven inches; of the ears, ten inches; of the horns, three feet one inch ; breadth between the two horns at their summit, three feet 
ten inches; length of the neck, one foot six inches; of the tail, one inch six lines; of the fore leg from the elbow to the wrist, one foot five inches; of the metacarpal bone, ten inches; from the wrist to the ground, one foot seven inches; length of the hind leg, from the knee to the os calcis, one foot seven inches; of the metatarsal bone, one foot; from the os calcis to the earth, one foot ten inches; (horns of the male weighing sometimes sixty pounds.)

Description. Head long, narrow before the eyes, enlarged towards the snout, which has much analogy to that of the horse; facial line straight the greater part of its length, and curved above the mouth; upper lip exceedingly developed, and very thick; no muzzle; nostrils, a lateral slit, more open anteriorly than behind; lacrymal pits small; eyes very small, and approaching the base of the horns; the latter are at a very little distance from the ears, which are very long; horns of the male during the first year, resemble those of a stag two years old, then divided during the third and fourth year, and at the fifth year a vast triangular expansion, furnished with from fifteen to twenty-eight points or prongs on its outer border, supported by a peduncle, short and thick, which is itself provided with a large aistinct prong directed forwards; female without horns; neck short; a tuft of long hair, like a beard, beneath the throat in hoth sexes, and a protuberance in the same place 
in the male; a very marked projection on the withers; back very straight from this point to the tail, which is excessively short; legs very long and thin; metatarsal bone very long in proportion to the metacarpal ; feet very long, and placed obliquely upon the soil; hairs coarse and prismatic, very friable, those upon the nucha and withers longer than on other parts, and forming a true mane; general colour fawn-brown on the top of the head, the back and the rump; of a deeper brown beneath the lower jaw and neck, on the shoulders, and arms as far as the wrist, upon the flanks, the thighs, and the top of the hind legs; of much more obscure brown before the anterior legs, above the wrist, and on the anterior portion of the hind feet; ears grayish-brown externally, of a whitish-gray within; the under part of the tail whitish; the young animal of a reddish-brown colour, without spots.

Habit. The moose live in small troops, in swampy places. 'Their gait, which is commonly a trot, is much less active than that of other deer. They feed on the buds of trees and on herbs. When they attempt to eat from the ground, they are obliged, from the shortness of their neck, either to kneel, or to separate their fore-legs. The rutting season commences with them about the end of August, and continues during the montil of September. The females bring forth from the middle of May to the middle of June; the first 
time they produce only one young, afterwards two, rarely three. The old moose loose their horns in January and February, and the young in April and May. The first have their new horns by the end of June, and the others in the month of August. Duration of life, fifteen or twenty years.

Country. The Moose Deer, called Elk, Elg, Elg, Los, Loos, \&c. by the northern inhabitants of the ancient continent, ranges in Europe from the fifty-third to the sixty-third degree of latitude. through part of Prussia, Poland, Sweden, Finland. Russia, and particularly in Livonia, and in Jugrie. In Asia it descends lower, from the forty-fifth to the fifty-first degree of latitude, particularly in Tartary.

In America, where it is named Monsoll by the Algonquins, Moose or Moose deer, by the English, and Original, by the French, it is met with in the more northern parts of the United States, and beyond the Great Lakes.

\section{Species.}

2. Cervus tarandus, Linn. Erxleb. Bodd. Tarandus, Plin. Aldr. Tapavdos, Elian. Rangifer, Gesn. Aldr. Cervus mirabilis, Cervus palmatus, Johns. Reinthier, Gesn. Caribou, Charlev. nouv. tom. 3. p. 192. Cervus groenlandicus, Briss. Regn. Anim. p. 88. No. 4. Karibou, Ejusd. p. 91 . No. 8. Renne, Buff. Hist. Nat. tom. 12. pl. 10, 11, and 12. suppl. tom. 3. pl. 18. Bis. Jeune Renne, Fred. 
Cuv. Mamm. Lithogr. (Encycl. pl. 58. fig. 3 and 4.) Rein-deer.

Char. Essent. Horns in both sexes greatly developed, the principal trunks of which are very long, thin and compressed; antlers palmated and indented; no muzzle; no canines; tail short.

Dimensions. Total length five feet six inches; of the tail three inches; length of the head one foot two inches; of the ears three inches six lines; of the horns two feet ten inches; breadth between the horns at their summits two feet two inches; length of the neck ten inches; (size of a common deer, but having the legs thicker in proportion; also the hoofs shorter and thicker.)

Description. Head strong, moderately long; snout rather thin, like other deer, the Moose excepted; nostrils obliquic, oval, not pierced in a muzzle; lachrymal cavities; ears large; no superior canines in the male; horns in both sexes varying a little in form, but generally composed in the adult males of two very long principal stalks, compressed, cast backwards, having, 1st, near the knob (at the base,) an antler directed forwards, which is terminated by an expansion, rather broad, and bordered by recurved digitations beneath; 2nd, a second antler originating near their middle, directed upwards and forwards, and terminated also by a digitated expansion; $\cdot 3 \mathrm{~d}$, a few other simple antlers above these; and 4th. a ter. 
minal expansion, rather small, and furnished with a small number of spiculæ.

Neck very short; legs thick; hoofs rounded and very broad; the small upper hoofs strongly developed; hair of two kinds, the woolly very abundant in winter, the silky like that of the deer, very friable, longer beneath the neck than elsewhere: colour varying according to the seasons, and age of the animal; the young having the superior parts of the body brown, and the inferior red; adult of a deep brown in spring, and passing successively to grayish-brown, to grayish-white, and almost entirely white during the hottest days of summer; lower portions of the legs of a deeper colour than the upper, with a narrow white ring above the hoofs.

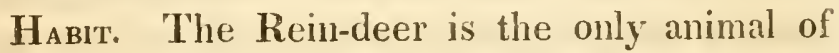
this genus which has been enslaved by man; the species, still savage in North America, has been in a great measure tamed in the northern countries of the old continent; the fawns have protuberances on the head at birth, and sprouts tro inches long at the end of fifteen days. The male adults and sterile females loose their horns in winter, and the new ones are not entirely finished until the month of August; pregnant females retain theirs until the month of May; castrated individuals often retain their horns one year longer than the others, but they change them at the end of this time. In the month of October, during the 
rutting season, the males diffuse a very disagreeable odour; they copulate only by night; gestation lasts thirty-three weeks, at the end of which time they bring forth two young in the month of May; the duration of their life is about sixteen years; they feed on herbs in summer, and moss (lichen rangiferinus) in winter, during which season they scratch the snow with their feet in order to obtain this substance; a dipterous insect of the genus $\boldsymbol{E E s}_{\boldsymbol{s}}$ trus deposits its eggs in the skin of the Rein-deer.

Country and Usages: The Laplanders collect large troops of Rein-deer, and travel with them, according to the seasons, in order to procure these animals their favourite nourishment; they castrate the greater part of the males, and harness them to sledges; the females furnish them with milk, the flesh and blood furnish them with food, their skins with clothing, their tendons with sewing threads, \&c. In America, these animals abound in the most northern legions, as Spitzbergen, Greenland, Canada, \&c. and do not pass the State of Maine towards the United States; nevertheless, they descend to lower latitudes in America than in Europe; they do not occur in Europe lower than the sixtieth degree, though, according to ancient authors, they formerly inhabited the Pyrenees; all the north-east coast of Siberia is inhabited by them; they are found savage in the Uralian mountains along the river Kema. 


\section{Species.}

3. Cervus canadensis, Briss. Cervus elaphus, Var. Canadensis, Linn. Gmel. Cerf du Canada, Perrault, Mem. sur les Anim. tom. 2. pl. 45. Cerf du Canada, Stag, Red Deer, Warden, Descrip. des Etats Unis, vol. v. p. 537. Cervus strongyloceros, Schreb. Tab. Stag of America, Catesby, Carol, app. p. 28. Cervus major, Ord. Wapiti, Barton. Mitchell, Leach, Warden, vol. v. p. 638. Elan american, Berwick, Hist. des Quad. Le wapiti, F. Cuvier, Mamm. Lithog. 21st livraison. Elk of the Americans, Lewis and Clark's Exped. up the Missouri, vol. ii. p. 167. (Encycl. pl. 38. fig. 2.)

Desmarest, in his Mammalogie, p. 443. has made distinct species of the Cervus major, or Wapiti, and the Cervas canadensis, Briss. though he has admitted the latter with doubt, on the authority of Warden and others, who have named animals without accurately describing them.

Some authors have also confounded the Cervus canadensis, with the Red deer, (C. elaphus, of Europe,) but the European species is smaller and entirely distinct.

By American naturalists, it is well known that the $\boldsymbol{C}$.major, and $\boldsymbol{C}$. canadensis, are one and the same species.

Char. Essent. Branches of the horns cylindrical, very large, with flattened expansions; having the first antler inclined in the direction of 
the facial line; a very large muzzle; lachrymal depressions; tail very short; superior canines in the male; colour fawn, more or less brown, with a large, and very pale-yellowish spot on the buttocks, comprising the tail.

Dimensions. Height at the withers four feet; height of the horns three feet; length of the first antler one foot; of the second, ten inches; length of the tail two inches.

Description. Head resembling that of the common deer ; top of the forehead, occiput, and lower jaw, of a brown colour; a black spot descends from the corner of the mouth on each side of the inferior jaw; parts encircling the eye, brown; neck of a deeper complexion than the sides of the body, of a red mixed with black, with thick and black hairs in form of a dew-lap; body above and flanks of a clear bloody-red; extremities of a deeper brown anteriorly than posteriorly; a very paleyellowish spot on the buttocks, bordered with a black line on the thighs; tail of the same colour; horns of adults branched, principal stock round; having always three antlers, without counting the subdivisions, more or less numerous, of the crown; first or largest antler somewhat inclined in the direction of the facial line; hair of middle length on the shoulders, flanks, thighs, and top of the head; shorter on the sides and legs, very long on the posterior sides of the head, and on the neck, principally beneath : a brush of yellow hairs, sur- 
rounding a corneous substance, of a narrow and elongated form, at the posterior and exterior of the hind leg; interior of the ears white, furnished with tufted hairs, externally of the colour of the surrounding parts; a naked triangular space towards the internal angle of the eye, near the lachrymal depression, which is very large.

Female differing from the male in the absence of horns, and in the less depth of colours.

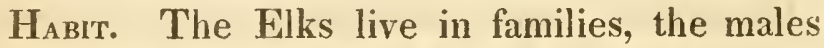
attaching themselves to the females; the members of each troop are strongly united among themselves; the rutting season commences in September; cast their horns for the most part in the month of March, the leanest Elk retain their horns the longest; the female brings forth in the month of July; when captured young, these animals are easily tamed.

Inhabit Canada, Missouri, and western States. A fine specimen in the Philadelphia Museum, thirteen years old, during nearly the whole of which period it lived in the possession of $\mathrm{Mr}$. Peale; it measures from the tip of the nose to the base of the tail, seven feet seven inches; length of the horns three feet ten inches.

\section{Species.}

1. Cerus virginianus, Virginian Deer, Pennant. Fallow-deer, Lawson, Carol. p. 123. Catesby, 
Carol. append. p. 28. Caricou femelle, Buff. t. 12. pl. 44.

Cerf de la Louisiane, ou Cerf du Virginié, G. Cuvier, Ossem. Foss. tom. iv. p. 34. Ejusd. Reg. Anim. Fred. Cuvier, Mamm. Lithogr. avec quatre figures.

(Encycl. pl. suppl. 13. fig. 2. Cerf de la Louisiane.)

Char. Essent. Horns moderate, strongly recurved forwards, having an antler high, placed at the internal face of each stalk, directed inwards, and two or three others at the posterior face directed backwards; lachrymal pits; no canines; a muzzle; colour, a cinnamon-fawn in summer, and a fine gray in winter.

Dimensions. Total length five feet five inches; height before, three feet; behind, three feet three inches; length from beneath the neck to the origin of the tail, two feet nine inches; of the tail, ten inches; the head, one foot; of the horns, following the curvatures, one foot ten inches; weight from ninety to a hundred and twenty pounds.

Descrirtion. Form light; head slender; snout pointed; lachrymal pits consisting of a slight fold of the skin; a muzzle partially developed; tail rather long and thin; horns of the fifth year consisting of two cylindrical stalks, whitish, rather smooth, separated at first rather outwards and backwards, and then recurved forcibly forwards 
and inwards; an antler, sometimes bifurcated at its point, originating at the internal face of the stalk, at some distance above the $\mathrm{knob}$, is directed inwards; others, to the number of two or three, growing from the last third of the posterior face, and directed more or less backwards, above and within; horns of the second year consisting of simple sprouts, slightly arched backwards and outwards, so that their points oppose each other; second horns very little larger, with an additional antler; third horns, or those of the fourth year, still larger, and having an additional antler; coat composed of soft and compact hairs; the colour of the young animal is of a deep fawn, with little white spots; that of adults in summer is of a beautiful fawn above; beneath the inferior jaw, within the ears, the throat, the belly, the interior of the legs, the posterior borders of the arms, and anterior of the thighs, white ; top of the snout bordering on gray; the end of the snout of a deep brown, with two small white spots on the upper lip; parts encircling the eyes brown, with a whitish circle beyond; tail thick and long, white beneath, yellowish above, for the two first thirds, and black for the remainder; buttocks white only immediately above the tail; no brown or black line on the back, nor deep oblique line on the buttocks; a fasciculus of long and hard hairs on the interior of the tibio-tarsal articulation; in winter the colour is of a rather deep grayish-brown, resulting from 
the hairs disposed in yellowish or blackish rings; above and beneath the eyes, within the ears, beneath the lower jaw, throat, belly, interior of the limbs, beneath the tail, and the corresponding portion of the buttocks, white.

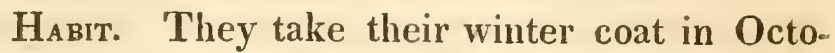
ber; their summer dress in March or April; their horns appear in September, and fall in February; they enter in rut in November or December; gestation lasts nine months; they bring forth in July or August.

Inhabit North America, enjoying the most extensive range.

According to Mr. Say, (Long's Exped. to the Rocky Mountains, vol. i. p. 104.) "the highest: northern range of this species, is Canada, in North America; it is also found as far south as the river Oronoco, in South America.

"This species is leanest in February and March, and in best condition in October and November. The rutting season commences in November, and continues about one month, terminating generally about the middle of December. During this season the neck of the male becomes very much dilated.

"The fawn towards autumn looses his spots, and the hair becomes grayish, and lengthens in the winter. In this state the deer is said by the hunters to be in the gray.

" This coat is shed in the latter part of May and 
beginning of June, and is then substituted by the reddish coat; in this state the animal is said to be in the red. Towards the last of August, the old bucks begin to change to the dark bluish colour; the doe commences this change a week or two later; in this state they are said to be in the blue; this coat gradually lengthens until it comes to the gray. The skin is said to be toughest in the red, thickest in the blue, and thimnest in the gray; the blue skin is most valuable. The horns are cast in January; they lose the velvet the last of September, and beginning of October. About the middle of March, Mr. Peale shot a large doe, in the matrix of which were three perfectly formed young, of the size of a rabbit."

This species displays great ennity towards the rattlesnake, which enemy they attack and destroy with singular dexterity and courage; when the deer discover one of these reptiles, they leap into the air to a great distance above it, and descenc? with their fore feet brought together, forming a solid square, and light on the snake with their whole weight, when they immediately bound away; they return and repeat the same manœuvres until their encmy is completely destroyed.

"From May until July, the female of the common decr conceals her young whilst she goes to feed; it is at this time that the hunters take advantage of the materual feelings of the animal to 
secure their prey. They conceal themselves and imitate the cry of the fawn; the solicitude of the parent animal for her young, overcomes her usual caution, and believing she hears the cry of her offspring in distress, hurries towards the spot where the hunter lies concealed, and falls an easy prey.

"A variety of this species, three specimens of which occurred at Engineer Cantonment, had all the feet white near the hoofs ; this white extremi$t y$ is divided upon the sides of the foot by the general colour of the leg, which extends down near the hoof, leaving a white triangle in front, of which the point is elevated rather higher than the spurious hoofs. 'The black mark on the lower lip, rather behind the middle of the sides, is strongly characterized.

"Total length, without the hair at the tip of the tail, five feet four and three-fourths of an inch; length of the ear, six inches and a half; trunk of the tail, nine inches and a half; weight, in Febru. ary, one hundred and fifteen pounds." (Say.)

\section{Species.}

5. Cervus macrotis, (Great Eared Deer,) Say, Maj. Long's Exped. to the Rocky Mountains, vol. ii. p. 88. Black Tailed Deer? Lewis and Clark, vol. i. p. 77. Mule Deer, Ejusdem.

Char. Essent. Light reddish-brown above; sides of the nose, and upper portion of the fore 
part of the nose, dull cinereus; back intermixed with blackish-tipped hairs, which form a distinct line on the neck, near the head tail ; reddish-cinereus, black at the tip.

Dimensions. Length from the base of the antlers to the origin of the basal process, two inches; from the basal process to the principal bifurcation, from four and a half to five inches; terminal prongs of the anterior branch, four to four and a half inches; of the posterior branch, two and a half to three inches; from the anterior base of the antlers to the tip of the superior jaw, nime and a quarter inches; of the ears, seven and a half inches; of the trunk of the tail, four inches; of the hair at the tip of the tail, from three to four inches.

Description. Antlers slightly grooved, tuberculated at base, a small branch near the base, corresponding to the situation and direction of that of the $\boldsymbol{C}$. virginianus, the curvature of the anterior line of the antlers is similar in direction, but less in degree, to that of the same deer; near the middle of the entire length of the antlers, they bifurcate equally, and each of these processes again divides near the extremity, the anterior of these smaller processes being somewhat longer than the posterior one. The ears are very long, extending to the principal bifurcation, about half the length of the whole antler; the lateral teeth are larger in proportion to the intermediate teeth 
than those of the virginianus; eye-lashes black, the lachrymal aperture larger than in the latter species, the hair also coarser, and undulated and compressed like that of the Elk.

The colour is light reddish-brown above; sides of the head and hair on the fore portion of the nose above, dull cinereus; the back is intermixed with blackish tipped hairs, which form a distinct line on the neck, near the head; the tail is of a pale reddish cinereus colour, and the hair at tip is black; the tip of the trunk of the tail is somewhat compressed, and is almost destitute of hair beneath; the hoofs are shorter and wider than those of the virginianus, and more like those of the Elk.

Inhabit the most remote north-western territories of the United States.

\section{Fossil Deer.}

1. Cervus americanus, (Nob.)

Fossil Elk, of the United States.

In the Transactions of the American Philosophical Society, (vol. i. New Series, p. 375. pl. 10. fig. 4, there is for the first time, a description of the skull of a fossil animal, by the late Dr. Caspar Wistar, presented by Mr. T. Jefferson to the Society. There can be little doubt, that this skull is the remains of an extinct species of the genus Cervus; and is found to possess many characters in common with the Elk, (Cer- 
vus canadensis Briss.) though it has also many characters which distinguish it from all other species living or fossil, which have hitherto been introduced into the systems. The fossil consists of a skull, but the greater portion of the face, together with both jaws and teeth are destroyed; the posterior portion, together with one side, is in a tolerable state of preservation.

Dinensions. The breadth of the cranium at its narrowest part, which is behind the horns, is 4.65 inches; the greatest breadth, which is immediately above the condyloid processes, is seven inches; greatest depth, from the top of the occipital surface to the posterior margin of the occipital foramen, is 5.25 inches; depth from between the horns, through the sphenoid bone, is 4.7 inches; length of the skull, from the superior margin of the occipital surface to the space between the horns, 6.37 inches; the posterior or occipital surface of the fossil, bears a much closer resemblance to that of the Cervus canadensis, than to that of the Cervus alces, or to any other species. We shall, therefore, compare it with the Elk.

The whole skull is longer than that of the Elk; the occipital surface proportionably broader; the posterior and inferior base of the horns is concare in the fossil, and the surface for the attachment of muscles beneath the horns on the sides of the occiput, is much more extensive in the latter: the 
horns (about four inches only of one remains in the fossil) proceed in a perfectly straight and lateral direction, and the portion of the forehead between the horns is almost straight in the fossil; in the two last characters it is peculiar; there is also a much greater distance from the skull to the basal knob of the horns in the fossil.

A complete set of horns, or jaws containing teeth, belonging to this animal, have not yet been discovered; but in a collection of bones disinterred at Big-bone-lick, which we have received a few weeks since, (and for which we are indebted to the politeness of Major S. H. Long, there are fragments of jaws, together with a number of molar teeth, which I have every reason to believe belonged to the fossil Elk under consideration. On comparing these teeth with those of the recent Elk, very little difference is observable, except that they are longer and more compressed at their crowns.

Locality. The bones of the American fossil Elk have hitherto been discovered only in the morass near the falls of Ohio, called Big-bone-lick, in company with the bones of the Mastodon, \&c.; we have lately examined some designs in possession of Dr. Bigsby, which appear to represent the femur, the humerus, and portions of the horns of a fossil Elk from Canada.

Third Tribe. Prominences of the os frontis furnished with a horny sheath. composed of agghn- 
tinated fibres, which grow by laminæ, and remain during life.

\section{Genus.}

Antilope, Pallas, Schreb. Gmel. Scopoli, Erxleb. Bodd. Cuv. Geoff. Illig.

Tragus, Klein.

Capra moschus, Linn.

Gazella, Briss.

Tragulus, Briss. Klein.

Antilocapra, Ord.

Mazama, Rafinesque.

CHARACTERS.

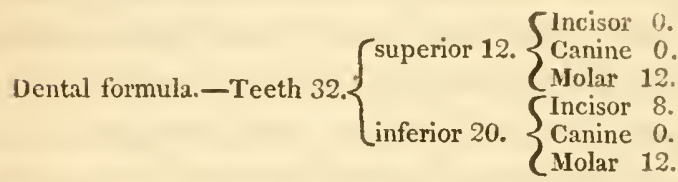

Incisor's generally equal, and contiguous at their borders; sometimes the two intermediate are very broad, a little separate from each other, leaning against the lateral ones by their posterior face.

Horns in both sexes, or in the male only, covering an osseous process of the frontal bone, which is generally solid and without sinuses, round, variously contorted, often marked with transverse lings, or with a projecting spiral crest, sometimes bifurcated.

Facial line more or less straight, often lachrymal depressions or naked sub-orbitar grooves, sereting a peculiar fluid. 
A muzzle, or demimuzzle for the most part; none in some species; ears large, pointed and moveable; eyes often very open; tongue smooth; body generally slender, like that of the Deer; legs slender; tail short or moderate; sometimes inguinal pores or deep cuticular folds in the groin.

Brushes or tufts of hairs on the wrists of some species.

Two or four mammæ.

Covering generally sparse, and ornamented with lively colours, agreeably disposed; no beard on the chin.

They possess a gall-bladder.

Habit. Peaceable, and altogether herbivorous; generally uniting in troops; living for the most part beneath the torrid zone; some in temperate climates, and others in northern latitudes, on the summits of mountains covered with snow; rapid in their motions like Deer; bringing forth one or two young at a birth.

Inhabit Africa, India, Tartary, the Alps of Europe, and Rocky Mountains of America.

\section{Eleventh Subgenus, (of authors.)}

Antilocapra, Ord, Blainville.

Horns of both sexes moderate, compressed, recurved posteriorly towards the point, in form of a hook, and furnished with an anterior antler; no muzzle; no lachrymal depressions; no tufts on the wrists: general form that of the other Antelopes. 


\section{Species.}

1. Antilope americana.

Antilocapra americana, Ord, Journ. de Phys. 1818. Cervus bifurcatus, Rafinesque. Antilope bifurcata, Smith. Antilope furcifer, ejusd. Trans. Linn. Soc. vol. xiii. pl. 2. C'erf á bois recourbè, Cervus hamatus, Blainv. Nouv. Bull. Soc. Philom. 1816, p. 80. Schreb. Goldfuss. tab. 264. Desm. Nouv. Dict. d'Hist. Nat. t. 29. p. 542. Antilope furcifer, Desm. Mamm. Prong-horned Antelope.

Nоте.-It is somewhat remarkable that so many synonymes should have occurred for an animal so lately discovered as the subject of the present description. 'The Prong-horned Antelope, is now generally admitted to be a true Antelope, and not the type of a distinct subgenus; we know not on what authority $\mathrm{Mr}$. Smith has changed the specific name, (Americana,) under which Mr. Ord first described this species.

Char. Essent. Horns rugous, triangular at base, and provided with a very small antler, compressed and turned outwards, terminated superiorly in a recurved point, hooked backwards and rather outwards; colour reddish-fawn above, white beneath; hair rather short, stiff and coarse; a reddish mane upon the neck.

Dimensions. Length of the body, measured from the anterior part of the shoulders to the 
rump, two feet nine inches; lieight before, two feet nine inches; length of the tail, four inches; of the horns of the male, one foot; of the antlers, two inches.

Description. Horns slightly marked by transverse wrinkles and rugosities, rather inclined outwards, and turned backwards at their extremity, which is smooth; about two thirds of their height provided with a short antler, directed forwards; eyes large, and placed very high, under the base of the horns; ears pointed, one half the length of the facial line; base of the horns tufted; legs slender; tail short; hairs thick, stiff, coarse, flattened, undulating, and enclosing in their middle a sort of marrow; flanks black; exterior face of the fore legs, and tail above, of a reddish-fawn; breast, belly, interior of the limbs, buttocks, and beneath the tail white; top of the head white, as well as the cheeks and lips; face and nose of a deep chesnut; neck a reddish fawn above, with a white spot near the ear, and marked with white beneath; a reddish tuft of hairs on the back of the head and neck.

Inhabit south-western territories of the United States; (seen on the borders of the Missouri and great plains of Columbia by Lewis and Clark, a specimen in the Philadelphia Museum.

Note.-It is, without doubt, this animal described and badly figured by Hermandez. "Rerum 
medicarum Novæ Hispaniæ Thesaurus," \&c. p. 324. cap. 15. under the name of Mazame seu Ceruis.

\section{Genus.}

Capra, Linn. Pallas, Erxleb. Cuv. Geoft: Goat.

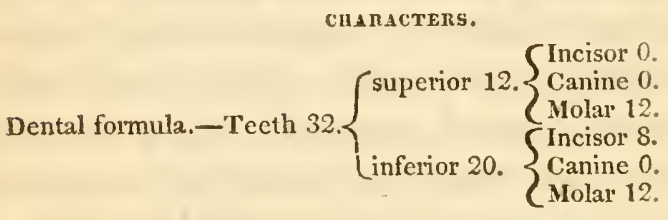

Incisors of nearly equal dimensions, regularly arranged and touching at their borders.

Horns directed upwards and outwards, compressed and wrinkled transversely; facial line straight or even, or somewhat concave; no muzzle; interval of the nostrils naked; no lachrymal depressions or suborbitar grooves; ears pointed, straight, and moveable; tongue smooth; body rather slender; legs rather robust; tail short; no inguinal pores; no tufts on the wrists; two mamma.

Coat composed of two sorts of hair; the interior very fine and soft, more or less abundant; the exterior long, or very long and smooth; chin most frequently furnished with a beard; some-

* It is this which in some of the Asiatic races, furnishes thr cashmern. 
times two cuticular appendages, or sorts of glands, hang from beneath the neck.

Testicles contained in a very voluminous scrotum.

Habiт. In the savage state the goats seek the most elevated and inaccessible places, and unite in troops more or less extensive, under the protection of an old male; these animals of all the ruminants display the most vivacity and intelligence; their vision is good; they hear at a distance, and their sense of smell is remarkably acute; they feed on herbs and shrubs; they bring forth two young at a birth.

Inhabit the Granitic chains of Europe and Asia, also the Rocky Mountains of North Ame. rica.

\section{Species.}

1. Capra montana.

Ovis montana, Ord, Jour. Philad. Acad. Nat. Sciences, vol. i. part 1. p. 8. 1816. Rupicapra americana, Blain. Antilope americana, Ejus. Nouv. Bull. Soc. Phil. 1816. p. 80. Mazama sericea, Rafin. Amer. Mon. Mag. 1817. p. 44. Antilope lanigera, C. H. Smith, Trans. Linn. Soc. p. 38. 1822. Tab. 4. vol. xiii. Rocky Mountain Goat.

We have here an animal, described for the first time in 1816, which has already been classed under four distinct genera, with nearly as many specific appellations. This can only be accounted for from the remoteness of the regions inhabited 
by these animals, and their consequent scarcity; one specimen only of the prepared skin having reached any cabinet in the world, which is that at present in the Museum of the Linnean Society of London, from which the plate is taken accompanying Mr. Smith's description of this animal. Concerning this figure, we must here remark, that though the drawing from which it has been engraved, appears to have been very spirited, nevertheless, as we are assured by Mr. Ord, who repeatedly examined the specimen, the direction of the tail is not natural, and further, the transverse wrinkles on the bases of the horns are much too deep. In the horns of this animal formerly attached to the skin in the Philadelphia Museum, (which appear to have belonged to an animal in the second year of its age, ) there exists no transverse wrinkles, only three or four slight undulations on the anterior base of the horns; they are nearly four inches in length, slightly recurved, perfectly black, and obsoletely striated longitudinally, hollow to the point; the base of the cavity measures one inch in diameter. This individual, though young, is by no means destitute of long hairs, which almost exclusively occupy the back, from the shoulders to the tail.

The reasons which have induced us to range this animal under the genus Capra, will be found detailed below; the specific name under which 
Mr. Ord has described it, having the right of priority, must be retained.

Char. Essent. Horns short, conical, slightly curved backwards, black, and slightly annulated in the old animal; the colour of the animal entirely white, furnished with long silky hairs, and a fine wool beneath the hair; no mane.

Dimensions. In bulk it exceeds the sheep.

Description. Body elongated, but little elevated on the legs; facial line straight; ears rather long and pointed, covered on the inside with long hairs; the neck short; the tail stumpy and directed upwards; the whole structure of the animal robust; the colour is entirely white; the bulk of the animal is considerably increased by a thick coat of long straight hair, of a yellowish tinge; side of the lower jaw, and beneath the throat, furnished with a long beard; beneath the long hair, the skin is covered with a close downy wool, of a clear white colour, and in young animals feeling like unspun cotton; on the face and legs the hair is short and close, similar to that of the sheep and goat; the eye-lashes are white; the horns are about five inches long, above an inch in diameter at base, bending slightly backwards, having two or three annuli, and terminating in a point not always obtuse; the legs exceed in thickness those of a calf; the fetlocks are short and perpendicular. 
and the hoof's are of a jet black, high, broad, and with deep grooves in the soles.

Remarкs. Like the Goat, the facial line is nearly straight in the $C$. montana, this line being more or less arched in the Sheep and Antelope. Like the Goat, the $\boldsymbol{C}$. montana is furnished with a long beard; the Sheep and the Antelopes being destitute of this appendage.

In the form and size of the hoofs; in the direction of the tail; in the form of the snout; in the strength and proportion of the limbs in particular, and of the body in general, our animal resembles the Goat, and is unlike the Sheep and Antelopes; the latter animals have, furthermore, never been known to possess a covering consisting of fine long hair, and wool of exceedingly delicate texture, whilst, in this respect, our animal bears a striking analogy to the Cashmere Goat. Though the horns are at best uncertain characters, varying as they do in form, in similar species, yet, even in this respect, our animal offers stronger analogy to the Goat than to the nearest allied congenera.

The horns of the young male Goat are very similar to those of the Capra montana.

Habir and Covnrry. For the following informaion concęrning this highty interesting animal, we are under many obligations to Major S. H. Long, being chiefly the copy of a letter addressed by him to the Philadelphia Agricultural Society. 
"The information I am able to furnish, was obtained on the late expedition to the sources of $\mathbf{S t}$. Peter's river, \&c. and was procured principally from Donald $\mathbf{M}$ 'Kinzie, Esq. (of the family of Sir Alexander M-Kinzie, stationed at the junction of the Assiniboin and Red rivers, in the capacity of chief factor for the Hon. H. B. Company on that: station; the intelligence furnished by this gentleman was from personal observation.

"The Rocky Mountain sheep inhabit the elevated region comprised in that portion of the mountain range from which its name is derived, situate between the forty-eighth and sixtieth parallels of north latitude.* They are found in great numbers near the head waters of the north fork of Columbia river, where their flesh constitutes the principal food of the natives. The country at the sources of Muddy river, (Marais river of Lewis and Clark, Saskatchawin and Athabaska rivers are also inhabited by them; but they are said to be less numerous on the eastern slope of the Rocky Mountains than upon the western; they are seldom or never seen at a distance from the mountains, the climate and productions of which appear best adapted to their nature and mode of life. In summer they resort to the peaks and ridges in quest of pasture, but retire to the valleys in win-

* Lewis and Clarke obscrved this animal as low as forty-five degrees of north latitude. Vid. Exped. up the Missouri, vol. ii, pp. $35,49$. 
ter. The size of the animal is nearly the same of the common sheep; their fleece is white, interspersed with long hair, protruding beyond the wool, and standing erect on the surface of the body, which gives them a shaggy appearance; their horns are short, merely projecting beyond the wool of the head, and slightly arcuated backwards; these, together with their hoofs, are black, while the other parts of their bodies are uniformly white; their flesh has a musky favour, and is, at best, unsavoury.

"They are of easy access to the hunter, who seldom pursues them unless compelled by hunger. Their fleece is esteemed of little value by the traders, and are used only as a covering to the feet during winter; their skin is of a remarkably thick and spongy texture. It has been asserted by good judges, that the silky fineness of the wool is not surpassed by that of the Cashmere Goat." (S. H. Long.)

\section{Genus.}

Ovis, Linn. Briss. Erxleb. Gmel. Bodd. Cuvier, Geoff.

Capra, Illig.

Algionomus, Pallas, Ranzani.

$$
\text { Dental formula.-Teeth 32. } \begin{cases}\text { superior } 12 . & \left\{\begin{array}{l}
\text { Incisor } 0 . \\
\text { Canine } 0 . \\
\text { Molar 12. } \\
\text { inferior 20. }
\end{array}\right. \\
\left\{\begin{array}{l}
\text { Incisor 8. } \\
\text { Canine 0. } \\
\text { Molar 12. }
\end{array}\right.\end{cases}
$$


Incisors forming an entire arch, regularly approximate at their borders.

Snout without a muzzle; facial line arched.

Horns large, angular, wrinkled transversely, twisted laterally in a spiral form, and enveloping an osseous arch, cellular in structure.

No lachrymal depressions; no beard to the chin; ears moderate, pointed; legs rather slender, without tufts at the wrists; two mammæ; no inguinal pores; tail more or less short, inflected or depending.

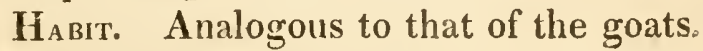

Inhabit both continents.

\section{Species.}

\section{Ovis ammon.}

Mouflon argali, Erxleb. Gmel. Shaw, Gen. Zool. vol. ii. part 2. plate 201. Ovis argali, Bodd. Stepnie baranni, G. S. Gmel. Voy. in Siberia, tom. i. p. 368. Steller, Kamsh.? p. 127. Ovis fera sibirica, vulgo Argali dicta, Pallas, Spicilegiæ Zool. fasc. xi. p. tab. 1. Ovis mon. tana, Geoff. Ann. du Mus. tom. 2. pl. 60. Mouflon d'Amerique, Ovis montana, Desm. Mamm. (Encycl. pl. puppl. 14. fig. 4.) Big-horn, Lewis and Clark. Musimon, Pliny. Ophion, of the Greeks. Argali of the Siberians. Kamennoi barron, or sheep of the rocks, of the Russians. Taye, of the Monqui-Indians. Sheep of California, Hernandez. Goadinachtsch, of the Kamschat. 
kans. Rikun-donotoh, of the Kuritians, from its inhabiting the loftier parts of the mountains. Ibex, or Wild Goat, of Clavigero. Cul blanc, of the Canadians. The Argali, or Mountain Sheep.

The following description is taken from specimens, male and female, in the Philadelphia Museum; on comparing which, with the descriptions and figures of the Argali of the old continent, not the slightest specific difference is observable.

Char. Essent. Horns of the male very large, and strong, triangular; flattened before, striated transversely; those of the female compressed and falciform; hair during summer, sparse, grayishfawn; during winter, thick, hard, reddish-gray, with white about the nose, the throat and beneath the belly; a large yellowish-white space about the tail at all times.

Dimensions. Total length, from the tip of the snout along the back to the base of the tail in the direction of the curvatures of the body, four feet five inches; length of the tail five inches; side of the head from the tip of the nose to the posterior base of the ear, twelve inches; facial line, from the tip of the nose to the occiput, sixteen inches; length of the fore leg, from the brachio-cubital joint to the fetlock joint, nineteen inches; of the fetlock joint three inches; of the hoof, anteriorly, two inches five-tenths; height of the same, laterally, one inch five-tenths; length of the base three 
inches ; length of the posterior leg, from the tibiofemoral joint to the fetlock, twenty-two inches five-tenths; of the fetlock joint two inches; of the hoof two inches three-tenths; length of the horns, following the outer curvature, two feet ten inches; circumference of the base fifteen inches five-tenths; length of the ear three inches fivetenths.

Description. Horns of the male, very large, the bases very near the eyes; curved first backwards, then forwards, with the points curved rather upwards and outwards; deeply wrinkled from their base to one half their length, the rest being more smooth, triangular at base, the largest face anteriorly; horns of the female very slender in comparison with those of the male, nearly straight, almost without wrinkles, and resembling very much those of the domestic he-goat; ears rather broad and pointed, and very straight; neck having some pendulous folds; tail very short; colour of the animal during summer, a grayish-fawn, with a yellowish or reddish line along the back, and a large spot of the same colour surrounding the base of the tail, on the buttocks ; internal surface of the extremities, and the belly, of a still more pale-reddish (rather dirty white;) winter colour more reddish above, approaching to white on the snout, on the belly and under the throat.

Habit. Living in mountainous countries; they are exceedingly active. and are able to ascend 
precipices inaccessible to other animals; they leap from rock to rock, at great distances, and with incredible velocity; they go in troops of twenty or thirty individuals; they copulate in spring and autumn; the female brings forth one or two at a birth; during the rutting season the males engage in furious combats, and often break off each other's horns.

Inhabit the great Asiatic chain of mountains, particularly those which run north-east into Tartary. According to Gmelin, they inhabit southern Siberia. In North America, they inhabit the Rocky Mountains, about the fiftieth degree of north latitude, and the hundred and fifteenth degree of west longitude, extending south into California.

It is the opinion of eminent naturalists, that the Argali of both continents form but one species, having passed originally from one country to the other on the ice. They are supposed also to constitute the original stock of our domestic sheep. A figure of this animal was published by Venegas in 1758, under the name of Tayè or Tage. Noticia de la California, vol. i. p. 86 . printed at Macirid.

In the New York Medical Repository, (vol. vi. j. 238,1803, ) is a description, accompanied with an indifferent figure, of the Argali of North America. under the name of "Mountain Ram," by Mr. M.Gillivray, who states, that when travelling 
through the plains situated between the Saskatchawin and Missouri rivers, along the Rocky Mountains, in the fall of 1800 , he observed and killed several of these animals. The dimensions of the largest male were as follows-length, from the nose to the root of the tail, five feet; length of the tail four inches; circumference of the body four feet; height of the body three feet eight inches; length of the horn three feet and a half; girth at the head one foot three inches.

Mr. M.Gillivray says that the Cree Indians, or Kristianeaux, distinguish this animal by the name of $\boldsymbol{M y}$-attic, or ugly Rein-deer. The slave nations, comprehending the Blood Indians, Piecans, and Black-feet Indians, call it Ema-ki-ca-now, which also signifies a kind of deer.

According to professor Pallas, this animal formerly inhabited the regions about the upper Irtish, and some other parts of Siberia, where it is no longer seen since colonies have been settled in these countries. It is common in the Mongalian, Songarian, and Tartarian Mountains, where it enjoys its favourite solitude. The Argali is found likewise on the banks of the Lena (in 1794) up as high as the sixtieth degree of north latitude, and it propagates its species even in Kamschatka. From the mountains of Persia there is the stuffed skin of one in the Museum of the Imperial Academy of Sciences, sent by Gmelin. Dr. Pallas further states, that in the year 1768 he observed 
garments made of the hair and wool of this animal, from the islands lying between the continent of America and Kamschatka, which is a further confirmation of the identity of the species inhabiting both continents. Vid. Account of the different kinds of Sheep, \&c. by Dr. Pallas, 1794.

\section{Genus.}

Ovibos, Blainville.

Bos, Pennant, Gmel. Shaw, Bodd. Illig. Cuvier.

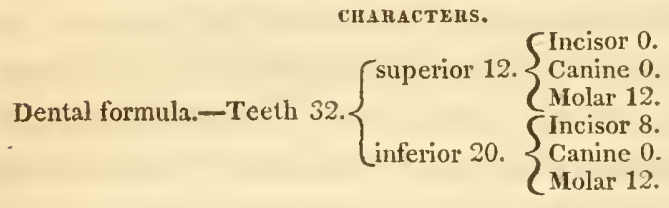

Body thick, contracted; legs strong; head short; forehead very elevated; facial line long and abrupt; horns very strong, directed laterally, neither angular or knotty; no muzzle, (in which it particularly differs from the genus Bos;) ears short, receding; eyes small; no canal in the upper lip; no lachrymal depressions; tail very short; hairs in tufts and long; no inguinal pores.

\section{Species.}

1. Ovibos moschatus, (Encycl. pl. suppl. 14. fig. 3.) Musk Ox, Penn. Quad. vol. i. p. 31. Ejusd. Arct. Zool. vol. i. p. 8. pl. \%. Bos moschatus, Gmel. Bodd. Shaw, Gen. Zool. vol. ii. part 2. p. 407. pl. 212. Bæuf musquè, Buff. Hist. Nat. suppl. tom. vi. pl. 5. la tete. Ouibos, Blain. Nouv. Bull. de la 
Soc. Phil. Juin, 1816. Cuvier, Recherches sur les Ossem. Foss. 1 edit. tom. iv. p. 59. pl. 3. fig. 9. et 10 .

Char. Essent. Horns projecting from the summit of the head, very near to each other, very broad at their base, curving first downwards, then elevated laterally at the point; no muzzle; coat composed of long woolly hair, of a deep brown colour.

Dimensions. Size of a heifer two years old.

Description. (Male.) General aspect more resembling a large sheep than an $\mathrm{ox}$; body and head elongated; front very elevated, and furnished with a sort of mane of long hairs diverging from a common centre and covering the roots of the horns; the latter are black, smooth, wide, touching at their base. then curving forwards and rather downwards, applied to the sides of the head, then elevated suddenly upwards and backwards; ears short, receling, entirely corered with soft thick hair; eyes very small and widely separate from each other, and very far from the end of the nose, comprised in the first arch formed by the horns; nose or facial line very much elongated, blunt as in the ram; nostrils lateral and small, placed nearer together than those of the ox, but less near than those of the ram; no muzzle; mouth very small; lips rather thick, the superior offering no medial groove: legs strong and 
short; hoofs larger on the fore than on the hind feet, of a deep brown colour, and converging towards each other on each foot; tail very short, and concealed by the rump; neck, trunk and origin of the legs, clothed with two kinds of hair, a very thick and long wool, and fine bristles, which traverse it; extremities, from one half of the forearm, and the commencement of the hind legs, furnished with short and compact hairs near the skin; beneath the neck and lower jaw furnished with very long hair, of the same nature with those of the back; hairs of the face, shorter the nearer they approach the end of the nose, which is entirely covered with them; general colour, a reddish-brown, with nearly black-brown in some places; around the nostrils, upper lip and extremity of the lower lip, white.

Note--(Fossil skulls of a species of Bos somewhat similar to the above, have been found in Siberia, figured by Cuvier, Recherches, sur les Ossem. Foss. vol. iv. pl. 3. fig. 9 and 10.)

Habit. The Musk buffaloes, or oxen, go in droves of twenty or thirty; frequent sterile mountains, and seldom visit woorly countries. They are fleet, and climb rocks with facility; their flesh is musky.

Inhabit North America; abound between the sixty-sixth and seventy-third degrees of north latitude, on the western side of Hudson's bay. 
It is supposed that the fossil skulls found in Siberia, have been carried there on the ice; should they really prove to have belonged to the musk oxen, which is not clearly ascertained, as Cuvier has remarked.

\section{Genus.}

Bos, Linn. Briss. Erxleb. Bodd. Cuv. Geoff. Illig.

Taurus, Storr.

The $O x$.

CHARACTERS.

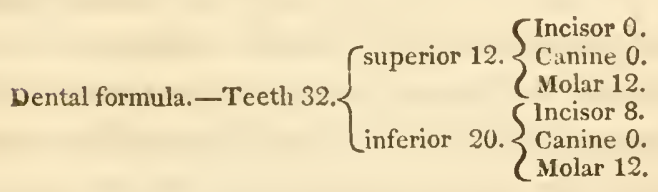

Inferior incisors regularly arranged, broad; body of large size, supported by stout legs; head powerful, facial line straight; ears large, moveable; eyes large; tongue long and smooth; a large muzzle at the end of the snout; no lacrhymal depressions; horns simple, conical, smooth, a transverse section circular, of various curvatures, but often directed laterally, with the point elevated.

A dew-lap, or longitudinal cuticular fold beneath the neck, more or less pendant; tail moderate, or rather long, terminated by a brush of long hairs; four mammæ; no inguinal pores; no tufts of hairs on the wrist. 
НАвіт. Essentially herbivorous; the wild oxen go in troops more or less numerous, according to the species, and frequent woorls or plains, where they can find nourishment; the males are more or less brave, and capable of defending themselves against the attacks of wild animals, with their horns.

Inhabit warm and temperate climates; eastern Europe; the mountains of 'Thibet; India; the southern extremity of Africa; the western territories of the United States, are those places where they exist in a savage state. The domestic cattle, of which the primitive stock appears to be lost, have been introduced into all civilized countries.

Fossil remains prove that four species of this genus formerly inbabited the old continent, and two species the new continent, of which one of the former appears proper to Siberia.

\section{Species.}

1. Bos americamus, Gmel.

T'aurus mexicanus, Hernandez, Mex. p. 587. Tauri vaccaque quiuire regionis, Fernand. Anim. p. 10. The Buffalo, Catesby, Carol. p. 28. tab. 20. Bouf sauvage, Du Pratz, Louisian. t. 2. p. 66. Bison, Buffon, suppl. t. 3. pl. 5. .American Bull, Penn. Quad. tab. 2. fig. 2. Buffulo, Shaw, Gen. Zool. pl. 206. Bos bison, Erxleb. Linu. Bos urus, var. Bodd. Bison, Warden, vol. v. p. 643. Long's Expedition to the Rocky Mountains. 
Char. Essent. Horns rather small, round, placed on the side of the head, very distant from each other, directed first laterally, then upwards.

Withers very projecting; head, shoulders, and superior parts of the anterior extremities, covered with long woolly hair, very abundant; a beard; tail very short.

Dinensions. 'Total length seven feet ten inches; of the tail one foot seven inches; of the head one foot seven inches; height at the withers four feet eleven inches; at the rump three feet eleven inches; (some of the largest weigh from 1600 to 2000 pounds.)

Description. Form contracted; head short and thick; horns small, growing horizontally from the sides of the head, and then elevated upwards; eyes rather small; shoulders very much elevated; posterior portions of the body and hind legs very light proportionably; a very thick woolly hair covering the summit of the head, the cheeks, facial line, the neck and the shoulders ; long straight hair forming a thick beard, hanging beneath the chin, and broad ruffles towards the upper part of the fore legs; flanks, rump, thighs, and hind legs clothed with very short and compact hair; tail covered with sparse hairs, and terminated with a tuft.

General colour, black on the head, chesnut on the shoulders, and a deep brown on the back, the sides, the belly, and fore parts ; hair longer during 
the winter season, particularly on the posterior parts of the body. 'The spinous processes of the anterior dorsal vertebræ measure from one foot and a half to two feet in length; the diameter of the bodies of the vertebra being two inches.

Haвiт. The American Bison or Buffalo inhabit the great prairies west of the Mississippi; they often unite in immense troops, supposed in some instances to amount to 10,000 . During the rutting season, about the middle of June, the males engage in mortal combats, disputing for the females ; generally speaking, they are rather timid, but when wounded, or during the rutting season, they become very fierce.

Inhabit the temperate parts of North America; they were observed in the two Carolinas soon after the arrival of the first colonists. They have long since been exterminated from Pennsylvania, and are not known to exist at present east of the Mississippi river; they were observed in a savage state in Kentucky so late as the year 1766, but have gradually retired before the white settlers, and appear to have concentrated in the plains of Missouri.

For a particular account of the geographical distribution of this animal, Vid. Major Long's Expedition to the sources of the St. Peter's River, \&c. 


\section{Fossil Ox.}

\section{Species.}

\section{Bos bombifrons, (Nobis.)}

This species has not heretofore been introduced into the systems, nor even noticed by systematic writers. It was first described from a fossil skull, presented to the American Philosophical Society, by Mr. 'T. Jefferson. The description was drawn up by the late Caspar Wistar, M. D. and published in the transactions of the society. (Vol. 1st, New Series, p. 379. pl. xi. fig. 10 and 11.)

Characier. Top of the head, between the horns, strongly arched and projecting; facial line forming rather an acute angle, with the occipital surface; horns first project laterally from the sides of the head, then curve downwards, they are placed on the skull at a considerable distance anterior to the union of the facial and occipital surfaces.

Descrirtion. Part of the nose and face of this skull are destroyed, as well as the jaws and teeth; in size and general form it approaches nearest to the skull of the Bos americamus, but differs in the following particulars. The space on the top of the head between the horns, is nearly straight in the Bison, whereas it is prominently arched in the fossil: in the Bison, the horns project from the sides of the head near the union formed by the 
occipital and facial surfaces, first in a lateral direction, then curve upwards, tapering, rather slencier and pointed. In the fossil, the horns project from the sides of the head, at a considerable distance anterior to the union of the facial and occipital surfaces, first laterally, then curve downwards; which disposition of the horns distinguish this fossil skull from all other skulls of this genus, fossil or recent; the horns are thicker, less tapering, and less pointed than those of the Bison. The concavity which exists to a greater or less extent in all animals of this genus, beneath, and posterior to the base of the skull, is much more extensive in the fossil than in the bison skull. The occipital surface is less broad in the fossil skull. From which it is shown, that in former times a species of Bison inhabited this country, differing essentially from the Bison of the present day.

In the collection of fossils presented by Major Long, from Big-bone-lick, are the fossil teeth of a species of Bos, which most probably belonged to the fossil animal now under consideration. On comparing these teeth with those of the recent bison, very little difference is observable, excepting that they are thicker at the crowns, and more deeply grooved on the sides, and altogether more robust.

Locality. From Big-bone-lick, near the falls of Ohio. (State of Kentucky.) 


\section{Species.}

2. Bos latifrons, (nobis.)

Broad headed Fossil Ox.

The specimen, a portion of the skull with a part of one horn attached, is in the Museum of the American Philosophical Society, and is the same figured in Cuvier's Anim. Fossiles, ist ed. vol. iv. pl. 3. fig. 2. Ann. du Mus. d'Hist. Nat. (Ejusdem.)

Description. This skull differs very little from that of the Auroch, (Bos urus, Bodd. Pallas, Cuv.) The forehead is arched, broader than high; the horns are attached two inches before the line, formed by the union of the facial and occipital surfaces, which latter form an obtuse angle; the plane of the occiput represents a semicircle; the horn is twenty-eight inches in circumference at its base.

Locality. State of Kentucky. Similar fossil skulls have been found in Europe, on the borders of the Rhine, near to Cracovie in Bohemia, \&c. 


\section{Order CETA.}

Characters. Body pisciform, terminated by a caudal appendage of a cartilaginous nature, and horizontal.

Two anterior members only, in form of fins; the bones of which are very flat and short.

Head joined to the bodly by a very short and thick neck, composed of seven cervical vertebre, very thin, and in part anchylosed with each other.

Two pectoral or abdominal nammæ.

Ears, external meatus very small; skin more or less thick, without any hair ; brain large; the hemispheres much developed.

Petrous portion of the temporal bone, which contains the internal organ of hearing, entirely separate from the head, or attached only by ligaments.

Pelvis, and bones of the posterior extremities. represented by two rudimentary bones, lost in the flesh.

Like all other mammalia, they respire with lungs, are warm-blooded, and possess a double circulation, \&c.

Habiт. The largest animals known; entirely aquatic; for the most part carnivorous; sivimming by the aid of their tail, which moves upward and downward. and not from right to left as that of 
fishes; viviparous; suckling their young as other mammifera, \&c.

Inhabit nearly all seas, at least the whales properly so called, but they appear to prefer the polar regions to temperate or warm latitudes. The Herbivorous cetacia on the contrary, are peculiar to the equatorial regions.

\section{Family, CETACEA Herbivora, Sirenia.}

Character. Crowns of the molar teeth flat; furnished with tusks sometimes in the upper jaw.

Two pectoral mammæ; whiskers in some instances large.

Nostrils placed at the end of the snout; nasal apertures in the skull situated superiorly.

Body very massive.

\section{Genus.}

.Manatus, Rondelet, Linn. Scopoli. Storr, La= cep. Cuv. Geoff. Illig:

Trichechus, Linn. Erxleb. Schreb. Shaw, Gmel. Manati, Bodd. Lamantin, Cuv.

Sea Cov.

\section{CHARACTERS.}

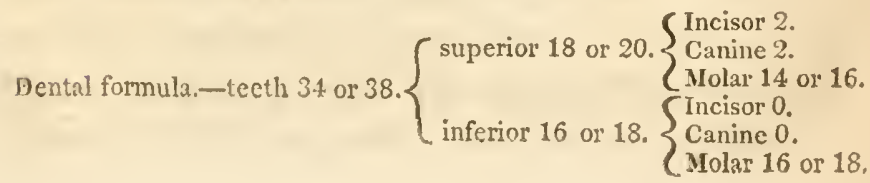


The incisors very small, existing only in the fetus.

Adults have only thirty-two teeth, as four molars fall in early life.

Crowns of the molars present two transverse tubercles, with three points at their summits in the young tooth; the superior teeth square; the inferior oblong.

Head not distinct from the body; eyes very small, placed superiorly, between the end of the nose and meatus auditorius externus, which is scarcely apparent.

Tongue oval; posterior parts of the body very thick, depressed and rounded at the end, without a caudal fin, properly so called.

Vestiges of nails on the borders of the pectoral fins.

Whiskers composed of a fasciculus of enormous hairs, directed downwards, and forming on each side a sort of corneous tusk.

Skin naked, very thick and rugous. Penis of the male terminated in a gland, enlarged in form of a mushroom, as in the horse.

Sixteen pairs of ribs, thick, and solid, the two first only articulating with the sternum.

Stomach divided into many pouclies. Cœcum bifurcated. Colon capacious.

Habiт. These animals live in societies, and feed on vegetable substances; the male displays much attachment to the female, and she much tenderness towards her offspring, which she car- 
ries under one of her fins during the first few days of its existence; they sometimes thrust their bodies out of water in search of food along the shores of rivers.

It is supposed that the females of these animals have given rise to the fabulous reports concerning Mermaids; the form of their head, the position of their mammæ, which become very much enlarged during the period of suckling, together with their anterior extremities, might have considerable effect on the imagination of a mariner.

\section{Species.}

1. Manatus latirostris, ${ }^{*}$ (nob.) Jour. Phil. Acad. Nat. Sciences, v. iii. part 2. p. 390. pl. 13. fig. 1, 2, 3.

This species is only known as yet by the comparison of the skull with those of the $M$. americanus, (Cuv.) and $\mathcal{M}$. senegalensis, (Ejusdem;) the latirostris resembles the latter much more closely than the former, but possesses characters distinct from either; and I have accordingly named it provisionally.

$\mathrm{H}_{\mathrm{ABit}}$ and Distribution. They are found in considerable numbers, about the mouths of rivers, near the capes of East Florida, lat. 25'. 'The Indians kill them with the harpoon during the summer months. One Indian has been able to capture ten or twelve during a season. They measure from eight to ten feet in length, and are about the size of an $0 x$. 
It is probable that this is the species mentioned by Captain Henderson in his account of the British settlement of Honduras, (1809.*)

\section{Fossil Manatus.}

'The ribs and vertebræ of a gigantic species of Fossil Manatus have been discovered on the western shore of Maryland; the vertical diameter of an atlas vertebra being nine inches; transverse diameter of the same, eleven inches. (Vid.Jour. Phil. Acad. Nat. Sciences, vol. iv. p. 32. Notice of the Plesiosaurus and other fossil reliquix, \&c. by R. Harlan, M. D.)

\section{Genus.}

Rytina, Illig.

T'richecus, Gmel.

Manatus, Steller.

Stellerus, Cuv. Desm.

* 6 The male and female of this species of animal are usually found together, and whilst sporting on the surface of the different lagoons, are frequently destroyed by the harpoon or dart, in the use of which the slaves of the settlement, and the Indians of the neighbouring Mosquito nation, are wonderfully dexterous. The fiesh of this animal is particularly admired, and thought to resemble very closely that of veal; the tail, which forms the most valuable part of the Manati, after laying some days in a pickle prepared for it with spices, Sc. and eaten cold, is a discovery of which Apicius might have been proud, and which the discriminating palate of Elagabalus would have thought justly entitled to the most distinguished reward."-Henderson's account of Honduras. 1. 106. 


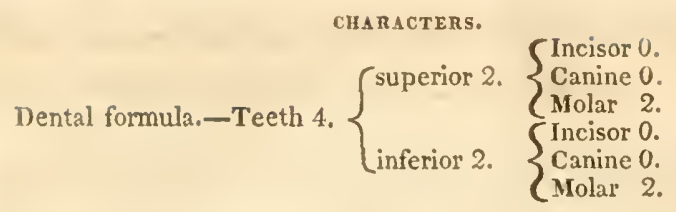

No implanted teeth, only a molar plate on each side of the jaws, attached by numerous vessels and nerves ; triturating surface unequal, and grooved by tortuous canals.

Body ventricose in the middle, and tapering gradually as far as the caudal fin.

Head obtuse, without a distinct neck.

No external ears.

Upper and lower lips double.

Eyes furnished with a cartilaginous membranc in form of a crest, which occasionally covers them. Nostrils placed towards the extremity of the snout.

Anterior extremities in form of palmated fins, like those of the sea turtle.

Caudal fin very broad, not very long, cruciform.

Skin destitute of hair, but clothed with a very solid, thick epidermis, and composed of compact tubes or fibres perpendicular to the skin.

Stomach simple.

\section{Species.}

1. Stellerus borealis, Cuv. Desun. Manutus, Steller. Trichechus manatus, Var. borealis, Gmel. Trichechus borealis, Shaw, Gen. Zool. Whaletailed Manati, Penn. Grand Lamantin du Kamschatka. Somnini, Nouv. Dict. d'Hist. Nat. 1. edit. 
Char. Essent. Head round; no tusks; tail cru* ciform; skin naked, very thick, corneous and fibrous.

Dimensions. Total length at least twenty-three feet; greatest circumference nineteen feet; weight about eight thousand pounds.

Description. Head round, confounded with the neck and body; mouth small, placed beneath the snout, and having the lips double, spongy, thick and swollen, furnished exteriorly with white bristles, recurved, and four or five inches long, forming whiskers; lower jaw projecting beyond the upper; opening of the moutl placed near the extremity of the snout, of equal width and length; eyes without eyebrows, but having at the large angle a cartilaginous membrane, covering them at the will of the animal; no external ear; anterior extremities destitute of toes, phalanges and nails : skin an inch thick, without hair.

Anterior extremity consisting of a scapula, humerus; two bones of the fore arm, a carpus and metacarpus, but no phalanges; pelvis composed of two ossa inominata, resembling the ulna of man. attached by strong ligaments to the twenty-fifth vertebra; a pubis; six cervical vertebræ, nineteen dorsal, and thirty-five caudal; stomach simple: intestines very long, (four hundred and sixty-six leet;) cæcum enormous; colon extensive and divided into great cells.

HaBIT. Residing in brackish water in the 
wouths of rivers; they pair in spring, and bring forth one at a birth; feeding on fuci; voice resembling the lowing of an $\mathrm{Ox}$.

Inhabit the most northern parts of the South Sea, and particularly the west coast of North America, and of those islands situated between this continent and Kamschatka.

Otho Fabricius states that a cranium of this species was found in Greenland.

2. Family, CETA, or Whales proper.

Characters. Sometimes provided with teeth, pointed or blunt, all of one description, on the borders of the jaw; sometimes in place of teeth, transverse corneous plates occupy the arch of the palate.

Two mammæ placed near the vent.

Nostrils situated on the summit of the head, very nearly approximated, serving to expel the water taken into the mouth, and are called blowers.

Larynx pyramidal, and penctrating the posterior nares.

Eyes flattened anteriorly, with a thick and solid sclerotica; tongue smooth; neither hair, eyelashes, nor whiskers; skin smooth and glossy, covering a thick layer of fat called blubber. 
Stomach consisting of five, sometimes seven distinct pouches; spleen divided into several distinct lobes.

\section{First Division.}

Small headed whales.

Characters. Head of usual proportion with the body.

\section{Genus.}

Delphinus, Linn. Briss. Erxleb. Gmel. Cuvier. Geoff. Illig.

Delphinapterus, Lacep.

Monodon, Fabicius.

Hyperoodon, Lacep.

Anarnacus, Lacep.

Uranodon, Illig.

Ancylodon, Illig.

Balana, Chemnitz. Dolphin.

Characters. Teeth all of one description, in form of canines; sometimes a little compressed, and serrated on their cutting borders; in numbers exceedingly various, from a total absence of teeth to as many as two hundred or not more than two.

Jaws more or less produced, in form of a beak, not provided with tusks; the blowing hole in form of a cross, on the top of the head.

Sometimes an adipose dorsal fin; sometimes a simple longitudinal cuticular fold on the back; tail flattened horizontally, and bifurcated.

No cæcum. 
HABIT. The Whales of this genus are the smallest of the family; they inhabit all seas and uncler very different latitudes; they swim commonly in small troops; and are of a carnivorous nature.

\section{Sul)genus. Delphinorhynchus, Blain.}

Snout prolonged into a long and thin beak, not separated from the forehead by a groove; jaws almost linear, with their borders both above and below furnished with numerous teeth; a single clorsal fin, or only a longitudinal cuticular fold, slightly elevated and placed rather posteriorly.

\section{Species.}

1. Delphinus coronatus, Freminville, Nouv. Bull. de la Soc. Phil. t. 3. No. 56. p. 71. pl. 1. fig. 2. A. B.

Char. Essent. Snout produced into a very long and pointed beak, the inferior longer than the superior; twenty-four teeth on each side below, and only fifteen above; a small dorsal fin; colour black above and beneath; two large, yellow, concentric circles on the forehead.

Dimensions. 'Total length from thirty to thirtysix feet; circumference more than fifteen feet.

Description. General form elongated; head small, relative to the body ; forehead convex, obtuse: jaws in form of a beak, very long and point- 
ed; the inferior being the longest, and having forty-eight very small, sharp, and conical teeth; the superior jaw having thirty; dorsal fin in form of a small cross, nearer to the tail than head; caudal fin forming an entire cross. The pectoral fins of moderate size; colour, uniform black, both above and beneath; forehead surmounted with two yellow concentric circles, the largest being two feet nine inches in diameter, and the interior nearly two feet one inch.

Haвiт. This Dolphin is common in the frozen ocean. They begin to show themselves in the seventy-fourth degree of north latitude; they abound particularly about the islands of Spitzbergen; are not very timid, and often approach the vessels. The water which they propel through their blowers, is expelled with much noise and velocity, appearing like light vapour; they seldom attain more than six feet in length.

2. Subgenus. Delphinus, Blain.

Snout prolonged into a morlerate sized beak, broad at its base, rounded at the extremity like the bill of a goose, and separated from the forehead by a sort of groove; jaws more broad posteriorly; borders furnished with teeth their entire length; a single dorsal fin.

Species.

1. Delphinis delphis, Desm. Mamm. p. 514 
(Encycl. Cetolog. pl. 9 and 10, fig. 2.) Vid. for the synonymes the Cetolog. of Born. p. 21.

Char. Essent. Jaws moderately prolonged, both of equal length, having on each side fortytwo or forty-five teeth, slender, cylindrical, pointed and rather arched, symmetrically arranged; dorsal fin placed on the posterior half of the body; eyes situated nearly on the same line with the rictus of the mouth; body black above, white beneath, both colours intermixing insensibly on the sides.

Inhabit the coasts of North America and of Europe,

Species.

Delphinus canadensis, White Dolphin of Canada, Duhamel, traité des peches, part 2. sect. x. pl. 10. fig. 4. Dauphin a bec mince, Cuv. Reg. Anim? Vulgo, Gulf-Porpoise, Herring-Hog.

Char. Essent. Head ventricose ; forehead elevated; snout very pointed, and abruptly separated from the forehead; colour of the body, white.

Inhabit the seas of Canada, coast of New England, Long Island, \&c.

4. Subgenus. Phocana, Cuvier.

No beak; snout short, and uniformly ventricose; numerous teeth in both jaws; a dorsal fin. 
Species.

1. Delphinus phocana, Briss. Regn. Anim. p. 371. No. 2. Linn. Gmel. Bonnaterre, Cetolog. p.

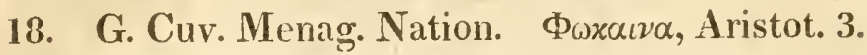
Phocana, Rondelet. Pisc. p. 473. Artedi, gen. 74. Dauphin marsouin, Lacep. Hist. Nat. des Cetacès, p. 284. pl. 13. fig. 2. Porpoise of the English. (Encycl. Cetolog. pl. 10. fig. 1.)

Char. Essent. Body and tail elongated; snout rounded; teeth compressed, cutting, cylindrical; from twenty-two to twenty-five on both sides of each jaw; dorsal fin situated near the middle of the back, nearly triangular and rectilinear; colour blackish above, and white beneath.

Dinessioss. 'Total length four or five feet.

These animals inhabit near the mouths of large rivers of both continents.

\section{Species.}

2. Delphinus gladiator.

Delphinus, Muller, Zool. Dan. Prodrom. p. \&. No. 57. Poisson à sabre, Pagè, voy. au pole nord, tom. ii. p. 142. Delphinus maximus, Olafsen, voy. en Iceland. Dauphin èpée de mer, Bonnaterre, Cetolog. p. 23. Dauphin gladiator, Lacepede, united to the Grampus by Cuvier, Regn. Anin. vol. i. p. 279.

Char. Essent. Body and tail elongated; top of the head very convex; snout cylindrical and short; jaws of equal length; teeth sharp and recurved; 
dorsal fin placed very near the nucha, and in length more than one-fifth the total length of the animal.

Dimexsions. Total length twenty-three to twenty-five feet.

Inlabit Spitzbergen, straits of Davis, coast of New England.

\section{Species.}

3. Delphimus grampus, Hunter, Epaulard des Saintongeois, Orca, Fred. Muller, Fauna Groenlandica. Butkopf, of the Dutch. Grampus, of the English. Delphimus orca, Linn. Gmel. Shaw, Gen. Zool. vol. ii. part 2. pl. 232. Dauphin epaulard, Bonnaterre, Cetolog. p. 22. No. 4. Grampus, Cuv. Regn. Anim. vol. i. p. 279. Dauphis orque, Lacep. Cacholot, of Anderson. Duhamel peches, pl. 9. fig. 1. (Encycl. Cetelog. pl. 12. fig. 1.) Desm. Mamm. p. $51 \%$.

Char. Essent. Body and tail elongated; cranium slightly convex; snout cylindrical and very short; superior jaw rather longer than the inferior, the latter broader than the former; teeth unequal, blunt, conical and recurved at top ; length of the dorsal fin more than one-tenth the total lengtin of the body, and placed towards the middle of the back; blackish colour of the back distinct from the white colour of the belly. Dimensions nearly twenty-five feet.

Inhabit the At antic ocean, as far as the straits of Daris. 
5. Subgenus. Delphinapterus, Lacep.

Head obtuse; snout not prolonged; furnished with a moderate number of teeth, but no dorsal fins.

\section{Species.}

1. Delphinus leucas, Gmel. Whitfish, Anderson Iceland, p. 251. Oranz, Groenland. p. 150. Muller, Prodr. Zool. Dan. p. 50. Delphinus albicans, Otho Fabricius, Faun. Groenl. p. 50. Delphinus pinna in dorso nulla, Briss. Regn. Anim. p. 374. No. 5. Dauphin beluga, Delphinus albicans, Bonnaterre, Encycl. Cetologie, p. 24. No. 6. Delphinapterus beluga, Lacep. Beluga, Shaw. Huitfish or Epaulard blanc, of the Danes.

Char. Essent. Head obtuse; teeth short, blunt, nine in number on each side of both jaws; the superior directed obliquely backwards; a small angular eminence takes the place of the dorsal fin; body, tail and fins, of a uniform yellowish-white colour.

Dimensions, from twelve to eighteen feet.

Inhabit the north seas, but particularly the straits of Davis.

6. Subgenus. Heterodon, Blainville.

Monodon, Fabr. Bonnaterre. Hiperoodon and Anarnachus, Lacep. Uranodon and Ancylodon, Illig. Epiodon, Rafin. 
Teeth not numerous, (most frequently two only in one jaw, or none at all;) the lower jaw commonly more voluminous than the upper.

Note.-(The Narwhal, of which they have made a particular genus, might, according to Desmarest, be rigorously placed under this subgenus.)

\section{Species.}

1. Delphinus anarnachus, Desm. Mamm. p. 520. Anarnak, of the Greenlanders, Otho Fabric. Fauna Groenlandica, p. 31. Monodon anarnak, $\boldsymbol{M o}$ nodon spurius, Bonnaterre, Cetolog. p. 11, No. 2.

Char. Essent. Body elongated; two small recurved canine teeth in the upper jaw only; a small blackish coloured dorsal fin.

Dimensions. This is one of the smallest animals of the whole order.

Inhabit the seas of Greenland, and do not approach the shore.

\section{Genus.}

Monodon, Linn. Erxleb. Gmel. Bonnat.

Cerctodon, Briss. Illig.

Diodon, Storr.

Narwhalus, Lacep. Dumèril, Teidm. Cuvier.

-Naruhal. 
CHARACTERS.

Dental formula.-Teeth 2. $\begin{cases}\text { superior 2. } & \left\{\begin{array}{l}\text { Incisor } 2 . \\ \text { Canine } 0 . \\ \text { Molar } 0 .\end{array}\right. \\ \text { inferior 0. } & \left\{\begin{array}{l}\text { Incisor 0. } \\ \text { Canine 0. } \\ \text { Molar } 0 .\end{array}\right.\end{cases}$

One or two large tusks, implanted in the os incisivum, straight, long and pointed, directed in a line with the axis of the body. No other teeth.

General form analogous to that of the Dolphins.

Orifices of the blowing holes united, and situated at the highest part of the back of the head. A longitudinal crest taking the place of the dorsal fin; fins of the flanks of an oval form.

HaBit. These animals, somewhat similar to the Dolphins in their manners, swim in troops, and feed on fish of the genus Pleuronectes, as well as on shells; they attack the Whale, and sometimes inflict mortal wounds with their tusks, when they eat the tongues of their victims.

\section{Species.}

1. Monodon monoceros, Linn. Erxleb. Gmel. Monodon, Artedi, Gen. p. 78. N. 1. Narwhal, oder einhorn, Anderson, Island. p. 225. Muller, Zool. Dan. Prodrom. p. 6. No. 44. Monodon narwhal, Oth. Fabric. Faun. Groendland. p. 29. Narwhal, Bonnaterre, Cetolog. p. 10. Narwhal vulgaire, Lacep. Shaw, Gen. Zool. vol. ii. part 2. pl. 225. 
Home, Comp. Anat. pl. (Encycl. Cetolog. pl. 5. fig. 1, 2, 3.) Vulgo, Licorne de mer, or Sea Unicorn.

\section{Common Narwhal.}

Char. Essent. General form of the body ovoid; length of the head nearly equal to one-fourth that of the body; tusk on the left side commonly solus, the right being seldom developed, grooved spirally, one-half the length of the body; skin of the young animal of a uniform grayish colour on the back, and blackish and marbled in the old; belly white.

Diuensions. From twenty to twenty-two feet, comprising the tusk.

Inhabit the eightieth degree of north latitude, principally on the coast of Iceland, near Davis' Straits, as well as the shores of North America and Greenland.

\section{Species.}

2. Monodon microcephalus,-Desm. Mamm. p. 523. Narwhal microcephale, Narwhalus microcephalus, Lacep. Hist. Nat. des Cetac. 159. pl. 5. fig. 2.

Char. Essent. Body and tail very much elongated; general form nearly conical ; length of the head nearly equal to one-tenth the total length; tusk long, straight, grooved spirally ; skin white, varied with numerous bluish spots. 
Dimensions. Medium length twenty-one or twenty-four feet.

$\mathrm{H}_{\mathrm{ABIT}}$. Swimming with more facility than the common Narwhal.

Inhabit the fortieth degree of north latitude. One was captured near Boston. M. Lacepede thinks that the Narwhals, seen near Davis' Straits, are related to this species.

\section{Species.}

* 3. Monodon andersonianus, Desm. Mamm. p. 523. Narwhal d'Anderson, Lacép. p. 163. Monodon monoceros, Var. Bonnaterre, (Encycl. Cetolog. p. 11.) Willughby, Ichthyol. lib. 2. p. 43.

Char. Essent. Tusk uniform, and without spiral grooves.

Inhabits the North Sea.

Second Division.

Large headed Whales.

The head forming one-third or one-half the total length.

\section{Genus.}

Cachalot, Physeter, Linn. Erxleb. Schreb. Cir. Lacep. Bonnat.

Cetus, Brisson.

Catodon, Linn. Lacep.

Physalis, Lacep. 
Characters. Dental formula. From eighteen to twenty teeth on each side of the lower jaw.

Superior jaw broad, elevated, without corneous laminæ, without teeth, or furnished with small teeth nearly concealed by the gums; inferior jaw elongated, narrow, corresponding to a groove in the upper, and armed with thick and conical teeth entering into corresponding cavities in the opposing jaw.

Blowing holes united, and situated near the end of the upper part of the snout.

A dorsal fin in some species; a mere eminence in others.

Large cavities with cartilaginous septi in the superior region of the head, communicating with various parts of the body by particular canals, and filled with an oil which crystallizes in cooling. (Called commonly adipocere, blanc de baleine, spermaceti.)

The Cachalots inhabit principally the Polar Regions, but are found sometimes in temperate regions; they war with the seals and feed also on crustacea.

\section{Subgenus, Catodon, Lacep.}

Blowing holes situated completely at the end of the upper surface of the snout. No dorsal fin. 


\section{Species.}

1. Physeter macrocephalus, Desm. Mamn. p. 524. Shaw, Gen. Zool. vol. 2. pl. 2. p. 49. pl. 228. Cachalot macrocèphale, Lacep. Hist. Nat. des Cetacèes, pl. 10. fig. 1. Grand cachalot, Bonn. Cetolog. p. 12. No. 1. (Encycl. Cetolog. pl. 6. fig. 1. et pl. 7. fig. 2.)

Char. Essent. Inferior teeth to the number of twenty or twenty-three on each side, recurved and rather pointed at the extremity; small conical teeth, concealed beneath the gum of the upper jaw; tail very narrow and conical; a longitudinal eminence or false fin on the back, above the anus; body blackish beneath, or a slate blue, slightly spotted with white; belly whitish.

Dimensions. Total length forty-five or sixty feet.

Description. For description, see Cetologie of Bonnaterre.

Note.-(According to M. Cuvier, the blowing hole is single but not symmetrical, being directed to the left side. It is said that the left eye is much smaller than the right.)

Inhabit the North Sea.

\section{Species.}

2. Physeter trumpo, Desm. Mamm. p. 524. (Encycl. Cetolog. pl. 8. fig. 1.) Cetus Nova An- 
glia, Briss. Regn. Anim. p. 360. No. 3. Dudley, Philos. Trans. No. 357. Robertson, Trans. Philos. vol. 60. Blunt headed, Penn. Zool. Britan. vol. 3. p. 61. Physeter macrocephalus, Var. $\gamma$. Linn. Gmel. Cachalot trumpo, Bonnaterre, Cetolog. p. 14, No. 3. Lacep. Hist. Nat. des Cetacèes, p. 210, pl. 10. fig. 2.

Char. Essent. Head longer than the body; inferior teeth, straight and pointed, eighteen on each side, penetrating as many alveoles on the opposing jaw; body and tail elongated; a rounded eminence rather beyond the origin of the tail.

Dinensions. This species attains to fifty feet in length; twenty-seven feet in circumference.

(M. Cuvier is of the opinion that this species is the same as the preceding.)

Inhabiting the coasts of Bermuda and North America.

Several other species are noticed by Desmarest, Mamm. p. 525 and 526, as frequenting the northern Atlantic coasts, viz. 1. Physeter catodon; 2 . $P$. cylindricus; 3 . P. microps; 4. P. othodon; 5. P. mular; but as there exists some doubt as to their identity, we have briefly noticed them, and refer to Bonn. Cetolog. Loc. Cit. for further detail.

\section{Genus.}

Balana, Willughby, Rai. Artedi, Linn. Briss. Klein. Erxleb. Gmel. Bonn. Lacep. Cuv. Illig. Physeter, Willugh. 
Balcnoptera, Lacep.

Superior jaw carinate, or in form of an inverted roof, furnished on each side with transverse corneous laminæ, thin, serrated and fimbriated at their borders.

Blowing holes separate, and placed towards the middle of the upper part of the head; a dorsal fin in some species; nodosities or dorsal prominences in others; cæcum short.

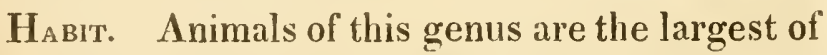
the known inhabitants of the globe, feeding on fish, molusca, worms and zoophites. They have no reservoir filled with adipocere like the Cachalots, and do not like these produce ambergris, but the oil which they furnish in abundance, renders them an object of great value.

Inhabit the northern seas, occasionally visiting: more temperate latitudes.

\section{Subgenus. Balana, Lacep.}

No dorsal fin.

Species.

1. Balana mysticetus, Linn. Erxleb. Gmel. Balana major, Sibbald. Balana vulgaris groenlandica, Briss. Regn. Anim. p. 347, N. 1. Oth. Fabr. Faun. Groenland. 32. Baleine franche, Bonnat. Cetolog. p. i. N. 1. Lacep. Hist. Nat. des Cetacées. pl. 1. fig. 1. (Encycl. Cetolog. pl. 2. fig. 1.) 
Char. Essent. Body thick and short; tail short; no prominence on the back; upper jaw furnished with about seven hundred transverse corneous plates.

Dimensions. Total length from fifty to ninety feet.

For description see Bonnaterre, loc. cit. The size of this species has been overrated at a hundred feet. Of three hundred and twenty-two individuals measured by Captain Scoresby, not one exceeded sixty feet. The average size is fifty feet.

Inhabit the Atlantic Ocean, particularly the Polar Sea, in the neighbourhood of Greenland. According to Scoresby, feeding on actinia, medusa, snails, crabs, shrimps, \&c.

\section{Species.}

2. Balana glacialis, Klein, Miss. Pisc. 2. p. 12. Balana islandica, bipinnis ex nigro candicans, dorso levi, Briss. Regn. Anim. p. 350. No. 2. Nord-caper, Anderson, Island. p. 219. Baleine nord-caper, Bonn. Encycl. Cetolog. p. 3. No. 2.

Balana mysticetus, var. $\beta$. Gmel.

Baleine nord-caper, Lacep. p. 103. pl. 2 and 3.

Char. Essent. Inferior jaw rounded, very high and broad; body and tail elongated; no prominence on the back; general colour more or less clear gray; beneath the head a large oval surface, of a shining white appearance, with some blackish and grayish spots around it and in its centre. 


\section{Description. Vid. Bonnaterre, loc. cit.}

HaBIT. When this species swims on the surface of the water, all parts of the body are immerged, excepting the top of the back and blowing holes; they are very active and fierce, which renders them very difficult to capture.

Inhabit that part of the northern Atlantic situated between Spitzbergen, Norwegia, and Iceland, the seas of Greenland.

\section{Species.}

3. Balana nodosa, Bonnaterre, Cetologie, p. 5. No. 4. Briss. Regn. Anim. p. 351. No. 3. Plokfisch, Anderson, Island. p. 224. Crantz, Groenland. p. 146. Dudley Philos. Trans. No. 387. p. 256. Art. 2. Balana gibbosa, Var. B. (Nova Angliæ,) Gmel. Baleine noueuse, Lacep. Hist. des Cetacèes, p. 3.

Char. Essent. A prominence on the back, slightly inclined backwards, and situated near the tail; pectoral fins. white, very long and distant from the end of the snout. Described by Bonnaterre.

Frequent the coast of New England.

\section{Species.}

4. Balana gibbosa, Bonnaterre Cetolog. Balana gibbis, vel nodis sex. Balana mara, Klein. Miss. pisc. 2. p. 13. ? Baleine á six bosses, Briss. 
Regn. Anim. p. 351. No. 4. Crantz. Groenl. p. 146. Muller. Balleine bossue, Lacep. Erxleb.

Char. Essent. Five or six protuberances on the back, near the tail; corneous laminæ white. Described by Bonnaterre, loc. cit.

Frequents the seas in the vicinity of New England.

2. Subgenus. Balanoptera, Lacep.

Possessed of corneous plates, and a dorsal fin.

Species.

1. Balcena gibbar, Bonnat. Cetolog. Finfisch, Marten's, Spitzb." p. 125. p. 2. Balana fistula duplici in medio capite, tubero pinniformi in extremo dorso, Artedi, Gen. 77. Syn. 107. Baleine gibbar, Rondelet, Hist. des poiss. 1. part. liv. 16 . ch. 8. Blana tripinnis, ventre levi, Briss. Regn. Anim. p. 352. No. 5. Balana physalus, Linn. Erxleb. Gmel. Baleinoptère gibbar, Lacep. Hist. des Cetacèes, p. 114. pl. 1. fig. 2.

Char. Essent. Jaws pointed and equally prolonged; corneous plates short, of a bluish colour; no fold beneath the throat or under the belly; body brown above, white beneath.

Dimersions. Length of the body equal that of the $\boldsymbol{B}$. mysticetus, circumference much less. Described by Bonnaterre, loc. cit.

Frequent the frozen Arctic ocean, particularly 
near to Greenland. They are also found in the northern Atlantic ocean; they descend even to the thirtieth degree. Martin observed one of this species in the straits of Gibraltar, in 1673.

\section{Species.}

2. Balana boops, Linn. Syst. Nat. edit. 10. Erxleb. Gmel. Jubartes, Klein, Miss. pisc. 2. p. 13. Jupiter-fisch, Anderson, Island. p. 220. $B a$ leine à museau pointù, balana tripinnis ventre rugoso, rostro acuto, Briss. Regn. Anim. p. 355. No. \%. Baleinoptère jubarte, Lacep. Hist. Nat. des Cetacèes. p. 120. pl. 4. fig. 1. (Encycl. Cetolog. pl. 3. fig. 2.)

Char. Essent. Nucha elevated and rounded: snout prolonged, broad and rather rounded; longitudinal folds beneath the throat and belly; tuberosities nearly hemispherical, situated anterior to the blowing holes; dorsal fin curved backwards.

Dinensions. Total length, from fifty-one to fifty-four feet.

(For description, vid. Bonnaterre, loc. cit.) Its range is principally about the Greenland seas; and Iceland. According to Lacepede, they visit both hemispheres. They pass the winter in the high seas, and visit the shores during summer.

Species.

3. Balana rostrata, Hunter. Trans. Philos. 
Soc. 1787. Oth. Fred. Muller, Faun. Groenland. p. 40. Baleine à bec, Bonn. Cetolog. p. 8. No. 8. Balanoptera acuto-rostrata, Lacep. Hist. Nat. des Cetacées, p. 134. pl. 4. fig. 2. (Encycl. Cetolog. pl. 4. fig. 1.)

Char. Essent. Both jaws pointed, the upper shorter and narrower than the lower; longitudinal folds beneath the throat and belly; corneous plates short and whitish; body above of a deep black, beneath whitish, shaded with blackish spots.

Dimensions. Total length twenty-seven or twenty-eight feet.

(For description vid. Bonnaterre.)

M. Cuvier thinks this species is not clearly ascertained to be different from the $B$. boops.

Frequent the northern Atlantic, the shores of both continents. 



\section{ADDENDA.}

Messris. Lewis and Clark, in the history of their Expedition up the Missouri, have described, with their usual accuracy, several new animals, which have neither received scientific names nor assumed that station in the systems to which they properly belong. The first of these to which we allude, are three species of the genus Arctomys, two of which inhabit the great plains of the Columbia river, from the Rocky Mountains to the Pacific Ocean; the other, the plains of Missouri.

Mr. Rafinesque has attempted an arrangement of these animals, by constructing from them a new genus, which he names "Anisonyx," and to which he assigns the following characters._-" Teeth like those of Squirrels; no cheek-pouches; five clawed toes to all the feet, the two internal of which on the fore feet very short, the three others long, with very sharp nails; tail distichous like that of Squirrels. (This genus differs from the Marmots and the Squirrels in the number and form of the fingers.")

In the above description of $M r$. Rafinesque;

* Vid. American Monthly Magazine, vol, ii. p. 45. 1817 
we detect false translation and interpolation, which are noted by italics. On examination of the descriptions of these animals by Messrs. Lewis and Clark, they will be found to be generically allied to the Marmots.

\section{Genus.}

Arctomys.

\section{Species.}

1. Arctomys brachyura.

Anisonyx brachyura, Rafinesque, Amer. Mon. Magaz. vol. ii. p. 45.

Burrowing Squirrel, Lewis and Clark's Exped. up the Missouri, vol. ii. p. 173.

Short tailed Marmot.

Char. Essent. Colour cinereus-brown above, a light brick-red beneath; tail flat, reddish, subdistichous, one-seventh of the total length.

Dinensions. Total length two feet five inches, including the tail, the latter being two inches and a half long.

Description. The neck and legs are short; the ears are likewise short, obtusely pointed, and lie close to the head; the aperture larger than will generally be found among burrowing animais; the eyes are of a moderate size, the pupil black, and the iris of a dark sooty-brown; the whiskers are full, long and black; the teeth, and, indeed, the whole contour, resemble those of the Squirrel: 
each foot has five toes; the two inner ones (thumbs) of the fore feet are remarkably short, and are equipped with blunt nails; the remaining toes (nails) on the front feet are long, black, slightly curved, and sharply pointed; the hair of the tail is thickly inserted on the sides only, which gives it a flat appearance, and a long oval form; the tips of the hair forming the outer edges of the tail are white, the other extremity of a fox-red; the under part of the tail resembles an iron-gray, the upper is of a reddish-brown; the lower part of the jaws, the under part of the neck, legs, and feet, from the body and belly downwards, are of a light brick-red; the nose and eyes are of a darker shade of the same colour; the upper part of the head, neck and body, are of a curious brown-gray, with a slight tinge of brick-red; the longer hairs of these parts are of a reddish-white colour at their extremities, and falling together, give this animal a speckled appearance.

HABIT. These animals form in large companies like those on the Missouri, (Arctomys ludoviciani, Ord,) occupying, with their burrows, sometimes two hundred acres of land; the burrows are separate, and each possesses, perhaps, ten or twelve of these inhabitants. There is a little mound in front of the hole, formed of the earth thrown out of the burrow, and frequently there are three or four distinct holes, forming one burrow, with these entrances around the base of these little mounds. 
These mounds, sometimes about two feet in height, and four in diameter, are occupied as watch towers by the inhabitants of these little communities. The Squirrels, one or more, are irregularly distributed on the tract they thus occupy, at the distance of ten, twenty, or sometimes from thirty to forty yards. When any one approaches, they make a shrill whistling sound, somewhat resembling tweet, tweet, tweet, the signal for their party to take the alarm, and to retire into their intrenchments. They feed on the roots of grass, \&c.

Inhabit the plains of Columbia. (Lewis and Clark.)

\section{Species.}

\section{Arctomys latrans, (nob.)}

Barking Squirrel, Lewis and Clark's Exped. up the Missouri, vol. ii. p. 175.

Char. Essent. Colour a uniform brick-red, lighter beneath; cheeks furnished with pouches; a few long hairs are inserted oll each jaw, and directly over the eyes.

Dimensions. From the extremity of the nose to the end of the tail, one foot five inches; tail, four inches; weighing about three pounds.

Description. Colour of a uniform brick-red, the former predominating; the under side of the neck and belly are lighter than the other parts of the body; the legs are short, and the breast and shoulders wide; the head is stout and muscular, 
and terminates more bluntly, wider, and flatter than that of the common Squirrel; the nose is armed with whiskers on each side, and a few long hairs are inserted on each jaw, and directly over the eyes; the eye is small and black; each foot has five toes, and the two outer ones are much shorter than those in the centre; the two inner toes of the fore feet are long, sharp, and well adapted to digging and scratching.

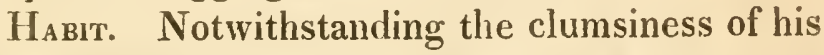
form, he is remarkably active, and he burrows in the ground with great rapidity. These animals burrow and reside in their little subterraneous villages like the burrowing Squirrel. To these apartments, although six or eight usually associate together, there is but one entrance. "They are of great depth, and Captain Lewis once pursued one to the depth of ten feet, and did not reach the end of the burrow. They occupy, in this manner, several hundred acres of ground, and when at rest, their position is generally erect on their hinder feet and rump; they sit with much confidence, and bark at the intruder as he approaches, with a fretful and harmless intrepidity. The note resembles that of the little toy-dog; the yelps are quick, in angry succession, attended by rapid and convulsive motions, as if they were determined to sally forth in defence of their freehold. They feed on the grass of their village, the limits of which they never venture to exceed. As soon 
as the frost commences, they shut themselves up in their caverns, and continue until the spring opens. The flesh of this animal is not unpleasant to the taste.

Inhabit the plains of the Missouri. (Lewis and Clark.)

\section{Species.}

3. Arctomys rufa.*

Sewellel, of the Indians of the western coast, Lewis and Clark's Exped. up the Missouri, vol. ii. p. 176.

Anisonyx rufa, Rafinesque, Amer. Mon. Magaz. who has confounded it with the preceding species.

Char. Essent. General colour reddish-brown; fur short, thick and silky; ears short, thin and pointed, covered with hair.

Dimensions. 'Total length, from fourteen to eighteen inches (of the dressed skin, from which the tail is always separated by the Indians.)

Description. Ears short, thin, and pointed, and covered with a fine short hair, of a uniform reddishbrown; the bottom or the base of the long hairs, which exceed the fur but little in length, as well as the fur itself, are of a dark colour next the skin for two-thirds the length of this animal; the fur and hair are very fine, short, thickly set, and silky; the ends of the fur and tip of the hair are of a reddish-brown, and that colour predominates in the usual appearance of the animal. 
Inhabit the woody plains of Columbia, more abundant in the neighbourhood of the Great Falls and Rapids of the Columbia than on the sea coast.

Captain Lewis offered considerable rewards to the Indians, but was never able to procure one of these animals alive.

Meles?

\section{Genus.}

\section{Species.}

1. Meles jeffersonii, (Nobis.)

Braro, of the French hunters, Lewis and Clark's Exped. up the Missouri, vol. ii. p. $17 \%$.

Badger of Columbia.

Char. Essent. Body proportionably long, fore legs large, muscular, formed like those of the turnspit-dog; all the legs short; breast and shoulders broad; neck short; mouth wide; whiskers placed in four points on each side of the nose.

Dinensions. Body long in proportion to its thickness; tail four inches long; the whole animal weighing from fourteen to eighteen pounds.

Description. The fore legs are remarkably large, short, and muscular; neck short; mouth wide, and furnished with straight teeth, both above and below, with four sharp, straight, pointed tusks, two in the upper and two in the lower jaw; the eyes are black and small; whiskers placed in four points on each side near the nose, and on the jaws near the opening of the mouth; 
the ears short, wide, and oppressed, as if a part had been amputated; the tail is four inches in length, the hair of which is longest at the point of the junction with the body, and growing shorter until it ends in an acute point; the hairs of the body are much shorter on the sides and rump than those on any other part, which gives the body an apparent flatness, particularly when the animal rests upon his belly; the hair is upwards of three inches in length, especially on the rump, where it extends so far towards the point of the tail that it conceals the shape of that part, and gives to the whole of the hinder parts of the body the appearance of a right angle triangle, of which the point of the tail forms an acute angle; the small quantity of coarse fur intermixed with the hair is of a reddish-pale yellow.

Haвiт. They burrow in hard grounds with surprising ease and dexterity, and will cover themselves in a very few moments; they have long fixed nails on each foot, those on the fore feet are much the longest, and one of those on each hind foot is double.

Inhabit the open plains of Columbia, sometimes those of the Missouri, and are sometimes found in the woods.

\section{Genus.}

Lepus.

Species.

Lepus virginianus, Var.? (Nobis.) 
Varying hare, Lewis and Clark's Expedition up the Missouri, vol. ii. p. 179.

Char. Essent. Colour, plumbeous above, white beneath, during the summer; of a pure white in winter; tips of the ears, black or reddish-brown at all seasons; body covered with fine, close fur; tail round, bluntly pointed.

Dinensions. Body smaller and longer in proportion than that of the common rabbit, (L. americanus, weighing from seven to eleven pounds.

Description. The eye is large and prominent, the pupil of a deep sea-green, occupying one third of the diameter of the eye; the iris is of a bright yellowish and silver colour; the ears are placed far back, and very near each other, which the animal can, with surprising ease and quickness, dilate and throw forwards, or contract and hold upon his back at pleasure; the head, neck, back, shoulders, thighs and outer part of the legs are of a lead colour; the sides as they approach the belly, become gradually more white; the belly, breast, and inner part of the legs and thighs are white, with a light shade of lead colour; the tail is round and bluntly pointed, covered with white, soft, fine fur, not quite so long as on the other parts of the body; the body is covered with deep, fine, soft, close fur.

'The colours here described, are those which the animal assumes from the middle of April to 
the middle of November; the rest of the year he is pure white, except the black and reddishbrown of the ears, which never change. A few reddish spots are sometimes intermixed with the white, at this season, (February 26, 1806, on their heads and the upper part of their necks and shoulders; the body of the animal is smaller and longer in proportion to its height than in the rabbit. When he runs he conveys his tail straight belind, in the direction of the body; he appears to run and bound with surprising agility and ease. He is extremely fleet, and never burrows or takes shelter in the ground when pursued. His teeth are like those of the rabbit, as is also his upper lip, which is divided as high as the nose.

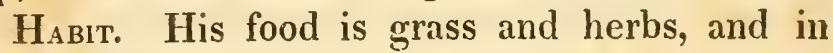
winter he feeds much on the bark of several aromatic herbs growing on the plains. Captain Lewis measured the leaps of this animal, and found them commonly from eighteen to twenty-one feet; they are generally found separate, and are never seen to associate in greater numbers than two or three.

Inhabit the plains of Columbia, on the western side of the Rocky mountains, on the eastward of these mountains they inhabit the plains of the Missouri. (Lewis and Clark.)

\section{Genus.}

\section{Canis.}

The following notice of the North American 
Indian $\log \mathrm{s}$, is extracted from the manuscript notes of the late Mr. William Bartram, one of the earilest naturalists of this country.

"The Indian dogs which I have observed among the south-western nations, are generally black, pied-black and white, and some of other colours, but nost commonly black; having sharp pointed, erect ears; the muzzle long and pointed, much like the wolf, but their tail is not so bushy, and they are not so noisy as our dogs; they are slender and of various sizes, some not larger than the for, and resembling them in shape and appearance; probably a spurious race engendered between the wolf and fox; displaying the sly and subtle look of these animals. They are fierce, watchful, and faithful to their keepers, but have a peculiar antipathy to white people.

"The Nerfoundland dog is undoubtedly native of North America, and seem to be of the same race, or derived from the Greenland dogs. They are much larger than the Indian dog above noticed, being as large or larger than the wolf or mastiff, and are remarkably different in shape, being more clumsily formed; their limbs strong and muscular; their ears not so erect and peaked, being more like those of the bear, as is also their muzzle; their lips are not so pendant, infolded, or tumid, as those of the Spaniel or European logs. Their tail is rery short, like that of the bear; 
they are variously coloured and differently coated; some being woolly or shagged; others have fine, short hair, a little curled, which kind are esteemed the best. They are remarkable for their sagacity, watchfulness, and fidelity." 


\section{INDEX.}

\begin{tabular}{|c|c|c|c|}
\hline A. & & Bos americanus, & 268 \\
\hline American race, & 13 & Bufficlo, & ib. \\
\hline Aquatic slrew, & 32 & Bos bombifrons, & 271 \\
\hline American Mole, & 43 & latifions, & 273 \\
\hline American Bear, & 51 & Broad-headed Fossil Ox, & b. \\
\hline American Badger, & 57 & Balæna, & 95 \\
\hline Atalapha, & 21 & mysticetus, & 96 \\
\hline Arvicola, & 134 & glacialis, & 97 \\
\hline amphibius, & ib. & nodosa, & 98 \\
\hline xanthognatus, & 136 & gibbosa, & ; \\
\hline palustris, & ib. & Balinoptera, & 99 \\
\hline hortensis, & 138 & Balæna gibbar, & \\
\hline floridanus, & 41 & boops & 300 \\
\hline $\begin{array}{l}\text { pennsylvanica, } \\
\text { urctoms }\end{array}$ & 44 & rostrata & \\
\hline Arctomys, & 157 & Burrowing Squirrel, (adden.) & 4 \\
\hline $\begin{array}{l}\text { monax, } \\
\text { empetia, }\end{array}$ & 158 & & \\
\hline $\begin{array}{l}\text { empetia, } \\
\text { ludoviciani, }\end{array}$ & 160 & 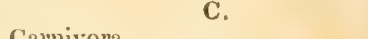 & \\
\hline $\begin{array}{l}\text { ludovicians, } \\
\text { tivideccmlineata, }\end{array}$ & 164 & Cheiroptera, & \\
\hline franklinii, & 166 & Canada scalops, & 2 \\
\hline lichardsonii, & 168 & Condylıu'a, & \\
\hline pruinosa, & 169 & cristata, & \\
\hline parryii, & 170 & Canis, & \\
\hline brachyura, (adden.) & 304 & familiaris, & 5 \\
\hline latrans, (adden.) & 306 & Iupus, & 79 \\
\hline mufa, (adden.) & 308 & lycaon, & 2 \\
\hline American rabbit, & 193 & latrans, & 83 \\
\hline Antelope, & 248 & nubilus, & \\
\hline Antilocapra, & 249 & vulpes, & \\
\hline Antilope amcricana, & 250 & alopex, & \\
\hline Addenda, & 303 & crucigera, & \\
\hline Anisonyx brachyura, & 3 & argentatus, & \\
\hline American Dogs, (adden.). & 3 & decussatus, & \\
\hline Bear, & 45 & $\begin{array}{l}\text { irginianus, } \\
\text { fulvus, }\end{array}$ & ib. \\
\hline Black Bear, & 51 & cinereo-argentatus, & \\
\hline Badger, & 56 & velox, & \\
\hline Black IVolf, & 82 & lagopus, & ? \\
\hline Brown Bear, & 46 & Common Fox, & \\
\hline Black Rat, & 148 & Cat, & 93 \\
\hline Black Squirrel, & 177 & Cougar, & 9 \\
\hline Big-bone-lick, & 214 & Canada Lynx, & \\
\hline Bos, & 267 & Chat servier. & 9 \\
\hline
\end{tabular}




\section{6}

Chat sauvage,

Carnivora pinnapedia,

Castor,

Chick-a-ree,

Cervus,

alces,

tarandus,

canadensis,

virginianus,

macrotis,

americanus,

Capra,

montana,

Ceta,

Cetacia herbivora,

Cachalot,

Catodon,

D.

Dog,

varieties of,

Dusky Wolf,

Didelphis,

Dipus,

Dicotyles,

Deer,

Delphinus,

Dolphin,

Delphinus coronatus,

Delphinis delphis,

Delphinus canadensis,

Delphinis phocæna, gladiator,

Delphinus grampus,

Delphinapterus,

Delphinus leucas, anarnachus,

E.

Ermine,

Edentata,

Eleplıas,

primogenius,

F.

Fisher Weasel,

Fox,

Felis,

concolor,

onci,

pardalis,
INDEX.

102 Felis canadensis, 98

ib. rufa, 99

122 fasciata, 100

185 montana, 101

227 catus, 102

229 aurea, 101

232 Fiber, 131

236 Florida Rat, 141

238 Fox Squirrel, 175

243 Flying Squirrel, 187

24.5 Fossll Elk, $\quad 245$

252 Ox, 271

253 T'apir, 223

274 Elephant, 207

275 Mastodon, 211

$292 \quad$ Megatherium, 200

293 Megalonyx, 201

Grizly Bcar, $\quad 48$

Gulaire, $\quad 51$

\begin{tabular}{r|lr}
84 & Gulo, & 59 \\
116 & Gray Fox, & 89
\end{tabular}

119 Glires, 121

155 Gnawers, $\quad 121,122$

219 Geonys, 151

227 cincreus, 153

282 Gerbillus, 155

ib. canadensis, ib.

283 labradorius, 156

284 Ground-Hog, 158

285 Gray Amelican Marmot, 167

286 Gray Arctic Marmot, 170

ib. Gray Squirel, 173

287 Goat, 252

288

ib.

289

Harp Seul,

11

109

169

189

190

192

218

lieterodon, 288

86 Introduction, 1

93 Inscctivora, 24

94. Isatis Fox, 92

95 Iaguar, 95

96 Ierboa, 155 
I.

Leinmus,

Lutra, hudsonius,

brasiliensis, marina,

Long-tailed Mole,

Lotor,

Lynx,

aureus,

fasciata,

montana,

du Mississippi,

Lepus,

americanus,

glacialis,

Lamantin, virginianus,

Mussaraigne,

II.

Mole cominon,

Mole,

Mustela,

Vulgaris,

Erminea,

Lutreocephala,

Minx, Zibellina,

Martin,

Melanorhyncus,

Martes,

Martin,

Mephitis,

Mephitis americana,

Mustela americana,

Mustela lutris,

Mountain Cat,

Manatus,

Morse,

Marsupialia,

Musk Rat,

Meadow Mouse,

Marsh Campagnol,

Mus floridanus,

Meadow Mouse,

Mus,

Mus rattus,

Mus syliaticus,

Mus musculus,

Marmot,

Megatherium,

72

ib.

38

53

Manatus,

Monodon,

275

Monodon monoceros, 290

Monodon microcephalus, 291

Monodon andersonianus, 292

Northern Gluttor

N.

New York Bat, 20

Narwhal, O.

Otter,

Ocelot,

Otaria,

(n)

1

119

Osteopera, 126

Ostcopera platycephala, $\quad 126$

Ondatra, 131

Ovis, $\quad 258$

Ovis ammon, $\quad 259$

Ovibos, 264

Ovibos moschatus, $\quad 264$

P

Primates,

Plecotus,

Prochilus,

Plantigrada,

Polar Bear,

P.

Procyon,

Pekan Weasel,

l'ine Martin,

Pole Cat,

Putois,

148 Pantlier,

119 Prairie Wolf,

149 Phoca,

157 Pachydermata,

199 ( Proboscidea, 


\section{8}

Phocæna,

Physeter macrocephalus, Physeter trumpo,

R.

Rhinopoma,

Red Bat of Pennsylvania,

Raccoon,

Red Fox,

Radiated Mole,

Rosmarus,

Rosores,

Rattus,

Rytina,

S.

Saccoptiryx,

Scalops,

Sorex,

Star-nosed Mole,

Skunk,

Spotted Mountain Cat,

Sable Weasel,

Sea Otter,

Schrew,

Sea Lion,

Sea Calf,

Sarrigue,

Salamander,

Sciurus,

cinereus,

capistratus,

rufiventer,

niger,

magnicaudatus, quadrivittatus, lateralis,
INDEX。

285 : Sciurus grammurus, 182

294 striatus, 183

294 hudsonius, 185

Sus, $\quad 217$ scrofa, $\quad 218$

Sirenia, 275

Sea-Cow, ib.

stellerus, $\quad 278$

89 borealis, 279

37

114

121 Tawny American Marmot, 168

147 Tardigrada, 199

278 Tapirus, 222

Tapir, ib.

Trichechus, $\quad 275$

22 Manatus latirostris, 27

30

ib. Vespertilio, $\quad$ V. 18

70 Ursus, 45

96 arctos, 46

64 cinereus, 48

72 ferox, ib.

25 americanus, 51

106 maritimus, ib.

107 lotor, 54

119 gulo, 60

153 marinus, 112

172

173 W.

175 Wolverine, 60

176 Wolf, 79

177 Wild Cat, 101

178 Water Rat, 135

180 Whales, proper, 281

181 White Dolphin of Canada, 285

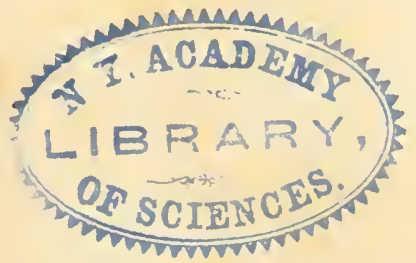




\section{LIST OF SUBSCRIBERS.}

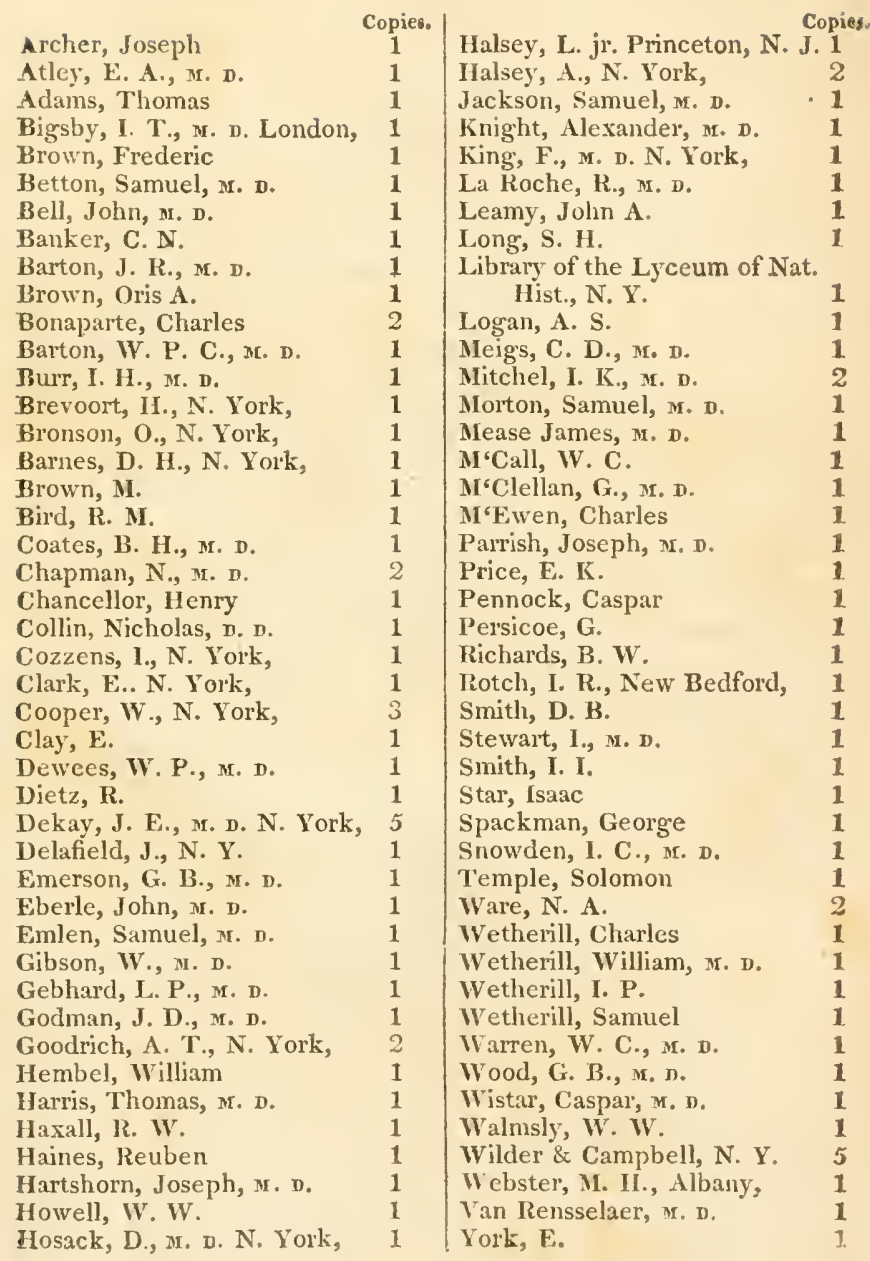




\section{ERRA'TA.}

IN detailing the bahits of the American Pole-Cat, (Mephitis, Cuv.) vid. p. 69, we have stated on the authority of Professor $K a l m^{*}$ and others, that this animal wets its tail with the fetid liquor of the anal glands, in order to sprinkle it on its adversaries; we have since been credibly informed that this is a vulgar error. The Pole-Cat is naturally a very clean animal, and never intentionally soils itself with its own excretions; on the contrary, when pursued, these animals invariably turn their tail over their back, invert the anus in a slight degree, and squirt the offensive liquor to the distance of several yards; this fluid, besides its extremely offensive odour, possesses the property of excoriating the skin, and producing violent inflammation when it strikes the eyes.

Page 201, line 23 et 27, for Megalonix read Megalonyx.

* Vid. Kalm's Travels in North America, vol. i. p. 274. 







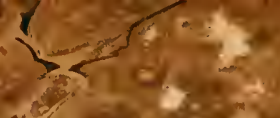

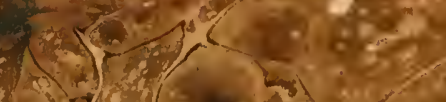

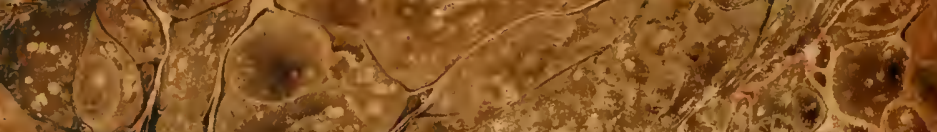

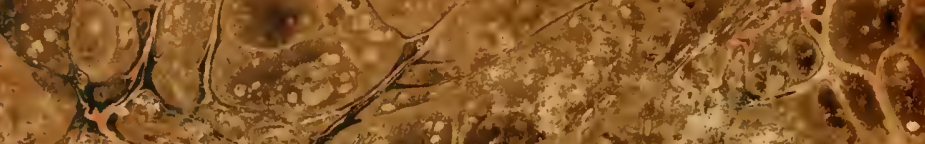

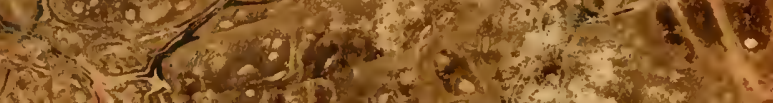

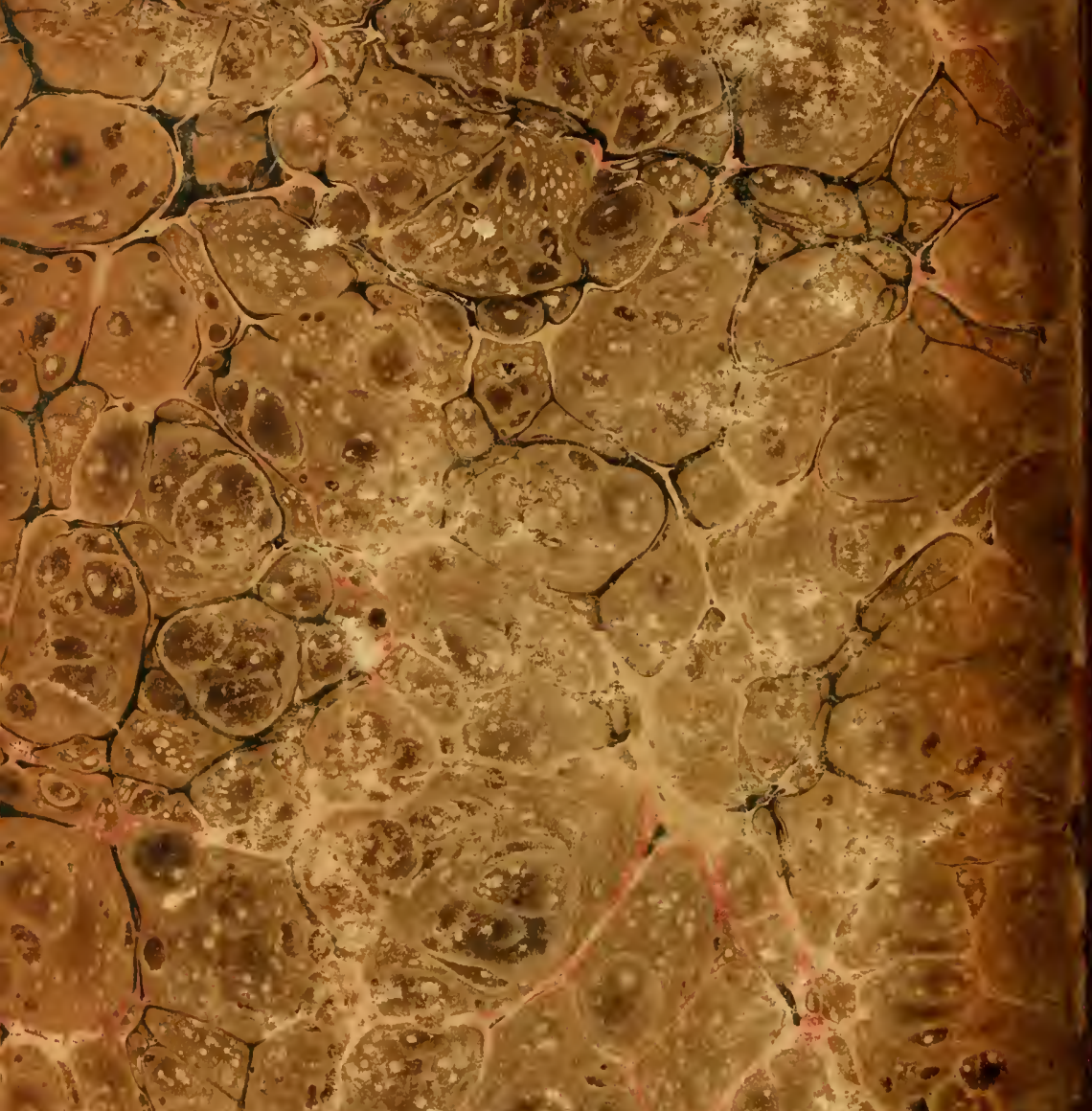

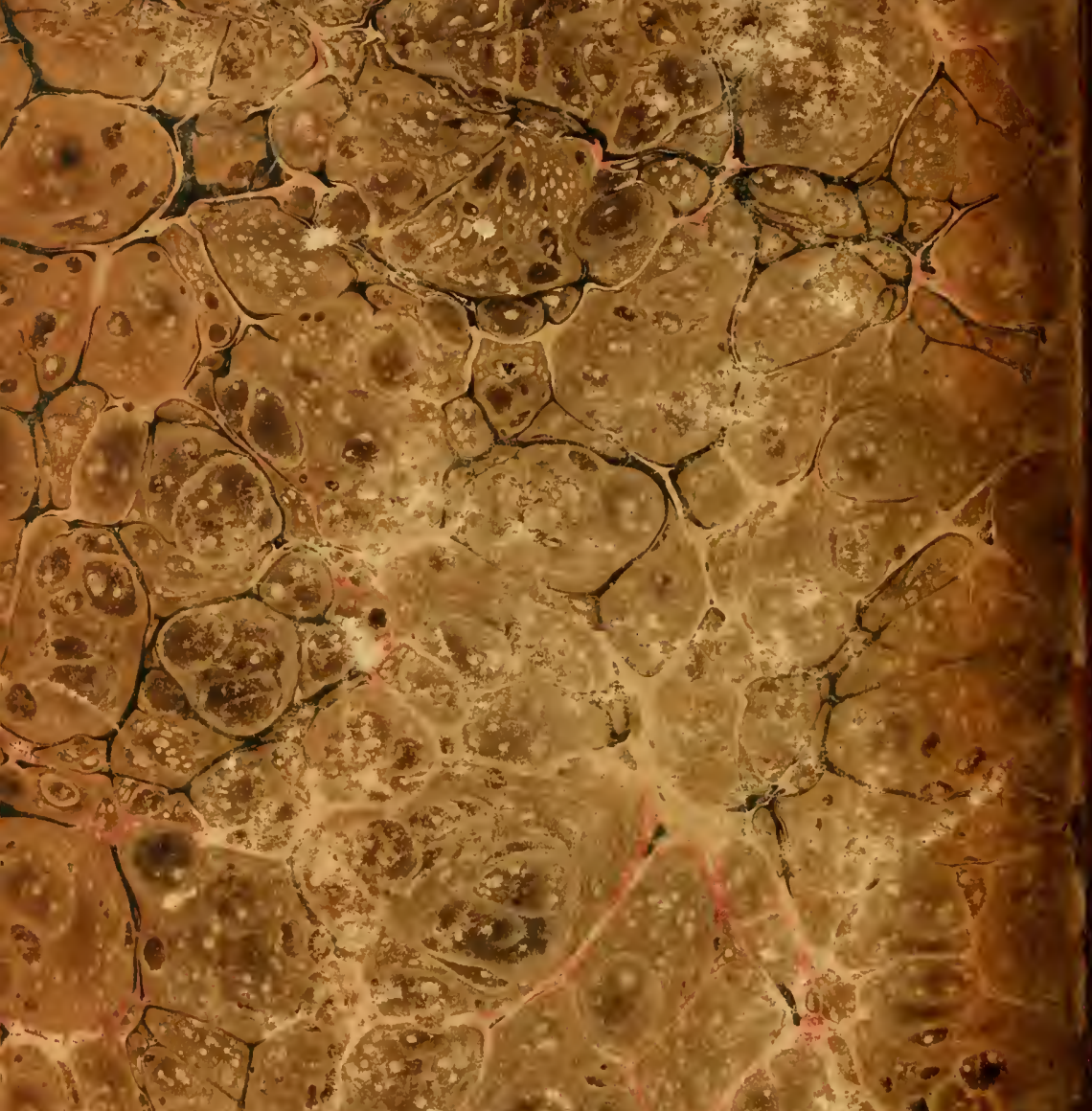

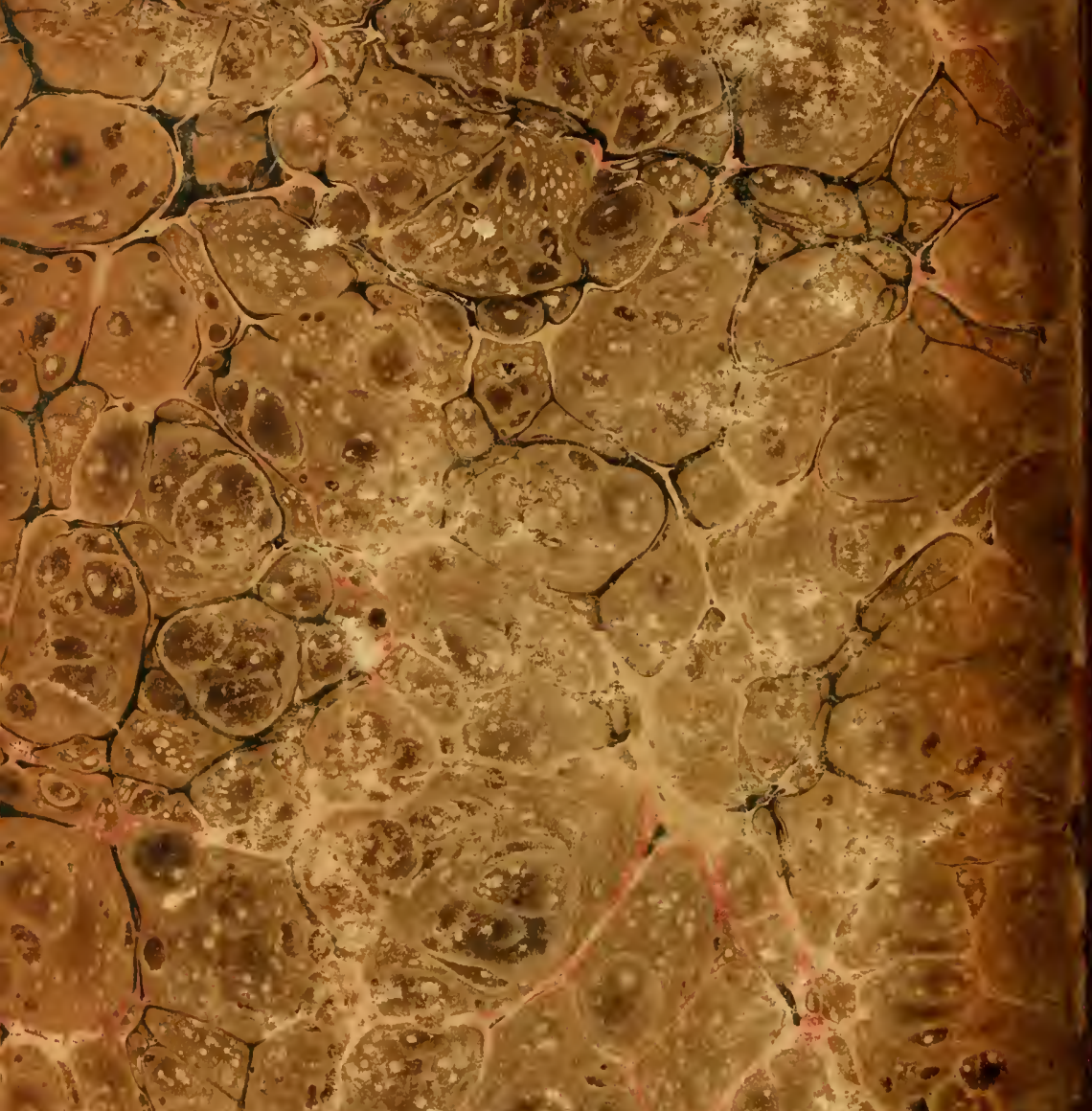

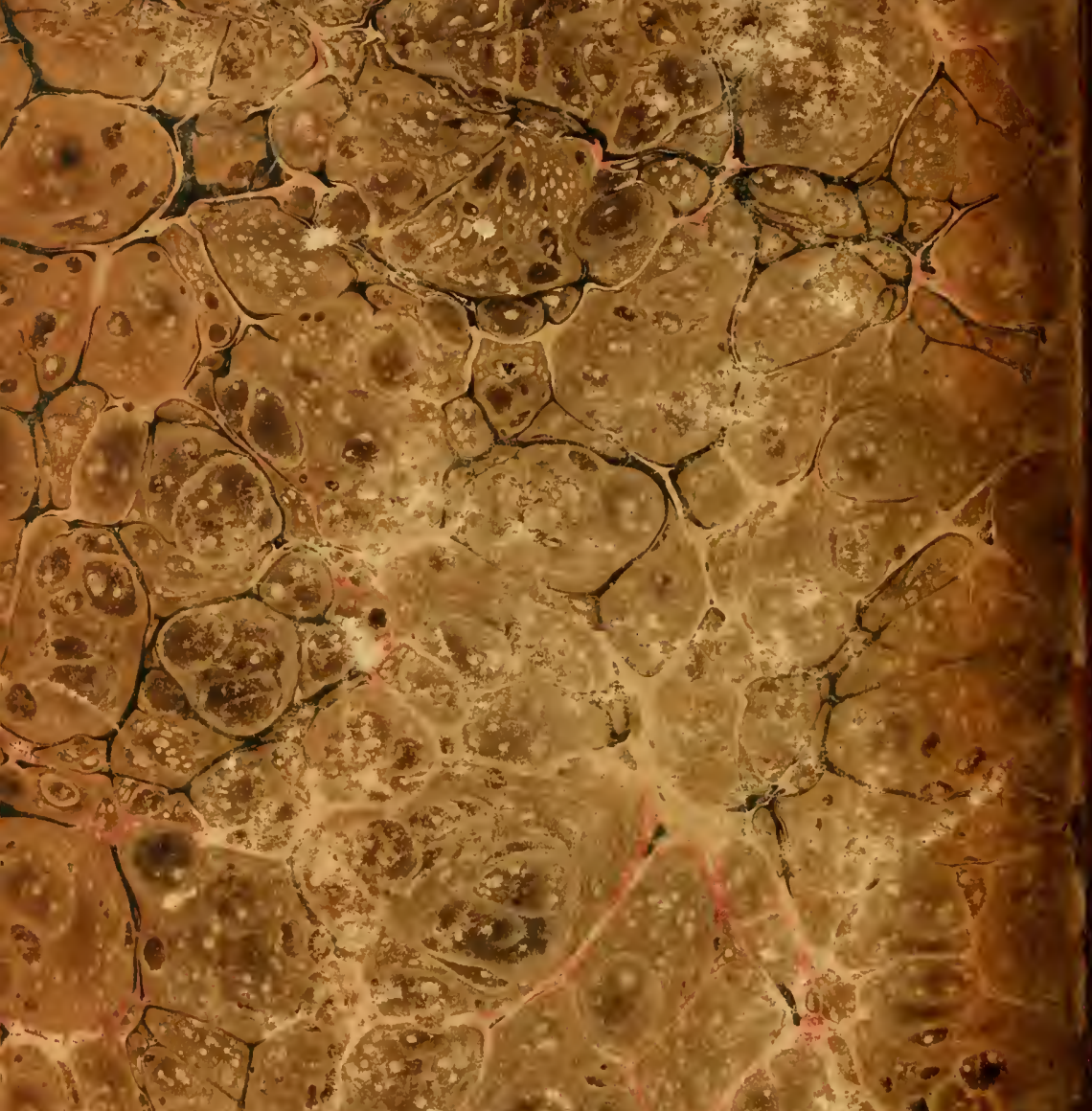

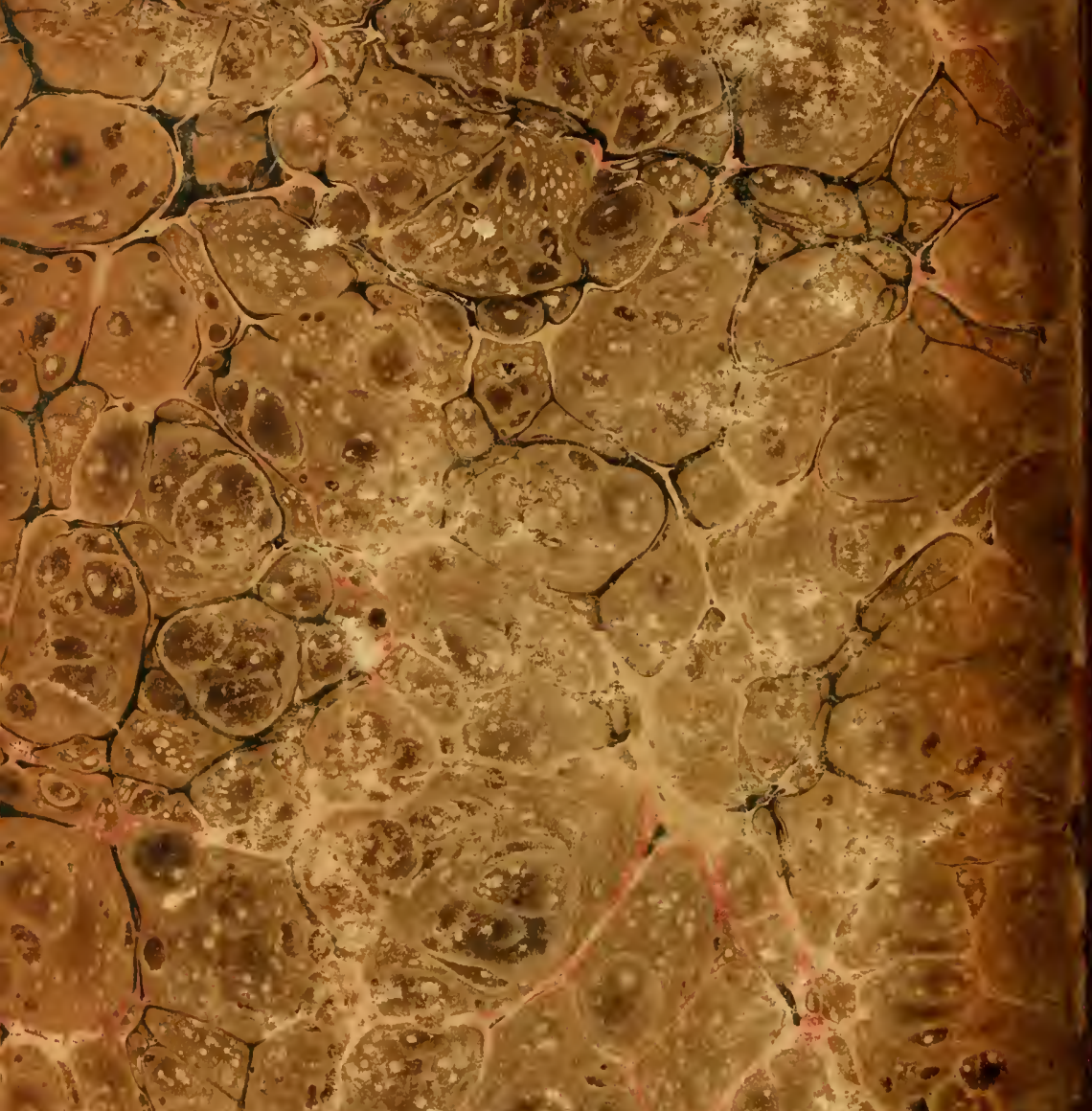

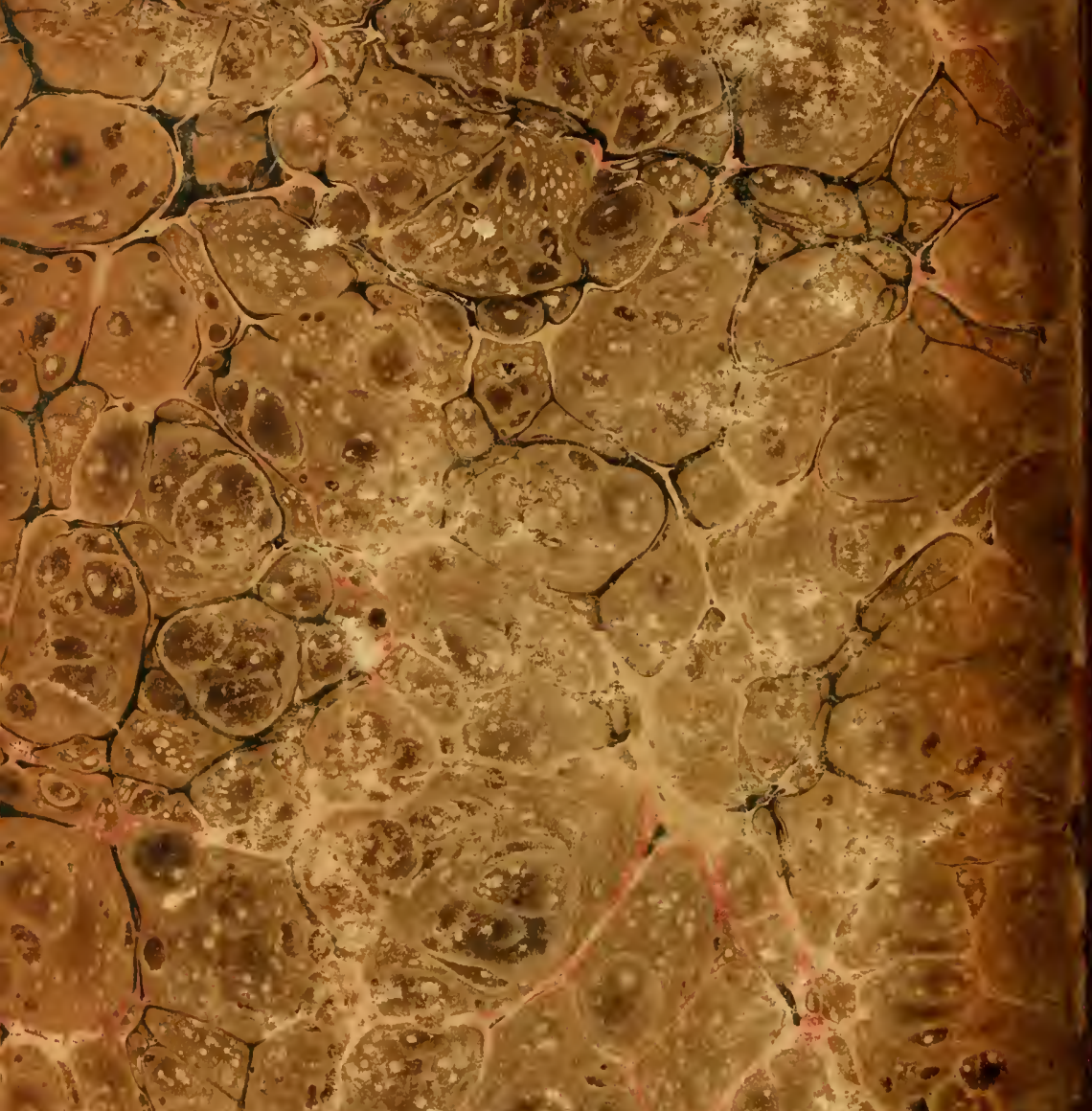

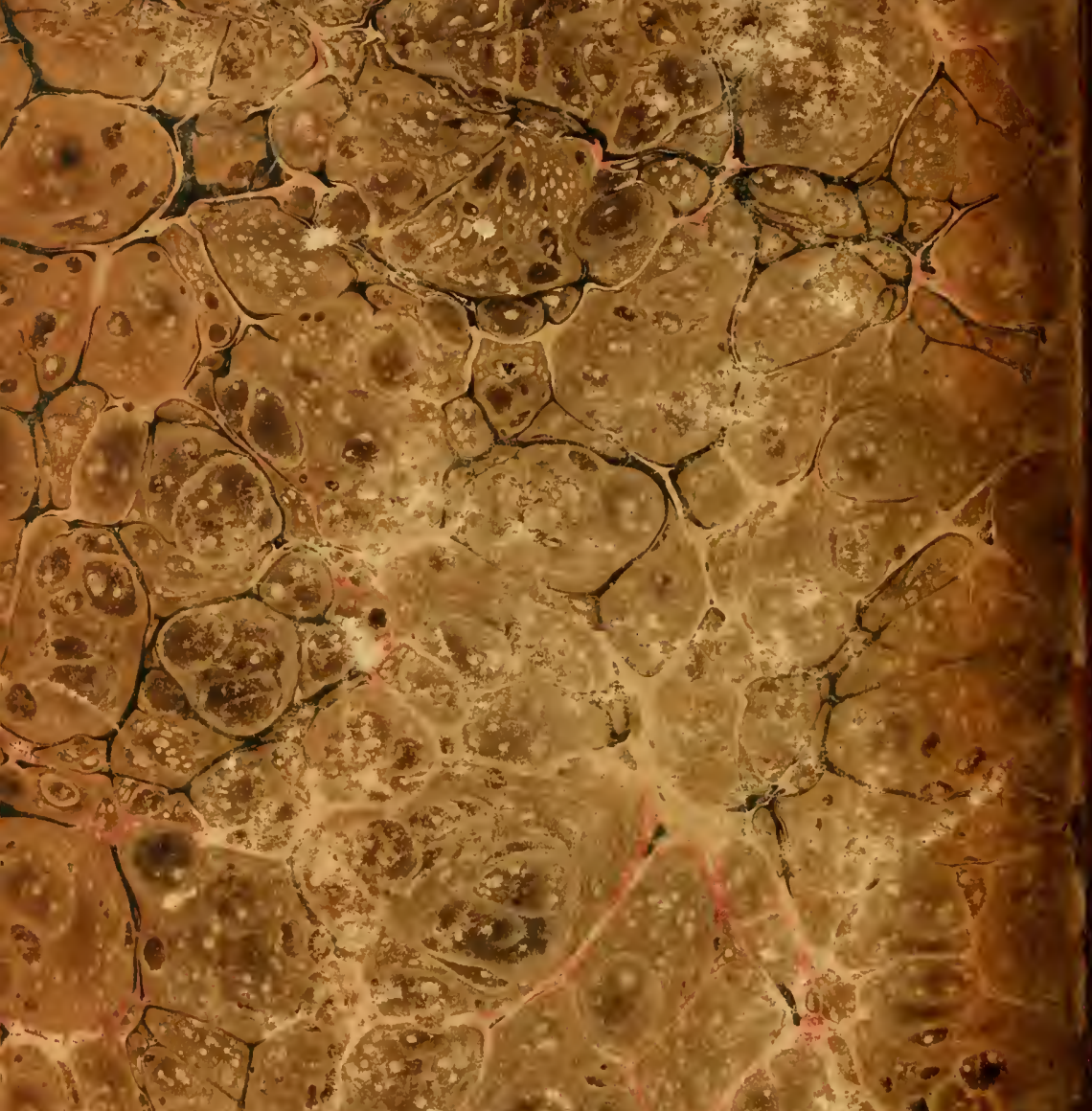

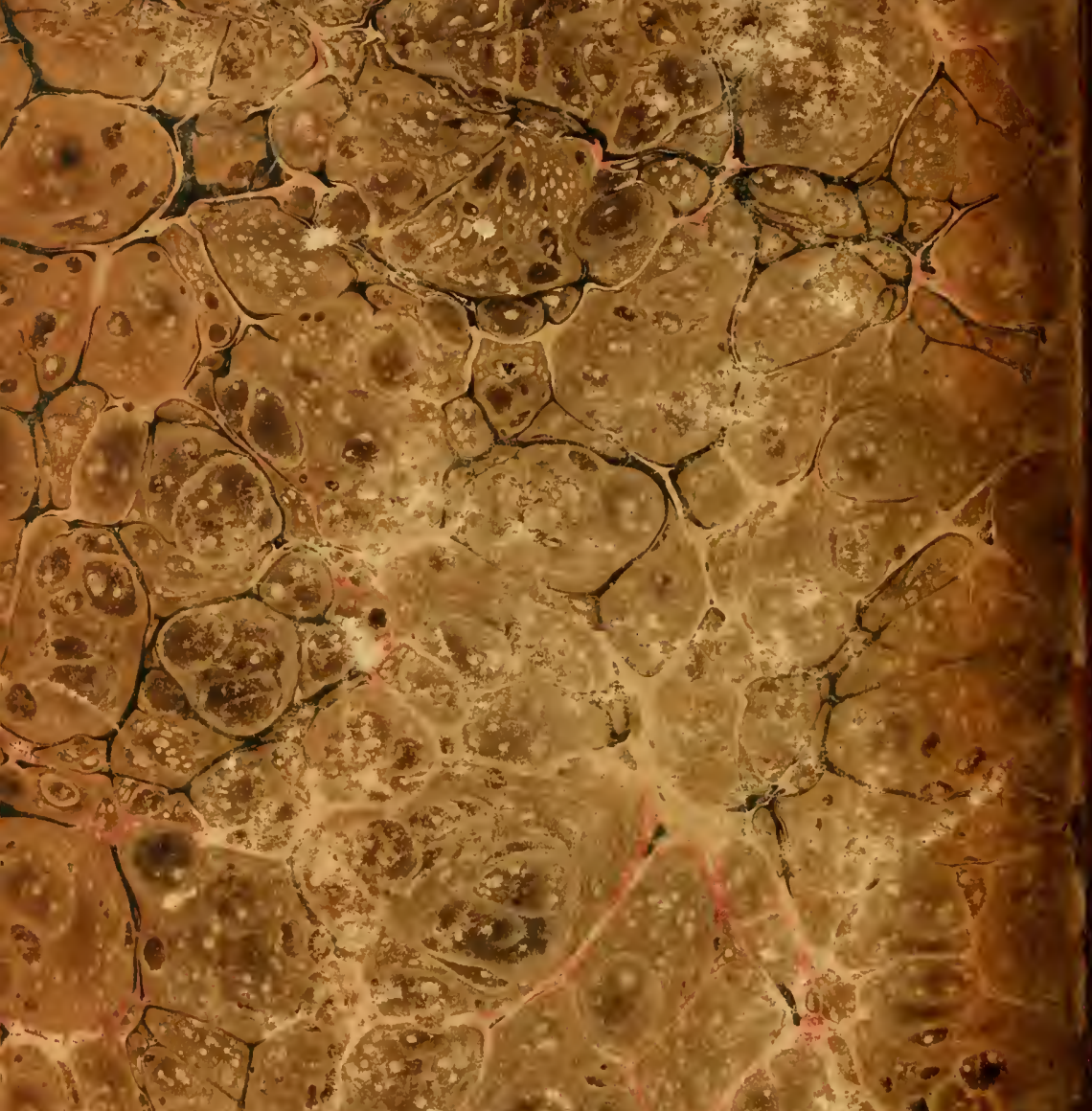

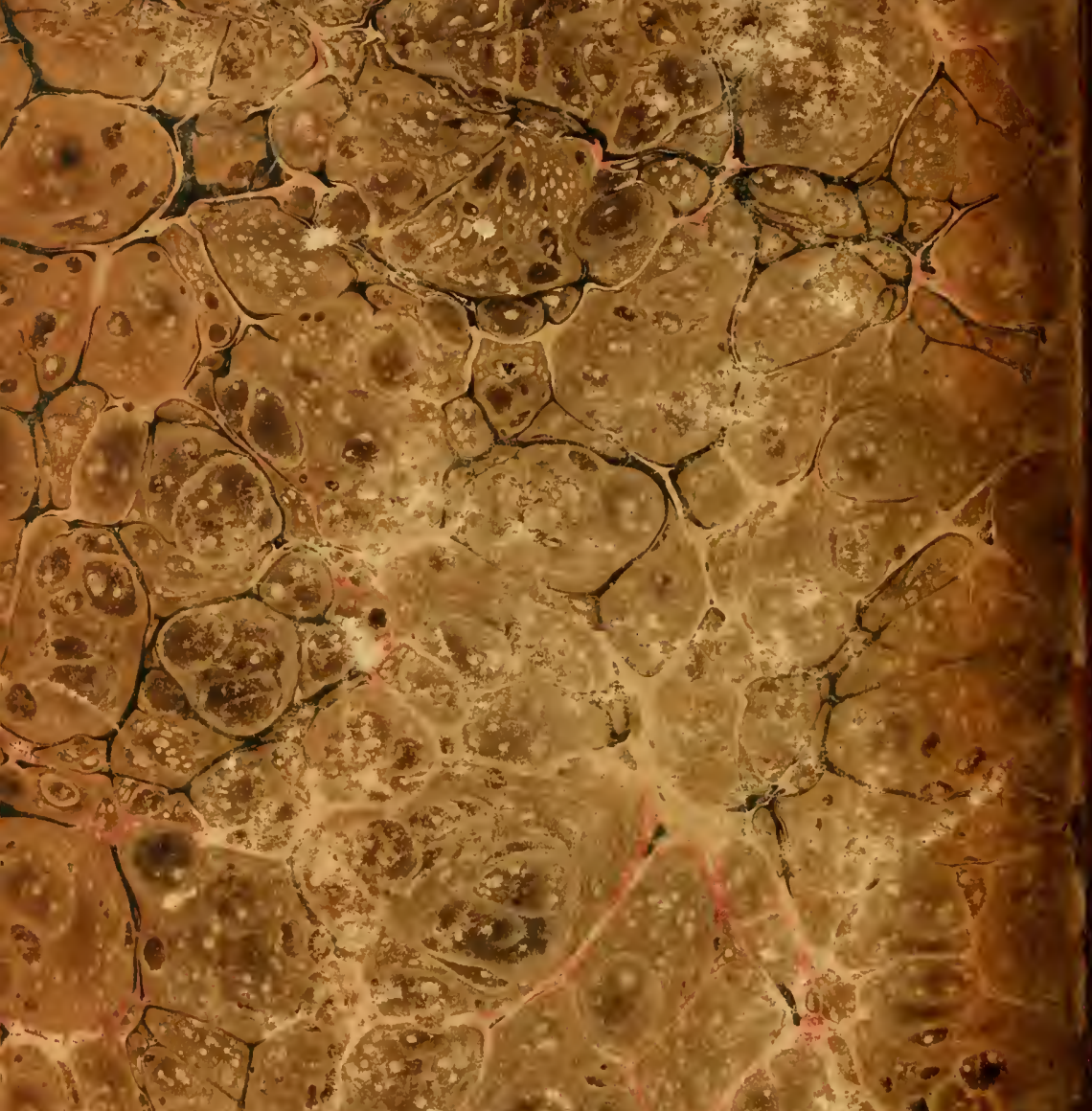

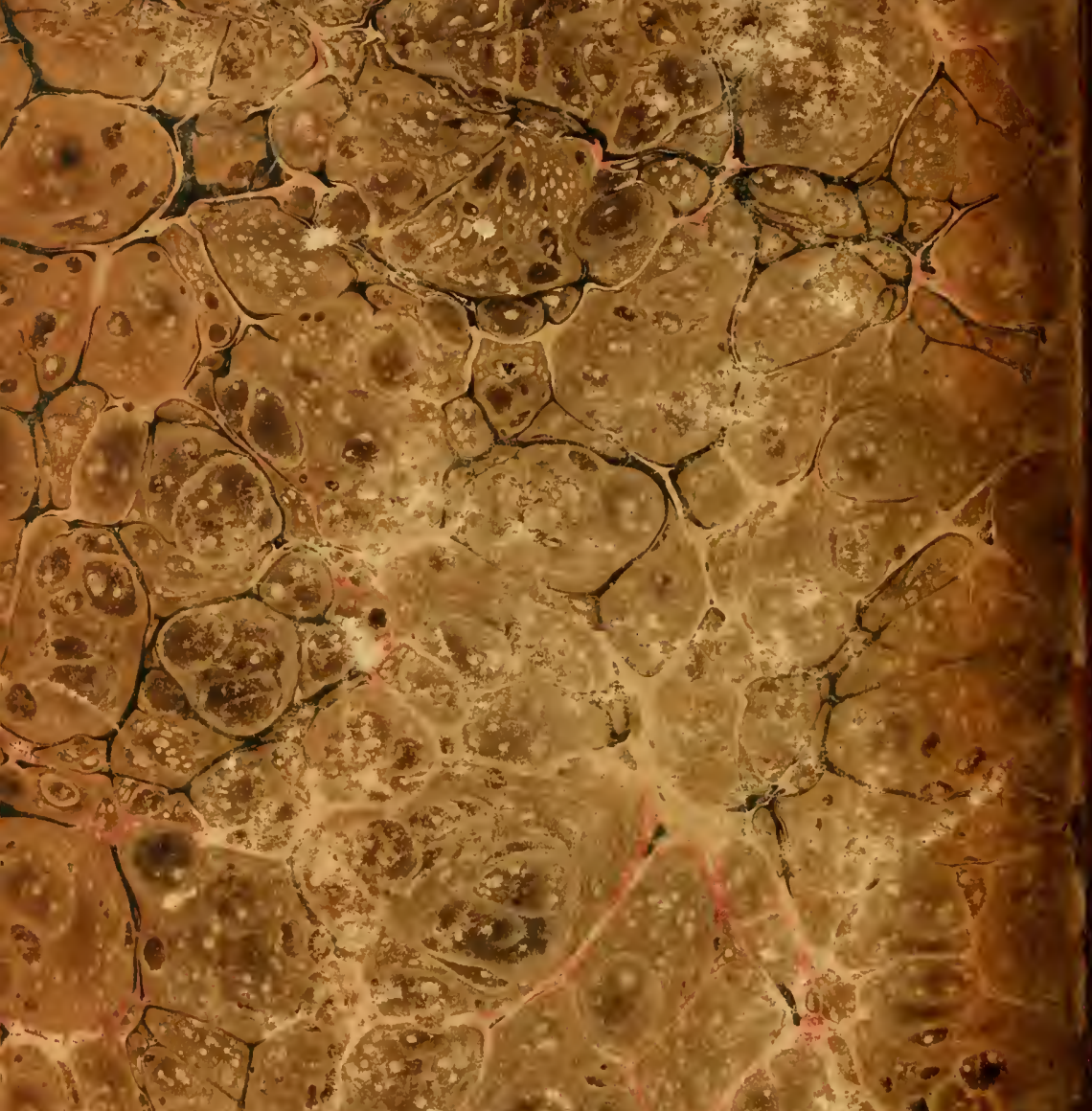

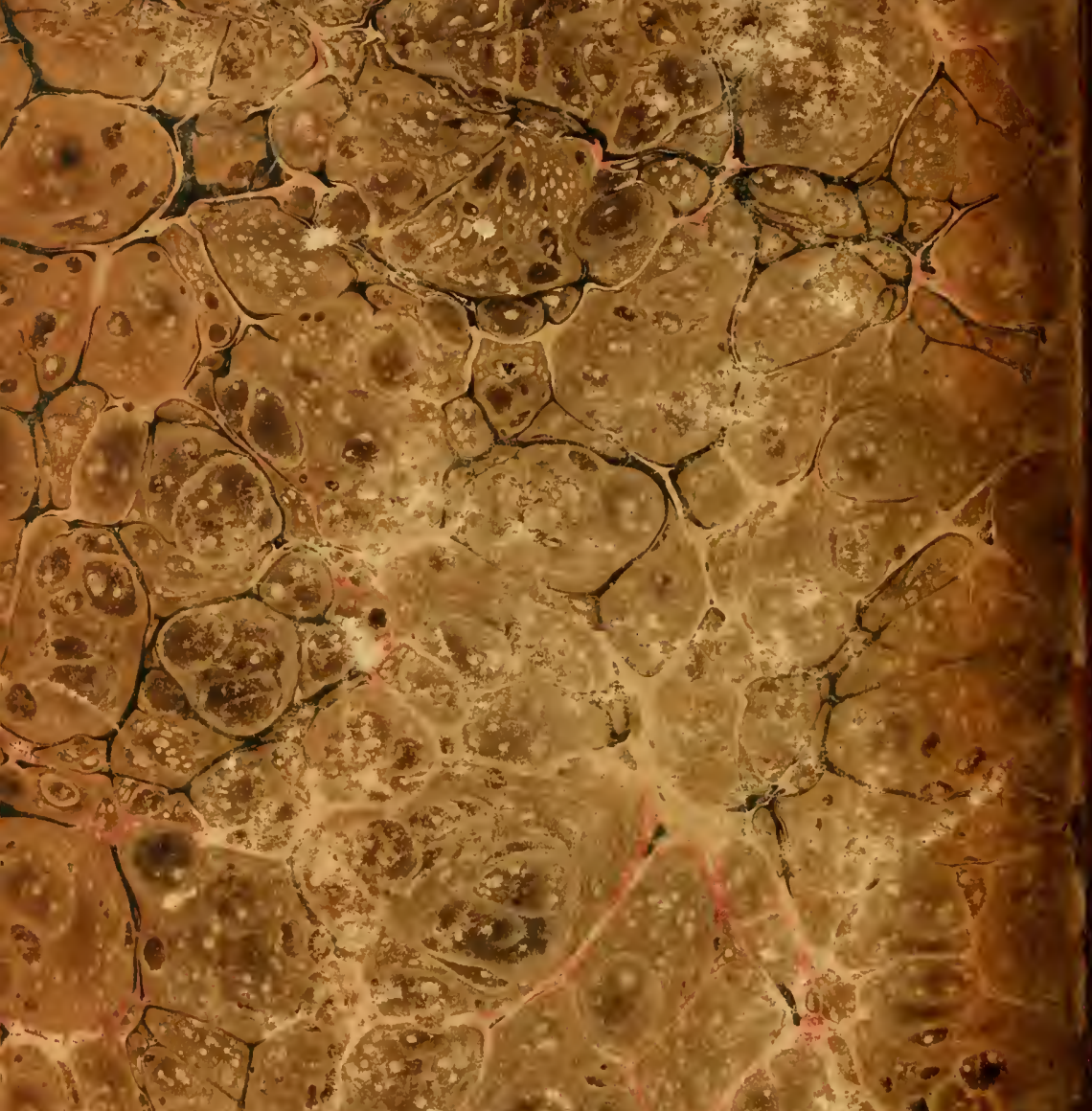

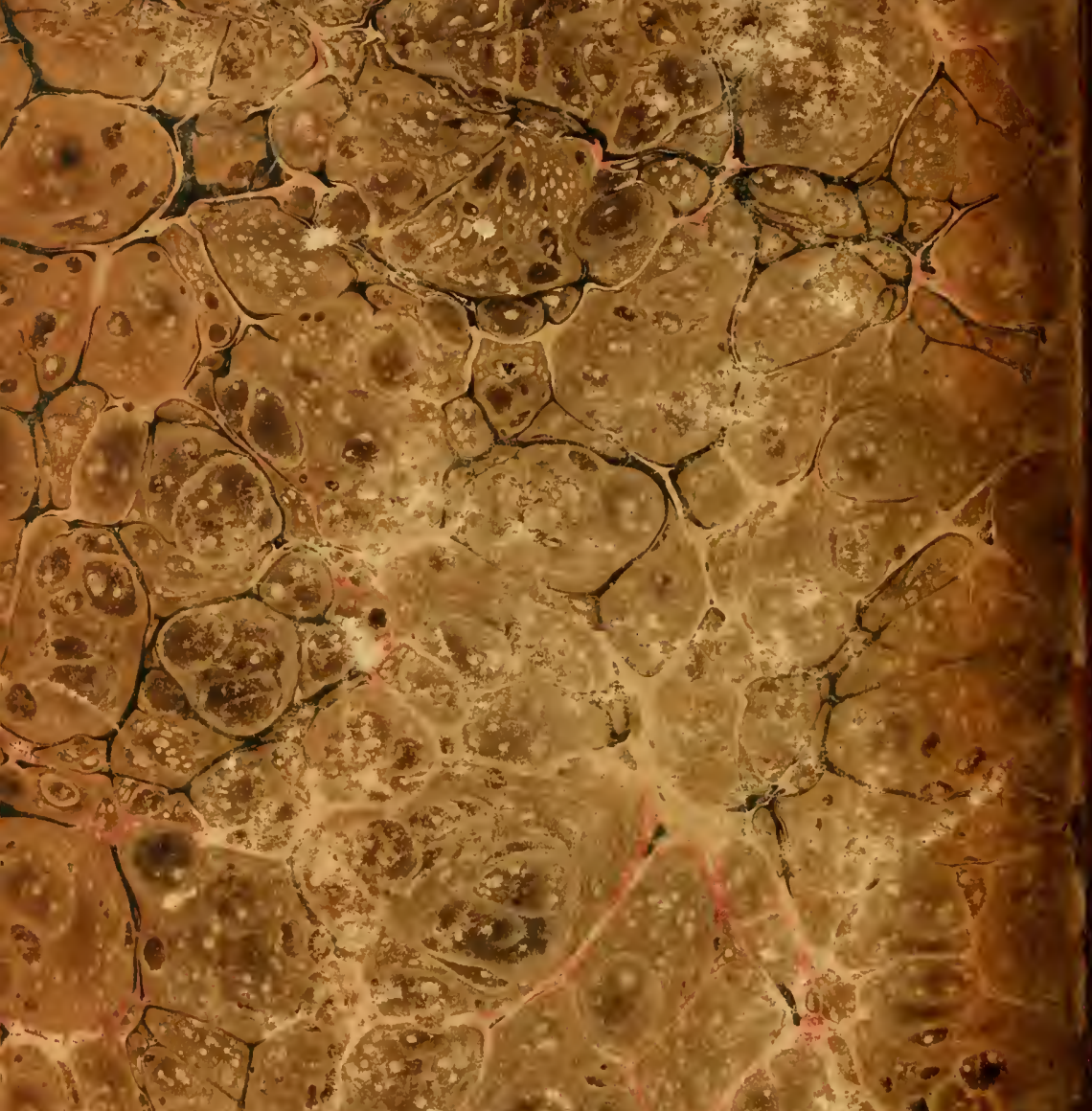
1

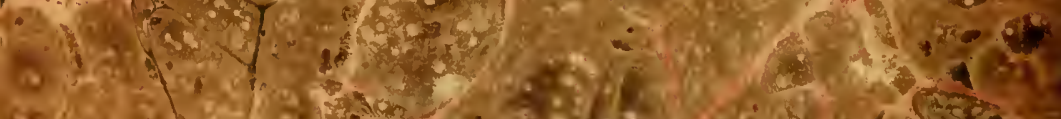

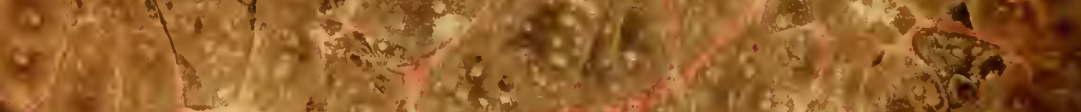

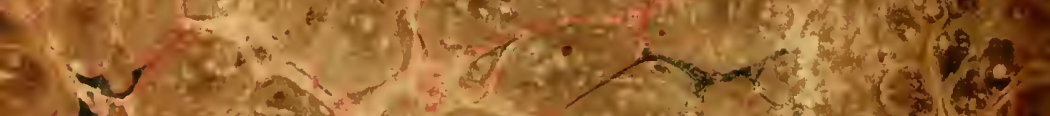

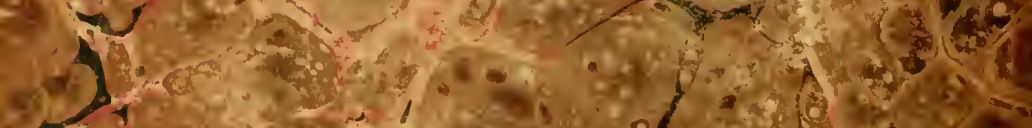

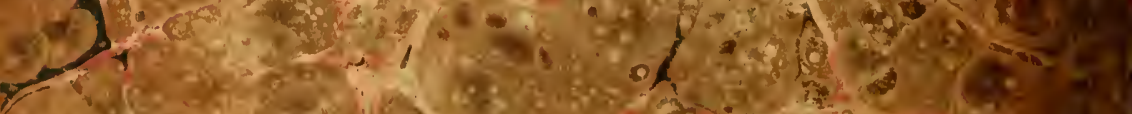
(5) (5) 